\title{
GEOTHERMAL ENERGY RESOURCES
}

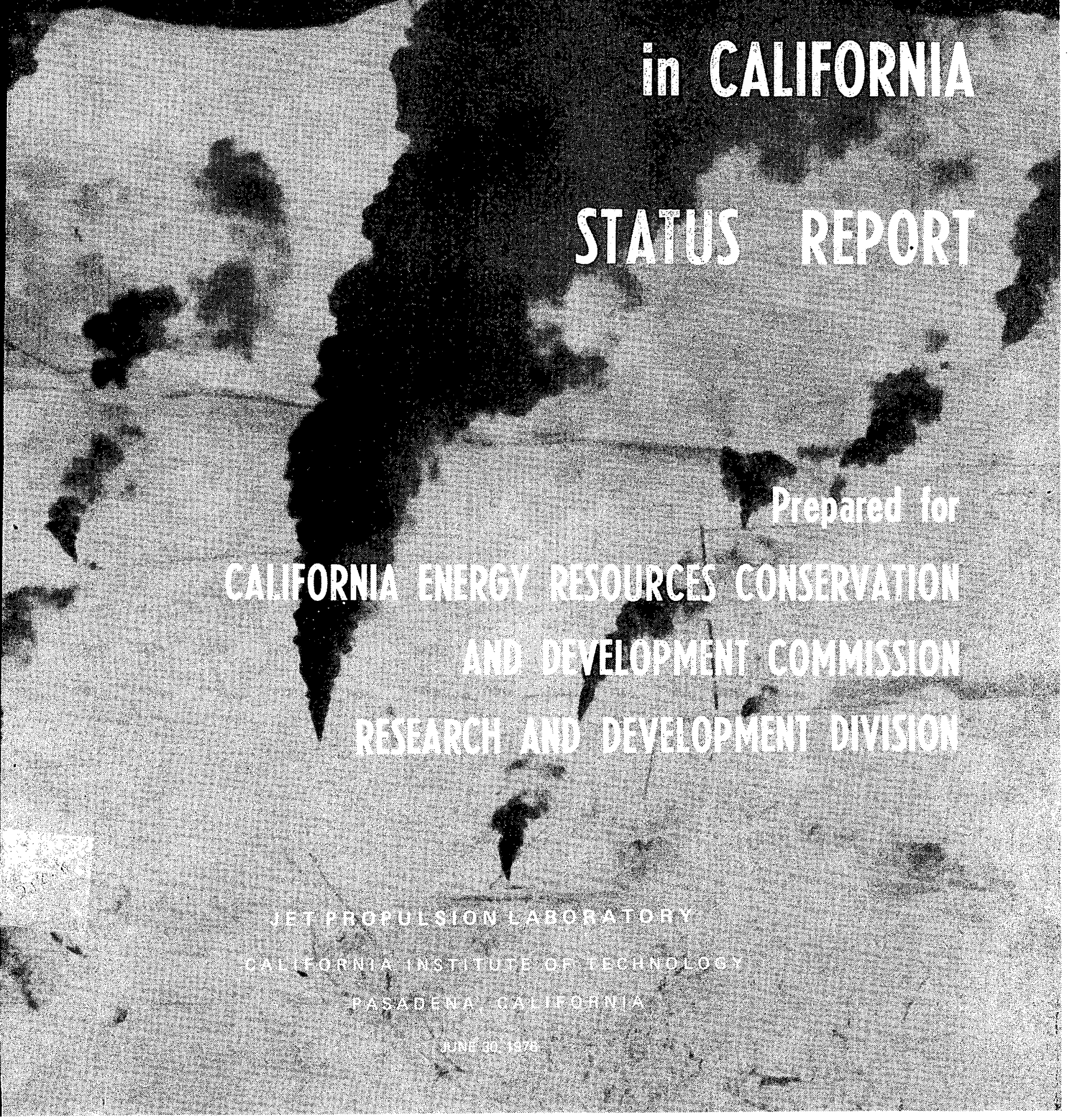




\section{DISCLAIMER}

This report was prepared as an account of work sponsored by an agency of the United States Government. Neither the United States Government nor any agency Thereof, nor any of their employees, makes any warranty, express or implied, or assumes any legal liability or responsibility for the accuracy, completeness, or usefulness of any information, apparatus, product, or process disclosed, or represents that its use would not infringe privately owned rights. Reference herein to any specific commercial product, process, or service by trade name, trademark, manufacturer, or otherwise does not necessarily constitute or imply its endorsement, recommendation, or favoring by the United States Government or any agency thereof. The views and opinions of authors expressed herein do not necessarily state or reflect those of the United States Government or any agency thereof. 


\section{DISCLAIMER}

Portions of this document may be illegible in electronic image products. Images are produced from the best available original document. 


\section{GEOTHERMAL ENERGY}

I N

\section{CALIFORNIA}

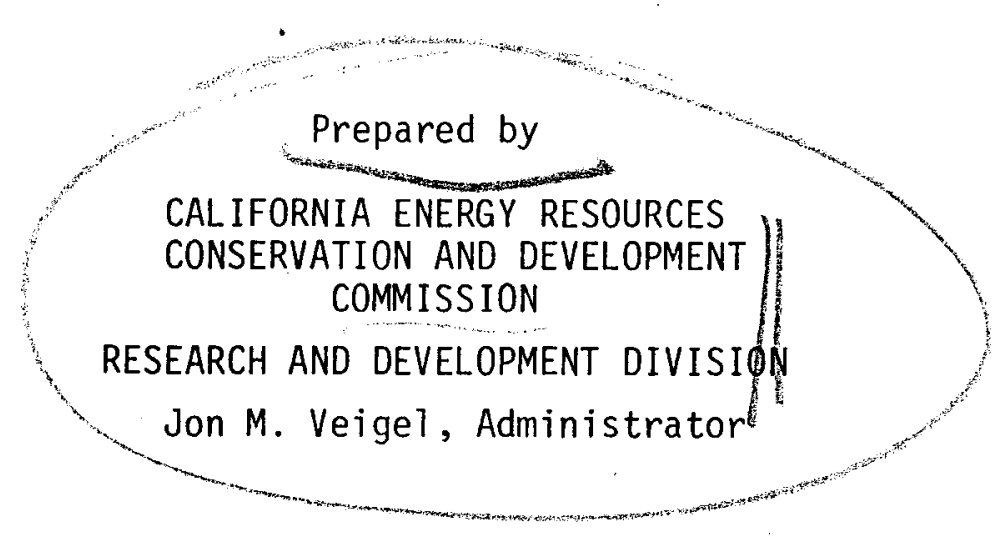

Contract Monitors: Kirk Hall David Hill

This report was prepared by the Jet Propulsion Laboratory of the Catiforna Institute of Technology, Pasadena, California
0. Citron
D. Kerrisk
C. Davis
L. Leibowitz
C. Fredrickson
B. Schulkin
R. Granit
J. Wornack

JPL DOCUMENT 5040-25; REV. A June 1976 

FOREWORD

The potential for electric energy from geothermal resources in California is currently estimated to be equivalent to the output from 14 to 21 large (1000 MW) central station power plants. In addition, since over 30 California cities are located near potential geothermal resources, the nonelectric applications of geothermal heat (industrial, agriculture, space heating, etc.) could be enormous. Therefore, the full scale utilization of geothermal resources would have a major impact upon the energy picture of the State.

This report presents a summary of the existing status of geothermal energy development in the State of California as of the early part of 1976. The report provides data on the extent of the resource base of the state and the present outlook for its utilization. It identifies the existing local, state, and federal laws, rules and regulations governing geothermal energy development and the responsibilities of each of the regulatory agencies involved. It also presents the differences in the development requirements among several counties and between California and its neighboring states. Finally, it describes on-going and planned activities in resource assessment and exploration, utilization, and research and development. Recommendations are not included to avoid the introduction of biases into the data presented.

The draft of this report is in current use by the Energy Commission staff as a source of background data needed to facilitate geothermal planning and development in the state. The Commission recognizes that others will find this compilation of information useful and has authorized its publication to make it available to individuals, conservation groups, industry, communities, counties and other governmental agencies. 


\section{ACKNOWLEDGEMENT}

This report was prepared by the Jet Propulsion Laboratory of the California Institute of Technology, Pasadena, California under contract to the Research and Development Division of the California Energy Resources Conservation and Development Division. Many individuals in government (local, state and federal), industry and the public sector were most helpful in providing data to JPL and also in reviewing the completed document. Their support is greatfully acknowledged. 


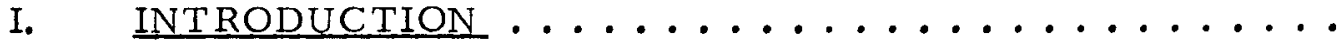

II. CALIFORNIA'S GEOTHERMAL RESOURCE BASE .... $2-1$

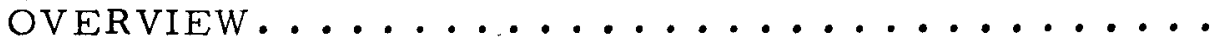

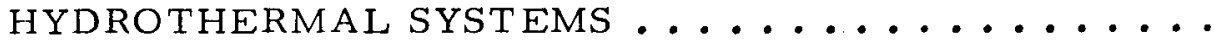

ESTIMATED POTENTIAL OF IDENTIFIED

HYDROTHERMAL RESOURCES ...........

REGIONAL HYDROTHERMAL RESOURCE

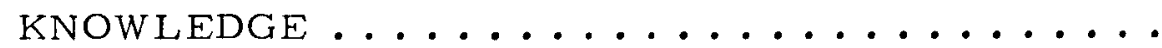

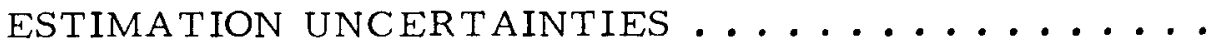

UNDISCOVERED HYDROTHERMAL RESOURCE

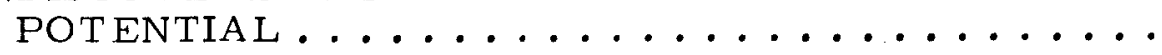

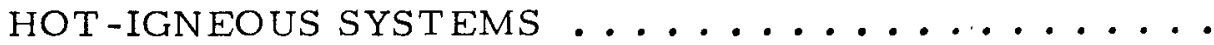

CONDUCTION - DOMINATED AND GEOPRESSURED

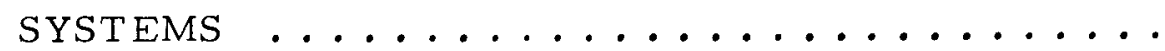

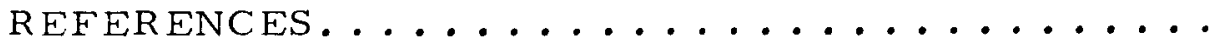

III. PRESENT PLANS OF UTILIZATION OF

GEOTHERMAL ENERGY .............. UTILIZATION BY ELECTRIC UTILITIES -

OVERVIEW $\ldots \ldots \ldots \ldots \ldots \ldots$

PACIFIC GAS AND ELECTRIC COMPANY ........

Present Plans for Additional Generating

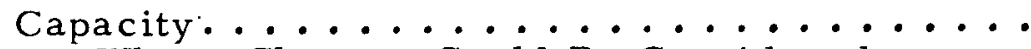

Areas Where Changes Could Be Considered .....

Preconditions for Commitment to

Additional Geothermal Energy .........

SOUTHERN CALIFORNIA EDISON COMPANY.......

Present Plans for Additional Generating

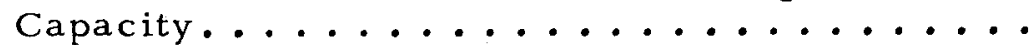

Areas Where Changes Could Be Considered .....

Preconditions for Commitment to

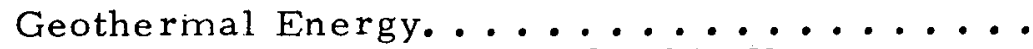

SAN DIEGO GAS AND ELECTRIC COMPANY ......

Present Plans for Additional Generating

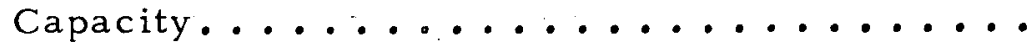

Areas Where Changes Could Be Considered ....

Preconditions for Commitment to

Geothermal Energy .............

CALIFORNIA DEPARTMENT OF WATER

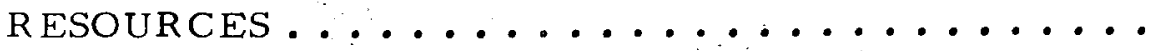

Present Plans for Additional Generating

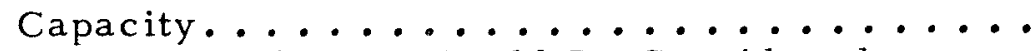

Areas Where Changes Could Be Considered .....

Preconditions for Commitment to

Geothermal Energy ............. 


\section{CONTENTS (Contd)}

NORTHERN CALIFORNIA POWER AGENCY .......

Page

Present Plans for Additional Generating

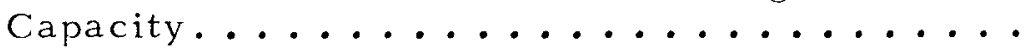

Areas Where Changes Could Be Considered .....

Preconditions for Commitment to

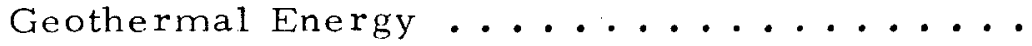

IMPERIAL IRRIGATION DISTRICT ............

Present Plans for Additional Generating

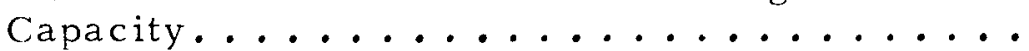

Areas Where Changes Could Be Considered .....

Preconditions to Commitment to

Geothermal Energy ..............

SACRAMENTO MUNICIPAL UTILITIES

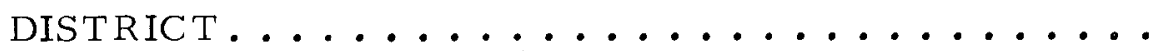

Present Plans for Additional Generating

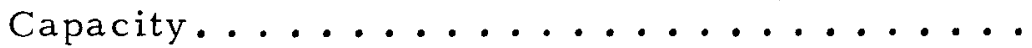

Preconditions for Commitment to

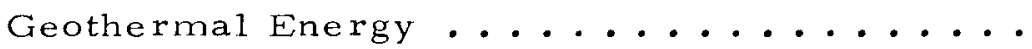

CITY OF BURBANK ...................

Present Plans for Additional Generating

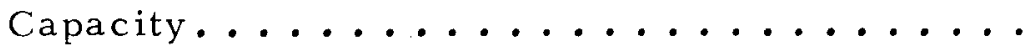

Areas Where Changes Could Be Considered .....

Preconditions for Commitment to

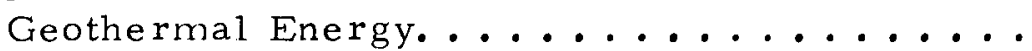

NONELECTRIC UTILIZATION OF

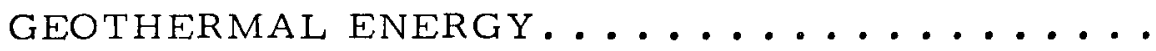

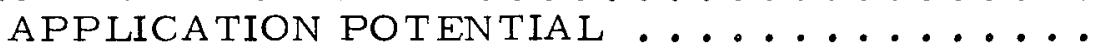

DEVELOPMENT CONSIDERATIONS ........

Industrial Processing ...........

Commercial Space Heating..........

Residential Space Heating ..........

Agribusiness.................

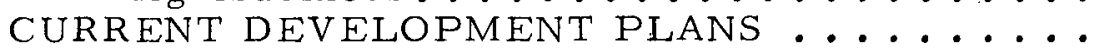

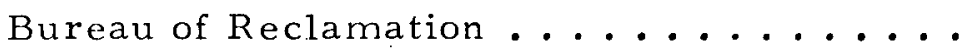

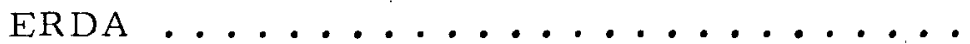

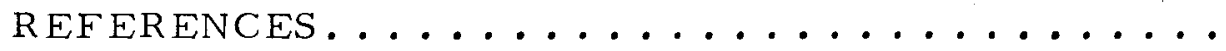

$3-11$

$3-11$

$3-11$

$3-12$

$3-12$

$3-12$

$3-12$

$3-13$

$3-13$

$3-13$

$3-13$

3-14

$3-14$

$3-15$

$3-15$

$3-16$

$3-16$

$3-19$

$3-19$

$3-20$

$3-21$

$3-22$

$3-23$

$3-23$.

$3-24$

$3-24$

IV. THE GEOTHERMAL RESOURCE DEVELOPMENT

PROCESS $\ldots \ldots \ldots \ldots$

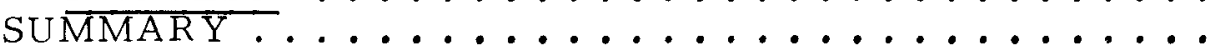
GOVERNANCE OF GEOTHERMAL RESOURCE

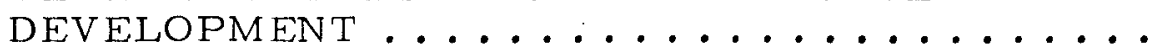

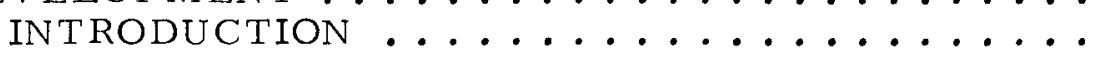

OVERVIEW OF ENERGY REGULATION.......

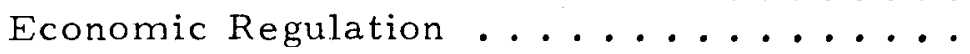

Management of Energy and Land

Resources ................

Protection of Environment, Health,

and Safety

...............

4-1

4-1

4-2

$4-2$

4-4

4- 4

4-7

4-7 
STATE REGULA TORY AGENCIES .........

FEDERAL REGULATORY AGENCIES

LOCAL REGULATORY AND REVIEWING

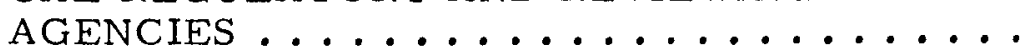

GEOTHERMAL REGULATION IN

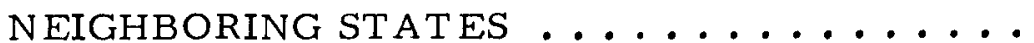

Nevada

$4-12$

Oregon

$4-13$

Arizona

$4-14$

OVERVIEW OF DEVELOPMENT ACTIVITIES

AND ADMINIST RATIVE PROCEDURES .......

$4-14$

GEOTHERMAL DEVELOPMENT ON FEDERAL

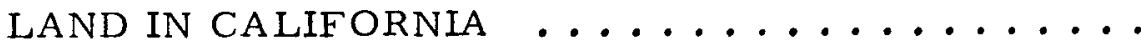

$4-21$

FEDERAL LAND LEASING PROCESS ........

DEVELOPMENT TIMELINES FOR

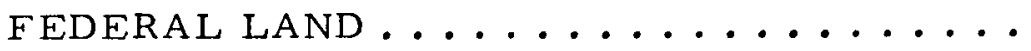
Electric Application ............

$4-22$

Nonelectric Applications ...........

$4-22$

$4-26$

FEDERAL ADMINISTRATIVE PROCESSING

TIME REQUIREMENTS............. Electric Application .............

Nonelectric Applications ............

PRIVATE LANDS IN CALIFORNIA ..........

STATE AND PRIVATE LAND LEASING

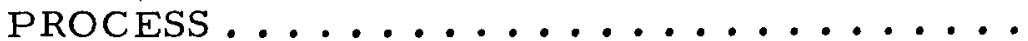

DEVELOPMENT TIMELINES FOR STATE

AND PRIVATE LAND .............

Electric Applications ...........

Nonelectric Applications ...........

STATE AND LOCAL ADMINISTRATIVE

PROCESSING TIME REQUIREMENTS ......

V. REGIONAL DEVELOPMENT STATUS ........

SUMMARY - DEVELOPMENT STATUS .........

SUMMARY - LEASING STATUS ............

SUMMARY - COUNTY DEVELOPMENT

SUMMARY - PROCEDURAL REQUIREMENTS AND

ENERGY REGULATION. ..............

THE GEYSERS REGION................

REGIONAL OVERVIEW ...............

KGRA DESCRIPTIONS AND RESOURCES

ESTIMATES FOR THE GEYSERS REGION ...

The Geysers-Calistoga KGRA .......

Knoxville KGRA..............

Little Horse Mountain KGRA ........

Lovelady Ridge KGRA............ 
CONTENTS (Contd)

Section

$\underline{\text { Page }}$

COUNTY PERSPECTIVES - LAKE, NAPA, SONOMA, MENDOCINO, AND COLUSA:

THE GEYSERS REGION ............

Sonoma County .............

Lake County ................

$5-32$

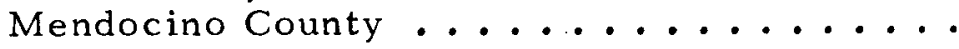

$5-34$

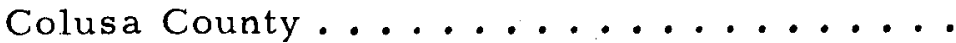

$5-36$

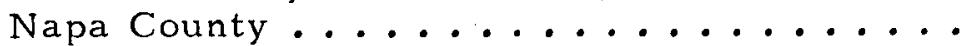

$5-37$

GEOTHERMAL DEVELOPMENT STATUS

IN THE GEYSERS REGION ..........

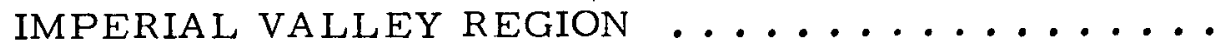

REGIONAL OVERVIEW ...............

$5-40$

$5-45$

KGRA DESCRIPTIONS AND RESOURCE

$5-45$

ESTIMATES FOR THE IMPERIAL

VALLEY REGION ..............

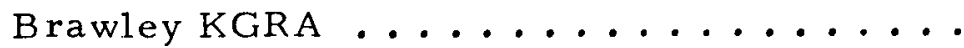

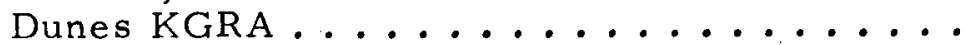

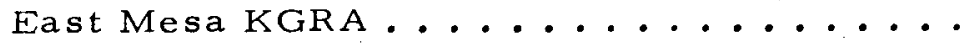

Ford Dry Lake KGRA ............

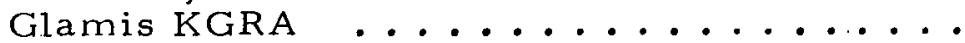

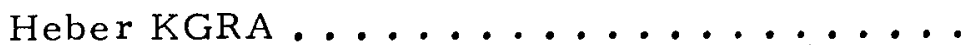

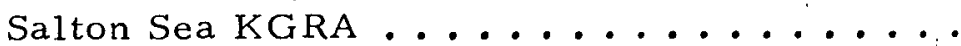

COUNTY PERSPECTIVES: THE IMPERIAL

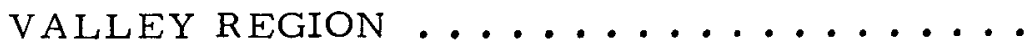

GEOTHERMAL DEVELOPMENT STATUS IN.

THE IMPERIAL VALLEY REGION .......

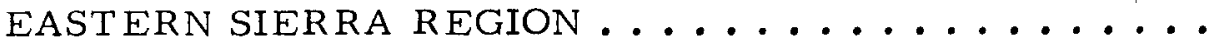

REGIONAL OVERVIEW ............

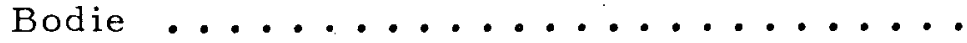

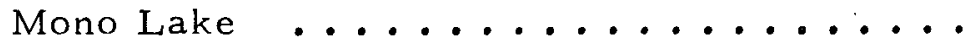

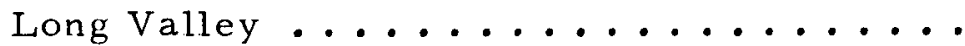

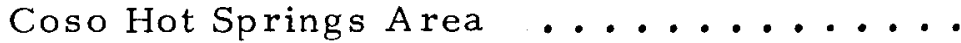

KGRA DESCRIPTIONS AND RESOURCE

ESTIMATES FOR THE EASTERN

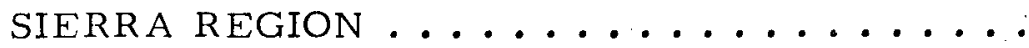

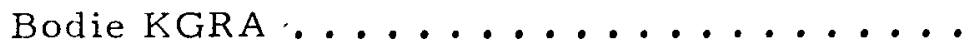

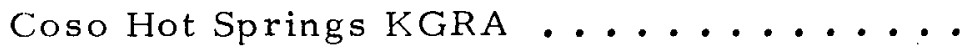

Mono-Long Valley KGRA ..........

Randsburg KGRA ..............

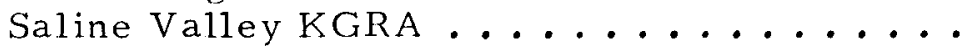

$5-50$

$5-50$

$5-51$

$5-52$

$5-52$

$5-52$

$5-52$

5- 53

5-53

$5-59$

$5-63$

$5-63$

5-63

$5-63$

$5-71$

5-73

5-74

$5-75$

$5-75$

5-76

5-77

5-77

COUNT Y PERSPECTIVES - INYO AND MONO

COUNTIES: THE EASTERN SIERRA

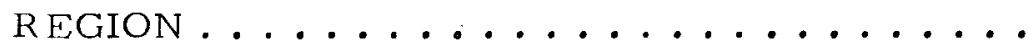

GEOTHERMAL DEVELOPMENT STATUS IN 
CONTENTS (Contd)

Section

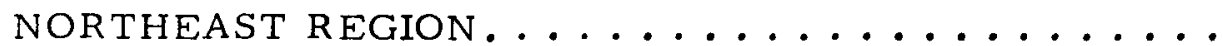

Page

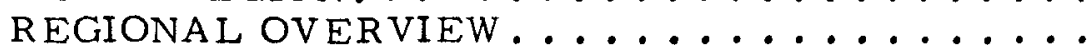

$5-85$

Lake City-Surprise Valley and Glass

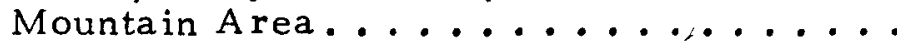

Lassen And Wendel-Amedee Area.......

Beckwourth Peak Area............

KGRA DESCRIPTIONS AND RESOURCE

$5-85$

$5-85$

$5-93$

$5-94$

ESTIMATES FOR THE NORTHEAST

REGION ..................... Beckwourth Peak KGRA ...........

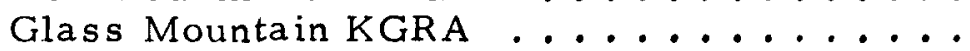

Lake City-Surprise Valley KGRA .......

Lassen KGRA ................

Wendel-Amedee KGRA

COUNTY PERSPECTIVES - MODOC, LASSEN,

PLUMAS, SISKIYOU, TEHAMA, AND

SHASTA: THE NORTHEAST REGION ......

GEOTHERMAL DEVELOPMENT STATUS IN

THE NORTHEAST REGION ...........

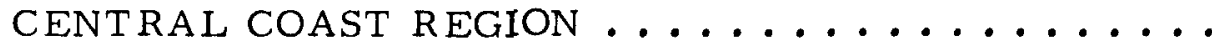

REGIONAL OVERVIEW ..............

Sespe Hot Springs Area...........

Diablo Range Area ..............

KGRA DESCRIPTION AND RESOURCE

ESTIMATES FOR THE CENTRAL

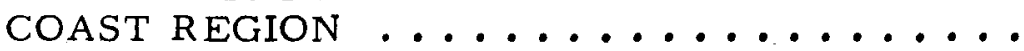

Sespe Hot Springs KGRA ...........

GEOTHERMAL DEVELOPMENT STATUS IN

THE CENTRAL COAST REGION.........

BIBLIOGRAPHY

VI. $\quad$ RESEARCH AND DEVELOPMENT........... EXPLORATION AND ASSESSMENT

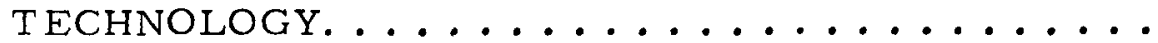

RESOURCE UTILIZATION TECHNOLOGY ......... ENVIRONMENTAL EFFECTS AND

ABATEMENT TECHNOLOGY..............

LEGAL AND INSTITUTIONAL STUDIES ........

PLANNING EFFORTS AND ECONOMIC

ST UDIES

APPENDIX A. GOVERNANCE OF GEOTHERMAL

ENERGY DEVELOPMENT .........

$5-94$

$5-95$

$5-95$

$5-96$

$5-96$

$5-97$

$5-98$

5-104

5-107

5-107

5-107.

5-108

$5-111$

5-111

$5-111$

5-113

6-1

$6-2$

$6-6$

$6-8$

$6-10$

$6-10$

APPENDIX B. ADMINIST RATIVE REQUIREMENTS

A - 1

FOR DEVELOPMENT OF GEO-

THERMAL RESOURCES .........

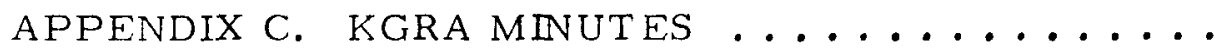

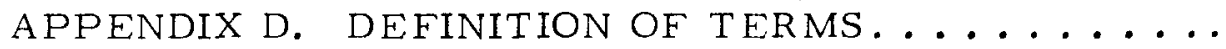

APPENDIX E. LIST OF ABBREVIATIONS ........ 
CONTENTS (Contd)

Figures

$\frac{\text { Page }}{1-3}$
$2-3$
$2-3$
$2-6$
$2-8$
$2-9$
$2-15$
$3-3$

l - l. California's KGRAs ..................

2-1. Identified hydrothermal resources - estimated

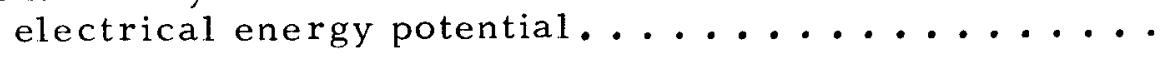

2-2. California's identified hydrothermal resources estimated electrical energy potential, by regions...

2-3. Generalized hydrothermal reservoir ...........

2-4. California's identified hyd rothermal systems .......

2-5. USGS hydrothermal energy potential assessment

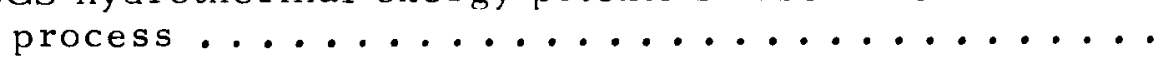

2-6. California's identified volcanic systems ........

3-1. Planned geothermal generating capacity in

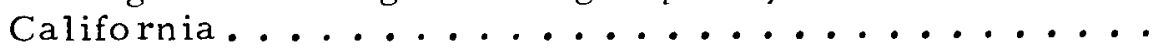

3-2. Cumulative energy use as a function of temperature of heating, shown in relation to the total energy requirements in the United States...........

3-3. Required temperature of geothermal fluids for various nonelectrical applications ..........

4-1. Geothermal plant development model timeline ...... $4-16$

4-2. Activity network for geothermal plant

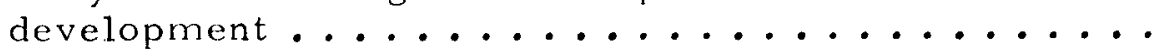

4-3. Estimated timelines for geothermal development on federal KGRA land in California ..........

4-4. Estimated leasing and administrative procedures processing times in development of geothermal resources on federal lands in California (as suming lands a re initially KGRA) .........

4-5. Estimated timelines for geothermal development on state and private KGRA lands in

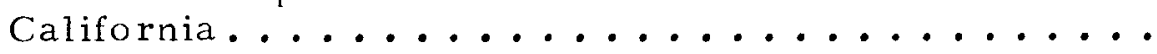

4-6. Estinated leasing and administrative processing times in development of geothermal resources on state or private lands in California .........

5-1. KGRA leasing status (federal land) ............

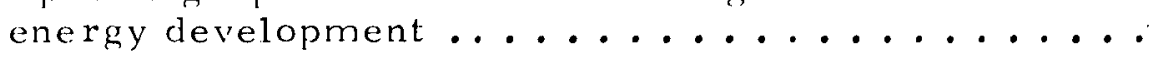

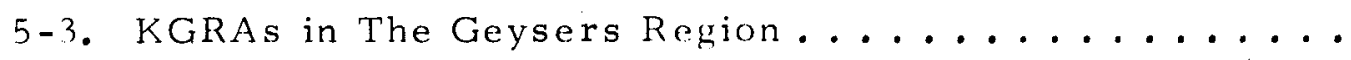

5-4. KGRAs in the Imperial Valley Rogion .......... 
CONTENTS (Contd)

Figures

5-5. Bodie and Mono-Long Valley KGRAs -

Eastern Sierra Region ...............

$\underline{\text { Page }}$

$5-65$

5-6. Saline Valley and Coso Hot Springs KGRAs -

Eastern Sierra Region ..............

$5-67$

5-7. Randsburg KGRA - Eastern Sierra Region ........

5-8. Lake City-Surprise Valley and Glass Mountain KGRAs .................

5-9. Lassen and Wendel-Amedee KGRAs -

Northeast Region .................

5-10. Beckwourth Peak KGRA - Northeast Region ........

5-11. Sespe Hot Springs KGRA - Central Coast Region ......

Tables

1 - 1. KGRA data, by resource region .............

2-1. Heat content of California's resource base (heat in ground above $15^{\circ} \mathrm{C}$ without regard to recove rability) .................

2-2. California KGRAs with identified electrical

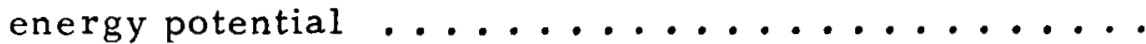

2-3. Identified potential of geothermal resource areas .....

4-1. Public agencies involved in the geothermal resource development process .............

4-2. Public agency responsibilities in the geothermal resource development process .............

$$
4-5
$$

4-3. Overview comparison of geothermal development administrative procedures in the State of

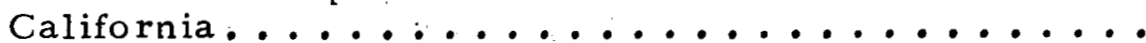

4-4. Timebar estimates assumed in federal-land geothermal plant development timeline (Fig. 4-3) (times a re not cumulative) .........

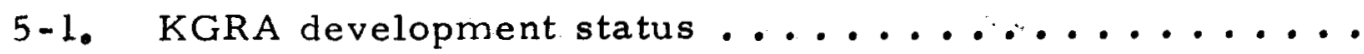

5-2. Summary of drilling operations, by regions ........ $5-3$

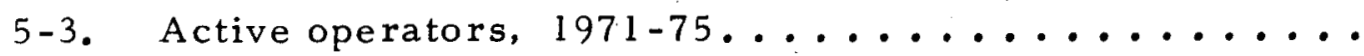
$5-4$

5-4. KGRA land classification (January 31,1976$) \ldots \ldots \ldots$ $5-6$

5-5. Competitive geothermal lease sale summary (January 31,1976$) \ldots \ldots \ldots \ldots \ldots$ 


\section{CONTENTS (Contd)}

Tables

Page

5-6. Tentative KGRA (competitive) lease sale schedule, as of March 1976 (BLM-

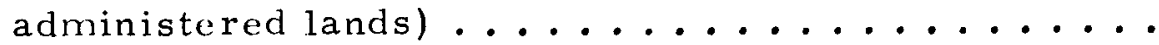

5-7. Tentative noncompetitive leasing schedule

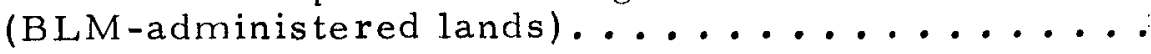

5-8. State lands within potential geothermal areas -

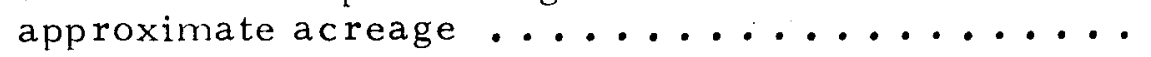

5-9. Geothermal wells summary, as of Dec. 15,

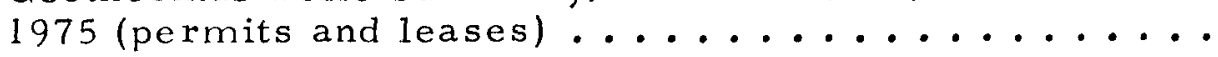

5-10. Use permit/EIR times for final decisions ........

5-11. Estimated energy potential, The Geysers

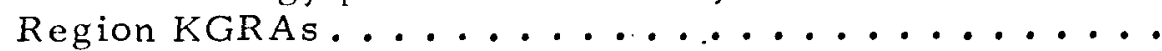

5-12. Use permit requirements, The Geysers Region Sonoma, Lake, Mendocino, Napa, and

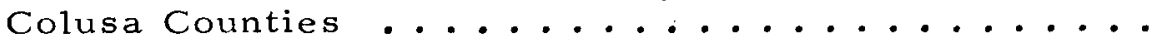

5-13. EIR requirements, The Geysers Region Sonoma, Lake, Mendocino, Napa, and

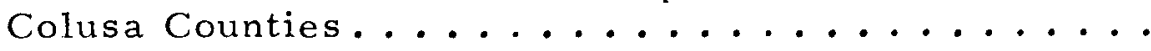

5-14. Energy regulations, The Geysers Region -

Sonoma, Lake, Mendocino, Napa, and

Colusa Counties..................

5-15. Wells drilled, The Geysers Region, 1971-75 ......

5-16. Estimated energy potential, Imperial Valley

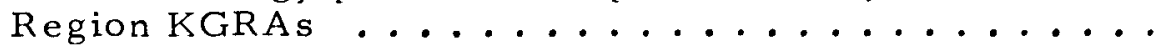

5-17. Use permit and EIR requirements, Imperial

Valley Region - Imperial County............

5-18. Energy regulations, Imperial Valley Region -

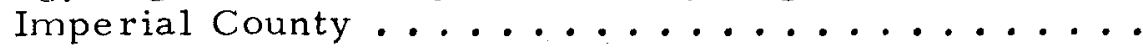

5-19. Wells drilled, Imperial Valley Region, 1971-75 .....

5-20. Estimated energy potential, Eastern Sierra

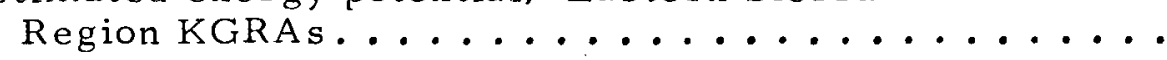

5-21. Use permit and EIR requirements, Eastern Sierra.

Region - Inyo and Mono Counties ...........

5-22. Energy regulations, Eastern Sierra Region-

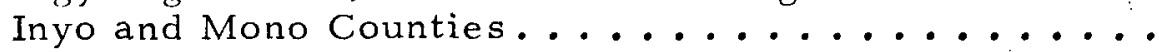

5-23. Estimated energy potential, Northeast Region

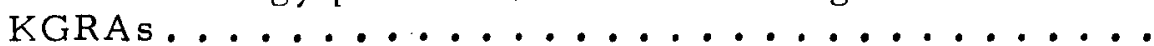




\section{CONTENTS (Contd)}

Tables

5-24. Use permit requirements, Northeast Region Lassen, Modoc, Plumas, Shasta, Siskiyou,

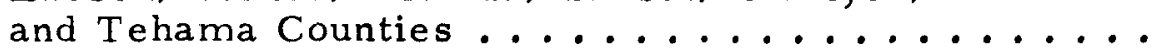

5-25. EIR requirements, Northeast Region - Lassen, Modoc, Plumas, Shasta, Siskiyou, and

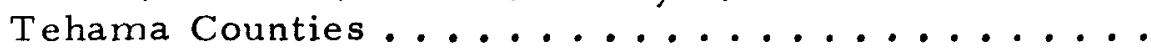

5-26. Energy regulations, Northeast Region-Lassen, Modoc, Plumas, Shasta, Siskiyou, and

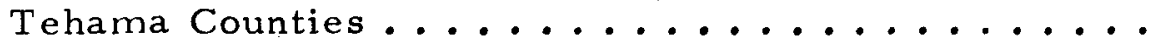

5-27. Wells drilled, Northeast Region, 1971-75 .......

5-28. Estimated energy potential, Central Coast

Region KGRA .................

6-1. Current $R \& D$ programs in geothermal exploration and assessment technology ........

6-2. ERDA R\&D programs for improving geothermal resource extraction technology, as of Feb. I, 1976 .

6-3. ERDA R\&D programs for improvement of

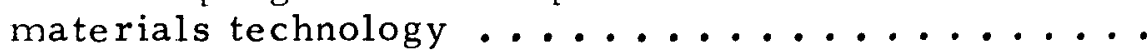

6-4. ERDA R\&D programs for improvement of ........ $6-9$

6-5. $R \& D$ programs to identify, evaluate, and ameliorate the environmental effects of

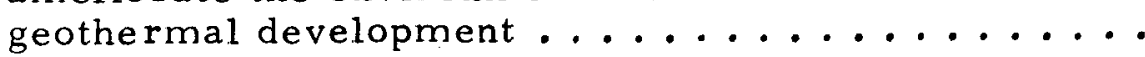

6-6. Additional conversion and materials technology programs ...............

6-7. Additional environmental programs...........

DEFINITION OF TERMS

LIST OF ABBREVIATIONS 

SUMMARY

U. S. Geological Survey (USGS) assessment data on the nation's geothermal resources indicate that California possesses a very large geothermal energy potential. The state's geothermal resources include not only the more familiar hydrothermal systems, typified by those found at The Geysers and in the Imperial Valley, but also hot-igneous (magma and hot dry rock) and conduction-dominated (near-normal-temperature-gradient and perhaps geopressured) systems. The hot-igneous and conduction-dominated systems may eventually prove to contain much greater amounts of heat energy than the hydrothermal systems. However, considerable advancement in technology is required before the potential of the se systems can be harnessed, whereas the technology necessary for the commercial development and utilization of the hydrothermal systems is near at hand. For this reason, most of the geothermal energy development interest and commercial activity in the state is at present focused on the hydrothermal resources. This will probably continue to be the case until more definitive data is available on the extent and location of the hot-igneous and conduction-dominated resources and the technology necessary for their commercial development is demonstrated.

The hydrothermal resources could prove to be a significant energy source for the state and hold great promise for near term development. The USGS estimates that the identified high temperature systems (i.e., systems with temperatures greater than $150^{\circ} \mathrm{C}$ ) in the state are capable of producing the equivalent of $19,200 \mathrm{MW}$ of electrical power for 30 years. In addition, there are many hydrothermal systems in the intermediate temperature range of 90 $150^{\circ} \mathrm{C}$ which could be important in nonelectric applications such as industrial process heating, commercial and residential heating and cooling, and agriculture. The undiscovered hydrothermal resources could be three to four times those already identified in the USGS assessment.

The first uses of geothermal energy in the state were limited to small nonelectric applications such as using thermal springs to heat pools and buildings in the Calistoga-Clear Lake area. The resources were also used to produce 
dry ice and recover calcium chloride in the Imperial Valley and, more recently, to heat greenhouses at Hobo Wells near Susanville. In current development efforts, however, interest is centered on using geothermal energy to produce electric power. The pioneering development of this type in the state, and in the nation, has been at The Geysers in northern California. Commercial development of this relatively unique dry-steam resource has been under way for over 15 years. Over 150 geothermal wells have been drilled in the region. The Pacific Gas and Electric Company currently has an installed electrical capacity of $502 \mathrm{MW}$ at The Geysers, making it the largest geothermal installation in the world. The company has plans to add another $1396 \mathrm{MW}_{\mathrm{e}}$ of capacity by 1985. The California Department of Water Resources and the Northern California Power Agency are also interested in obtaining electric power from The Geysers region.

Geothermal development activity is currently high in the Imperial Valley, both for the generation of electric power and the production of fresh water. The University of California at Riverside has conducted an active exploration program in the region since the 1960 s and close to 60 wells have been drilled. As a result, much data is available on the resource potential, particularly at Brawley, Heber, East Mesa, and the southern end of the Salton Sea. The U.S. Bureau of Reclamation is operating a multiple flashed-steam water desalination pilot plant at East Mesa to investigate the potential of using the geothermal waters of the region as a source of fresh water for the Colorado River. An ERDA field test facility to evaluate developmental components is planned for the Bureau of Reclamation East Mesa site.

The USGS has identified the Mono-Long Valley and Coso Hot Springs areas of the Eastern Sierra Region, and the Lake City-Surprise Valley of the Northeast Region, as having particularly large geothermal energy potentials. However, there has been only limited development activity, primarily leasing and some exploratory drilling. Of the approximately 137 geothermal wells drilled in the state since 1971, only 8 have been located in the Northeast Region, and 2 in the Eastern Sierra Region. Southern California Edison has expressed interest in potential electric and nonelectric geothermal developments in the 
Mammoth area. The U. S. Navy is conducting resource investigations on lands in their jurisdiction at Coso Hot Springs and is interested in the development of a $20 \mathrm{MW}$ e generating plant at that site.

ERDA is supporting a study by the City of Susanville of potential electric and nonelectric applications of the geothermal resources in that area. There has been little activity in the Central Coast Region outside of proposals to evaluate the geothermal resources in the Diablo Range near Santa Clara.

Most of the geothermal development in the state until recently has been restricted to state and private lands. This has been one of the key factors in the limited development to date. However, the passage of the Geothermal Steam Act of 1970 made federal lands available for leasing. Federal lands subject to the Act, and included within "known geothermal resource areas" (KGRAs), are leased competitively, whereas those subject to the Act but outside of KGRAs are subject to noncompetitive leasing. Currently, over 1, 400,000 acres in the state are in designated KGRAs. Of the KGRA lands, 750, 000 acres (53\%) are subject to leasing under the provisions of the Steam Act, the geothermal resources of the Eastern Sierra and the Northeast Regions of the state being predominately on federal lands. The remaining 650,000 acres include state, private, and other lands not subject to the Act. The first lease sales under this act were held in January 1974. As of January 1976, 87, 260 acres of the federal KGRA lands have been offered for leasing, at The Geysers, East Mesa (Imperial Valley), Mono-Long Valley, and Lake City-Surprise Valley. Bids were received on 36, 592 acres and have been accepted. Of the over 900 applications for noncompetitive leases received only three have been approved, on 3, 191 acres in the Lake City-Surprise Valley area; 454 are awaiting action. The remainder have either been withdrawn or rejected. The granting of noncompetitive leases in the state has been slow primarily because of the time and effort required to prepare Environmental Analysis Records. The Bureau of Land Management is stepping up its leasing activities and has established schedules for both competitive lease sales and the processing of noncompetitive lease applications. 
The procedures and regulations which apply to geothermal development in California are the most stringent in the nation and, as a result, introduce considerable delays compared with other states. This is illustrated by the fact that the progress in the issuance of noncompetitive leases is furthe $r$ advanced in other states than in California. Of the 709 noncompetitive leases received in Idaho, 54 have been issued on 91,246 acres. In Nevada 216 out of 1, 182 noncompetitive leases have been issued on 386,795 acres.

The more stringent California requirements stem mainly from the California Environmental Quality Act which requires that all local governments control new development in a manner consistent with the policy guidelines of the Act. All proposed projects, public or private, which are judged to incur potential significant impact to the environment, may not be implemented without preparation and evaluation of an Environmental Impact Report (EIR). The local county) governments are the responsible agencies in issuing the requirement for an EIR for geothermal exploration while the California Energy Resources Conservation and Development Commission is the lead agency for the power plant and related facilities. There are no less than 16 state, 9 federal, and 3 local agencies (in each county) potentially involved in the administration process associated with geothermal energy development in the state. In other states (e.g., Nevada, Arizona, and Oregon) environmental impact reports currently are not required by either local or state authorities, although the matter of environmental quality must be considered. In these other states the approval of a proposed geothermal project is accomplished via relatively simple processes. The delays and uncertainties associated with geothermal development processing in California compared with other states, act as a disincentive to geothermal investment in the California particularly by the more capital-limited exploration companies.

Notwithstanding the current delays associated with development, the outlook for geothermal energy development in the state is very encouraging. Both the interest and investment by private industry and government is increasing. This has been spurred on by the oil embargo of 1973 and by the uncertainties associated with the future of alternative energy sources, particularly nuclear energy. Of the eight utilities contacted in the preparation of this report, four have included geothermal generating capacity in their current 
10-year forecasts. The others are actively considering it. If existing plans are realized, geothermal generating capacity would rise from the present $502 \mathrm{MW}$ to nearly 2300 by 1985 . Early demonstration of the practicability of using the high salinity and/or moderate temperature resources of the Imperial Valley could increase this total by as much as $400 \mathrm{MW}$. In addition to electrical applications there is interest in nonelectric applications, particularly in the Mammoth and Susanville areas.

Government, both state and federal, has established programs to assist environmentally acceptable geothermal development. The Geothermal Energy Research, Development, and Demonstration Act of 1974 (PL 93-410) calls for the national program of coordinated activities to aid in the commercial development of geothermal energy. The objectives and scope of that program are spelled out in ERDA-86, Definition Report: Geothermal Energy Research, Development, and Demonstration Program. The federal budget in geothermal energy has grown from $\$ 9$ million in FY 1974 to an estimated $\$ 45$ million in FY 1977. The California Energy Resources Conservation and Development Commission is very much interested in the evolving role of geothermal energy in the state and is working with ERDA on the definition and implementation of a joint R\&D program to facilitate geothermal development.

Public awareness and interest in the development California's large geothermal potential is growing. Based on interviews in 14 counties with geothermal resources there are also growing concerns over the environmental and socioeconomic consequences of such development. Indications are that geothermal energy development will require the close cooperation of the involved agencies and the affected communities in the satisfactory resolution of these concerns. 


\section{SECTION I}

\section{INTRODUC TION}

There is evidence that all of the three geothermal resource types ${ }^{* k}$ hydrothermal, hot-igneous, conduction-dominated - exist in California in amounts that are of potential economic significance. However, geothermal development activities in the state, as elsewhere, are centered on the hydrothermal resources. The location and extent of many such resources are relatively well known, and a successful extraction technology is available to support commercial development. Commercial electric power from hydrothermal sources is already on line at The Geysers in northern California and Cerro Prieto, Mexico (just south of the Imperial Valley). Although there are indications that the state does possess hot-igneous and conduction-dominated resources in substantial amounts (perhaps far exceeding the hydrothermal resources), both the definitive data on the location and extent of these resource types and the technology to support their

*There are three general classes of geothermal resources:

1. Hydrothermal resources are convective systems of hot water or steam which transfer heat from the deep, hot parts of a thermal anomaly to its nearsurface parts (i.e., less than 3 kilometers). Hydrothermal systems are subdivided into (a) vapor-dominated systems which, at a characteristic temperature of about $240^{\circ} \mathrm{C}$, are capable of producing superheated steam and (b) liquid-dominated systems, which have temperatures ranging from below $90^{\circ} \mathrm{C}$ to above $150^{\circ} \mathrm{C}$ and are capable of producing either a mixture of hot water and vapor, or hot water alone.

2. Hot-igneous resources are associated with igneous-derived thermal anomalies in the upper 10 kilometers of the Earth's crust. Hot-igneous systems are subdivided into (a) hot dry rock systems, which consist of very hot but not molten rocks (i.e., below $650^{\circ} \mathrm{C}$ ) and do not contain sufficient water to be considered hydrothermal convection systems and (b) magma systems consisting of molten rock with temperatures in excess of $\overline{650^{\circ} \mathrm{C}}$.

3. Conduction-dominated resources are comprised of the large heat flow regions underlying most of the United States. In these regions, heat from the deep, hot interior of the Earth and heat of radiogenic origin in the crust are transferred by conduction through solid rock. Temperatures increase with depth and range from $15^{\circ} \mathrm{C}$ to about $300^{\circ} \mathrm{C}$ in the first 10 kilometers below the surface. Geopressured systems are a special category of this resource class. They consist of pressurized water reservoirs within sedimentary basins and are capable of supplying heat and mechanical energy and, in some cases, dissolved methane. 
commercial development are not currently available. A considerable portion of the Federal Government's geothermal energy research program is directed at developing these promising resource types. However, it is not likely that this effort can be brought to fruition in the near future. For these reasons the emphasis of this report is on the current development status of the state's hydrothermal resources.

The centers of hydrothermal development interest in the state are in and around "Known Geothermal Resource Areas" (KGRAs). A KGRA as defined in the rules and regulations (Ref. 1-1) implementing the Geothermal Steam Act of 1970 (PL 91-581), "is an area in which the geology, nearby discoveries, competitive interests, or other indicia would, in the opinion of the Secretary of the Interior, engender a belief in men who are experienced in the subject matter that the prospects for extraction of geothermal steam or associated resources are good enough to warrant expenditures of money for that purpose. "As of January 1976, there were 23 such designated areas in the state (Fig. I-1). For the purposes of this report the KGRAs have been grouped, somewhat arbitrarily, into five resource regions: The Geysers, Imperial Valley, Eastern Sierra, Northeast, and Central Coast. Table $1-1$ gives the KGRAs included in each resource region, the size of éch, and the associated counties.

The report is divided into six sections as follows:

$\begin{array}{ll}\text { Section I } & \text { Introduction } \\ \text { Section II } & \text { California's Geothermal Resource Base } \\ \text { Section III } & \begin{array}{l}\text { Present Plans for the Utilization of } \\ \text { Geothermal Energy }\end{array} \\ \text { Section IV } & \text { The Development and Approval Process } \\ \text { Section V } & \text { Regional Development Status } \\ \text { Section VI } & \text { Research and Development Plans }\end{array}$

Section II, California's Geothermal Resource Base, presents the locations and estimated energy potentials of the state's geothermal resources including not only the hydrothermal systems but also the hot-igneous and conductiondominated systems. An estimate of the energy potential of the undiscovered 


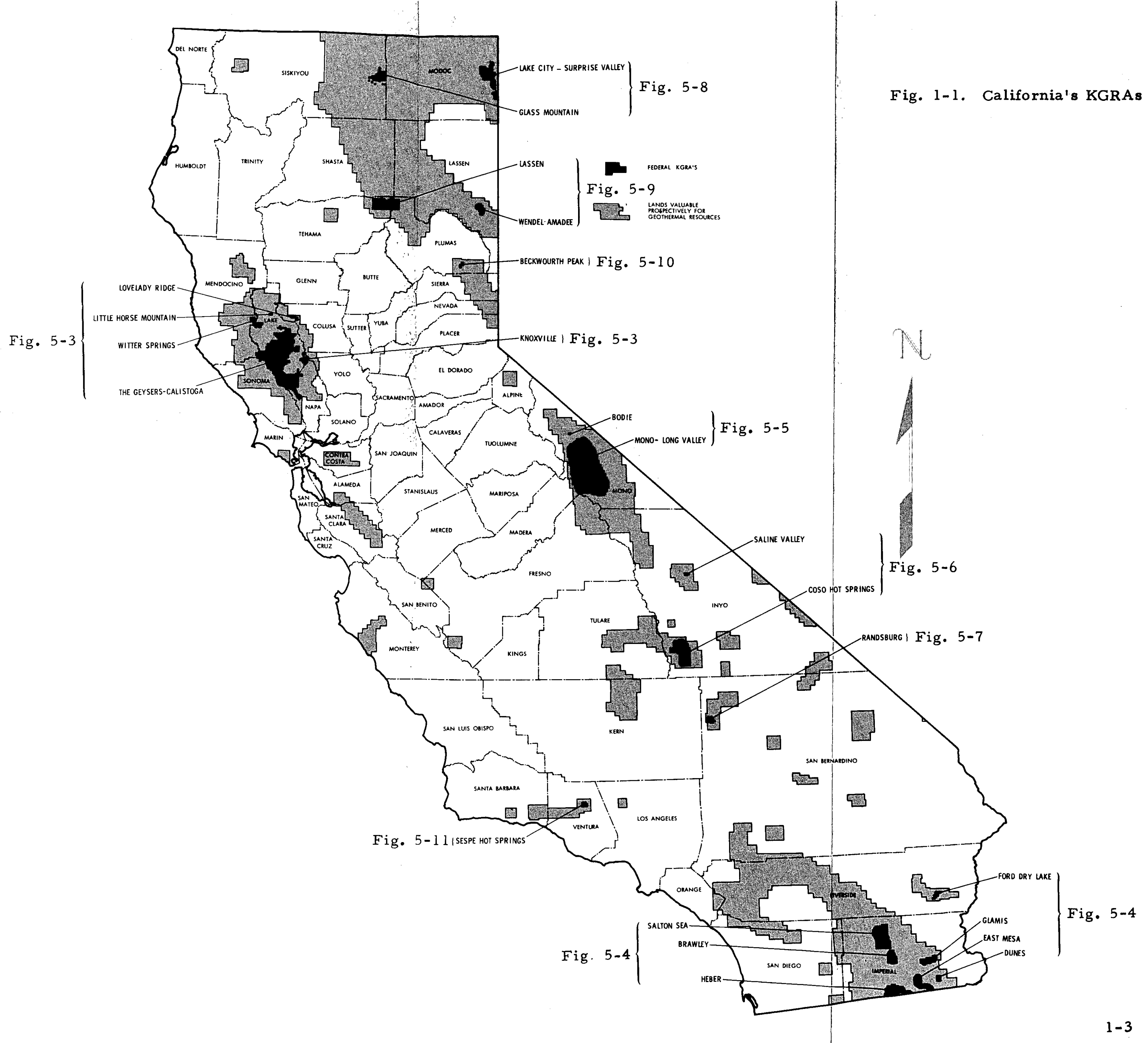



Table 1-1. KGRA data, by resource region

\begin{tabular}{|c|c|c|c|}
\hline Region & KGRA & Acres & County \\
\hline 1. Geysers & $\begin{array}{l}\text { Geysers-Calistoga } \\
\text { Knoxville } \\
\text { Little Horse Mtn. } \\
\text { Lovelady Ridge } \\
\text { Witter Springs }\end{array}$ & $\begin{array}{r}378,687 \\
14,702 \\
1,196 \\
6,879 \\
18,152\end{array}$ & $\begin{array}{l}\text { Lake, Napa, Mendocino, } \\
\text { Sonoma } \\
\text { Lake, Napa, Yolo } \\
\text { Lake } \\
\text { Colusa } \\
\text { Lake, Mendocino }\end{array}$ \\
\hline 2. Imperial Valley & $\begin{array}{l}\text { Brawley } \\
\text { Dunes } \\
\text { East Mesa } \\
\text { Glamis } \\
\text { Heber } \\
\text { Salton Sea } \\
\text { Ford Dry Lake }\end{array}$ & $\begin{array}{r}28,885 \\
7,680 \\
38,365 \\
25,505 \\
58,568 \\
95,824 \\
7,687\end{array}$ & $\begin{array}{l}\text { Imperial } \\
\text { Imperial } \\
\text { Imperial } \\
\text { Imperial } \\
\text { Imperial } \\
\text { Imperial } \\
\text { Riverside }\end{array}$ \\
\hline 3. Eastern Sierra & $\begin{array}{l}\text { Bodie } \\
\text { Coso Hot Springs } \\
\text { Mono-Long Valley } \\
\text { Randsburg } \\
\text { Saline Valley }\end{array}$ & $\begin{array}{r}640 \\
51,760 \\
460,256 \\
12,886 \\
3,200\end{array}$ & $\begin{array}{l}\text { Mono } \\
\text { Inyo } \\
\text { Mono, Madera } \\
\text { San Be rnardino } \\
\text { Inyo }\end{array}$ \\
\hline 4. Northeast & $\begin{array}{l}\text { Beckwourth Peak } \\
\text { Glass Mountain } \\
\text { Lake City-Surprise } \\
\text { Valley } \\
\text { Lassen } \\
\text { Wendel-Amedee }\end{array}$ & $\begin{array}{r}2,558 \\
33,287 \\
66,258 \\
78,642 \\
17,292\end{array}$ & $\begin{array}{l}\text { Plumas } \\
\text { Siskiyou } \\
\text { Modoc } \\
\text { Lassen, Plumas, Shasta, } \\
\text { Tehama } \\
\text { Lassen }\end{array}$ \\
\hline 5. Central Coast & Sespe Hot Springs & 7,134 & Ventura \\
\hline
\end{tabular}


(or unidentified) systems is also given. The resource data in this section is based on the recently published assessment of the nation's geothermal potential by the USGS (Ref. 1-2). An estimate of the energy potential of the $23 \mathrm{KGRAs}$ in the state is made by correlating the identified hydrothermal systems with the identified KGRAs. The estimates by the USGS are subject to large uncertainties because they are based primarily on surface or near surface manifestations and measurements.. These uncertainties are also discussed. Resource data, based on industrial exploration and drilling, does exist in industry and in the files of the state Division of Oil and Gas and the United States Geological Survey. However, these data are considered proprietary by industry, and the associated government records must, by law, be maintained confidential.

Section III, Present Plans for the Utilization of Geothermal Energy, presents the current outlook for the utilization of the hydrothermal resources. It includes the plans of the utilities for adding new generating capacity over the next 20 years and the role of geothermal energy in those plans. The data on electrical utilization was gathered from interviews with those utilities that have been identified as active or interested in geothermal energy. Nonelectric application of geothermal energy in the state is limited primarily to the Susanville area, where ERDA is supporting a study on the total use of geothermal resources, and the Imperial Valley, where the Bureau of Reclamation is conducting desalination research. As a result the data on nonelectric utilization was drawn from previous JPL interviews and analyses (Ref. 1-3) augmented by the data on current research and development activities of the Federal Government.

Section IV. The Development and Approval Process, presents a description of the development and approval process governing geothermal development in the state. It presents an overview of the development process in California, on federal, state, and private lands, and describes the involved agencies and their roles and responsibilities in that process. The key differences between the development in California and neighboring states are identified. The data in this section and the supporting appendixes were drawn from the previous JPL report for NASA (Ref. 1-3) and from discussions with the involved agencies. 
The Governor's Office of Planning and Research and members of the staff of the state Division of Oil and Gas have done considerable research in this area which proved to be extremely helpful.

Section V, Regional Development Status, presents data on the progress of geothermal development in the five resource regions of the state. It includes a description of the resource regions and their associated KGRAs, the perspectives of the counties and regional agencies toward geothermal development, and a summary of the leasing, drilling, and other development activities in each region. Descriptive data on the regions and the KGRAs were drawn from existing reports, which included Environmental Analysis Reports and the "minutes" of the Mineral Land Classification Board Evaluation Committee of the USGS. The state Division of Oil and gas was helpful in providing maps and data on exploration and drilling activities in the state. Data on leasing activities on state and federal lands was provided by the State Lands Commission and the United States Bureau of Land Management. Data on the geothermal leasing of private lands is not as readily accessible as that for state and federal lands. There is no legal requirement that such leases be recorded. Those records that do exist are in the land records of the counties. As an alternative to researching these records, other data sources were used to identify development and activities on private land. These data sources included the records of well drilling permits and operations maintained by the Division of Oil and Gas as well as interviews with the various county planning offices. Information on regional perspectives was also gathered from interviews with county officials and other governmental agencies in each of the regions.

Section VI, Research and Development, presents the research and development activities under way in the nation that could be of assistance to geothermal development activities in the state. The federal government has a large and increasing budget to support geothermal energy development in the nation. The geothermal research and development activities of many of the state's educational institutions are supported by this program. This section summarizes the Federal Government programs as well as those of the California Energy Resources Conservation and Development Commission, the State Lands Commission, and the Electric Power Research Institute. 
REFERENCES

1-1. Geothermal Steam Act of 1970 and Regulations on the Leasing of Geothermal Resources, U.S. Geological Survey, U.S. Department of the Interior, May 1975.

1-2. Assessment of Geothermal Resources of the United States - 1975, Geological Survey Circular 726, U.S. Geological Survey, National Center, Reston, Virginia.

1-3. Program Definition for the Development of Geothermal Energy, Report 5040-6, Jet Propulsion Laboratory, Pasadena, California, August 29, 1975. 
SECTION II

CALIFORNIA'S GEOTHERMAL RESOURCE BASE

\section{OVERVIEW}

The United States Geological Survey recently completed an assessment of the nation's hydrothermal, hot-igneous, and conduction-dominated geothermal resources (Ref. 2-1). The hydrothermal systems included were the high temperature systems (i.e., greater than $150^{\circ} \mathrm{C}$ ) - typified by the vapor-dominated (steam) fields of The Geysers and the hot water systems of the Imperial Valley and the intermediate temperature systems (i.e., 90 to $150^{\circ} \mathrm{C}$ ). The assessment also presented estimates of the energy potential of the hot-igneous (magma and hot dry rock) systems and conduction-dominated systems. This latter category includes both the higher than normal heat flow regions typified by the basin and range provinces of the West and the geopressured systems found primarily along the Gulf Coast of Texas and Louisiana. The USGS report is particularly valuable in that it provides a tabulation and consistent evaluation of the energy content of the identified ${ }^{*}$ geothermal systems of the nation and an estimate of the potential magnitude of undiscovered systems. A summary of the heat content of California's geothermal resources based on the USGS data is given in Table $2-1$.

The energy content of California's geothermal resources is enormous as is evident from Table 2-1. The identified high temperature hydrothermal systems (i.e., those having temperatures over $150^{\circ} \mathrm{C}$ ) are of particular importance to the state because of their potential for near term commercial development for electrical power production. The USGS estimates that the recoverable thermal energy of the identified systems, when converted to electrical energy, could

\footnotetext{
I. e., those geothermal systems tabulated in Ref. 2-1 with identified locations and estimates of reservoir temperature and heat content.
} 
Table 2-1. Heat content of California's geothermal resource base (heat in ground above $15^{\circ} \mathrm{C}$ without regard to recoverability)

\begin{tabular}{|c|c|c|}
\hline \multirow{2}{*}{ Resource Type } & \multicolumn{2}{|c|}{ Energy Content in Quads* } \\
\hline & Identified & Undiscovered \\
\hline \multicolumn{3}{|l|}{ Hydrothermal } \\
\hline Vapor-dominated (steam) & 75 & 75 \\
\hline \multicolumn{3}{|l|}{ Liquid-dominated (hot water) } \\
\hline - High temperature $\left(>150^{\circ} \mathrm{C}\right)$ & 650 & 2000 \\
\hline $\begin{array}{l}\text { Intermediate } \\
\text { temperature }\left(90-150^{\circ} \mathrm{C}\right)\end{array}$ & 30 & 120 \\
\hline Hot-Igneous & 14,700 & 55,000 \\
\hline \multicolumn{3}{|l|}{ Conduction-Dominated } \\
\hline - Near normal gradient & $>635,000$ & 0 \\
\hline - Geopressured & Unknown & Unknown \\
\hline \multicolumn{3}{|c|}{$\begin{array}{l}\text { * quad }=10^{15} \text {. Btu's and is equivalent to approximately } 170 \text { million barrels } \\
\text { of oil or } 50 \text { million short tons of coal. }\end{array}$} \\
\hline
\end{tabular}

provide the equivalent of over $19,000 \mathrm{MW}_{\mathrm{e}}^{\text {(1) }}$ of electrical power for 30 years (Ref. 2-2). As is shown in Fig. 2-1 this is over $70 \%$ of the identified U.S. potential for this resource type and roughly 10 times that of Nevada and Oregon, the states with the next largest identified resources. Figure $2-2$ shows the distribution of this electrical potential in the five resource regions of the state: The Geysers, Imperial Valley, Eastern Sierra, Northeast, and Central Coast. The identified potential of the Eastern Sierra and the Imperial Valley Regions is larger than that of The Geysers; the potentials of the Mono-Long Valley and

(1) Based on considerations of technology and not necessarily economics. 


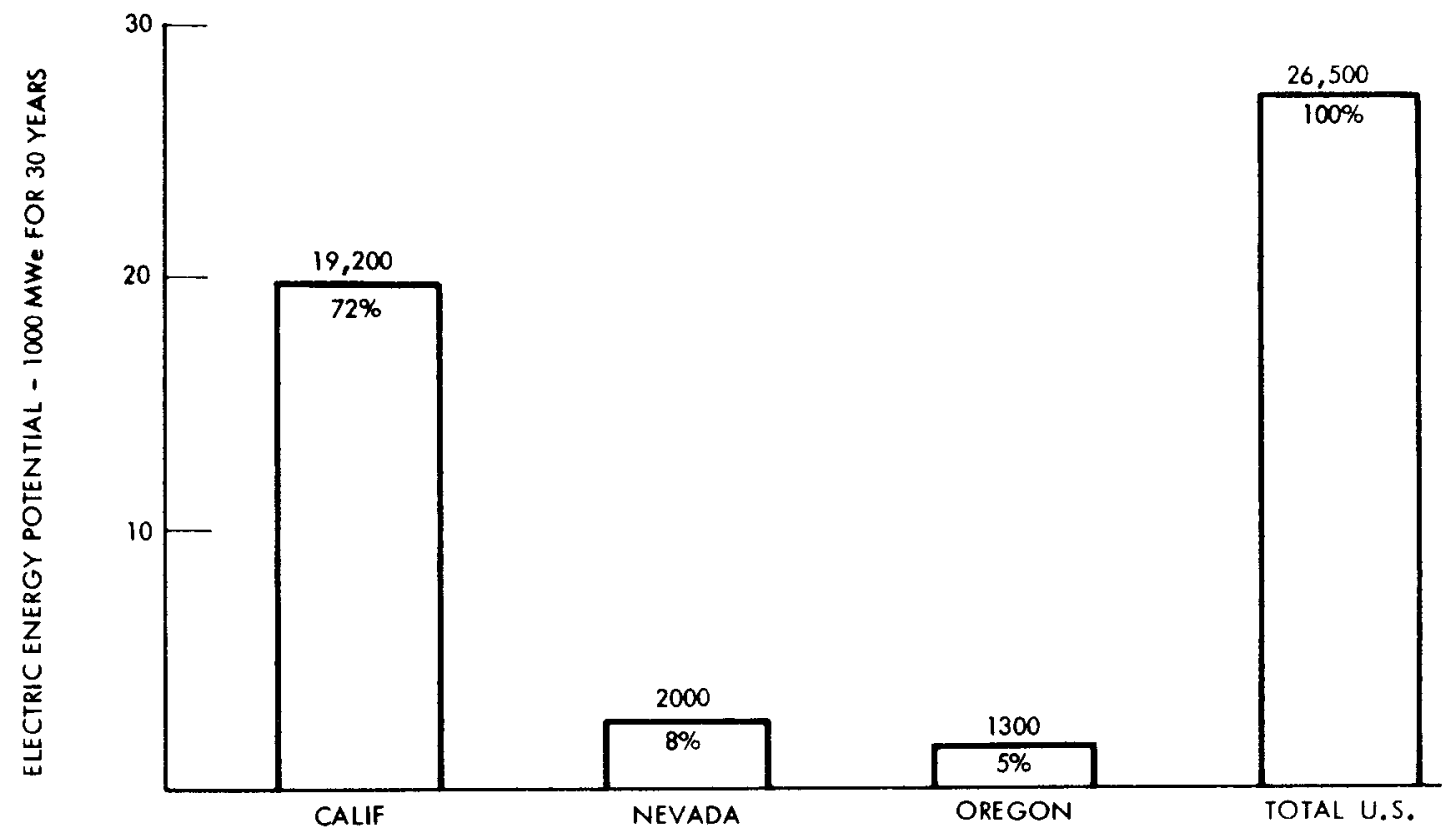

Fig. 2-1. Identified hydrothermal resources estimated electrical energy potential

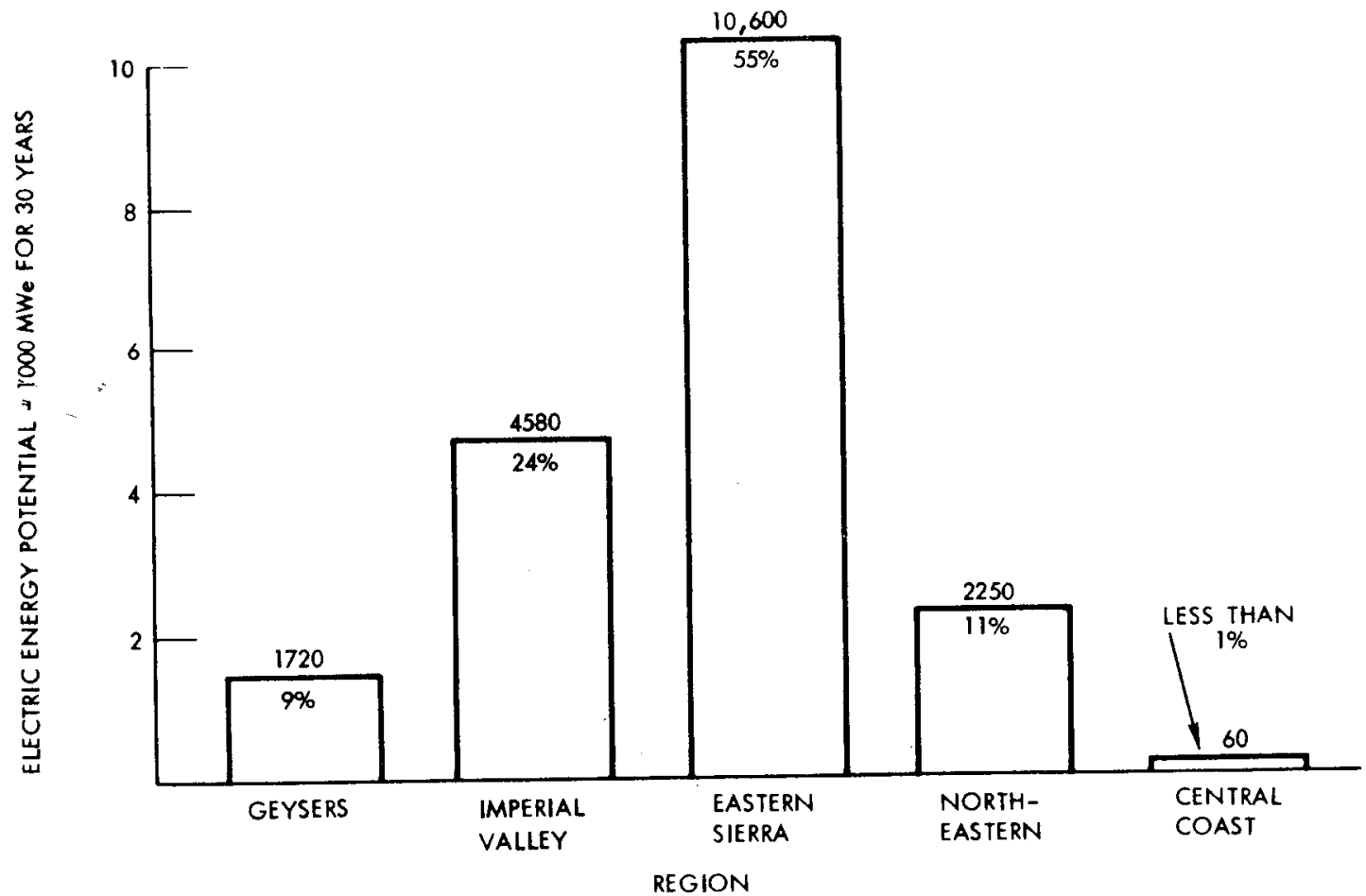

Fig. 2-2. California's identified hydrothermal resources estimated electrical energy potential, by regions 
Coso Hot Springs KGRAs are particularly large. Table $2-2$ lists the nine KGRAs in the state with identified electrical energy potential in the order of that potential. (2)

Table 2-2. California KGRAs with identified electrical energy potential

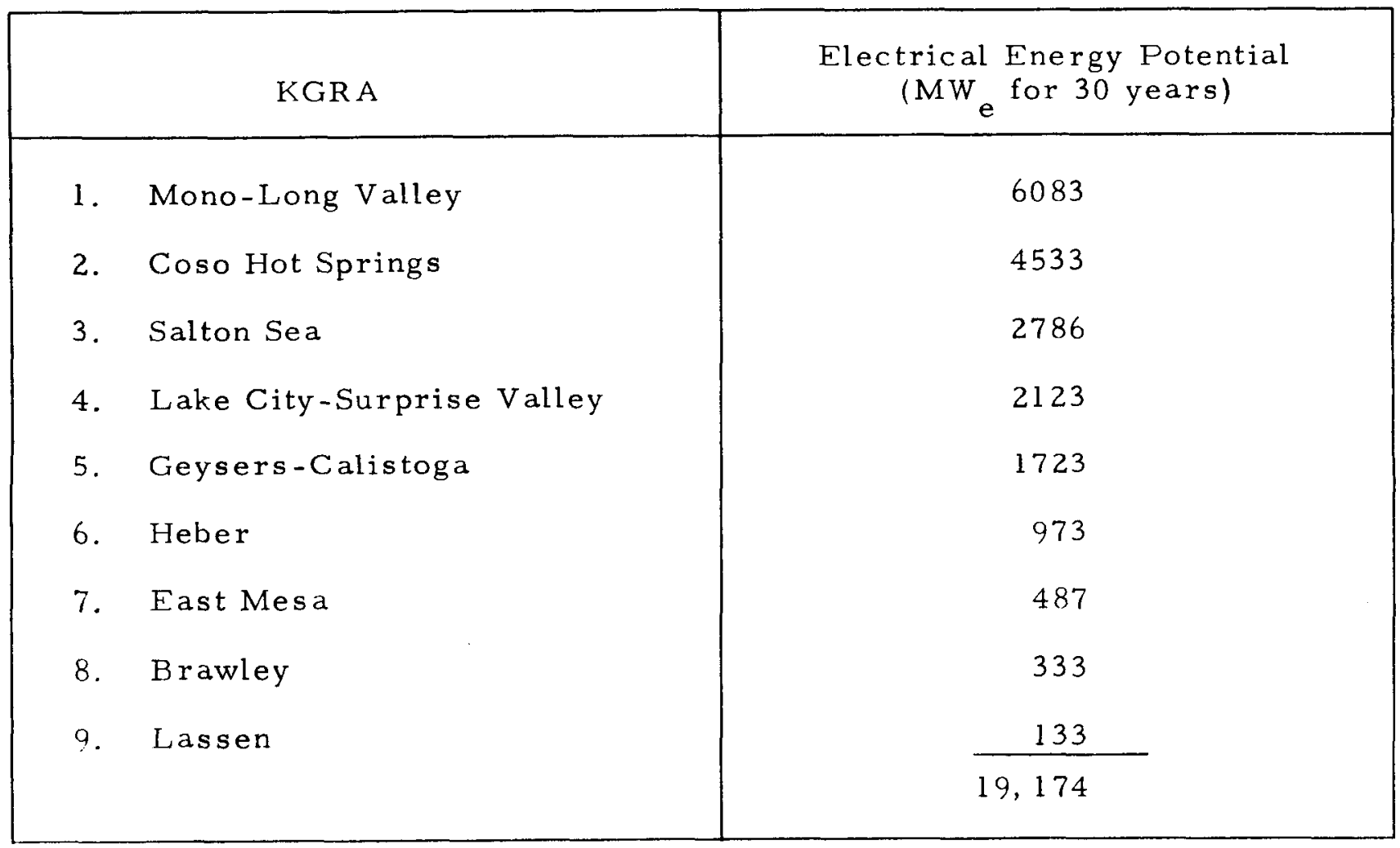

(2) The ongoing efforts of the CERCDC and ERDA, with the cooperation of industry and the USGS, are directed at better quantifications of the resource. There are considerable differences of expert opinion in the geothermal community on the potential of various resources in the state. Many feel the USGS estimates are conservative. It should be recognized that exploration for geothermal resources in its earliest stages and, as a result, resource knowledge is highly limited. Therefore it can be expected that further exploration may show a significant number of additional gcothermal fields in the state with electric energy potential besides those listed in Table 2-2 (or in Ref. 2-1). Further exploration also could considerably modify the estimates and ranking (both higher and lower) for the sites identified by the USGS. 
There are large uncertainties in the USGS assessment. With exception of The Geysers and some of the fields of the Imperial Valley, little of the deep drilling necessary to confirm the existence and extent of geothermal reservoirs has occurred. Most of the data on the wells that have been drilled is proprietary and could not be used to support the energy estimates. As a result, the USGS assessment of the hydrothermal systems was based in large part on extrapolations of surface and near surface measurements and geological manifestations. Further research and exploration data is required to verify the accuracy of these estimates. The estimates of the energy content of the hot-igneous and conduction-dominated systems are even more speculative.

A discussion of the different resource types, their locations in the state, and estimates of their energy content is presented in the following subsections.

\section{HYDROTHERMAL SYSTEMS}

These systems consist of high temperature steam or hot water stored in a volume of porous, permeable reservoir rock. Heat is transferred from deep in the earth's crust by the convective circulation of the steam or water through faults and fractures in the reservoir rock. This stean or water also provides the vehicle by which the stored heat of the reservoir rock can be extracted and brought to the surface (Fig. 2-3). Geothermal reservoirs containing only steam are referred to as vapor-dominated (The Geysers, for example), whereas hot water reservoirs such as those typical of the Imperial Valley are referred to as liquid-dominated. Areas of geothermal interest are usually associated with hot springs, show geologic evidence of recent volcanic activity, and exhibit a high level of conductive heat flow, frequent seismic activity, and occasionally steam geysers or fumaroles. Throughout the world, liquid-dominated sites are much more numerous than vapor-dominated sites. 
VAPOR DOMINATED

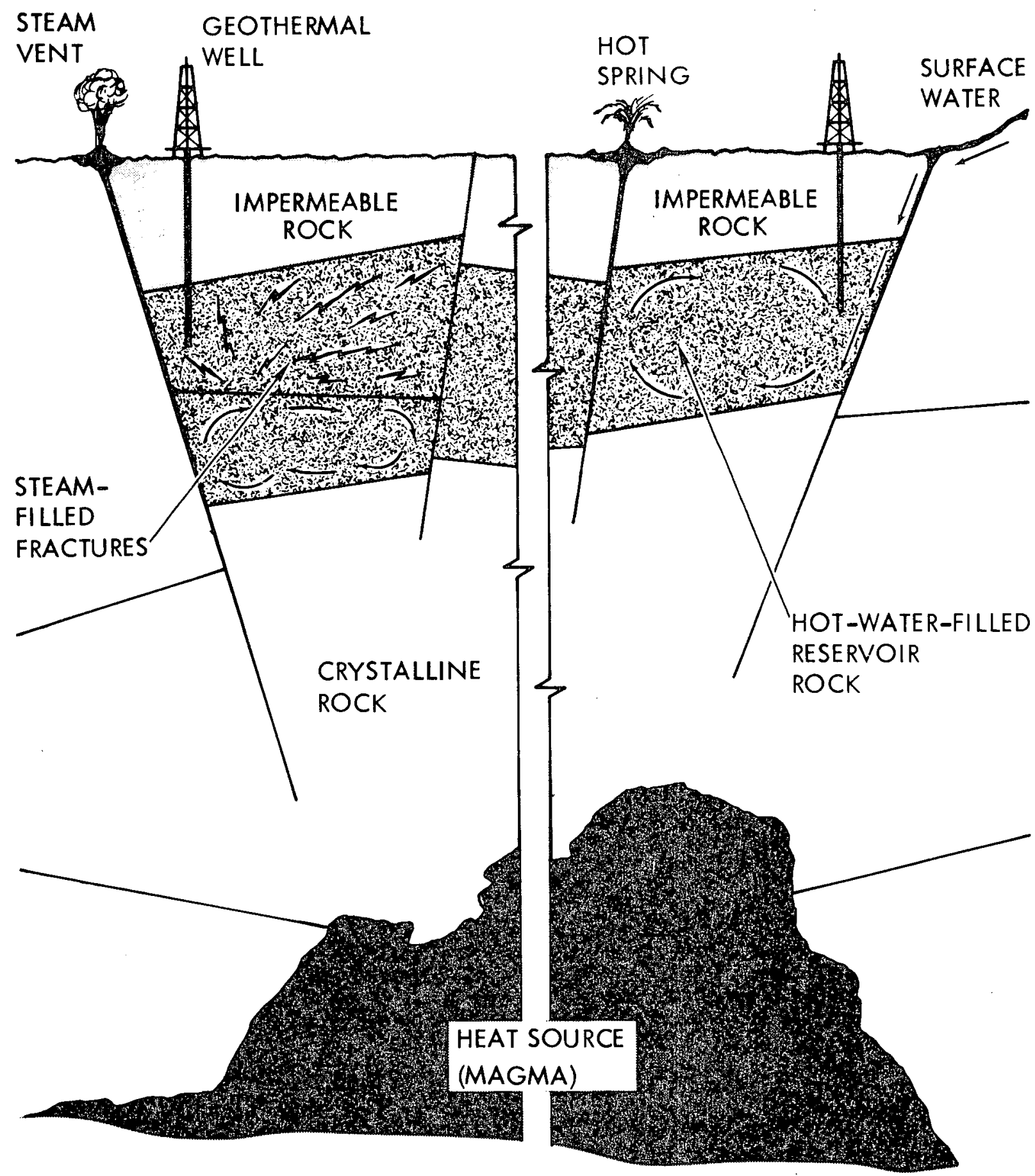

Fig. 2-3. Generalized hydrothermal reservoir 
ESTIMATED POTENTIAL OF IDENTIFIED HYDROTHERMAL RESOURCES

The USGS assessment identifies 62 hydrothermal systems in California: 16 with estimated temperatures above $150^{\circ} \mathrm{C}$ and 46 with estimated temperatures ranging from 90 to $150^{\circ} \mathrm{C}$. Those systems above $150^{\circ} \mathrm{C}$ may be suitable for electrical power production, whereas those of lower temperature may be important in nonelectrical applications. Figure 2-4 (Refs, 2-3 and 2-4) shows the location of these identified systems throughout the state. The USGS estimated the energy potential of each identified hot water system using the process diagrammed in Fig. 2-5. Reservoir temperature estimates were based primarily on geochemical analysis of surface waters from springs or shallow wells. Reservoir areas were estimated from all available data, which included surface manifestations and geology and, where available, geophysical data. The maximum reservoir depth was arbitrarily assumed to 3 kilometers (1.86 miles) the current limit of geothermal drilling. The top of the reservoir was generally assumed to have an average depth of $1,1.5$, or 2 kilometers 10.62 .0 .93$, or 1. 24 miles) depending on the assumed shape of the convection system and the inferred similarities to drilled areas. The volumetric specific heat of the rock was assumed to be $0.6 \mathrm{cal} / \mathrm{cm}^{3} \mathrm{C}$. These factors established the estimated heat content of the reservoirs (systems). The USGS then estimated the recoverable electrical energy potential of those identified systems with temperatures in excess of $150^{\circ} \mathrm{C}$. The estimation of the recovery factors generally involved three steps:

1) An estimation of what part of the hydrothermal system is porous and permeable rock (assumed 50\%).

2) An estimation of the fraction of the stored heat in the porous and permeable volume that $c$ an be recovered at the surface (assumed $50 \%$ ).

3) A calculation of the efficiency with which thermal energy at the wellhead can be converted to electrical energy in a power plant (varied as a function of temperature).

The estimated recovery factors for hot water systems ranged from $2 \%$ for temperatures of $150-200^{\circ} \mathrm{C}$ to $3 \%$ for temperatures of $250-300^{\circ} \mathrm{C}$. It was even 


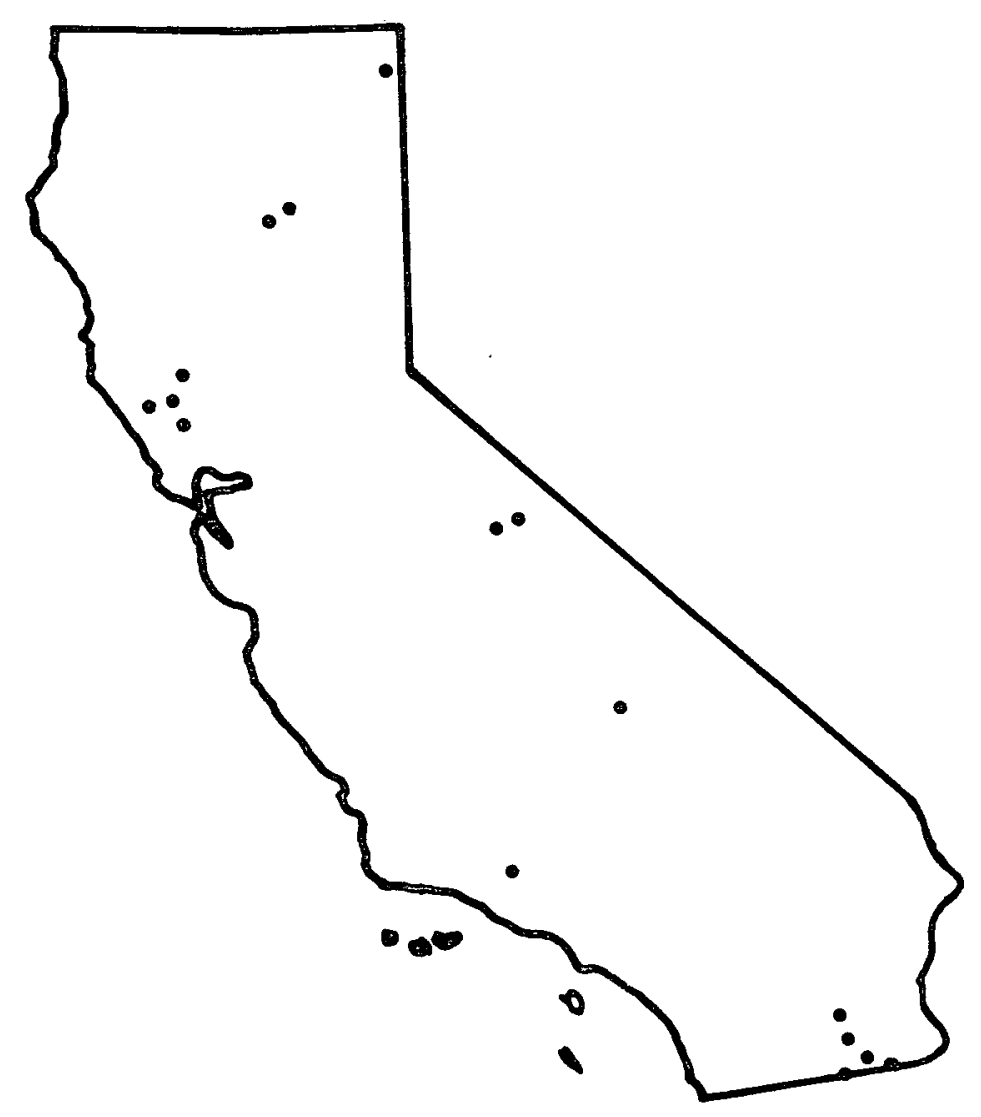

TEMPERATURES ABOVE $150^{\circ} \mathrm{C}$

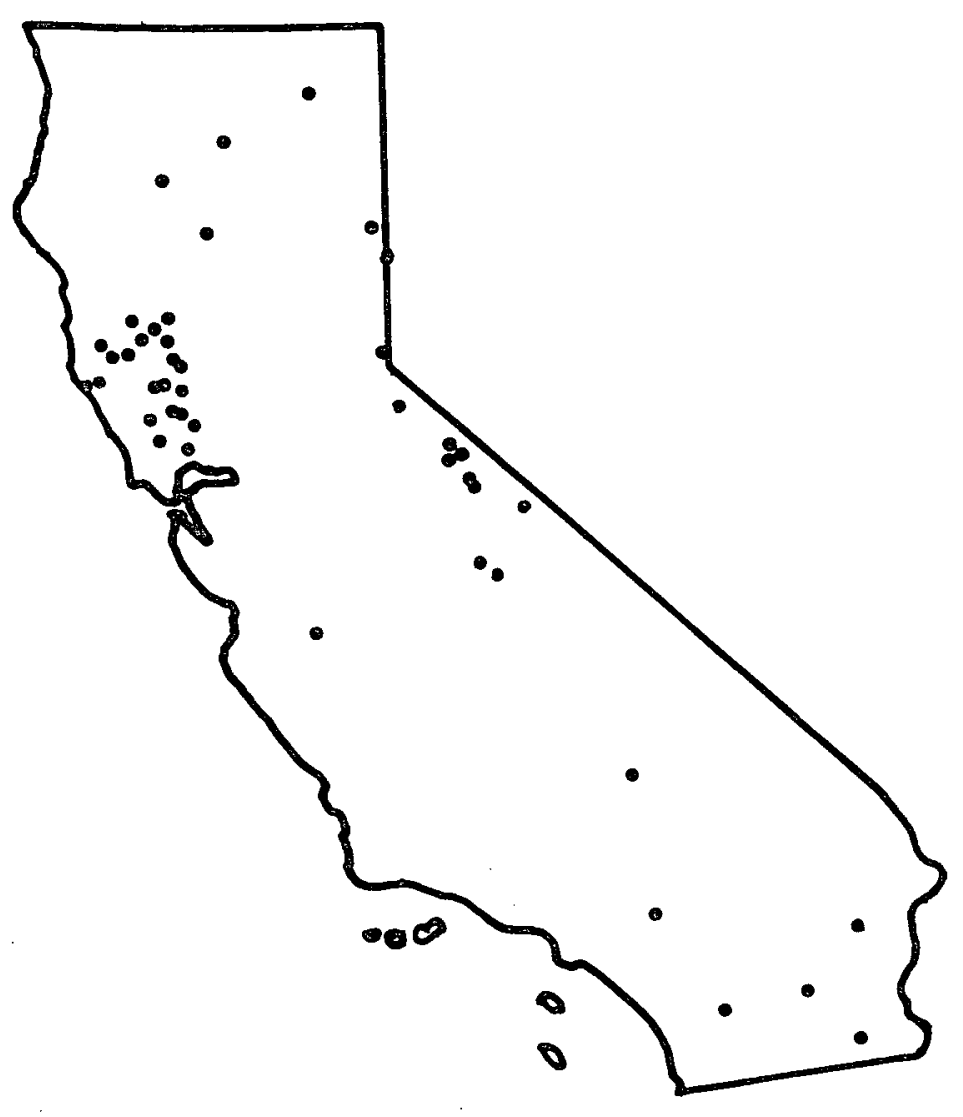

TEMPERATURES $90-150^{\circ} \mathrm{C}$ 


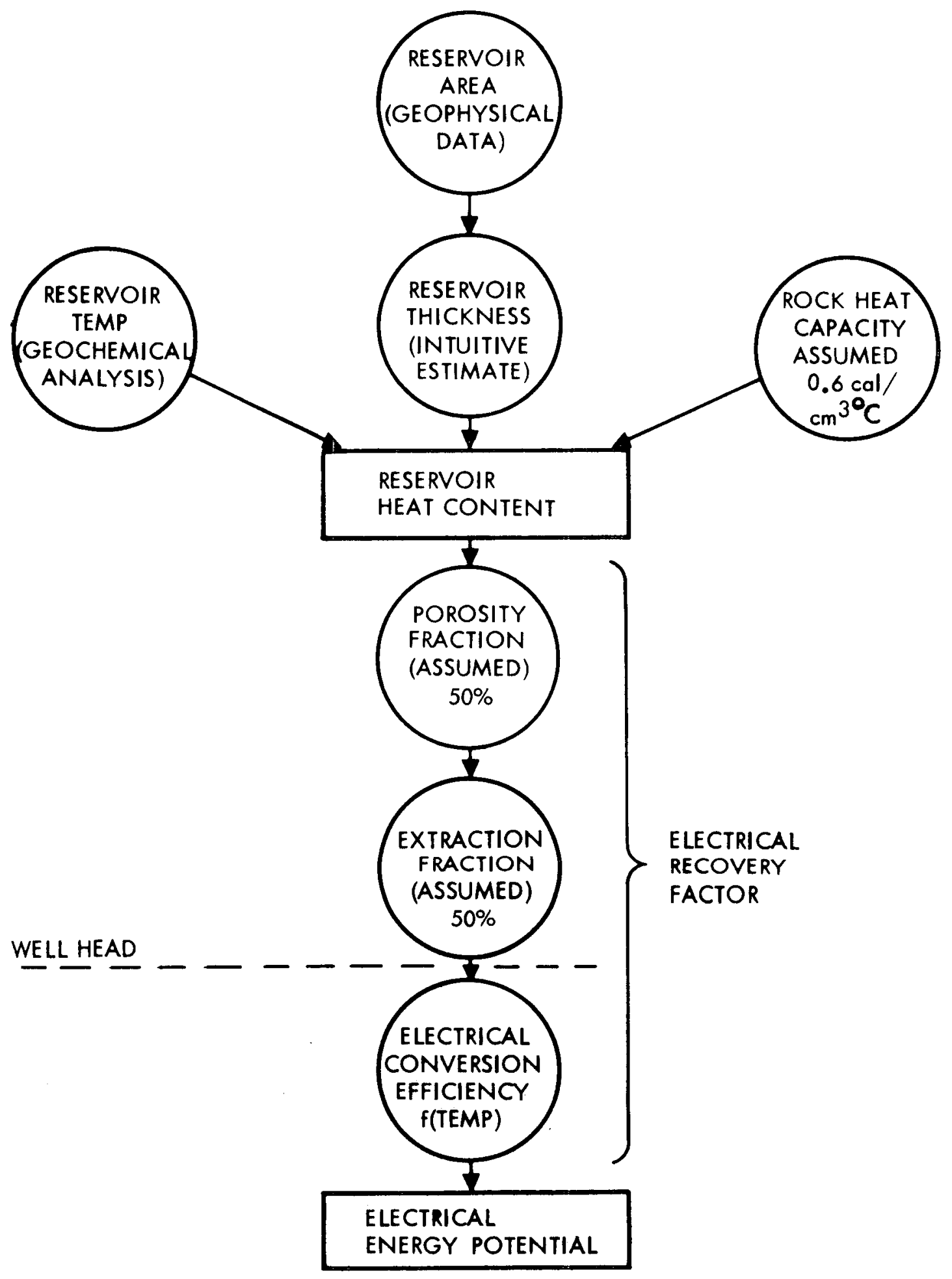

Fig. 2-5. USGS hydrothermal energy potential as sessment process 
less for vapor-dominated systems. The distribution of identified resource potential within the current KGRAs is shown in Table 2-3. Eighteen of the 23 KGRAs are associated with identified hydrothermal systems; nine above $150^{\circ} \mathrm{C}$ and nine in the intermediate temperature range. Five have no energy assessments by the USGS.

\section{REGIONAL HYDROTHERMAL RESOURCE KNOWLEDGE}

More is known about the resource in The Geysers region than those in the other regions of the state. The Geysers steam field is responsible for most of the geothermal production in California and is the only producing steam field in the United States. Knowledge of the reservoir production characteristics, temperature, and resource boundaries results from the drilling of over 150 wells (Ref. 2-5) in the area. However, the resource boundaries are still known only approximately and exploration efforts are extending many miles from the production wells. The ultimate capacity of this region depends on how successful the efforts are to discover extensions to the identified reservoirs.

The knowledge of the Imperial Valley Region's geothermal resources approaches that of The Geyser's Region. This region has been the subject of extensive geophysical surveys which have helped to define the identified resource areas. Deep drilling has now occurred at the majority of the resource sites in the region (Brawley, Dunes, East Mesa, Heber, and Salton Sea). The data on the wells at Brawley, Heber, and the Salton Sea is proprietary. However, two independent assessments of the energy potential of the region are in reasonable agreement with those of the USGS (Refs. 2-6 and 2-7).

The Eastern Sierra Region is unique in that, although it potentially contains the largest resources in the state, there has been very little exploratory drilling. The two major resources in the region are in the Mono-Long Valley and Coso Hot Springs areas. Estimates of the potential for Mono-Long Valley indicate a resource larger than the total Imperial Valley Region. These estimates are based on the results of an extensive USGS geophysical and geological survey of the Long Valley area. The outline of the collapsed structure of a volcano 
Table 2-3. Idertified potential of geothermal resource areas

\begin{tabular}{|c|c|c|c|c|}
\hline 1.ocation/KGRA & $\begin{array}{c}\text { Circular } 726 \\
\text { Designation }\end{array}$ & $\begin{array}{l}\text { Estimated } \\
\text { Reservoir } \\
\text { Temperature, }{ }^{\circ} \mathrm{C}\end{array}$ & $\begin{array}{c}\text { Total Reservoir } \\
\text { Heat Content, } \\
\text { quads }\end{array}$ & $\begin{array}{c}\text { Electric Energy } \\
\text { Potential } \\
\text { MWe for } \\
30 \text { years }\end{array}$ \\
\hline \multicolumn{5}{|c|}{ THE GEYSERS REGION } \\
\hline $\begin{array}{l}\text { Geysers-Calistoga } \\
\text { Knoxville } \\
\text { Little Horse Mtn. } \\
\text { Lovelady Ridge } \\
\text { Witter Springs }\end{array}$ & $\begin{array}{l}\text { The Cieysers } \\
\text { Calistoga } \\
\text { Sulphur Bank Mine } \\
\text { Skagg's Hot Spg. (a) } \\
\text { Wilbur Hot Spg. (a) } \\
\text { One Shot Mining } \\
\text { Crabtree Hot Spg. } \\
\text { Cook Springs } \\
\text { Saratoga Springs }\end{array}$ & $\begin{array}{l}240 \\
160 \\
185 \\
155 \\
135 \\
150 \\
150 \\
140 \\
140\end{array}$ & $\begin{array}{r}75 \\
3 \\
-2 \\
1 \\
10 \\
\sim 1 \\
-1 \\
\sim 1 \\
-1 \\
95\end{array}$ & $\begin{array}{r}1589 \\
70 \\
37 \\
27 \\
\text { (c) } \\
(\mathrm{c}) \\
\text { (c) } \\
(\mathrm{c}) \\
\text { (c) } \\
1722\end{array}$ \\
\hline \multicolumn{5}{|c|}{ IMPERIAL VALLEY REGION } \\
\hline $\begin{array}{l}\text { Brawley } \\
\text { Dunes } \\
\text { East Miesa } \\
\text { Ford Dry Lake } \\
\text { Glamis } \\
\text { Heber } \\
\text { Salton Sea }\end{array}$ & $\begin{array}{l}\text { Brawley } \\
\text { Dunes } \\
\text { East Mesa } \\
\text { Border } \\
\quad \text { (b) } \\
\text { Glamis (East) } \\
\text { Heber } \\
\text { Salton Sea } \\
\text { Pilger Estate H.S. }\end{array}$ & $\begin{array}{l}200 \\
135 \\
180 \\
160 \\
- \\
135 \\
190 \\
340 \\
145\end{array}$ & $\begin{array}{c}12 \\
\sim 2 \\
22 \\
\sim 1 \\
- \\
\sim 2 \\
44 \\
83 \\
-1 \\
167\end{array}$ & $\begin{array}{r}333 \\
(c) \\
487 \\
(c) \\
- \\
(c) \\
973 \\
2786 \\
(c) \\
4579\end{array}$ \\
\hline \multicolumn{5}{|c|}{ EASTERN SIERRA REGION } \\
\hline $\begin{array}{l}\text { Bodie } \\
\text { Coso Hot Springs } \\
\text { Mono Long Valley } \\
\text { Randsburg } \\
\text { Saline Valley }\end{array}$ & $\begin{array}{l}\text { (b) } \\
\text { Coso Hot Spg. } \\
\text { Long Valley } \\
\text { Near Black Pt. } \\
\text { Paoha Island } \\
\text { Red's Meadow } \\
\text { Randsburg } \\
\quad \text { (b) }\end{array}$ & $\begin{array}{l}- \\
220 \\
220 \\
125 \\
125 \\
165 \\
125 \\
-\end{array}$ & $\begin{array}{r}163 \\
218 \\
-1 \\
-1 \\
-1 \\
-2 \\
- \\
386\end{array}$ & $\begin{array}{r}- \\
4533 \\
6083 \\
(c) \\
(c) \\
(c) \\
- \\
10,616\end{array}$ \\
\hline \multicolumn{5}{|c|}{ NORTHEAST REGION } \\
\hline $\begin{array}{l}\text { Beckwourth Peak } \\
\text { Glase Mountain } \\
\text { Lake City-Surprise Valley } \\
\text { Lassen } \\
\text { Wendel-Anedee }\end{array}$ & $\begin{array}{l}\quad \text { (b) } \\
\quad \text { (b) } \\
\text { Surprise Valley } \\
\text { Morgan Springs } \\
\text { Wendel-Amedee }\end{array}$ & $\begin{array}{l}- \\
175 \\
210 \\
140\end{array}$ & $\begin{array}{r}- \\
- \\
95 \\
-5 \\
-5 \\
130\end{array}$ & $\begin{array}{r}- \\
- \\
2123 \\
133 \\
\text { (c) } \\
2256\end{array}$ \\
\hline \multicolumn{5}{|c|}{ CENTRAL COAST REGION } \\
\hline Sespe Hot Springs & Sespe Hot Spg. & 155 & $\sim 1$ & (c) \\
\hline $\begin{array}{l}\text { Notes: } \\
\text { (a) Outside of KGR } \\
\text { (b) No data availab } \\
\text { (c) Temperature to } \\
\end{array}$ & $\begin{array}{l}\text { oundaries. } \\
\text { ow for commercial }\end{array}$ & generation but & valuable for $n$ & ectric \\
\hline
\end{tabular}


(caldera) covering over $350 \mathrm{~km}^{2}$ (135 square miles) surrounds the area of the possible reservoir. Interpretation of geophysical surveys indicates that a reservoir of $225 \mathrm{~km}^{2}$ ( 87 square miles) underlies the caldera.

The Coso Hot Springs KGRA in the Eastern Sierra Region is estimated to have a resource potential roughly equal to the Imperial Valley Region. There has been no deep drilling activity in the resource area and estimates are based only on surface manifestations and geophysical surveys. However, geophysical exploration of this resource has not been as detailed nor covered as much area as that in Long Valley. Duffield has recently found an oval-shaped ring of faults covering $1500 \mathrm{~km}^{2}$ (580 square miles) and surrounding the area of hot springs (Ref. 2-8). This ring structure suggests a large underlying magma chamber. However, based on the limited area covered by geophysical surveys in the regior to date, the USGS estimates a reservoir covering $168 \mathrm{~km}^{2}$ ( 65 square miles) or approximately one-tenth the area indicated by the ring structure. Further surveys and deep drilling will provide a more precise picture of this resource.

Exploration date on the resources of the Northeast and Central Coast Regions is limited. Drilling has occurred primarily in the Lake City-Surprise Valley and Wendel-Amedee areas. Less data is available on the potential of the other KGRAs in these regions.

\section{ESTIMATION UNCER TAINTIES}

The process used to estimate the potential of the identified resources in California is subject to large uncertainties. The temperatures used for most resources were estimated using geochemical analysis of $\mathrm{SiO}_{2}$ and $\mathrm{Na}-\mathrm{K}-\mathrm{Ca}$ ratios of surface water samples. This analysis process gives the minimum value of the reservoir temperature, as was indicated by the USGS report. This tendency to underestimate temperature is supported by the results of a recent summary of exploration experience (Ref. 2-9), which presented a comparison of geothermometer data and actual reservoir data. Temperature is a particularly critical parameter in electric power generation. Water flashed from 
$300^{\circ} \mathrm{C}$ to a separator yields $33 \%$ steam; $200^{\circ} \mathrm{C}$ yields $11 \%$; and $150^{\circ} \mathrm{C}$ yields none (Ref. 2-10). Thus, the estimated electric energy potential of the identified systems could be low due to underestimation of reservoir temperatures. (This may be mitigated somewhat by the relatively low value, $150^{\circ} \mathrm{C}$, used for minimum reservoir temperature for electric energy production.) The estimates of reservoir area were also felt to contain large uncertainties. The calculation of recoverable energy made the assumption that $25 \%$ of the heat content of the reservoir could be extracted (i.e., brought to the wellhead). The actual value of this parameter can vary greatly from reservoir to reservoir and can even vary within a single reservoir.

Many of the identified systems are listed with small heat contents (less than 4 quads). These resources should not necessarily be considered insignificant. In many cases the small estimate is the result of very limited knowledge about the subsurface features of the resource. These estimates are based primarily on the area covered by surface manifestations, which may have little relationship to the actual size of the reservoir. Investigations need to be performed at these sites before better estimates of their potential can be made.

\section{UNDISCOVERED HYDROTHERMAL RESOURCE POTENTIAL}

USGS estimates that future discoveries will be possibly five times the volume and heat content of the high temperature systems already identified and three times that of the presently known intermediate temperature systems. Here discovery could result from:

1) New knowledge of the extent of an al ready identified system that increases its estimated volume appreciably.

2) The temperature of an identified system being higher than first estimated - enough possibly to raise it into the higher temperature category.

3) The discovery of a previously unknown system that had no obvious surface evidence of its existence. 
As further evidence of the possibility of future discoveries, it should be noted that many warm springs exist in California that have not been evaluated. In addition, little data is available on most of the 46 intermediate temperature systems identified (Ref. 2-11).

HOT-IGNEOUS SYSTEMS

The hot-igneous (volcanic) systems occur in regions where molten magma generated deep in the Earth's crust or mantle has risen upward through narrow pipes and fissures to form magma chambers in the shallow crust. Unlike basaltic magma, which is commonly erupted at the surface and its heat dispersed, silicia magma commonly comes to rest as large masses at depth of a few kilometers, thus conserving its heat. It is the thermal anomalies associated with silicia volcanic systems that are of economic interest. The hot-igneous category consists of systems still partly molten, with temperatures in excess of $650^{\circ} \mathrm{C}$, and hot dry rock systems where the magma is no longer molten (i.e., less than $650^{\circ} \mathrm{C}$ ) but still very hot. The USGS (Ref. 2-12) has identified $17 \mathrm{such}$ silicia volcanic systems in California (Fig. 2-6). The heat content of the 10 systems on which some data exists was estimated by USGS to be roughly 14,700 quads (Ref. 2-13). This is almost 20 times that estimated for identified hydrothermal systems. These estimates are very speculative as the data available on these systems is limited.

The heat in the molten parts of magmatic systems is not recoverable with current technology. The tops of the inferred magma bodies lie at estimated depths that are all greater than 3 kilometers $(1.86$ miles). Because of the depths and the high temperatures involved $\left(650\right.$ to $\left.1200^{\circ} \mathrm{C}\right)$, technology problems are formidable. (The feasibility of utilizing the energy contained in magma is presently being evaluated by Sandia Laboratories under a project started in 1974 with the support of ERDA.)

Much heat is also stored on the margins of the molten systems and in the now-solidified systems (i.e., temperatures less than $650^{\circ} \mathrm{C}$ ). These systems constitute favorable targets for recovering heat energy by using hydraulic fractures to produce circulation loops in a body of low-permeability rock. This 


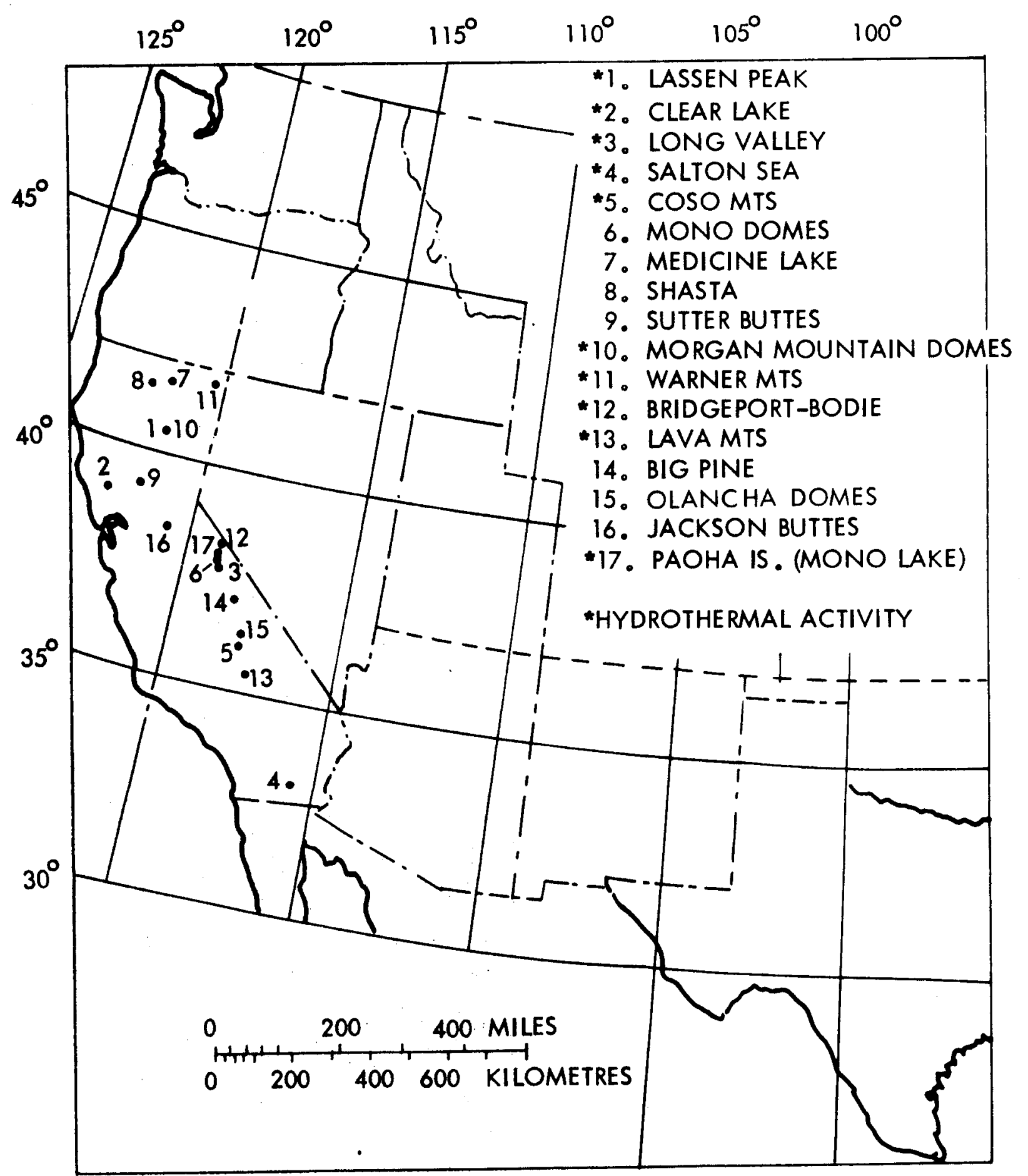

Fig. 2-6. California's identified volcanic systems 
is the purpose of the hot dry rock project under way at Los Alamos, which also is under ERDA sponsorship. Although the results to date on this project are encouraging, many problems still have to be solved before the hot dry rock concept is proven.

CONDUCTION-DOMINATED AND GEOPRESSURED SYSTEMS

Conduction-dominated heat flow regions underlie most of the United States. This category constitutes by far the largest part of the resource base. The volume of rock involved is large but the average temperatures are low. Most of the heat is transferred from deep within the Earth by thermal conduction through solid rock. Some heat is generated by normal radioactivity of rocks in the upper crust. The heat content in California is estimated to exceed 635, 000 quads (Ref. 2-14). The basin and range provinces typical of parts of California and the West have the highest temperature gradients. The East is characterized by "normal" gradients. Although this resource is large, generally the extraction of energy from these systems requires very deep wells, in the range of 5 to 10 kilometers $(15,000$ to 30,000 feet) in order to obtain temperatures of greater than $100^{\circ} \mathrm{C}$. Therefore, utilization of these resources is not now economical. Low grade hydrothermal resources, which have seen very little development, represent a much more attractive resource at the present time.

The geopressured geothermal resource represents a special category of this resource. Geopressured resources consist of zones of hot water, highly pressurized by the weight of the overlying geological formation. Large areas of this resource have been identified in the Gulf Coast staies. Energy is stored by this resource in the form of thermal energy, hydraulic energy of the high pressure fluid, and combustion energy of dissolved naturai gas. Studies of high fluid pressure regions of California by F. A. Berry (Ref. 2-15) indicate that an extensive zone of high pressure fluid 40-130 kilometers (25-80 miles) wide and 650-800 kilometers long (400-500 miles) long extends along the east side of the San Andreas fault. Temperatures associated with this region are, however, not of geothermal interest. A possible exception to this may occur in the southern San Joaquin Valley, where temperatures may exceed $100^{\circ} \mathrm{C}$. However, little data is available on the extent of this resource. 


\section{REFERENCES}

2-1. Assessment of Geothermal Resources of the United States - 1975 , Geological Survey Circular 726, U. S. Geological National Center, Reston, Virginia.

2-2. Ibid., Table 16, pg. 108.

2-3. Ibid., Figure 1, pg. 22.

2-4. Ibid., Figure 3, pg. 50 .

2-5. Records of the California Division of Oil and Gas.

2-6. Towse, D., An Estimate of the Geothermal Energy Resource in the Salton Trough, California, Lawrence Livermore Laboratory Report UCRL-51851, 1975.

2-7. Biehler, S., personal communications, 1976.

2-8. Duffield, W. A., "Late Cenozoic Ring Faulting and Volcanism in the Coso Range Areas of California, "Geology, Vol. 3, pg. 335, 1975.

2-9. McNitt, J. R., Summary of United Nations Geothermal Exploration

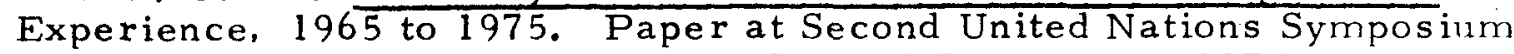
on the Development and Use of Geothermal Resources, 1975.

2-10. Ibid. $(2-1)$, pg. 7 .

2-11. Ibid. $(2-1)$, pg. 53 .

2-12. Ibid. $(2-1)$, Figure 5, pg, 77 .

2-13. Ibid. $(2-1)$, Table 7, pgs. 68-69.

2-14. Ibid. $(2-1)$, estimated from Table 13, pg. 92.

2-15. Berry, F. A. F., "High Fluid Potentials in California Coast Ranges and Their Significance," AAPG Bulletin, Vol. 7, pg. 217, 1973. 
PRESENT PLANS FOR UTILIZATION OF GEOTHERMAL ENERGY

UTILIZATION BY ELECTRIC UTILITIES - OVERVIEW

The largest currently identified market for geothermal energy is electric power production. By 1985, the annual electric energy consumption in the state is projected in a recent study (Ref. 3-1) to increase from 160 billion $\mathrm{kW}-\mathrm{hr}$ in 1975 to a minimum of 239 billion and a maximum of 289 billion $\mathrm{kW}-\mathrm{hr}$, or an average power demand increase of 10,000 to $16,000 \mathrm{MW}$. Generating capacity of this order of magnitude will have to be installed within this period. To establish the present picture for potential penetration of this market by geothermal energy, a survey of eight electric utilities known to be interested in geothermal energy was conducted. These utilities, who furnish over $80 \%$ of the power consumed in the state, were:

- Pacific Gas and Electric Co.

- Southern California Edison Co.

- San Diego Gas and Electric Co.

- Northern California Power Agency

- California Department of Water Resources

- Imperial Irrigation District

- Sacramento Municipal Utilities District

- City of Burbank

The survey sought to establish three things:

- The present plans of each utility for adding new generating capacity over the next 20 years, including the type of capacity planned.

- Of those planned capacity additions for which geothermal energy is not presently being considered, which additions might be switched to geothermal energy if it were available. 
- What preconditions each utility would insist be met before considering such a switch, and by when such preconditions would have to be met.

The responses indicated a growing commitment to geothermal energy among the state's utilities. Of the eight utilities contacted, four have included geothermal generating capacity in their present 10 -year forecasts, and the others are actively considering it. If the existing plans are realized, geothermal generating capacity will rise from the present $502 \mathrm{MW}$ to nearly $2300 \mathrm{MW}$ by 1985 , almost entirely at The Geysers (see Fig. 3-1). ${ }^{1}$ Early demonstration of the practicability of using the high salinity and/or moderate temperature resources of the Imperial Valley could increase this total by as much as $400 \mathrm{MW}$. Although the potential fivefold increase over present utilization is impressive, it should be noted that this still represents utilization of only $14 \%$ of the identified geothermal resources in the state. It also represents a maximum of only $25 \%$ of the potential new market. Discovery of new geothermal deposits could lead to further increases.

The utilities, although optimistic about the future of geothermal energy, also voiced some strong concerns, chief among which was the question of obtaining environmental approval. Many of the respondents predicated their commitment to geothermal development on a streamlining of the present approval process and a clarification of environmental standards. Under the present system, they can envision 2 to 4 year construction delays while awaiting approval; the impact of such delays on availability of generating capacity could be a sufficient deterrent to prevent them from committing to geothermal enterprises. (2)

The responses received are presented for each utility contacted. A general prefatory remark applies to all responders: Each response is predicated

1. While the $2300 \mathrm{MW}$ exceeds the current USGS estimate for The GeysersCalistoga field (re: Table 2-2) it is within the potential of The Geysers Region which has been estimated by industry to be as much as $6000 \mathrm{MW}$.

(2) The Warren-Alquist Act (Pub. Res. Code 25540) requires the CERCDC to complete its certification process in 18 months; 9 months to process a notice of of intent and 9 months to process an application for certification. However, no application has yet tested the CERCDC procedures at this time. 
on the present perceptions of the utility, based on existing conditions in California and reasonable projections of future demand. New factors, such as the possible nonavailability of nuclear power, were not considered. If for any reason such factors should become real, the projections presented here would be considerably altered.

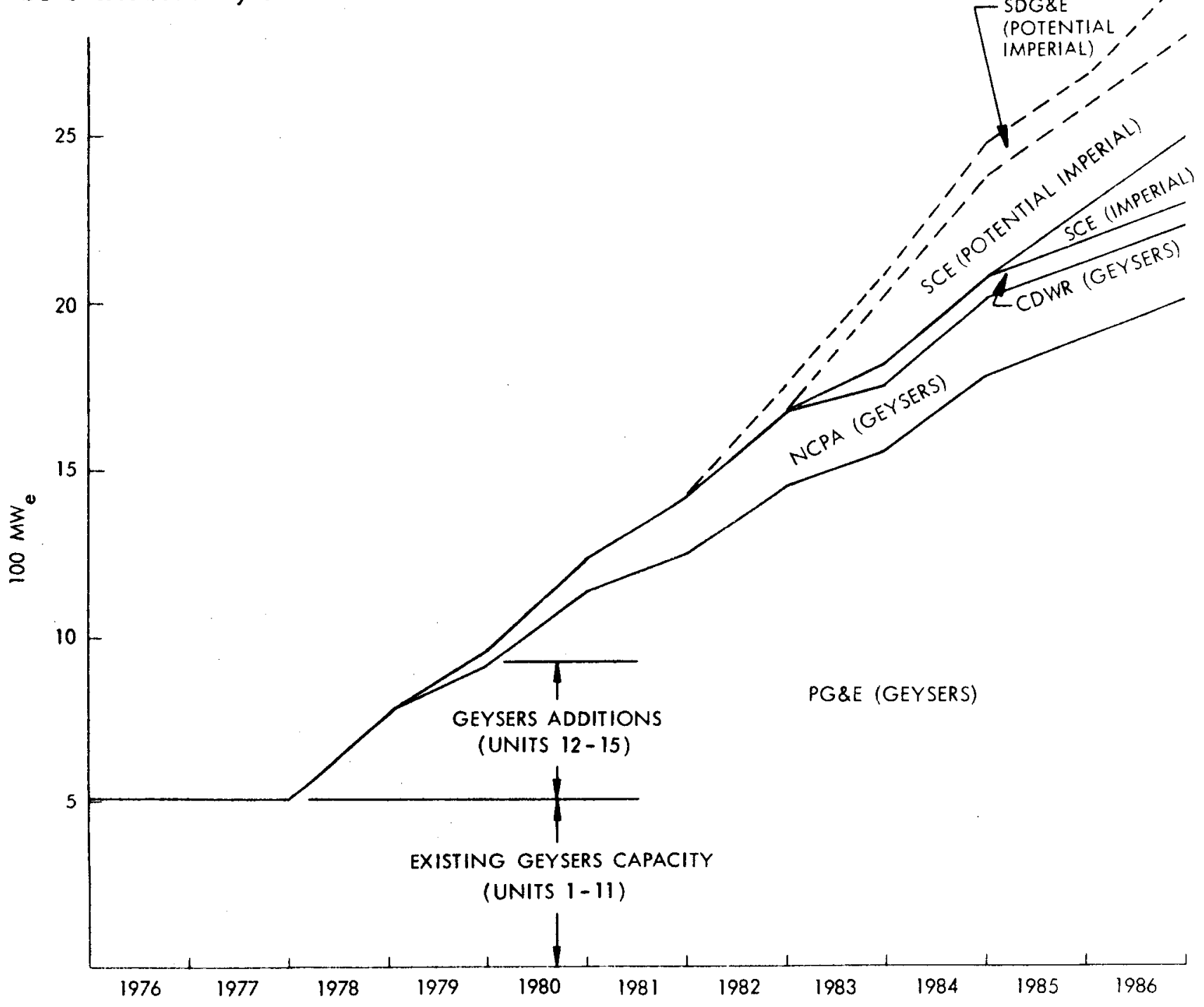

Fig. 3-1. Planned geothermal generating capacity in California

\section{*NOTE:}

1. The existing generating capacity at The Geysers is $502 \mathrm{MW}$ which will be increased to $908 \mathrm{MW}$ with the completion of the planned units $12-15$. That capacity projected in excess of the $908 \mathrm{MW}$ should be viewed as an indication of utility interest but not necessarily a firm commitment. 
PACIFIC GAS AND ELECTRIC COMPANY

Present Plans for Additional Generating Capacity

The present 10-year plan of the Pacific Gas and Electric Company (PG\&E) for installation of new capacity is shown below (in MW):

\begin{tabular}{|c|c|c|c|c|c|c|c|c|c|c|c|}
\hline Type/Year & 1976 & 77 & 78 & 79 & 80 & 81 & 82 & 83 & 84 & 85 & Totals \\
\hline Coal & & & & & & & & 800 & & & 800 \\
\hline Nuclear & 1060 & 1060 & & & & & & & & 1472 & 3592 \\
\hline Oil/Gas & 225 & 171 & 17 & & 707 & 120 & 75 & 375 & 675 & & 2365 \\
\hline Hydroelectric & & & & & & & & 130 & 150 & & 280 \\
\hline Pump Storage & & & & & & 1125 & & & & & 1125 \\
\hline $\begin{array}{l}\text { Geothermal } \\
\text { (The Geysers) }\end{array}$ & & & 271 & 135 & 220 & 110 & 220 & 110 & 220 & 110 & 1396 \\
\hline Totals & 1285 & 1231 & 288 & 135 & 927 & 1355 & 295 & 1415 & 1045 & 1582 & 9558 \\
\hline
\end{tabular}

PG\& $\mathrm{E}$ plans to install $1506 \mathrm{MW}$ of additional geothermal capacity at The Geysers, $1396 \mathrm{MW}$ of it by 1985, to bring their total capacity there to $2008 \mathrm{MW}$ This corresponds to their present best estimate of the capacity of The Geysers reservoir. The present schedule of development is dictated in the early years primarily by regulatory and permitting requirements and to some extent by design lead time; in later years it is predicated on PG\& E's estimates of the pace at which steam suppliers will prove out new areas of the reservoir. The present schedule also represents an accelerated development pace compared to previous $\mathrm{PG} \& \mathrm{E}$ plans. Beyond $1985 \mathrm{PG} \& \mathrm{E}$ is planning primarily on nuclear energy to provide its base load requirements. However, if more geothermal power should prove feasible at The Geysers or elsewhere, PG\&E feels they 
could easily accommodate it in the resource program after 1985 by deferring equivalent nuclear capacity.

\section{Areas Where Changes Could Be Considered}

PG\& E would be quite willing to accelerate their present timetable for development at The Geysers even further, if there were reasonable assurance that regulatory approvals could be obtained with greater ease than heretofore, and if suppliers can accelerate their drilling activities. By so doing PG\&E could alleviate its dependence on oil-and gas-fired plants somewhat in the mid$1980 \mathrm{~s}$. At present, oil-fired plants provide nearly $50 \%$ of their area's installed generation capacity. Their projections show oil and gas consumption continuing to increase to a peak in the 1984-85 time period, with a gradual decrease thereafter as nuclear capacity escalates. Without the planned development of geothermal energy units at The Geysers $P G \& E^{\prime} s$ oil requirements would be even greater.

PG\& E's position relative to the utilization of other geothermal resources was positive but cautious; they would be willing to commit to the use of any resource once they were convinced that its overall economics and reliability had been established and if the resource were in their service area. They foresee no conflict in this with their nuclear program. For resources located outside their service area, their first inclination would be to urge its utilization by the local utility serving the area in which the resource was found. Realistically, they felt that capacity from new geothermal resources would not be available prior to 1988-90. This estimate is based on their own knowledge and experience with geothermal development.

Preconditions for Commitment to Additional Geothermal Energy

For The Geysers, PG\& $\mathrm{E}$ is committed to full development and will plan for capacity as continued exploration and assessment indicate that additional units are feasible. Based on past experience, 5 to 6 years lead time is required to bring new geothermal capacity on-line once PG\&E has committed to it. 
For other potential resources, $P G \& E$ would have to be convinced that (1) the regulatory environment would allow confidence in the development schedule; (2) the overall economics of the project, including transmission of the power. had been reasonably well established; (3) the capability of the steam reservoir to support the proposed power plant for at least 25 to 30 years had been reasonably well established; and (4) the technology to be used had been demonstrated to be technically and commercially viable, before they would make a firm commitment to its utilization. However, they would not require that these preconditions be met prior to initiation of early planning.

\section{SOUTHERN CALIFORNIA EDISON COMPANY}

\section{Present Plans for Additional Generating Capacity}

The present plan of the Southern California Edison Company (SCE) for additional generating capacity is shown below (in $\mathrm{MW}$ ):

\begin{tabular}{|l|c|c|c|c|c|c|c|c|c|c|c|c|}
\hline Type/Year & 1976 & 77 & 78 & 79 & 80 & 81 & 82 & 83 & 84 & 85 & $86-90$ & Totals \\
\hline Coal & 123 & -50 & & & -21 & 228 & 291 & 582 & 190 & -235 & & 1108 \\
Nuclear & & & & & 176 & 704 & 366 & 704 & & & 3952 & 5902 \\
Oil and Gas & 572 & & 472 & 180 & 720 & 266 & & 52 & 52 & 1064 & 1329 & 4707 \\
Hydroelectric & & & & & 29 & & & & & -309 & -963 & -1243 \\
Geothermal & & & & & & & & & & 100 & 100 & 200 \\
\hline
\end{tabular}

As indicated, geothermal energy does not figure in this plan until 1985. Between 1986 and 1995 the plan calls for exploitation of a number of new technologies, including the installation of $650 \mathrm{MW}$ of geothermal capacity. This 
plan is predicated on a successful development/test program of direct flash technology for the hypersaline brines of the Salton Sea area.

\section{Areas Where Changes Could Be Considered}

SCE is very interested in reducing their oil - and gas-fired capacity. They indicated a willingness to reconsider fossil fuel plants scheduled for the $1980 \mathrm{~s}$. They felt geothermal energy was a viable alternative to fossil fuel for the mid1980 s.

SCE also expressed a great interest in the Long Valley area, where they may be partnered with Magma Energy Corporation. Although they are not presently planning new generating capacity there, they are concerned that the projected peak loads in the area will exceed the capability of the existing trans mission line, which is used to supplement local power generating capacity during peak load periods. They feel the transfer of the space-heating portion of the projected load to geothermal energy would obviate their presently foreseen need to upgrade the transmission line. Consequently, SCE plans to propose to ERDA a study of the feasibility of utilizing geothermal fluids to provide the spaceheating requirements of Mammoth Lakes Village. The study would also consider a total energy system, including a power plant whose warm effluent would be used for space-heating purposes.

\section{Preconditions for Commitment to Geothermal Energy}

SCE indicated that they would be willing to proceed immediately with commercial development of geothermal power given a resource which could be economically exploited with commercially available technology (i. e., flashedsteam technology), and given a regulatory environment sufficiently well defined to allow confidence in scheduling.

SCE further indicated that, although it would be preferable to have a risksharing partner, it would be willing to proceed on its own with a demonstration plant for establishing the economic feasibility of new utilization technology, 
given an appropriate resource. Such a plant could be operational by 1979-80 if started now. If this were done, SCE could envision 100-300 MW of geothermal capacity on-line in their system by the early 1980 s.

\section{SAN DIEGO GAS AND ELECTRIC COMPANY}

\section{Present Plans for Additional Generating Capacity}

The present plan of the San Diego Gas and Electric Company (SDG\&E) for adding capacity to their system is shown below (in $M W$ ):

\begin{tabular}{|c|c|c|c|c|c|c|c|c|c|c|c|c|}
\hline Type/Year & 1976 & 77 & 78 & 79 & 80 & 81 & 82 & 83 & 84 & 85 & $86-90$ & Totals \\
\hline Coal & & & & & & & 181 & 182 & 362 & & & 725 \\
\hline Nuclear & & & & & 44 & 176 & 44 & 176 & & 475 & 1475 & 2390 \\
\hline Oil and Gas & 32 & & 292 & 128 & & & & & & & & 452 \\
\hline Totals & 32 & & 292 & 128 & 44 & 176 & 225 & 358 & 362 & 475 & 1475 & 3567 \\
\hline
\end{tabular}

The plan presently provides for no geothermal generating capacity. SDG\&E indicated this plan will be revised about a year from now; the next revision will contain geothermal capacity if the planned SDG\&E experiment at Niland is successful. This experimental facility will become operational in March 1976. Approximately 18 months of operation would be needed to permit a decision for SDG\&E to proceed with a $50 \mathrm{MW}$ commercial plant. They felt such a plant could be on-line by 1982. A "completely arbitrary" schedule for additional geothermal capacity might be another $50 \mathrm{MW}$ plant in 1984, and then $100 \mathrm{MW}$ plants every 2 years until the full potential of the reservoir was reached. 
Areas Where Changes Could Be Considered

SDG\& E foresaw no difficulty in absorbing as much geothermal capacity as could be made available, with no impact on their present planned additions. They felt that perhaps the greatest economic justification for the use of geothermal energy could be in the backing down of existing oil-fired plants rather than the replacement of new capacity. They also felt it would be a good hedge against possible future slips in their coal and nuclear plants.

Preconditions for Commitment to Geothermal Energy

The only preconditions SDG\&E set on a commitment to geothermal energy development were a successful operation of the planned Niland experiment, and a high confidence in the reservoir capacity. They also indicated that, at least at present, their only interest is in the Imperial Valley; this is because of the transmission requirements. They are presently planning a high capacity transmission line from the proposed Sun Desert nuclear plant, to be installed by about 1981-82, which could be readily accessed from any site in the Imperial Valley. This line would be capable of handling any realistically anticipated geothermal capacity. For any other prospective geothermal area they foresee potential difficulties in transmitting the power to their network.

\section{CALIFORNIA DEPARTMENT OF WATER RESOURCES}

\section{Present Plans for Additional Generating Capacity}

The proposed generating capacity additions of the California Department of Water Resources (CDWR) are shown below (in $M W$ ):

\begin{tabular}{|c|c|c|c|c|c|c|c|c|c|c|c|c|}
\hline Type/Year & 1976 & 77 & 78 & 79 & 80 & 81 & 82 & 83 & 84 & 85 & $86-95$ & Totals \\
\hline $\begin{array}{l}\text { Hydroelectric } \\
\text { Geothermal }\end{array}$ & & & & & 77.5 & 92.5 & & & & & & 170 \\
\hline Totals & & & & & 77.5 & 92.5 & & 50 & & & & 220 \\
\hline
\end{tabular}


These capacity additions represent only a small portion of CDWR's projected future energy needs. The Department is considering participation in both the San Joaquin and Sun Desert nuclear projects, both due on-line in 1985 , and the Kaiparowits coal-fired plant.

\section{Areas Where Changes Could Be Considered}

CDWR is anticipating a shortfall over present capacity of 3 billion $\mathrm{kW}$ $\mathrm{hr} / \mathrm{yr}$ by 1983, rising to 6 billion $\mathrm{kW}-\mathrm{hr} / \mathrm{yr}$ by 1995. In this situation, the Department is considering all possible alternative energy sources, and is very interested in geothermal energy. The Department indicated it would take large amounts of geothermal power if it can be developed on an economical and timely basis.

\section{Preconditions for Commitment to Geothermal Energy}

The Department's plan presently includes a $50 \mathrm{MW}$ plant at The Geysers in 1983. The Department is willing now to commit to this plant provided it can obtain environmental approval; the only preconditions on this or any added capacity at The Geysers would be finding a steam supplier willing to sign a supplyor-pay contract for the geothermal steam, and obtaining suitable transmission arrangements.

The Department is also interested in the Imperial Valley, and is tentatively planning to build a pilot plant on land held by General Ener-Tech Corp. at the southern tip of the Salton Sea. General Ener-Tech's primary interest is the development of a bladeless turbine as an approach to overcome the difficulties of utilizing the very saline geothermal brines of the Salton Sea geothermal reservoir. CDWR indicated that proceeding with the pilot plant is currently dependent on preparing an Environmental Impact Report, and on the manufacturer's obtaining financing for development of the project.

CDWR further indicated they were willing to consider other projects, but have not had firm offers from other potential steam suppliers in the Imperial Valley. 
NORTHERN CALIFORNIA POWER AGENCY

\section{Present Plans for Additional Generating Capacity}

The present plan of the Northern California Power Agency (NCPA) for adding capacity to their system is shown below (in $\mathrm{MW}$ ):

\begin{tabular}{|l|l|l|l|l|l|l|l|l|l|l|l|}
\hline Type/Year & 1976 & 77 & 78 & 79 & 80 & 81 & 82 & 83 & 84 & 85 & Total \\
\hline Geothermal & & & & 55 & 55 & 55 & 55 & & & & 220 \\
\hline
\end{tabular}

NCPA is comprised of the power agencies of the cities of Redding, Roseville, Biggs, Gridley, Ukiah, Healdsburg, Alameda, Lodi, Santa Clara, Lompoc, Palo Alto, and the Plumas-Sierra Rural Electric Cooperative. They presently are distributors of power only, and have no generating capacity of their own. This situation should change in the near future. They are currently planning installation of $220 \mathrm{MW}$ of geothermal capacity at The Geysers, to be installed between 1979 and 1982. They are also negotiating for a $2 \%$ interest in the San Joaquin nuclear facility, although this does not appear in their present plan.

\section{Areas Where Changes Could Be Considered}

NCPA indicated great interest in additional geothermal capacity. They would be willing to reconsider participation in the San Joaquin nuclear project if equivalent geothermal resources could be made available; they would also seriously study geothermal energy for any proposed generating capacity additions in the future. Their interest is not restricted to The Geysers; they would be interested in geothermal fields anywhere in the state. 
Preconditions for Commitment to Geothermal Energy

As a small utility, NCPA is not in a position to as sume any risk in generating plants. It would require a demonstration of the economic performance of any new utilization technology (such as would be required for any geothermal field outside The Geysers). As with all utilities, it would also require a supply-or-pay contract with the field developer. In addition, for any fields remote from their service area, they would require firm wheeling contracts to assure adequate transmission of the power into northern California.

\section{IMPERIAL IRRIGATION DISTRICT}

\section{Present Plans for Additional Generating Capacity}

The present plan of the Imperial Irrigation District (IID) for adding capacity to their system is shown below (in MW):

\begin{tabular}{|c|c|c|c|c|c|c|c|c|c|c|c|}
\hline Type/Year & 1976 & 77 & 78 & 79 & 80 & 81 & 82 & 83 & 84 & 85 & Totals \\
\hline $\begin{array}{l}\text { Oil and Gas } \\
\text { Hydroelectric }\end{array}$ & 23 & & & & & & & & & & 23 \\
\hline Totals & 23 & & & 5 & & & & & & & 28 \\
\hline
\end{tabular}

Additional capacity will be installed to meet increased demands, but IID at this time has no definite plans defining size, type, or location.

\section{Areas Where Changes Could Be Considered}

The two projects listed above are fully committed. For all future capacity additions, IID is looking to geothermal energy. The district is heavily involved with several agencies in the development of geothermal energy, and 
although electric power production is still several years away, the district feels that geothermal energy can supply its future requirements. If geothermal energy is not available, the district foresees the need to add 100-150 MW of fossil-fueled generating capacity.

Preconditions to Commitment to Geothermal Energy

Before IID could commit to geothermal generating plants, they would require demonstration of 2 or more years of actual electric power production with minimal problems. Furthermore, firm guarantees for energy on demand, perhaps in the form of performance bonds, might be required.

\section{SACRAMENTO MUNICIPAL UTILITIES DISTRICT}

Present Plans for Additional Generating Capacity

The Sacramento Municipal Utilities District (SMUD) is in the process of formulating its long-range capacity addition plans. Detailed information on their plans is not available at present. Its baseline plan is nuclear-oriented; however, it is considering alternatives in the event that additional nuclear generation capacity is for any reason proscribed. One of the alternatives being seriously considered is geothermal energy. To this end, SMUD has had preliminary discussions with a potential hot-water supplier in the Northeast Region. A decision on whether to pursue this route further will be made about mid-1976.

\section{Preconditions for Commitment to Geothermal Energy}

SMUD indicated its first precondition to commitment to geothermal energy would be the lack of a viable nuclear alternative. SMUD presently operates one nuclear plant, and is planning a second nuclear unit at the same site. It is concern that this second unit will not be permitted because of nuclear waste disposal problems that has led SMUD to consider alternatives, including geothermal energy. SMUD hopes to reach a position on this second nuclear unit by mid-1976. If the decision is negative, then SMUD might proceed with a geothermal development. 
If SMUD does make a preliminary commitment to adopt a geothermal alternative, additional preconditions would have to be met before SMUD would finally commit to plant construction. These include a demonstration of the technology necessary for economic utilization of hot-water resources, and sufficient resource data to give SMUD confidence in both the longevity of the reservoir and the applicability of the demonstrated technology to the specific resource being considered. SMUD would thus foresee three activities proceeding in parallel:

1. Filing and processing all the necessary applications for construction of a geothermal plant at the proposed site (SMUD).

2. Detailed assessment of the prospective reservoir, including flow testing and drilling of step-out wells (jointly funded by SMUD and the potential supplier).

3. Construction and operation of a demonstration plant at a reservoir whose characteristics are sufficiently similar to the prospective reservoir to give SMUD confidence in the direct applicability of the technology demonstrated (this demonstration to be funded by EPRI, ERDA, or others).

Final commitment to construct a geothermal plant would not be made until SMUD was satisfied that all preconditions had been met.

\section{CITY OF BURBANK}

\section{Present Plans for Additional Generating Capacity}

Burbank's firmly planned capacity additions consist of $75 \mathrm{MW}$ of coal fired power from the Intermountain Power Project, in Utah, to come on line incrementally between 1982 and 1985. They are also tentatively planning $50 \mathrm{MW}$ of geothermal power, provided they find a resource.

Burbank presently holds leases on 6000 acres of prospective geothermal land at East Mesa in the Imperial Valley and in Long Valley, and has applications 
in process for 40,000 additional acres. Exploratory drilling at the East Mesa site during the fall of 1975 failed to produce water sufficiently hot for use in electric power generation, and attention shifted to Long Valley. Burbank will commence exploratory drilling there in April 1976. Should this drilling be successful, Burbank intends to proceed with installation of a $50 \mathrm{MW}$ plant. Over the next 25 years Burbank envisions the installation of 250 to $300 \mathrm{MW}$ of geothermal capacity.

\section{Areas Where Changes Could Be Considered}

Burbank is fully committed to the Intermountain Power Project, and does not foresee that commitment being influenced by the availability of geothermal energy. This is their only firmly planned capacity addition at present, although Burbank has studied a number of other projects and only recently declined participation in the Sun Desert nuclear plant. For any additional capacity beyond that provided by the Intermountain Power Project, geothermal energy is considered a prime candidate. They would also consider the installation of new geothermal capacity, given a proven resource of adequate characteristics, to replace existing capacity.

\section{Preconditions for Commitment to Geothermal Energy}

The only preconditions that Burbank places on proceeding with a geothermal plant is that (1) they find a resource on their lease holdings that is economically exploitable with present technology (even if the power conversion technology has not been fully demonstrated) and (2) they obtain the leases for which they have applied on the land adjacent to their holdings. The latter precondition they feel is necessary to provide adequate land to assure the longevity of any reservoir they may find. 
NONELECTRIC UTILIZATION OF GEOTHERMAL ENERGY

\section{APPLICATION POTENTIAL}

The electric power industry is the largest consumer of energy in the United States and is growing faster than the nonelectric industry. Most of the current geothermal development activities in the state are oriented to electric power generation. It has been estimated, however, that close to $60 \%$ of all energy required in the United States for other than transportation purposes can be provided by nonelectric utilization of thermal energy in the temperature range of 75 to $200^{\circ} \mathrm{C}$ (Ref. 3-2). This is shown graphically in Fig. 3-2. (Currently, for power generation to be economical, based on flashed-steam technology, a resource having a temperature in excess of $200^{\circ} \mathrm{C}$ is required.) This large potential for the use of moderate-to-low-temperature thermal energy represents a possible second important market for the utilization of geothermal energy.

Figure 3-3 shows the required temperature of geothermal fluids for various applications (Ref, 3-3). The industries which offer the largest potential for the usage of geothermal energy are:

- Residential space and water heating.

- Commercial space and water heating.

- Food products industry.

- Commercial space cooling.

- Paper and allied products industry.

- Chemical and petroleum industries.

The energy used in residential and commercial space and water heating in the three West Coast states is equivalent to that required for a $20,000 \mathrm{MW}_{\mathrm{e}}$ electric power plant. 


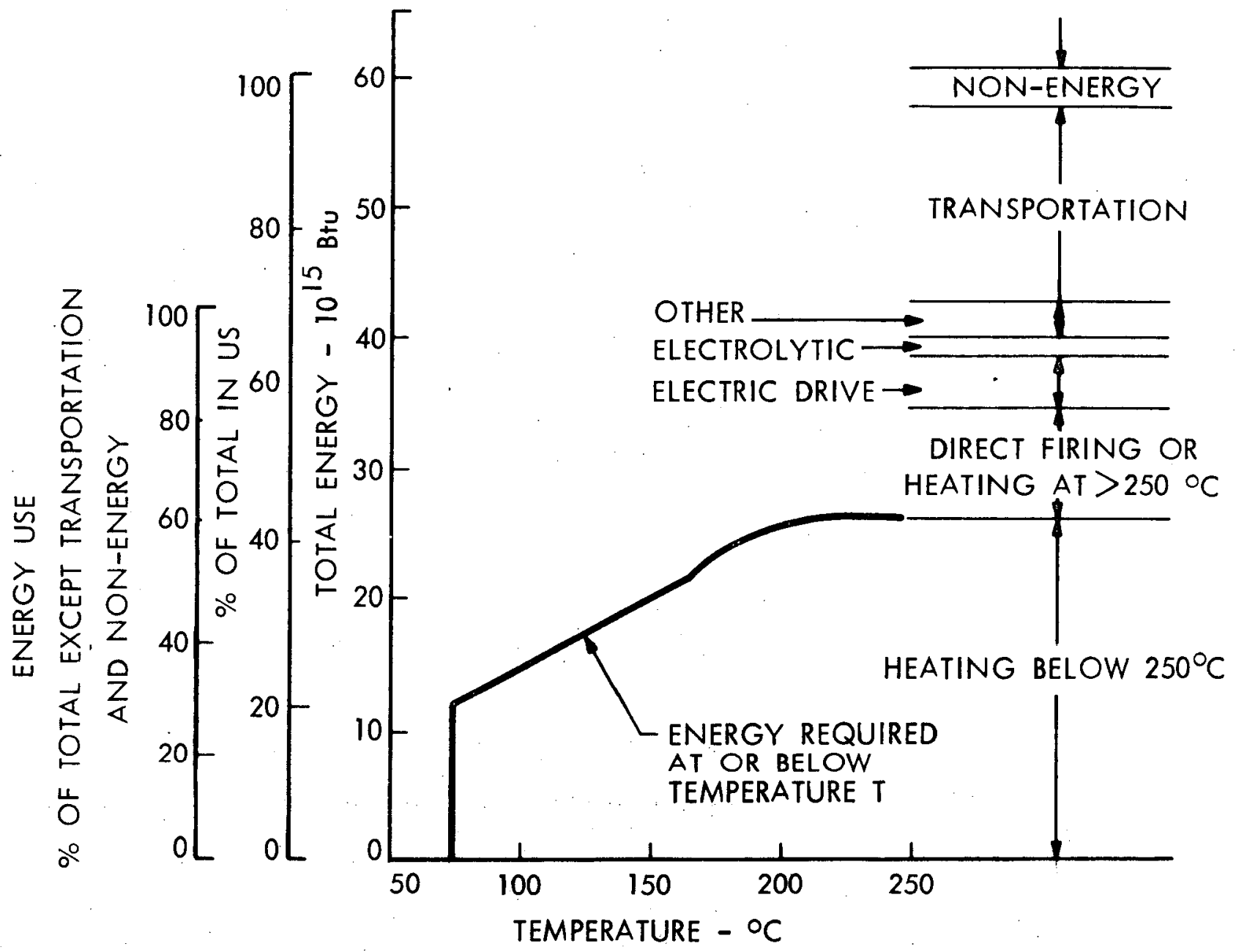

Fig. 3-2. Cumulative energy use as a function of temperature of of heating shown in relation to the total energy requirements in the United States (Ref. 3-2). 


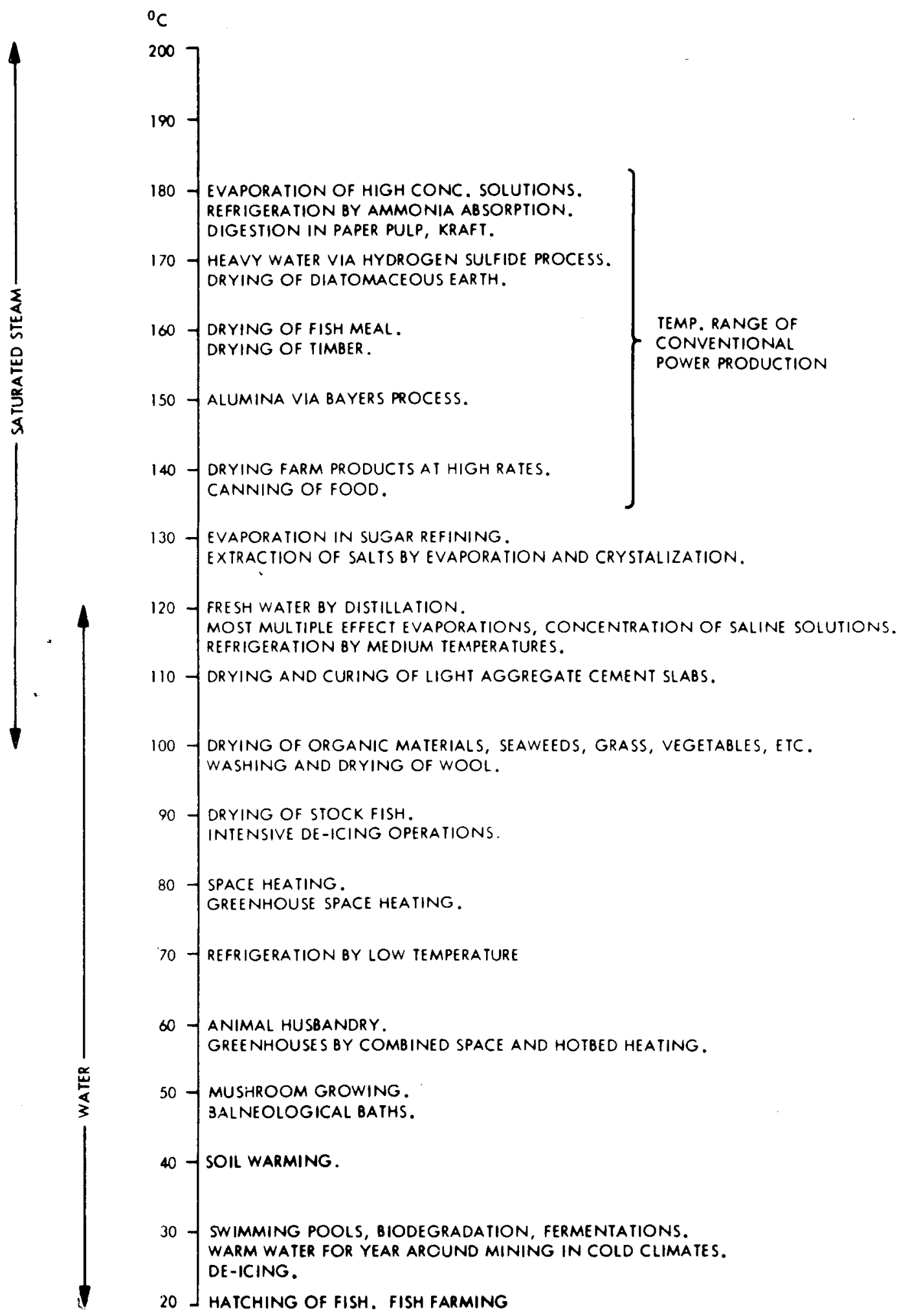

Fig. 3-3. Required temperature of geothermal fluids for various nonelectrical applications (Ref, 3-3). 


\section{DEVELOPMENT CONSIDERATIONS}

Although the potential for nonelectric geothermal applications is large the actual usage is small, less than the equivalent of a $100 \mathrm{MW}$ electric plant. Because geothermal heat is not transportable over large distances, the user must be located close to the geothermal energy resource. Historically, most nonelectric geothermal applications in the state are the result of individuals' taking advantage of a nearby geothermal resource in a "do-it-yourself" fashion. The nonelectric industry also is characterized by the need for a large number of relatively inexpensive, relatively low-flow-rate, shallow wells where the investment and risks are low.

As a part of the preparation of the Program Definition for the Development of Geothermal Energy for NASA, interviews were held in four nonelectric sectors:

- Industrial process heat.

- Commercial space and water heating.

- Residential space and water heating.

- Agribusiness.

A discussion of these applications and the users'views follows (Ref. 3-4).

\section{Industrial Processing}

Industrial process plants such as paper mills, sugar refineries, canneries, and other chemical and food processing plants currently use large amounts of fossil fuels. Each such plant is roughly comparable to a $50 \mathrm{MW}$ fossil-fuelfired electric plant. Many of these plants are located in rural areas of the western United States in order to be close to raw materials such as lumber, agricultural produce, and minerals. The utilization of geothermal energy in these plants in the future will strongly depend on the cost and availability of alternative energy sources. 
The conversion to geothermal energy in industrial applications requires replacing or supplementing existing fossil fuel equipment (such as boilers, driers, etc.). Because of the high mineral content of geothermal fluids, most applications will either have to transfer the heat from a geothermal brine to a working fluid such as purified water, or flash the brine and utilize the separated steam directly. The basic technology associated with the conversion is the same as that required for electrical power production.

Interviews indicate that a decision to convert to the use of geothermal energy or to use it in a new plant will be dependent on site-specific economic characteristics of the resource. The costs associated with plant locations are also inseparably tied to the cost of energy itself. The decision to use geothe rmal energy, therefore, not only includes the cost of geothermal energy but also the site-dependent availability and cost of such things as raw materials, services and utilities, water, transportation, taxes, labor, and site access. Although the availability of capital may not be a problem for an economically sound project, the current high cost of capital is, and biases the economics in favor of expanding existing facilities instead of constructing new ones.

\section{Commercial Space Heating}

Commercial space heating and cooling appears to be one of the more attractive applications for utilizing geothermal fluids. The extent of this application will depend heavily upon the resource-population interface since commercial buildings are typically located in urban areas. Some commercial buildings, such as military bases, may be located in more remote areas, but those establishments involved in business generally require proximity to population, transportation, and manufacturing centers. The temperature requirements for space heating a re low $\left(50-75^{\circ} \mathrm{C}\right)$. This fact greatly increases the probability of locating a nearby resource of suitable quality, particularly if near-normal-gradient utilization becomes economical. The temperature requirements for commercial cooling are somewhat higher $\left(100-125^{\circ} \mathrm{C}\right)$. This is still considered a low-to-medium temperature resource, but lowering the temperature requirements to match those of space heating would greatly increase the potential of the application. 
Commercial heating should be readily adaptable to geothermal since most existing buildings contain hot water or steam systems. In addition some utilities operate district heating systems in commercial downtown areas. Hot water technology is commonplace and hardware is generally commercially available. In most cases geothermal fluids will require either treatment prior to such use (urban drinking water is usually unsatisfactory for direct use) or transfer of the heat to a clean or treated fluid.

Interviews with commercial-development representatives indicate that the primary factor affecting the selection of geothermal energy is economic viability. Although a heating system is usually not the major concern of a commercial establishment, heating costs can be substantial. However, an equally important concern to the building owner is the reliability of the heating system. Owners of large buildings hesitate to experiment with new, unproven systems. Geothermal heating will find wide use only if it is shown to be economical and reliable.

\section{$\underline{\text { Residential Space Heating }}$}

The application of geothermal to residential development is primarily in the form of space heating and cooling and water heating, with space heating being the predominant usage. The applicability of geothermal energy to space heating is excellent. The temperature requirements a re low, a fact which will enable usage of the broad low grade resource base, and the demand is high. Residential heating accounts for roughly $30 \%$ of the total nonelectric energy usage in the United States. Hot water heating is also attractive, being a simple extension of hot water space heating. Water heating is a relatively constant requirement and is therefore ideal for geothermal energy application. It is also a significant portion (20-40 percent) of the space heating requirement. Space cooling could be attractive in residential use if equipment could be developed which could be powered by the hot water used for space heating. Unfortunately, present temperature requirements for absorption units are considerably higher. If low-temperature absorption refrigeration were achieved, space cooling during summer months would smooth out seasonal load fluctuations and would thus improve the economics of geothermal utilization. This 
would also allow a much broader market for geothermal energy in hot climates, where air conditioning is costly and space heating is relatively insignificant.

Although the applicability of geothermal energy to residential use is excellent, utilization involves a variety of market structures and implementation types. Current activity appears to be mainly small efforts by individuals.

Residential application is obviously very dependent on the resourcepopulation interface. Although some population shifts to geothermal energy may occur, these will be very slow. Building cities in remote areas primarily to utilize geothermal energy does not appear feasible, since a variety of developments must arise simultaneously, such as employment opportunity, transportation, shipping, etc. Comparison of population density and hot spring location shows a small resource-population interface.

A variety of applications have been accomplished in the United States and abroad. The district heating system of Reykjavic, Iceland is one of the largest and best engineered systems in existence. U.S. developments include one small district heating system in Boise, Idaho and numerous individual efforts. Implementation is very similar to commercial space heating with the exception of distribution systems. The mainstay of the housing market is the detached single family dwelling. This leads to low demand-density and large distribution requirement. This fact alone may render retrofitting of residential areas for geothermal energy prohibitively expensive.

\section{Agribusiness}

Greenhouse space heating appears to be an attractive application of nonelectric geothermal. Some greenhouses have already installed such systems and linterest in this industry appears to be quite high. Greenhouses are typically heated by natural gas. Recent price increases, together with lack of availability, have been serious problems to the industry. Many northern firms are going out of business and most of the expansion is occurring in southern regions, where energy requirements are much smaller. Greenhouses are simple structures and therefore relatively easily moved. Although 
greenhouse location requires a labor force, transportation, etc., they can be located relatively remotely. These factors facilitate relocation of greenhouse operations.

Although greenhouses are a natural for geothermal heating, the potential energy usage at present appears small. Increased transportation costs may favor greenhouse farming in northern areas, provided an inexpensive energy source is available.

Other potential applications include space heating for greater productivity in animal husbandry and open field heating for faster plant growth, longer growing seasons, and frost protection.

Implementation is essentially the same for greenhouse heating as for other space heating types. Both forced air and radiant systems can be used. Use in aquaculture can be direct when fluids a re clean; otherwise, heat exchangers are required to obtain fresh warm water in which the fish are cultivated. Open field agriculture can use geothermal water in underground pipes for soil warming or in sprinkler systems for frost protection. In most cases, usable systems for agricultural applications can be constructed, but continued effort must be expended to optimize present methods and to develop improved techniques for heat utilization.

\section{CURRENT DEVELOPMENT PLANS}

Very few nonelectric applications of geothermal energy are being considered in the state at this time. The main activities a re associated with the Bureau of Reclamation desalination project in the Imperial Valley and the ERDA - supported study at Susanville.

\section{Bureau of Reclamation}

The Bureau of Reclamation pilot plant at East Mesa in the Imperial Valley is investigating the feasibility of providing a source of fresh water for augmentation of the Lower Colorado River through desalting geothermal fluids underlying 
the valley. Five geothermal wells have been drilled and two desalting units installed. The units have been operated and have produced substantial quantities of high quality water. These investigations a re continuing (Ref. 3-5).

$\underline{\text { ERI)A }}$

The ERDA-supported Susanville Project is a study directed at the utilization of geothermal energy of the Susanville-Honey Lake area to build an economic base for a community. The total system under study is composed of a thermal energy nodule in the Susanville area, a thermal energy module and possibly a thermal-electric module in the mid-valley area, and one or more thermal-electric modules in the Wendel-Amedee KGRA. A distribution network would distribute both thermal and electric energy to agricultural and industrial facilities throughout the Susanville-Honey Lake area. Geoscience and drilling investigations are being supported by the Bureau of Reclamation (Ref. 3-6).

ERDA is seeking to further the study of nonelectric applications. It has recently is sued a program announcement inviting proposals covering engineering and economic studies of nonelectric applications of geothermal heat associated with hydrothermal resources at temperatures less than $150^{\circ} \mathrm{C}$. The primary interest is in (1) reservoir-specific or (2) general functional applications studies lealing with industrial processing, agricultural uses, and space/water heating and cooling for commercial and residential buildings.

R EFERENCES

3-1. Energy Alternatives for California - Paths to the Future. Rand Document R-1793-CSA/RF, Dec. 1975.

3-2. Reistad, G. M., Analysis of Potential Nonelectrical Applications of Geothermal Energy and Their Place in the National Economy, Lawrence Livermore Laboratory Report UCRL-51747, 1975.

3-3. Lindal, B., in Geothermal Engineering (C. H. Armstead ed.) UNESCO Press, Paris, 1973.

3-4. Appendix F, Program Definition for the Development of Geothermal Energy, Volume III, Jet Propulsion Laboratory Report 5040-6, August 29, 1975. 
3-5. Fulcher, M. K., Overview of Reclamation's Geothermal Program in Imperial Valley, Proceedings: Conference on Research for the Development of Geothermal Energy Resources, Pasadena, Calif., Sept. $23-25,1974$.

3-6. Susanville Geothermal Energy Project, Quarterly Report, Jan. 8, 1976, City of Susanville.

3-7. Geothermal Energy Program, Program Research and Development Announcement, "Engineering and Economic Studies of Nonelectric Applications of Geothermal Heat, "PRDA DGE-76-1, closing date: May 3, 1976. 
SECTION IV

THE GEOTHERMAL RESOURCE DEVELOPMENT PROCESS

\section{SUMMARY}

No less than 16 state agencies, 9 federal agencies, and at least 3 local agencies (in each county) have an interest or role in the administrative process associated with the total geothermal resource development. Since none of these agencies has the duty of coordinating the functions of all the agencies, it is left to the geothermal developer to navigate a course through the administrative process, which can be both time-consuming and discouraging even for the developer with abundant capital and legal resources. The complexity of this administrative process - as well as the absence of formal arrangements whereby intergovernmental policy conflicts can be expeditiously resolved - is a key factor in delaying geothermal development. (1)

This section identifies the cognizant agencies, the necessary activities, and the administrative procedures related to geothermal power plant development in the State of California for both electric and nonelectric applications on federal and non-federal land. In the subsection (pg. 4-2) that follows the responsibilities of the public agencies involved in the geothermal development process are shown.

A general overview of the development activities and administrative procedures is presented (pg. 4-14). In the two subsections that follow, this generalized overview is applied to developments on federal (pg. 4-21) and non-federal lands (pg. 4-29), respectively. Estimated development timelines are presented as are flowcharts depicting administrative processing time requirements.

(1) It should be noted that, unlike the exploration phase, the power plant development phase is the responsibility of the Energy Commission, as stated in AB 1575. The Energy Commission was given lead agency responsibility for coordinating and ensuring implementation (to the extent feasible) of requirements of all state and local agencies who would have some approval authority over a proposed facility but for the commission's preemptive authority. 
The results indicate that, on federal land in California, development of an electric power plant is estimated to require 9 years from the time the decision is made to explore to the time power would be on-line. For a nonelectric application on federal land, the estimated time frame would be 5 years.

Corresponding results for private and state lands are estimated to be approximately 8 years for an electric power plant and approximately 4 years for a nonelectric application. The primary reason for the shorter estimated development time on nonfederal land is that less time would be required for leasing land and less time would be required for the EIR process than for the EIS process (when required under CEQA and NEPA, respectively).*

GOVERNANCE OF GEOTHERMAL RESOURCE DEVELOPMENT

\section{INT RODUCTION}

Geothermal development in California requires a number of government permits and approvals by local, state, and federal agencies. The nature of the ownership of the land under which the resource deposits a re located largely determines which cognizant agencies are involved in the process. However, the fact that a parcel of land is federally owned does not mean that the development of the resource thereon is exclusively governed by federal regulations. *

Identification of which public agencies a re involved in the geothermal resource development process and for what purpose is summarized in Table 4-1. In that table the 16 state agencies, 9 federal agencies, and 3 local agencies are presented in a format that shows their corresponding areas of interest.

\footnotetext{
* The requirement for an Environmental Impact Report (EIR) arises from criteria set forth in the California Environmental Quality Act (CEQA), whereas the requirement for an Environmental Impact Statement (EIS) arises from criteria set forth in the National Environmental Protection Act (NEPA).

*** For example, local environmental quality standards, such as those for air and water quality, apply to development upon federal lands when those standards are more stringent than federal standards. However, it is the federal agencies that enforce these standards.
} 
Table 4-1. Public agencies involved in the geothermal resource development process

\begin{tabular}{|c|c|c|c|c|}
\hline 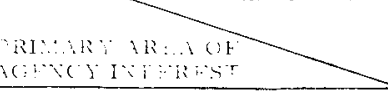 & CALIFOR $\because A$ & $F F I D A R \backsim$ & RECHONA OR LOCAL & NIGHAORING STATES \\
\hline Land $u=x$ & Staw Land Commision & $\begin{array}{l}\text { 13partment of the Interior } \\
\text { Burvau of Lanc Management }\end{array}$ & County Hlannine Wepartnient & Yevada \\
\hline 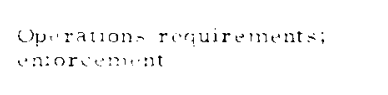 & Wivition of Oil and Gas & $\begin{array}{l}\text { 1)epartment of the Interior? } \\
\text { U.S. Geological Survey }\end{array}$ & & $\begin{array}{l}\text { Weothermal resources } \\
\text { development is under the State } \\
\text { tater Enginer. On non- } \\
\text { federal land, drilting can be }\end{array}$ \\
\hline $\begin{array}{l}\text { Air cuility stanciarcis; } \\
\text { inforcmint }\end{array}$ & Air Ri:sources Bratd & & $\begin{array}{l}\text { Local Air Pollution Control } \\
\text { listrict }\end{array}$ & $\begin{array}{l}\text { conducted without obtaining a } \\
\text { permit, atthough most opera- } \\
\text { tions do obtain both a permit }\end{array}$ \\
\hline $\begin{array}{l}\text { Water protection; dischargu } \\
\text { recumrenunt: }\end{array}$ & $\begin{array}{l}\text { State Water Resources Control } \\
\text { Board }\end{array}$ & & $\begin{array}{l}\text { Regional Water Quality } \\
\text { Control Board }\end{array}$ & $\begin{array}{l}\text { and a drilling license from the } \\
\text { State. }\end{array}$ \\
\hline Fish and wildtice protection & Department of Fish and Came & $\begin{array}{l}\text { Department of the Interior/ } \\
\text { U.S. Fish and Wildlife } \\
\text { Servict. }\end{array}$ & & $\begin{array}{l}\frac{\text { Orejon }}{\text { Regulatory framework }} \\
\text { divides development into three }\end{array}$ \\
\hline Solid waste disposal & $\begin{array}{l}\text { Solid Waste Management } \\
\text { Board }\end{array}$ & & & $\begin{array}{l}\text { phases: pre-exploration, } \\
\text { exploration and production. } \\
\text { The approval process is } \\
\text { similar to that in California }\end{array}$ \\
\hline $\begin{array}{l}\text { Water resources } \\
\text { dweiopment }\end{array}$ & $\begin{array}{l}\text { Department of Water } \\
\text { Resources }\end{array}$ & & & $\begin{array}{l}\text { except that in actuality the } \\
\text { local governiments have far } \\
\text { less influence over develop- }\end{array}$ \\
\hline $\begin{array}{l}\text { Forest watershed } \\
\text { protection }\end{array}$ & Division of Forestry & $\begin{array}{l}\text { Devartment of Agricultur } \\
\text { Forest Service }\end{array}$ & & $\begin{array}{l}\text { ment (aside from the Heating } \\
\text { Districts in rilamath Falls). } \\
\text { The State Department of }\end{array}$ \\
\hline $\begin{array}{l}\text { Lutra-cowernmental } \\
\text { coordination }\end{array}$ & Geothermal Resources Board & $\begin{array}{l}\text { Geothermal Environmental } \\
\text { Advisory Panel }\end{array}$ & & $\begin{array}{l}\text { Environmental Quality is } \\
\text { instrumental in geathermal } \\
\text { development. Its primary }\end{array}$ \\
\hline Pritution contro! & & $\begin{array}{l}\text { Environmental protection } \\
\text { Agency }\end{array}$ & & $\begin{array}{l}\text { focus is on solid waste disposal } \\
\text { and discharge of pollutants into } \\
\text { the air or public waters. Juris. }\end{array}$ \\
\hline $\begin{array}{l}\text { Energy rusearch and } \\
\text { checiopment; conservation } \\
\text { of renourens }\end{array}$ & $\begin{array}{l}\text { State Energy Resources } \\
\text { Conservation and Dewelopment } \\
\text { Commision }\end{array}$ & $\begin{array}{l}\text { Energy Research and } \\
\text { Development Administration }\end{array}$ & & $\begin{array}{l}\text { diction over wells is vested in } \\
\text { the Department of Geology and } \\
\text { Nineral Industries. }\end{array}$ \\
\hline $\begin{array}{l}\text { Siting approvat of power } \\
\text { plants; rate regulating }\end{array}$ & $\begin{array}{l}\text { California Public tilities } \\
\text { Commission, CERCDC }\end{array}$ & Federal Power Commission & & $\frac{\text { Arizona }}{\text { Permits for geuthermal }}$ \\
\hline $\begin{array}{l}\text { Cikarininouse ior } \\
\text { eringonmental impact ruports }\end{array}$ & $\begin{array}{l}\text { Covernor's Oifice of Planning } \\
\text { and Research }\end{array}$ & & & $\begin{array}{l}\text { Permits for Reuthermal } \\
\text { drilling on private. state, and } \\
\text { federal land must be obtained } \\
\text { from the Oil and Gas Commis. }\end{array}$ \\
\hline $\begin{array}{l}\text { Occupational health and satety } \\
\text { siandaris; enorecment }\end{array}$ & $\begin{array}{l}\text { 1)epartment of Industrial } \\
\text { Relations }\end{array}$ & $\begin{array}{l}\text { O.cupational Safity and Health } \\
\text { Adninistration }\end{array}$ & & $\begin{array}{l}\text { sion. Conditional use permits } \\
\text { from local agencies have not } \\
\text { been required for exploration }\end{array}$ \\
\hline $\begin{array}{l}\text { Rifuloactice waste disposal } \\
\text { crintrol }\end{array}$ & Department of Health & & & activities to date. \\
\hline $\begin{array}{l}\text { Pablic seculrities - issuance } \\
\text { anci truting repulation }\end{array}$ & Corpurations Commisaton & $\begin{array}{l}\text { Securities and Exchanue: } \\
\text { conmmission }\end{array}$ & & \\
\hline Property tax assessment & State lioard of Fqualization & & & \\
\hline
\end{tabular}


The following paragraphs and tables briefly describe the responsibilities of the key agencies. A more detailed description of the procedures by which these agencies implement the regulatory structure of their respective jurisdictions is presented in Appendix A.

\section{OVERVIEW OF ENERGY REGULATION}

A general discussion of energy regulation is presented here to provide a common basis for later discussions which describe the responsibilities of the public agencies administering the regulations within each jurisdiction (refer to Table $4-2$ ).

There are three basic objectives toward which energy regulation is directed:

- To encourage development of economical energy supplies.

- To insure, by sound land management, wise and efficient use of public lands and the energy resources underlying them.

- To protect health and safety, and to protect and enhance environmental quality.

\section{Economic Regulation}

The ways by which energy regulation is accomplished include:

- Issuance of permits to serve new markets and areas.

- Enforcement of antitrust regulations and promotion of competition.

- Regulation of rates, prices, and profits.

- Review of financial status and regulation of certain security issuances and mergers of energy corporations.

- Establishment of terms under which energy commodities are extracted from public lands.

- Taxation (i.e., income, property, depreciation policy, depletion policy). 


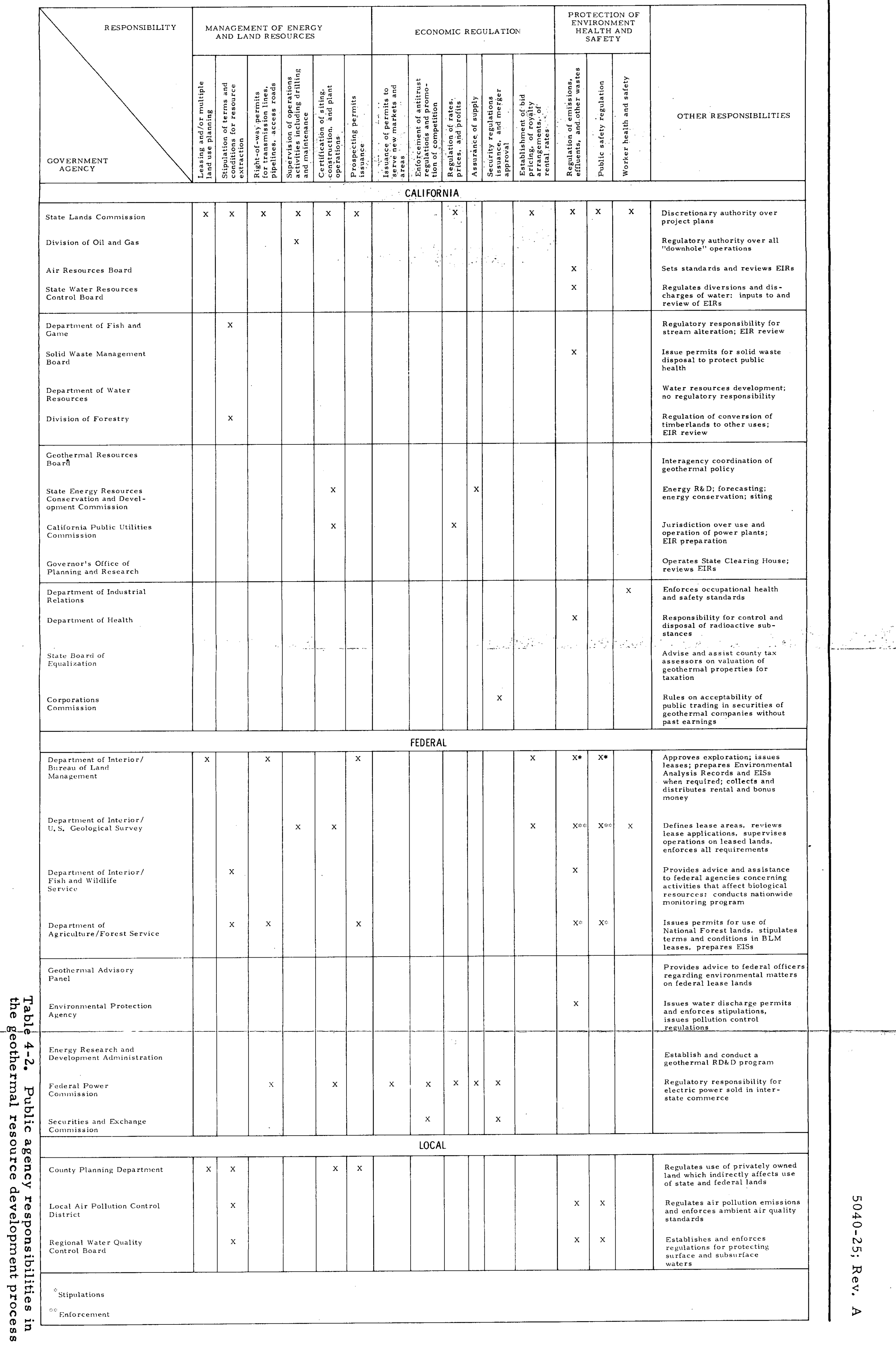





\section{Management of Energy and Land Resources}

The management of public resources includes:

- Awarding leases.

- Establishing terms and conditions under which resources are extracted from the land.

- Land use planning.

- Granting rights-of-way permits for transmission lines and pipes.

- Supervising operations conducted under public leases.

- Certifying the siting, construction, and operation of power plants.

- Resource assessment.

\section{Protection of Environment, Health, and Safety}

There are three aspects of the overall policy objective of protecting the environment, health, and safety. They are emissions, effluents, and other wastes; public safety; and worker health and safety.

- Emissions, effluents and other wastes are regulated for purposes of protecting public health and welfare, and in order to preserve and enhance environmental quality.

- Public safety regulations are designed to protect the public from the effects of abnormal occurrences (e.g., major nuclear power plant accidents, explosions at liquified natural gas facilities, and dam failures). A distinction is made between regulations designed to protect the public from the effects of accidents (i.e., public safety regulations) and those designed to protect the public from the effects of normal operations (i.e., public health regulations) which are, in effect, controls on emissions, effluents, and other wastes.

- Worker health and safety regulations are intended to protect the health and safety of workers employed in energy activities. These

\footnotetext{
*Protection of the environment also includes considerations for erosion, topographic impacts, vegetation removal, aethetics, visual pollution, fish and wildlife effects, etc.
} 
regulations are distinguished from those designed to protect public health and safety. Workers will generally be allowed exposure to greater risks than the public, on the grounds that workers incur such risks voluntarily whereas the public has no control over its exposure. In addition, workers will be exposed to a wider variety of hazards than will the public owing to the worker's proximity to sources of harm.

\section{STATE REGULATORY AGENCIES}

The agencies which are either directly or indirectly involved in the development process in California are identified in Table 4-1. In the first column of the table, a key word identification is given for the agencies' primary area of interest. * In the second and third columns, the state, federal, and local agencies concerned with this area of interest, and involved in geothermal development, are identified. A more specific identification of agency responsibilities is given in Table 4-2.

It will be noted that 16 state agencies are involved in the development process. Of these, 9 regularly play an active role:

- State Lands Commission

- Division of Oil and Gas

- Air Resources Board

- Water Resources Control Board

- Department of $F$ ish and Game

- Geothermal Resources Board

- Public Utilities Commission

- Energy Resources Conservation and Development Commission

- Office of Planning and Research

* In some instances a key word is not totally descriptive; however, such a mechanism allows the general correlation of governmental agency responsibilities across jurisdictional boundaries. 
Although there are a number of agencies with cognizance over the development process, interagency coordination is facilitated by the Geothermal Resources Board which addresses key policy issues. (Refer to Appendix A for a more detailed discussion of the Geothermal Resources Board.)

In addition to the interagency relationships, intergovernmental coordination is required throughout the development process. In the statelocal relationship, the coordination and dialogue is generally effective. A major problem may arise, however, when there is a difference in development policy between the two levels of government, and may result in delays to the development process.

Intergovernmental relationships between state and federal government agencies are not as effective as those between local and state agencies. The key reason is that new interagency relationships and channels of communication have had to be established to carry out the respective missions of the agencies." The channels of communication between state and local entities are already established. Therefore, in addition to policy differences which arise, there are communication breakdowns which also delay the development process.

\section{FEDERAL REGULATORY AGENCIES}

Table 4-1 is arranged to show the correspondence of areas of interest between state, federal, and local agencies. A specific designation of agency responsibilities is presented in Table $4-2$ and a more detailed description of each agency appears in Appendix A.

Of the nine federal agencies identified in Table 4-1, five are actively involved in the geothermal development process in California: ${ }^{* * *}$

* In some areas, such as Inyo County, an informal group of federal, state, and local officials meet regularly to discuss geothermal development matters.

** Since there are no geothermal plants in the state located on federal land, the future role of the Federal Power Commission is unclear at this time as to whether its jurisdiction will, as applied, be limited to interstate matters and matters not covered by state regulations. 
- Department of Agriculture/Forest Service

- Department of the Interior/Bureau of Land Management

- Department of the Interior/U.S. Geological Survey

- Department of the Interior/Fish and Wildlife Service

- Geothermal Environmental Advisory Panel

Interagency coordination is accomplished by formal cooperative agreements, by informal procedural agreements, and by interagency panels.

Currently, there are two formal cooperative agreements between the Bureau of Land Management and the U.S. Geological Survey.

- WO-55, dated August 6, 1975, which sets out the procedures for preparation of environmental reports concerning geothermal energy (see Appendix A, Attachment (a)).

- WO-56, dated August 29, 1975, which sets out procedures for mutual cooperation in leasing and managing the operation of geothermal development on federal lands (see Appendix A, Attachment (b)).

There is a Tripartite Agreement between the Bureau of Land Management, the U.S. Geological Survey, and the Fish and Wildlife Service which will facilitate leasing and land management procedures (see Appendix A, Attachment (c)).

In addition to the formal and informal interagency agreements, the re is an interagency Geothermal Environmental Advisory Panel which advises responsible officers regarding environmental problems with respect to development on federal leased land (see Appendix A, Attachment (d)).

Since federal interagency coordination has only recently (i.e., in late 1975) been finalized in some respects and is still being formulated in others, it is likely that the absence of well defined processes has led to the delays in developments on federal lands in California prior to the above-cited efforts. 


\section{LOCAL REGULATORY AND REVIEWING AGENCIES}

The three main regional/local agencies involved in the development process are as follows:

- County Planning Departments

- Air Pollution Control Districts

- Regional Water Quality Control Boards

As can be seen in Tables 4-1 and 4-2, planning departments regulate the use of privately owned land through the practice of zoning and the issuance of conditional use permits. In order to commercially develop land for geothermal applications, a contiguous area must be unitized for development. Because private lands, state lands, and federal lands are frequently intermixed, local policy regarding private land can strongly influence the extent of development on adjacent public lands.

Local Air Pollution Control Districts regulate air pollution emissions from stationary sources and enforce ambient air quality standards with the approval of the state Air Resources Board. In instances when local standards are more stringent than federal standards, which is generally the case in California, then development on public lands must comply with local rules and regulations.

Regional Water Quality Control Boards are regional bodies under state control which establish and enforce regulations for the protection of surface and subsurface waters. They issue waste discharge requirements for any proposed activity which could discharge waste substances into the state's rivers, lakes, and streams. 


\section{GEOTHERMAL REGULATION IN NEIGHBORING STATES}

At first glance, administrative requirements for the development of geothermal resources in other states are not very different from those in California. " In effect, however, the differences are extensive because of the following factors:

- The extent to which California has delegated power to county and local government agencies with respect to land use and environmental regulation as compared to neighboring states.

- Agricultural, lumbering, residential and/or recreational applications are frequently in direct competition with geothermal applications and this, more frequently in California than elsewhere, results in major policy conflicts.

- The quantity of geothermal activity in California is far greater than that in the rest of the nation taken together.

- The longer history of geothermal industry in California has éngendered a need for a more detailed regulatory framework.

Nevada

In Nevada, geothermal resources development authority has been vested in the State Water Engineer. Drilling merely requires a license from the state to perform such operations. Permits are generally obtained, but not required, for the appropriation of ground water.

Because of the benign regulatory framework with respect to private lands in Nevada, extensive exploratory drilling has taken place, primarily on private lands.

* See article by Tracy Lyons, reprinted from Geothermal Energy, on the administrative requirements for the development of geothermal resources in Oregon: Appendix B. 
Oregon

The regulatory framework in Oregon for geothermal resource development is similar to that in California. That is, a number of state and local agencies are involved in the administrative paperwork processing. However, in effect the local agencies do not exercise the powe $r$ which corresponding California local government agencies do with respect to land use and environmental regulation.

The key agency in Oregon responsible for environmental regulation is the Department of Environmental Quality (DEQ). Its primary focus is on solid waste disposal and discharge of pollutants into the air or public waters. Juris diction over geothermal wells is vested in the Department of Geology and Mineral Industries.

Since there has been very limited deep drilling (one well in 1975 and two wells in 1974) in the state to date, DEQ has not adopted a specific position with respect to geothermal development per se.(2) However, existing legislation, which was revised in 1975 , (3) separates geothermal development into three phases: pre-exploration, exploration, and production. This segmentation enables each phase to be assessed with respect to the impact it will have on the environment (i.e., exploration activity is not evaluated as if it would lead to a power plant; that aspect is considered at the time of a production phase request).

(1) An exception to this statement should be noted with respect to the Heating Districts' authority, in the Klamath Falls area, pertaining to the use of thermal waters for space heating. Data on the Heating Districts was not available at the time of this writing.

(2) Janet McLennan, Assistant to the Governor, Natural Resources, telephone interview on February 9, 1976.

(3) Enrolled Senate Bill 883 and Enrolled House Bill 2040 approved by Governor June 30, 1975. 


\section{Arizona}

In Arizona, regulation of geothermal drilling is vested in the Oil and Gas Commission. Developers on private, state, or federal land must file a request for a drilling permit with the Commission. (No problem has developed over federal lessees' filing a request with the Commission because, to date, the Commission has not denied such a request.)

Conditional use permits have not been required to date for exploration activities. However, the only ${ }^{*}$ geothermal tests conducted in the last 3 years have been on private lands (none of which were in close proximity to any community).

Owing to a recent Arizona Supreme Court decision (FICO vs. Pema Mining Company), which held that ground water which contains elements of the land or mineral byproducts must be sold at public auction, there has been no exploration activity on state lands.

\section{OVERVIEW OF DEVELOPMENT ACTIVITIES AND ADMINISTRATIVE PROCEDURES}

General development of both electric and nonelectric applications, from the initial commitment to explore through plant construction, can be considered to generally consist of four major activities:

- Leasing and Administrative Processing.

- Exploration and Reservoir Assessment.

- Drilling and Reservoir Evaluation.

- Plant Design, Construction, and Initial Operation.

*William Allen, Oil and Gas Commission, Conservation Division. 
Elements of the above four activities can be conveniently grouped into two phases: (1) Land Acquisition and Exploration and (2) Development and Production, as shown in Fig. 4-1. This model timeline shows the phasing of activities throughout the development cycle including the major decision points of commitment.

Leasing and Administrative Processing activity includes such elements as acquiring or leasing the land, obtaining the various required permits and approvals (at all government levels) to explore and drill, processing the required environmental reports, and obtaining siting approval and plant certification (for an electric power plant application). The scope of agency involvement in geothermal development in California, as described in the preceding subsection (Governance of Geothermal Resource Development, page 4-2), makes the execution of this activity very complex and time consuming. Summarized in Table 4-3 for federal, state and private lands are the agencies involved and their procedural requirements in each phase of the development cycle.

Exploration and Reservoir Assessment includes performing a continuing series of exploratory techniques (e.g., geological, hydrological, geochemical, and geophysical) to assess the potential reservoir. Drilling during this activity is limited to shallow temperature gradient holes less than 150 meters (500 feet) deep.

Drilling and Reservoir Evaluation activity leads to field development. Early in the cycle, activities include drilling, completing, and flow testing the first deep well (wildcat well) plus a varying number of additional deep wells for the purpose of evaluating the reservoir (i. e., determining that it potentially contains a suitable, concentrated deposit of geothermal heat and that the energy can be extracted in economically and environmentally feasible quantities). Drilling of all additional wells, to meet the energy requirements of the plant, is performed later in the cycle. 


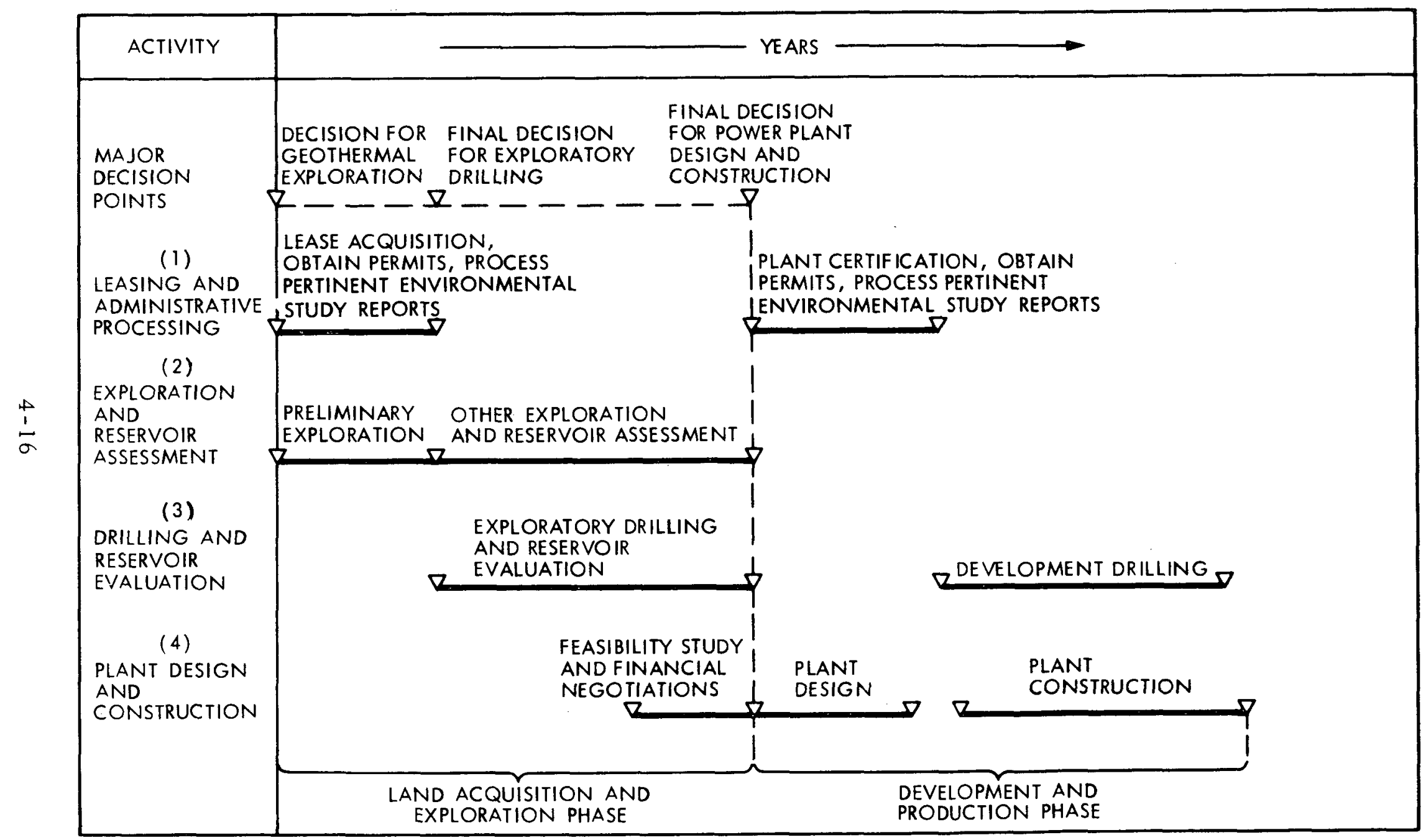

Fig. 4-1. Geothermal plant development model timeline 


\section{Table 4-3. Overview comparis on of geothermal development administrative procedures in the State of California*}

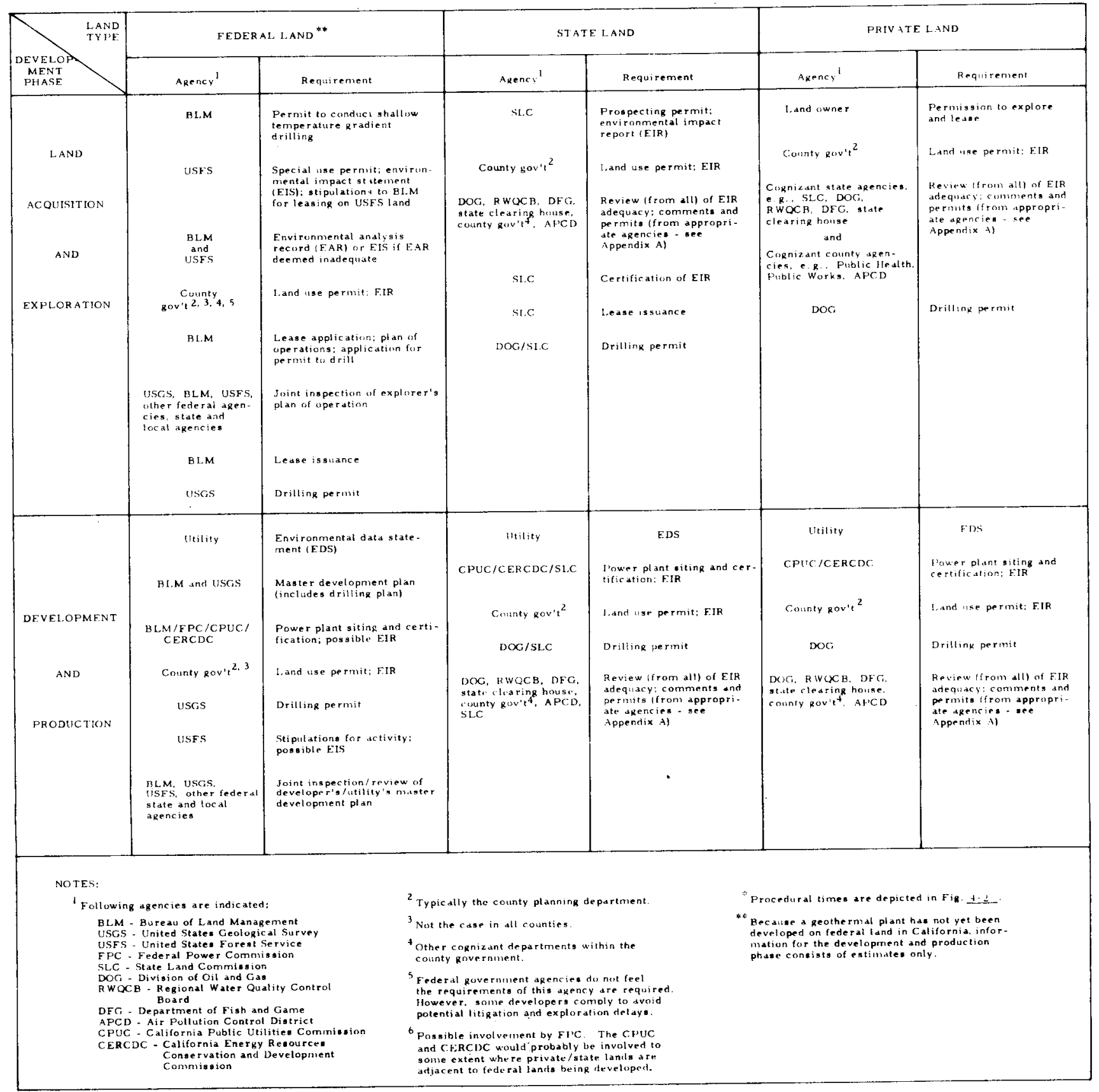


Plant Design and Construction activity utilizes data derived from the other activities to perform the plant feasibility and design studies. Once certified, the plant is constructed and operation is initiated. The fashion in which the elements of the four major activities would be expected to interact with each other during the cycle is illustrated in Fig. 4-2. The cycle starts with a decision to proceed with geothermal exploration. Permits and approval from the appropriate agencies are obtained, and preliminary resource assessment is performed to assess the area and locate prospective sites for deep drilling. A decision is made to proceed with this drilling if the data resulting from this preliminary exploration a re favorable.

In order to deep drill, the explorer must first have obtained the leases (the leasing process for federal, state, and private lands is discussed in detail in the next two subsections).

The feasibility study considers various power plant designs and establishes economic viability. This study utilizes reservoir evaluation data (including geothermal fluid chemical analyses) along with heat exchanger tests in selecting the appropriate conversion cycle and size of plant.

The financial and operating arrangements a re negotiated between the producer and user organizations. A decision to start plant development requires not only establishment of reservoir lifetime and energy potential but also establishment of economic viability for the proposed plant. Thus, data must be available for projecting reliability, downtime for maintenance, pollution control requirements, and other factors affecting cost and availability. * (A key point to consider in future geothermal development is that these data are required 5 years before a plant enters operation.)

\footnotetext{
*Availability refers to the percentage of time the generating plant can be "on-line" (i. e., not shut down for maintenance or repair).
} 


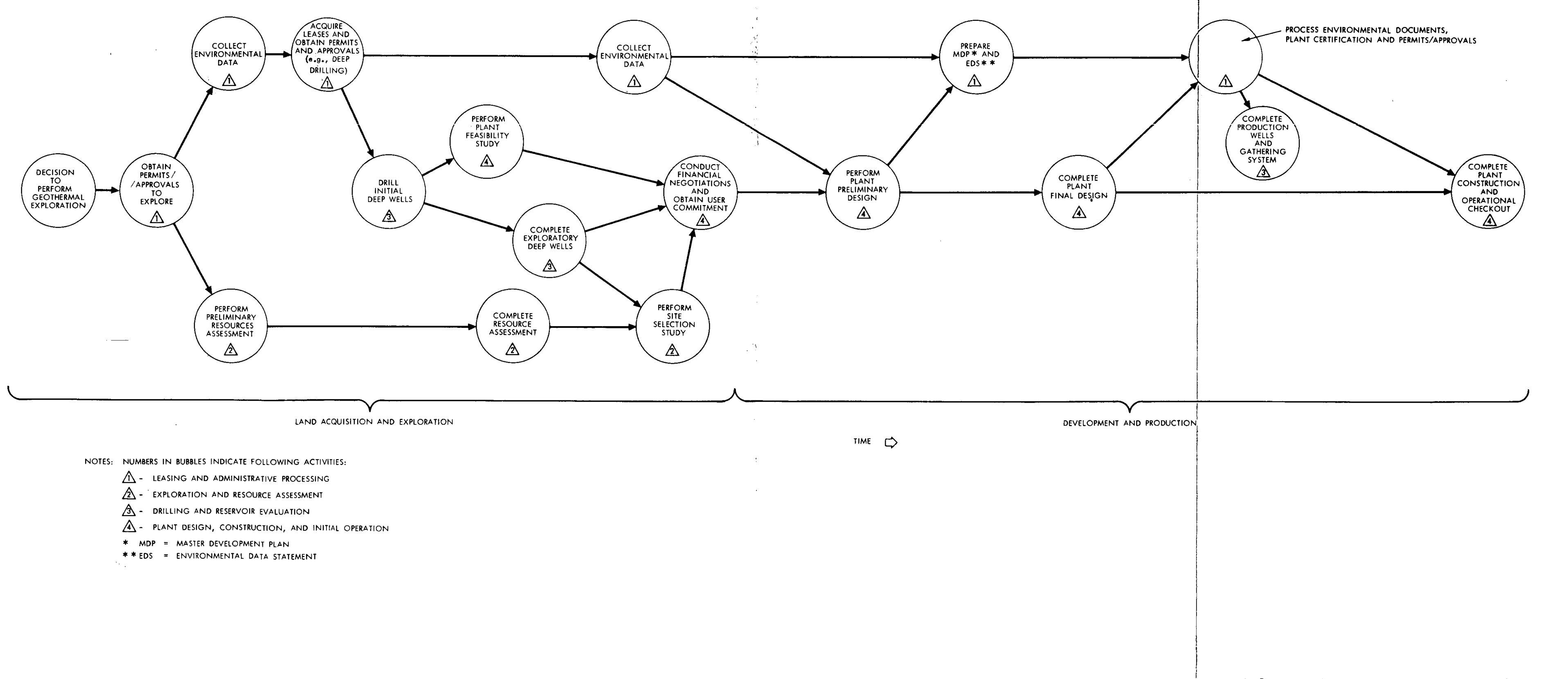



Once a decision is made to proceed with plant design and construction the cycle shifts from the Land Acquisition and Exploration Phase to the Development and Production Phase. During the preliminary plant design the plant cycle design is firmed up and long-lead-time items such as turbines and generators are ordered. This is followed by detailed plant design. During this period, procurement of sundry equipment to match the long-lead-time items is initiated, the master development plan (MDP, federal land only) and the Environmental Data Statement (EDS) are produced and submitted so that the necessary environmental documents may be prepared and permits and approvals obtained.

Drilling the production wells to complete field development is initiated after all permits are obtained and plant certification is approved. 'The field development is performed in parallel with the plant construction, and is timed so that the last wells and gathering system are completed a few months prior to completion of the plant.

GEOTHERMAL DEVELOPMENT ON FEDERAL LAND IN CALIFORNIA

FEDERAL LAND LEASING PROCESS

Two types of leases are issued for federal lands: (1) noncompetitive leases for lands outside of any Known Geothermal Resource Area (KGRA), and (2) competitive leases is sued by competitive bidding for lands within a KGRA.

Typically, before attempting to acquire either type of lease, the explorer would file an application for a Notice of Intent to Conduct Geothermal Resource Exploration ("Notice of Intent") on lands under BLM jurisdiction. The notice allows the applicant to go on the land and conduct preliminary exploration (including the drilling of shallow temperature gradient holes). The Notice of Intent is only used where lands are administrated by the BLM; on Forest Ser-. vice Land a Special Use Permit is required. Both the Bureau of Land Management (BLM) and the Forest Service have jurisdiction over large amounts of land in California, but, for purposes of this report, BLM is assumed to be the agency 
having jurisdiction (only minor variations exist for the Forest Service lands). Time to obtain approval to conduct the geothermal exploration can be as much as 30 days.

After preliminary exploration has indicated that deep drilling is appropriate and necessary the explorer would file a non-competitive lease application on any land subject to the geothermal act or if in a competitive area a nomination could be filed if the lands have not as yet been scheduled for sale. BLM is responsible then for preparing an environmental analysis record (EAR) for the purposed activities on its lands and a joint or separate EAR may be made by the land management agency if other than BLM. Technical inputs would be obtained from various federal agencies such as the U.S. Geological Survey (USGS) and the Fish and Wildlife Service, as well as state and local agencies. During the EAR preparation the explorer would most likely continue carrying out the preliminary exploration.

If a District Manager or State Director of BLM determines that the EAR is an adequate statement and no EIS is required BLM then determines from a technical examination if a non-competitive lease should be issued or a competitive sale should be held and the terms and conditions to protect the environment and to insure that a applicable state and local standards are complied with. Should the director (BLM) in Washington, D. C. confirm the EAR recommendation that an EIS is necessary he will direct an environmental impact statement (EIS) be prepared by the State Director of the bureau with participation of pertinent local and state agencies. Based on the EIS and a technical evaluation the bureau will determine whether or not a non-competitive lease should be issued or a competitive sale be held for the proposed geothermal project.

\section{DEVELOPMENT TIMELINES FOR FEDERAL LAND}

\section{Electric Application}

An estimated timeline for development of a geothermal electric power plant on federal land in California, based on the existing framework of technological, environmental, economic, logistical, and institutional constraints, 
is shown in Fig. 4-3(a). A cycle time of 9 years was estimated assuming (1) development on a previously unexplored field and (2) acquisition of the land through competitive leasing. The assumptions underlying the timelines are summarized in Table 4-4.

A second-generation plant developed on a known reservoir, under the existing framework of constraints, is estimated to require approximately 7 years. This estimate is based on the following assumptions: (1) the lease is available, (2) the exploratory drilling requirements are less extensive because the reservoir's characteristics have been essentially proven, and (3) the plant certification approval process would require less time.

It should be noted that while the leases are being processed, RFPs would probably be issued for the exploratory $\mathrm{d}$ rilling if the developer did not possess his own rigs. The drillers are chosen by the time the leases are let. The contract is signed and funds committed at the final decision for exploratory drilling. Also, at this decision point, the drilling plan is submitted to the USGS, which reviews it from a safety aspect. The review takes about 1 to 3 months and is conducted in parallel with obtaining additional permits for rig mobilization. The site is prepared and the rig mobilized during the following month.

Drilling time per well can vary from 2 weeks to 6 months, depending on the terrain, depth of drilling, and underground formation. For example, in The Geysers, 3 months might be required to drill and test a well whereas in the Imperial Valley a well might be drilled and tested within a few weeks.

Flow tests during the reservoir evaluation are conducted to study reservoir lifetime, porosity, and permeability in order to establish the usable energy potential of the reservoir. The duration of this test is defined by the utility or the investing parties. The tests might involve an 8 -month test for a few wells, or as little as a few weeks in an established field.

Construction of the plant will generally be delayed a certain length of time to provide a buffer in case of difficulties or in case the adequacy of the resource assessment is questioned during drilling. 


$$
4
$$

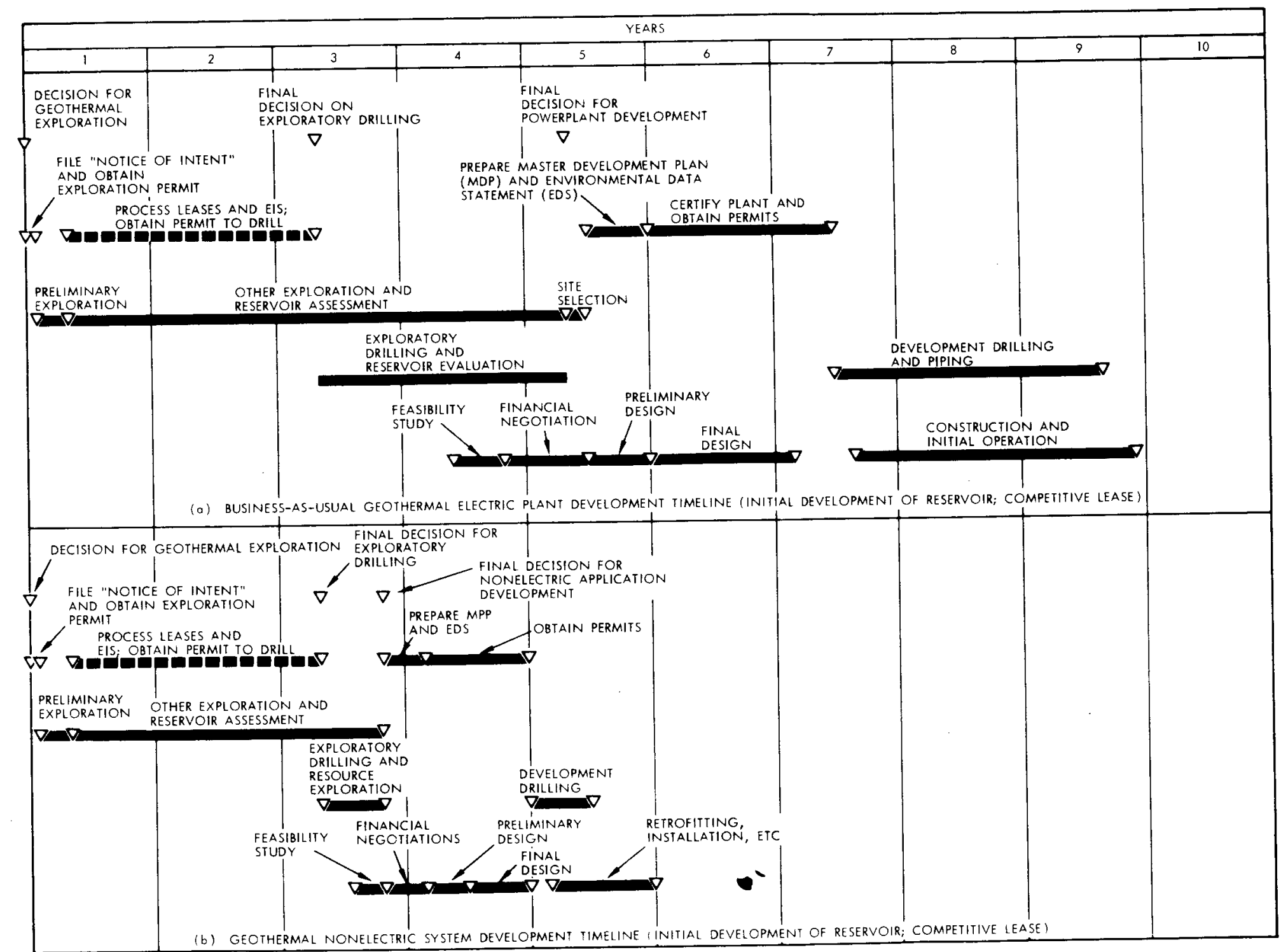

Fig. 4-3. Estimated timelines for geothermal development on federal KGRA land in California 
Table 4-4. Timebar estimates assumed in federal-land geothermal plant development timeline (Fig. 4-3) (times a re not cumulative)

\begin{tabular}{|c|c|c|}
\hline Activity $T$ imebar & $\begin{array}{l}\text { Estimated } \\
\text { Time } \\
\text { Requirement } \\
\text { (months) }\end{array}$ & Comments \\
\hline \multicolumn{3}{|c|}{ LAND ACQUISITION AND EXPLORATION } \\
\hline $\begin{array}{l}\text { File "Notice of Intent" and obtain } \\
\text { prospecting permit }\end{array}$ & 1 & $\begin{array}{l}\text { Preliminary exploration cannot begin until } \\
\text { either prospecting permit is obtained or lease } \\
\text { is obtained. }\end{array}$ \\
\hline Preliminary exploration & 3 & $\begin{array}{l}\text { More time could be required if data are not as } \\
\text { promising as expected. }\end{array}$ \\
\hline $\begin{array}{l}\text { Process leases and EIS; obtain } \\
\text { permit to drill }\end{array}$ & 24 & $\begin{array}{l}\text { Less time would be required }(9-12 \text { months) if } \\
\text { no EIS were required. }\end{array}$ \\
\hline $\begin{array}{l}\text { Other exploration and reservoir } \\
\text { assessment }\end{array}$ & 48 & $\begin{array}{l}\text { Assess extent of reservoir. Total time might } \\
\text { be less because the timeline endpoint was } \\
\text { based on when exploratory drilling is } \\
\text { completed. }\end{array}$ \\
\hline $\begin{array}{l}\text { Exploratory drilling and } \\
\text { reservoir evaluation }\end{array}$ & $24^{*}$ & $\begin{array}{l}\text { Assumes (1) requirement for discovery } \\
\text { (wildcat) well, seven stepout wells, three non- } \\
\text { producing wells, and flow tests of first four } \\
\text { wells for eight months and ( } 2 \text { ) drilling by one } \\
\text { rig with one well taking two months. }\end{array}$ \\
\hline Site selection & 2 & $\begin{array}{l}\text { Plant and well locations selected. Time } \\
\text { ranges from one to three months depending on } \\
\text { terrain. }\end{array}$ \\
\hline Feasibility study & 5 & Economic viability determined. \\
\hline Financial negotiations & 8 & $\begin{array}{l}\text { Negotiations between producer and user } \\
\text { (normally a utility). }\end{array}$ \\
\hline \multicolumn{3}{|c|}{ DEVELOPMENT AND PRODUCTION } \\
\hline Preliminary design & 6 & $\begin{array}{l}\text { Cycle design selected, long-lead hardware } \\
\text { ordered. }\end{array}$ \\
\hline Prepare MDP and EDS & 6 & Prepared by producer/utility \\
\hline Final design & 14 & $\begin{array}{l}\text { Detailed plant design. Other hardware and } \\
\text { equipment procurements initiated. }\end{array}$ \\
\hline $\begin{array}{l}\text { Certify plant and obtain } \\
\text { permits (if USFS land, EIS } \\
\text { would al so be processed) }\end{array}$ & 18 & $\begin{array}{l}\text { Represents large uncertainty due to absence } \\
\text { of precedent. }\end{array}$ \\
\hline $\begin{array}{l}\text { Development drilling and } \\
\text { piping }\end{array}$ & 26 & $\begin{array}{l}\text { Assumes that, if necessary, more than one } \\
\text { rig available to complete wells two months } \\
\text { before completing plant construction. }\end{array}$ \\
\hline $\begin{array}{l}\text { Construction and initial } \\
\text { operation }\end{array}$ & 27 & \\
\hline $\begin{array}{l}\text { r an established field, this } \\
\text { bably be adequate. }\end{array}$ & 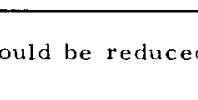 & ry wells would \\
\hline
\end{tabular}




\section{Nonelectric Applications}

A timeline estimated for geothermal development of a nonelectric application on federal land in California is presented in Fig. 4-3(b).

The actual extent of exploration and drilling will depend to a large extent on the particular application and the required number (and depth) of wells necessary to support such an application. For purposes of this discussion the application assumed was space heating a group of buildings requiring less than 10 relatively shallow wells. Environmental procedures requirements were assumed to be less than for the electric application (see Fig. 4-3(a)). A total time of one year was allotted for retrofitting and installation of equipment. Estimated total development time was determined to be about 5 years.

There are potential nonelectric applications which might not need exploration and resource assessment as extensive as that shown in Fig. 4-3(b). In this case, if it were also possible to accelerate the environmental approval cycle, it is conceivable that the timeline might be reduced to between 3 and $31 / 2$ years.

F EDERAL ADMINISTRATIVE PROCESSING TIME REQUIREMENTS

\section{Electric Application}

A detailed flow chart of the leasing and permitting/approving time requirements estimated for geothermal plant development on federal land in California leading to an electric application is shown in Fig. 4-4. The times shown are considered typical but will vary as a function of the particular area in which development is taking place.

The administrative requirements governing construction of a power plant for utilization of geothermal resources on federal land a re unclear at this time. In addition to permits and plant certification being required by the appropriate federal agency, similar approvals and permits might be required by the California Energy Resources Conservation and Development Commission 


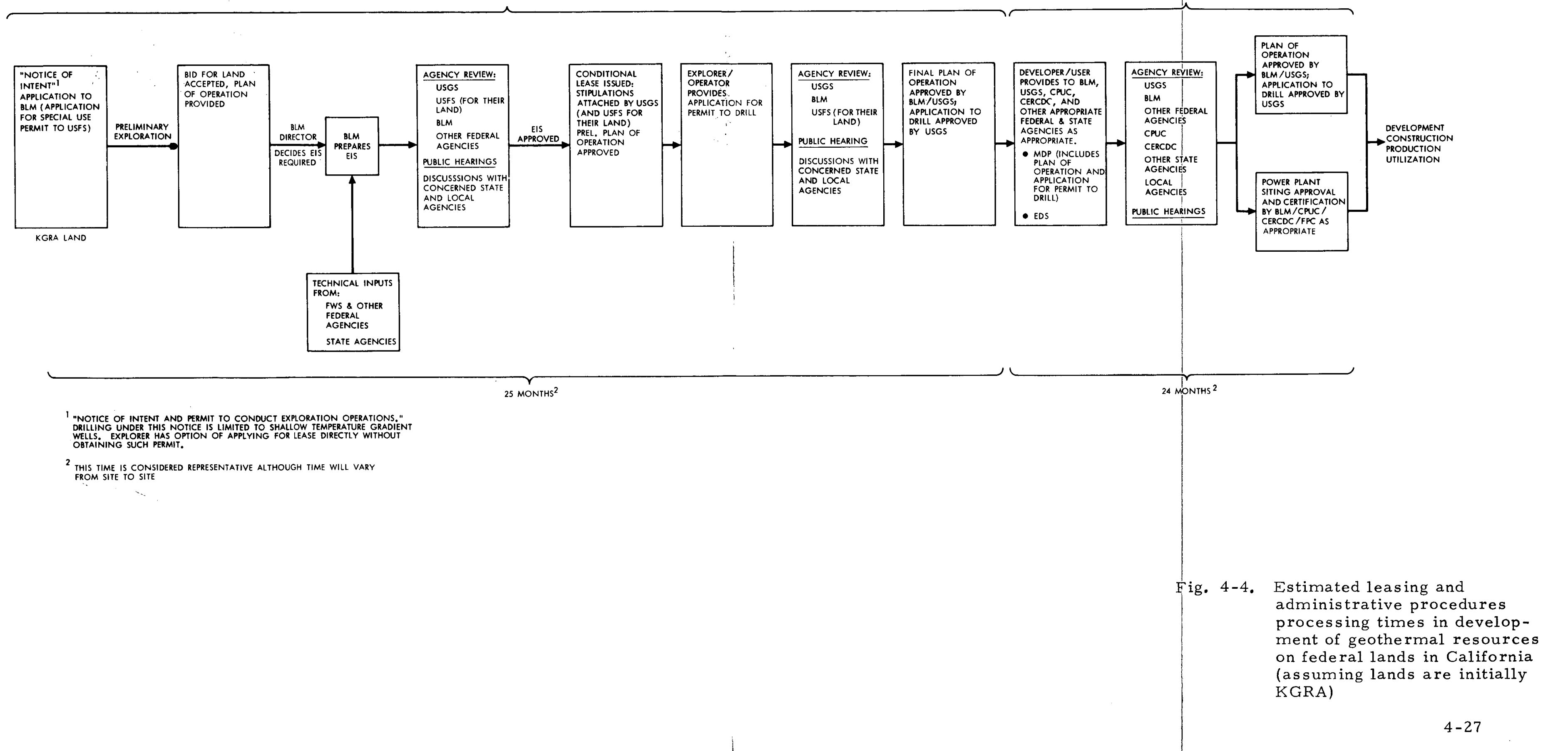



(CERCDC). The uncertainty is due to the fact that no plant has yet been constructed on federal land nor have the roles of the U.S. Geological Survey, the Bureau of Land Management, or the Federal Power Commission been specified in detail. Furthermore, CERCDC has not yet processed an NOI (Notice of Intention to File an Application for Certification) or an Application for Certification.

\section{Nonelectric Applications}

Total processing time for nonelectric applications would be expected to be less than that for the electric applications case, but the extent of reduction is difficult to estimate at this time. The time to acquire leases is assumed to be identical to that expected in the geothermal development for electric applications. However, reduced times are assumed for the activities during development. These requirements are not as extensive nor as complex as those for electric applications.

GEOTHERMAL DEVELOPMENT ON STATE AND PRIVATE LANDS IN CALIFORNIA

\section{STATE AND PRIVATE LAND LEASING PROCESS}

Acquisition of state lands may precede or follow exploratory drilling. In California, a prospecting permit issued by the State Lands Commission allows a developer to conduct exploration activities on state lands not designated as KGRAs without a lease or purchase. However, in the performance of exploration activities, a developer is subject to nearly the same administrative requirements whether he has committed to a lease or prospect rights. Prospecting without a lease may also be conducted on private lands as a result of negotiation between owner and operator. 
In California (as a result of the California Environmental Quality Act of 1970), geothermal exploration on state or private lands - irrespective of whether or not the lands are KGRAs - may not proceed without the preparation and evaluation of an Environmental Impact Report (EIR) of the proposed activities if a Negative Declaration is not appropriate under the circumstances. When the proposed project is to take place on private land, the county is the responsible agency for the preparation of the EIR. When the project is planned on state land, the State Lands Commission is responsible for preparing the EIR before approving a land lease for the proposed exploration activity. In either case, the EIR is reviewed by several state and local agencies, and public hearings are held before approval may be issued by the state for a drilling permit, and by the county for a land use permit. The permits are subjecl to regulations prescribed by the relevant agencies having an interest in the proposed activities.

DEVELOPMENT TIMELINES FOR STATE AND PRIVATE LAND

\section{Electric Applications}

The timelines for plant development on both state and private lands were determined to be essentially the same (see Fig. 4-5). * Estimated total time for an electric application is approximately 8 years. These estimates are similar to those for federal land shown in Fig. 4-3(a) except for the leasing and administrative processing time requirements.

Time for initial development would vary according to location and terrain. Similarly, second generation plant development on an established field would be expected to require significantly less time than that indicated in Fig. 4-5(a). For example, the minimum time requirement for the development of one $110 \mathrm{MW}$ geothermal power plant in The Geysers geothermal area has been estimated by the Geothermal Unit of the Division of Oil and Gas to be approximately $61 / 2$

\footnotetext{
*The sole exception to this assumption is that leasing negotiations as to private land might involve less time than that indicated for state land.
} 


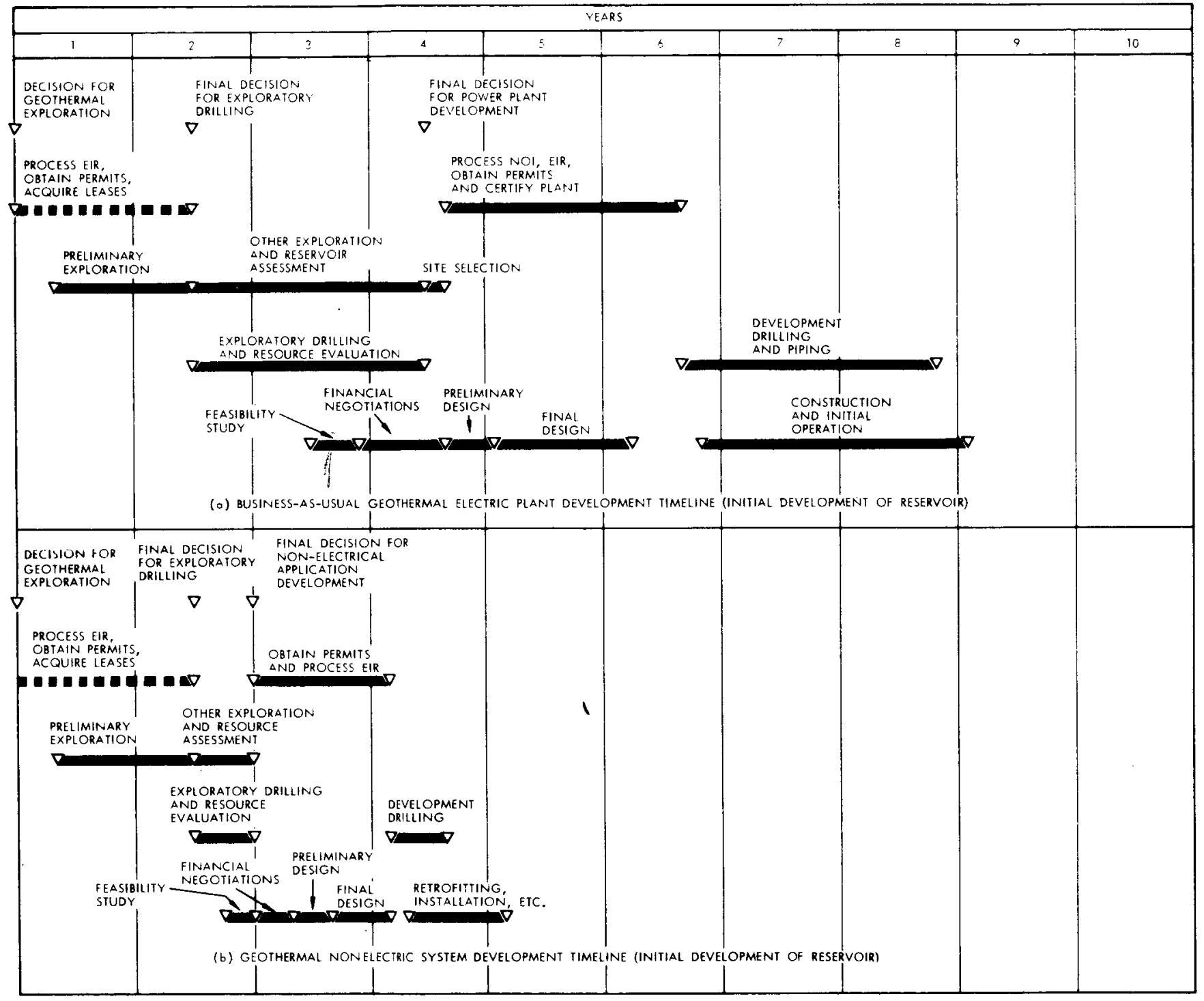

Fig. 4-5. Estimated timelines for geothermal development on state and private KGRA lands in California 
years from land acquisition to start of power generation. Only three wells were assumed to be necessary to confirm the resource (during Exploratory Drilling and Reservoir Evaluation). In addition, it was assumed that only 15 months (instead of 18 to 24 months) would be required for plant certification.

For state land, geothermal exploration is initiated by the explorer/ producer by applying to the State Lands Commission for prospecting permits. If a Negative Declaration is not deemed appropriate, but that an EIR is required, a minimum of 4 months for preparation, review, and approval is required before the permit is approved and preliminary exploration can be initiated. Often this time frame can exceed 4 months if there is controversy generated at the hearings.

On private land preliminary exploration can begin immediately after obtaining the owner's permission and consequently one could expect the Preliminary Exploration timebar in Fig. 4-5 to be initiated sooner. When it is determined that the areas under investigation look promising, the explorer/ producer would acquire the geothermal rights (leases) and county land permits before making more detailed explorations. At this same time the county would prepare (or have prepared) an EIR covering the proposed development program and hold the necessary hearings to determine whether or not to approve the exploration program (this assumes that a Negative Declaration is deemed inappropriate following the preliminary environmental assessment). At present, requirements of the various counties vary (see Section V), but for most counties the time necessary to process EIRs and acquire land use permits rarely exceeds 12 months after the land owner's permission is obtained. Consequently, total development times for the private land case could vary depending on the county in which the development is being accomplished, but in most cases would most likely be at least 5 months less than is required for a plant development on state land.

Since the lands in Fig. 4-5 a re state-or privately-owned, no federal agencies would be involved (except perhaps the Federal Power Commission if power were to be transmitted across state boundaries). The plant development phase is initiated by the utility's submitting a notice of intention to file an 
application for certification of the proposed site and facility. The approvals should be obtained within 18 months. However, the timeline reflects a 24 month time frame to account for delays caused by the utility's having to develop and/or obtain additional data to support the certification process.

\section{Nonelectric Applications}

A timeline estimate for nonelectric utilization applications on state and private lands in California is shown in Fig. 4-5(b). Assuming the same application as for the federal-land case (see page 4-22), the estimated total development time was determined to be 4 years and 2 months, approximately 1 year less than for the federal-land case. The major reason for this difference is that for the state/private land development, the time needed for the leasing and EIR processing activities was assumed to be less than for the federal land case.

\section{STATE AND LOCAL ADMINISTRATIVE PROCESSING TIME REQUIREMENTS}

Except for the leasing procedures, the various regulatory requirements for development of geothermal resources on both state and private lands are generally the same. Illustrated schematically in Fig. 4-6 a re the administrative requirements and ranges of times to accomplish these requirements for geothermal activities conducted on state or private lands in California. The two major phases of geothermal development are identified. Agencies requiring permits, as well as the processing times for approvals, are indicated. The times shown were obtained from an Office of Planning Research report ${ }^{*}$ and are considered typical of actual processing requirements for geothermal plant development in The Geysers a rea in Sonoma and Lake Counties.

As noted in the federal-land case (see page 4-26), process requirements would probably be considerably reduced for the case of nonelectric applications, but the extent of the reduction is not known at this time.

Kirkham, W. G., and Brown, S. T., State and Local Permit Study: An Analysis of Administrative Factors Affecting Geothermal Development at The Geysers. 


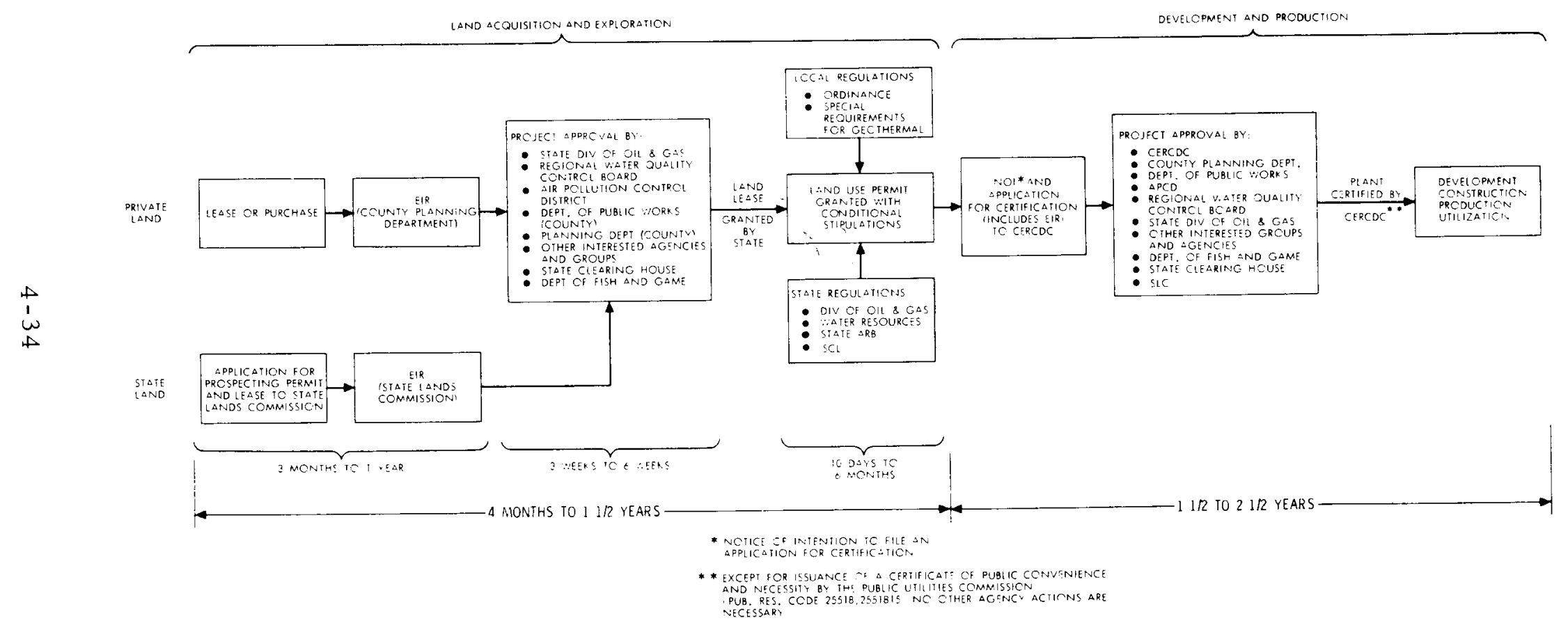

Fig. 4-6. Estimated leasing and administratre processing times in development of geothermal resources on state or private lands 


\section{SECTION V}

\section{REGIONA L DEVE LOPMENT STATUS}

The preceding sections have given definition to California's geothermal resource base, the current plans for its utilization, and the process involved in its development. This section presents the status of geothermal energy development activities in the five resource regions of the state. It includes first a comparative summary of the development status of the five regions and then a more detailed discussion of each of the regions, the KGRAs, the county perspectives on geothermal energy development, and a presentation of current development activities.

\section{SUMMARY - DEVELOPMENT STATUS}

Current geothermal energy utilization plans in the state, as described in Section III, are directed at the development of those resources capable of supporting electric power production; i.e., the high temperature hydrothermal systems. There are seven basic steps leading to the production of electrical power from a geothermal reservoir. The se steps, as described in Section IV, are:

1. Preliminary exploration (or reconnaissance).

2. Land acquisition (leasing).

3. Exploratory drilling.

4. Reservoir evaluation.

5. Preliminary plant design (including, if necessary, test loop or pilot plant operations to evaluate conversion cycles).

6. Plant design and construction and field development.

7. Plant operations.

The first four steps are devoted to locating and proving the existence of commercially viable reservoirs. The final steps lead to the development and operation of the facility for commercial power production. Table 5-1 lists the present 23 KGRAs in the state, by region, and shows the stage (or step) of 
Table 5-1. KGRA development status

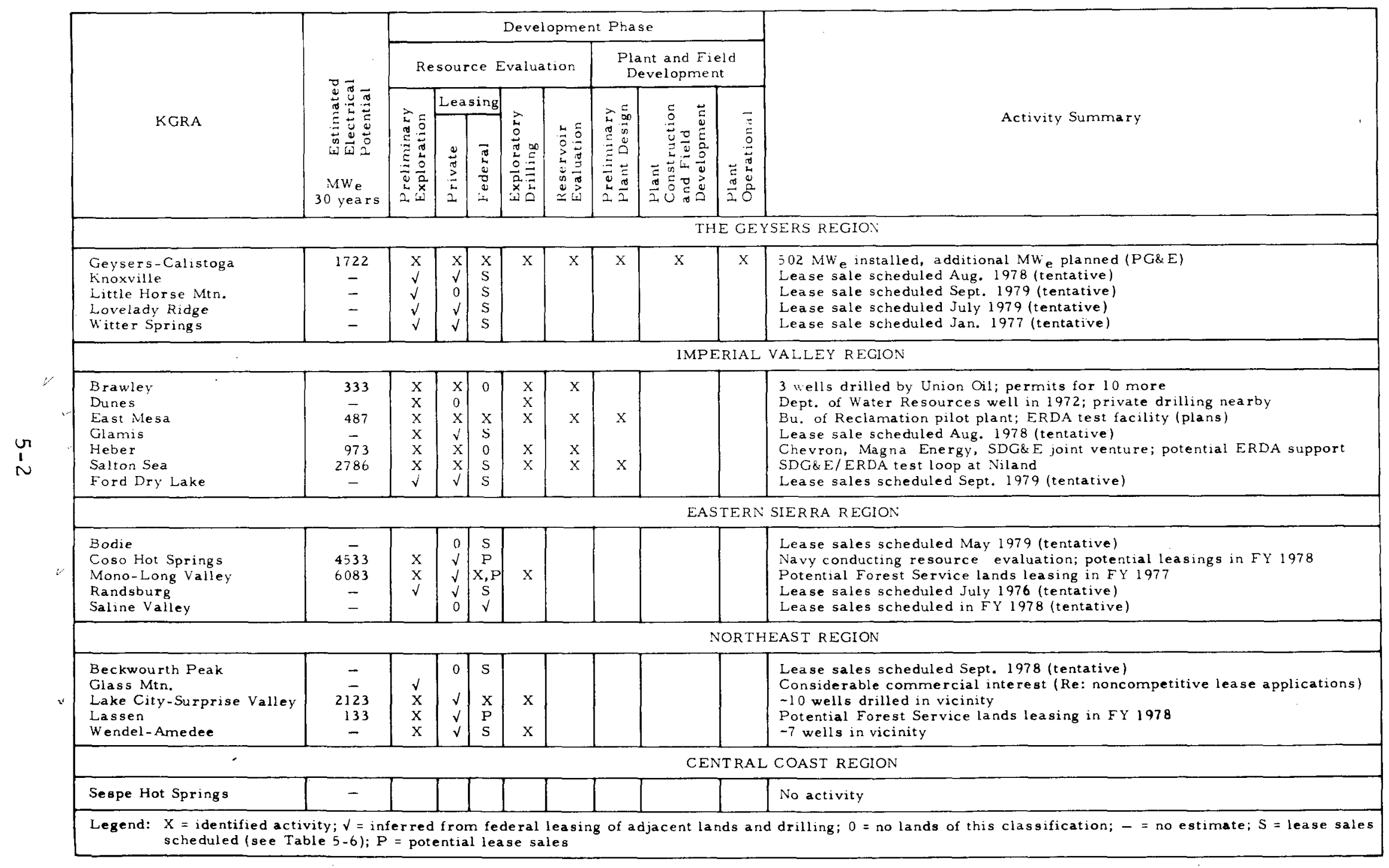


Table 5-2. Summary of drilling operations, by region (based on files of the Division of Oil and Gas)

\begin{tabular}{|l|c|c|c|c|c|c|c|}
\hline & \multirow{2}{*}{$\begin{array}{c}\text { Total } \\
\text { Rells, } \\
\text { Pre-1971 }\end{array}$} & \multicolumn{7}{|c|}{ New Wells } \\
\cline { 5 - 8 } & & 1971 & 1972 & 1973 & 1974 & 1975 & $\begin{array}{c}\text { Total, } \\
1971-75\end{array}$ \\
\hline The Geysers & 99 & 12 & 17 & 19 & 23 & 23 & 94 \\
Imperial Valley & 28 & 0 & 12 & 5 & 7 & 9 & 33 \\
Eastern Sierra & 11 & 2 & 0 & 0 & 0 & 0 & 2 \\
Northeast & 13 & 0 & 1 & 5 & 2 & 0 & 8 \\
Central Coast & 0 & 0 & 0 & 0 & 0 & 0 & 0 \\
\hline Totals & 151 & 14 & 30 & 29 & 32 & 32 & 137 \\
\hline
\end{tabular}

development of each. The full development cycle has been completed only at The Geysers-Calistoga KGRA where the Pacific Gas and Electric Company has $502 \mathrm{MW}$ of generating capability in operation and plans for an additional $1396 \mathrm{MW}_{\mathrm{e}}$ by 1985. The Imperial Valley Region is the next most advanced: test loop operations are under way at Niland in the Salton Sea KGRA and at the East Mesa KGRA, where the Bureau of Reclamation has a desalination pilot plant in operation. Two other sites in the Imperial Valley, Brawley and Heber, are in the reservoir evaluation stage. The development of the other regions and KGRAs in the state lags noticeably. Table 5-2 summarizes the number of geothermal wells drilled in the state, by region, over the past 5 years. Of the 135 wells reported 94 (70 percent) were in The Geysers Region and 31 (23 percent) in the Imperial Valley Region. Only two wells have been drilled recently in the Eastern Sierra Region, by the USGS in the Mono-Long Valley KGRA. Most of the wells drilled in the Northeast Region have been at Lake City-Surprise Valley and Wendel-Amedee areas. No wells have been drilled in the Central Coast Region. The companies associated with the drilling operations in the five regions are listed in Table 5-3. 
Table 5-3. Active operators, 1971-75

(based on drilling operations and

permit applications)

\begin{tabular}{|c|c|}
\hline Region & Operator \\
\hline The Geysers & $\begin{array}{l}\text { Burmah Oil and Gas Co. } \\
\text { Geothermal Kinetics Systems Corp. } \\
\text { McCulloch Oil Corp. } \\
\text { Thermal Power Co. } \\
\text { Union Oil Company of California } \\
\text { Pacific Gas and Electric Co. } \\
\text { Getty Oil Co. } \\
\text { Magma Energy, Inc. } \\
\text { Sulphur Bank Geothermal Power Co. } \\
\text { Shell Oil Co. } \\
\text { Sun Oil Co. } \\
\text { Cordero Mining Co. } \\
\text { Pacific Energy Corp. } \\
\text { Signal Oil and Gas Co. } \\
\text { Geothermal Resources International } \\
\text { E. B. Towne }\end{array}$ \\
\hline Imperial Valley & $\begin{array}{l}\text { Union Oil Company of California } \\
\text { Republic Geothermal, Inc. } \\
\text { Magma Energy, Inc. } \\
\text { U. S. Bureau of Reclamation } \\
\text { Chevron Oil Co. } \\
\text { New Albion Resources Co. } \\
\text { State Department of Water Resources } \\
\text { Q. B. International } \\
\text { Imperial Magma } \\
\text { Magma Power Co. } \\
\text { San Diego Gas and Electric Co. }\end{array}$ \\
\hline Northeast & $\begin{array}{l}\text { Magma Power Co. } \\
\text { American Thermal Resources, Inc. } \\
\text { Gulf Oil Corp. } \\
\text { Kelly Hot Springs, Ltd. } \\
\text { Magma Energy, Inc. } \\
\text { Phillips Petroleum Co. }\end{array}$ \\
\hline Eastern Sierra & $\begin{array}{l}\text { Geothermal Resources International } \\
\text { Getty Oil Co. } \\
\text { U.S. Navy } \\
\text { U.S. Geological Survey }\end{array}$ \\
\hline
\end{tabular}


SUMMARY - LEASING STATUS

Until the passage of the Geothermal Steam Act of 1970 only private and state lands were available for commercial geothermal energy development. Federal lands made eligible for geothermal leasing under the Act include certain lands administered by the Secretary of the Interior; lands administered by the Department of Agriculture through the Forest Service; and lands for which title has been conveyed by the United States subject to reservation to the United States of geothermal resources. Table 5-4 shows the land classifications of the current KGRAs. Of the 1, 409,641 acres included within the 23 KGRAs in the state, 55 percent are federal lands subject to the Act. However, 80 percent of the 729, 000 acres of KGRA lands of the Eastern Sierra, Northeast, and Central Coast Regions are federal lands. Only 25 percent and 35 percent of The Geysers and Imperial Valley Region KGRAs are federal lands. Practically all of the development that has occurred to date has been on state and private lands. (The exception is the Bureau of Reclamation operation at East Mesa.) The unavailability of federal lands, until recently, has been a decisive factor limiting the development of the resources of the Eastern Sierra and Northeast Regions.

In January of 1974 the federal government opened the federal lands subject to the Act for leasing. Those lands within KGRAs a re subject to competitive lease sales. Table 5-5 shows the results of the competitive lease sales in the four KGRAs in which land has been offered through January 1976. Of the 87,260 acres offered, bids were received and accepted (after two reoffers) on 36,592 acres. Figure 5-1 shows the current status of the competitive leasing program by region. The Bureau of Land Management is stepping up its program of lease sales on the lands under its direct jurisdiction in accordance with the schedule given in Table 5-6. In addition, several areas under the jurisdiction of other agencies may possibly be available in the next several years. These could include Forest Service lands in the Mono-Long Valley and Lassen KGRAs and the United States Navy lands in the Coso Hot Springs KGRA.

Federal lands subject to the Act but not in KGRAs are open to noncompetitive leasing. Over 900 non-competitive lease applications have been filed on lands within the state. Many have since been withdrawn or rejected. 
Table 5-4. KGRA land classification (Jan. 31, 1976)

\begin{tabular}{|c|c|c|c|c|c|}
\hline \multirow[b]{2}{*}{ KGRA } & \multirow[b]{2}{*}{$\begin{array}{l}\text { Total KGRA Area } \\
\text { (acres) }\end{array}$} & \multirow[b]{2}{*}{$\begin{array}{l}\text { Private, } \\
\text { State and Other }\end{array}$} & \multicolumn{3}{|c|}{$\begin{array}{c}\text { Federal Lands } \\
\text { (Subject to the Act) }\end{array}$} \\
\hline & & & $B L M^{(1)}$ & $\begin{array}{l}\text { Forest } \\
\text { Service }\end{array}$ & Other \\
\hline \multicolumn{6}{|c|}{ THE GEYSERS REGION } \\
\hline $\begin{array}{l}\text { Geysers-Calistoga } \\
\text { Knoxville } \\
\text { Little Horse Mtn. } \\
\text { Lovelady Ridge } \\
\text { Witter Springs }\end{array}$ & $\begin{array}{r}37,687 \\
14,702 \\
1,188 \\
6,887 \\
18,152 \\
\end{array}$ & $\begin{array}{r}296,268 \\
5,107 \\
0 \\
1,239 \\
13,663 \\
\end{array}$ & $\begin{array}{r}76,748 \\
9,595 \\
0 \\
3,090 \\
4,489 \\
\end{array}$ & $\begin{array}{l}5,671 \\
0 \\
1,188 \\
2,558 \\
0 \\
\end{array}$ & $\begin{array}{l}0 \\
0 \\
0 \\
0 \\
0 \\
0\end{array}$ \\
\hline & 419,616 & 316,277 & 93,922 & 9,417 & 0 \\
\hline \multicolumn{6}{|c|}{ IMPERIAL VALLEY REGION } \\
\hline $\begin{array}{l}\text { Brawley } \\
\text { Dunes } \\
\text { East Mesa } \\
\text { Glamis } \\
\text { Heber } \\
\text { Salton Sea } \\
\text { Ford Dry Lake }\end{array}$ & $\begin{array}{r}28,885 \\
7,680 \\
37,565 \\
25,505 \\
58,568 \\
95,014 \\
7,687 \\
\end{array}$ & $\begin{array}{r}28,885 \\
0 \\
4,840 \\
2,080 \\
58,568 \\
76,370 \\
520 \\
\end{array}$ & $\begin{array}{l}0 \\
0 \\
0 \\
0 \\
0 \\
0 \\
7,167 \\
\end{array}$ & $\begin{array}{l}0 \\
0 \\
0 \\
0 \\
0 \\
0 \\
0 \\
\end{array}$ & $\begin{array}{c}0 \\
7,680^{(2)} \\
32,725^{(2)} \\
23,425^{(2)} \\
0 \\
18,644^{(2)} \\
0 \\
\end{array}$ \\
\hline Subtotal & 260,904 & 171,263 & 7,167 & 0 & 82,474 \\
\hline \multicolumn{6}{|c|}{ EASTERN SIERRA REGION } \\
\hline $\begin{array}{l}\text { Bodie } \\
\text { Coso Hot Springs } \\
\text { Mono-Long Valley } \\
\text { Randsburg } \\
\text { Saline Valley }\end{array}$ & $\begin{array}{r}640 \\
51,760 \\
455,256 \\
12,886 \\
3,200 \\
\end{array}$ & $\begin{array}{r}0 \\
8,430 \\
63,160 \\
1,233 \\
0 \\
\end{array}$ & $\begin{array}{r}640 \\
16,690 \\
103,690 \\
11,653 \\
3,200 \\
\end{array}$ & $\begin{array}{r}0 \\
0 \\
288,406 \\
0 \\
0 \\
\end{array}$ & $\begin{array}{c}0 \\
26,640^{(3)} \\
0 \\
0 \\
0 \\
\end{array}$ \\
\hline Subtotal & 523,742 & 72,823 & 135,873 & 288,406 & 26,640 \\
\hline \multicolumn{6}{|c|}{ NORTHEAST REGION } \\
\hline $\begin{array}{l}\text { Beckwourth Peak } \\
\text { Glass Mtn } \\
\text { Lake City-Surprise Valley } \\
\text { Lassen } \\
\text { Wendel-Amedee }\end{array}$ & $\begin{array}{r}2,558 \\
33,502 \\
66,251 \\
78,642 \\
17,292 \\
\end{array}$ & $\begin{array}{r}0 \\
32,301 \\
24,002 \\
13,312 \\
\end{array}$ & $\begin{array}{r}2,558 \\
0 \\
31,972 \\
0 \\
3,980 \\
\end{array}$ & $\begin{array}{r}0 \\
32,601 \\
1,880 \\
54,640 \\
0 \\
\end{array}$ & $\begin{array}{l}0 \\
0 \\
0 \\
0 \\
0 \\
\end{array}$ \\
\hline Subtotal & 198,245 & 70,614 & 38,510 & 89,121 & 0 \\
\hline \multicolumn{6}{|c|}{ CENTRAL COAST REGION } \\
\hline Sespe Hot Springs & 7,134 & 454 & 0 & 6.680 & 0 \\
\hline Totals & $1,409,641$ & $\begin{array}{l}631,431 \\
\left(44.8 r_{0}\right)\end{array}$ & $\begin{array}{l}275,472 \\
(19.0 \%\end{array}$ & $\begin{array}{l}393,624 \\
\left(27.9^{\circ}, 0\right)\end{array}$ & $\begin{array}{r}109,114 \\
(7.7 \%, 0)\end{array}$ \\
\hline
\end{tabular}


Table 5-5. Competitive geothermal lease sale summary (January 31, 1976)

\begin{tabular}{|c|c|c|c|c|c|c|c|c|c|c|c|c|c|}
\hline \multirow{2}{*}{$\begin{array}{c}\text { Lease Sale Date } \\
\text { and } K \subset R A\end{array}$} & \multicolumn{2}{|c|}{ Linats Oflered } & \multicolumn{2}{|c|}{ Cints isid on } & \multicolumn{2}{|c|}{ Winats Accepted } & \multirow{2}{*}{$\begin{array}{l}\text { Leases } \\
\text { 1ssued } \\
\text { (No.1 }\end{array}$} & \multirow{2}{*}{$\begin{array}{l}\text { Acreage } \\
\text { Under } \\
\text { Lease }\end{array}$} & \multirow{2}{*}{$\begin{array}{l}\text { Toul of } \\
\text { Accepted } \\
\text { Mrgi: Bidis }\end{array}$} & \multirow{2}{*}{$\begin{array}{l}\text { Highest } \\
\text { Per Acre } \\
\text { Bid }\end{array}$} & \multirow{2}{*}{$\begin{array}{l}\text { Average } \\
\text { Frice Per } \\
\text { Acre }\end{array}$} & \multirow[b]{2}{*}{ Hogh Eidder $(s)$} & \multirow{2}{*}{$\begin{array}{l}\text { Yo. of } \\
\text { Eids } \\
\text { Received }\end{array}$} \\
\hline & No. & Acreage & No. & Acreage & $\therefore$. & Acreage & & & & & & & \\
\hline $\begin{array}{l}\text { Jung, } 22,1974 \\
\text { The cicysers }\end{array}$ & 12 & $8,7=5$ & 12 & 8,755 & 10 & 7,969 & 10 & 7.909 & $5 j, 045,247$ & $\$ 1.307 .52$ & $\$ 033.10$ & $\begin{array}{l}\text { Shell Oil Co. } \\
\text { Thermogenics, } \\
\text { Inc. } \\
\text { Union Oal Co. } \\
\text { Signal Oil Co. } \\
\text { Occidental Pet. }\end{array}$ & 42 \\
\hline $\begin{array}{l}\operatorname{Jand}, 22, \quad 1974 \\
\text { Last Mlesa }\end{array}$ & 14 & 30,169 & 5 & 9,210 & 5 & 9,210 & 5 & 9,210 & 053,133 & 109.79 & 70.91 & $\begin{array}{l}\text { Magma Power Co. } \\
\text { Republic } \\
\text { Geothermal, } \\
\text { Inc. }\end{array}$ & 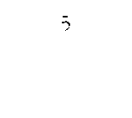 \\
\hline $\begin{array}{l}\text { Jall. } 22,1974 \\
\text { Mono-Long } \\
\text { valley }\end{array}$ & i & 13,715 & 3 & 5.483 & 3 & 5,483 & 3 & 5.483 & 032,818 & 290.90 & 115.41 & $\begin{array}{l}\text { Chevron Oil Co. } \\
\text { Getty Oil Co. } \\
\text { Republic } \\
\text { Geothermal. } \\
\text { Inc. }\end{array}$ & 10 \\
\hline $\begin{array}{l}\text { May } 29,1974 \\
\text { The Gelsers } \\
\text { (Reofiered) }\end{array}$ & 2 & 780 & 2 & 786 & 2 & 780 & 2 & 780 & $2,275,000$ & $3,282.74$ & $2,894.40$ & $\begin{array}{l}\text { Natomas Co. } \\
\text { Occidental Pet. }\end{array}$ & 8 \\
\hline 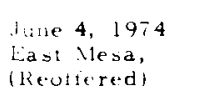 & 9 & 20,959 & 1 & 2,560 & 1 & 2,560 & 1 & 2,360 & 8,371 & 3.27 & 3.27 & $\begin{array}{l}\text { Republic } \\
\text { Geothermal, } \\
\text { Inc. }\end{array}$ & 1 \\
\hline 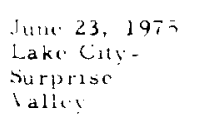 & 10 & 34,591 & ; & 10,584 & 5 & 10,584 & 0 & 0 & 134,533 & 21.53 & 12.71 & $\begin{array}{l}\text { Getty Oil Co. } \\
\text { Dow Chemical Co. } \\
\text { Southern Union } \\
\text { Production Co. }\end{array}$ & 6 \\
\hline
\end{tabular}




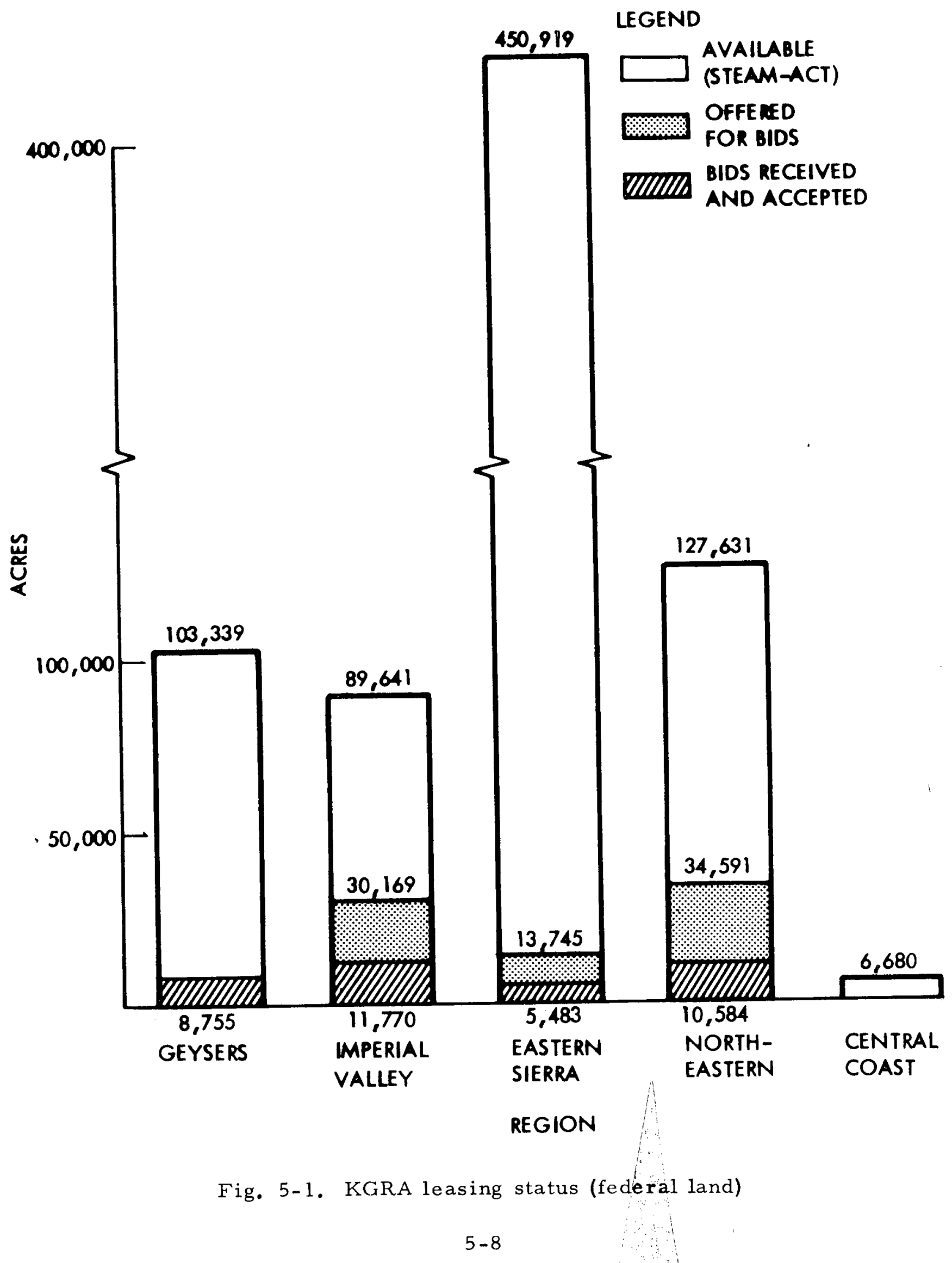


Table 5-6. Tentative KGRA (competitive) lease sale schedule, as of March 1976 (BLM-administered lands)

FY 1976

July $1976 \ldots \ldots \ldots$ Randsburg

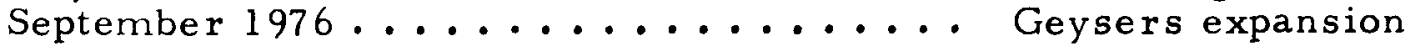

FY 1977

January $1977 \ldots \ldots \ldots$ Wendel - A medee

January $1977 \ldots \ldots \ldots$ Witter Springs

September 1977................... Indian Valley (Geysers)

FY 1978

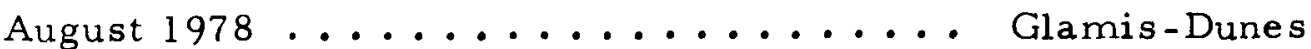

August $1978 \ldots \ldots \ldots$ Knoxville

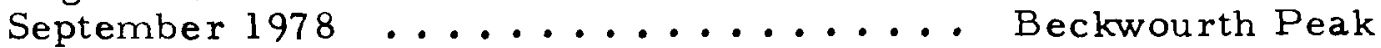

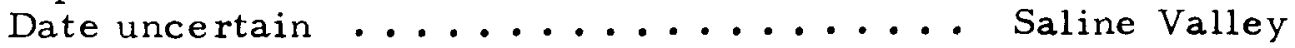

FY 1979

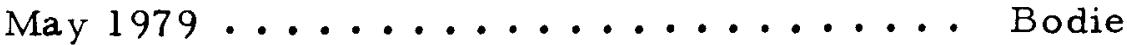

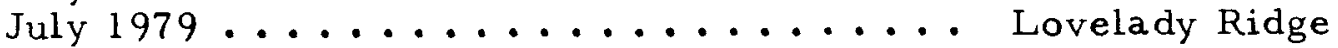

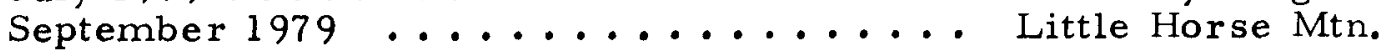

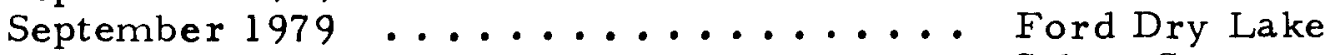

Date uncertain .................................... Sa

Three noncompetitive leases have been awarded to date on 3,191 acres in the Lake City area; 458 are awaiting action. The Bureau of Land Management established a tentative schedule for noncompetitive leases within the state as given in Table 5-7. It is paced by the preparation of the necessary EARs for each of the areas listed.

Approximately 10 percent of the land within fede rally designated KGRAs is land which is either owned outright by the state or is land for which the state has retained mineral rights. In The Geysers-Calistoga KGRA two such areas have producing wells and are designated as state GRAs. The two leases in these areas are producing nearly $\$ 90,000$ per month royalty income. At present, owing to litigation concerning whether the geothermal resource 
Table 5-7. Tentative noncompetitive leasing schedule (BLM-administered lands)

\begin{tabular}{|c|c|}
\hline Area & Region \\
\hline \multicolumn{2}{|c|}{ FY 1976} \\
\hline Searles Lake & Eastern Sierra \\
\hline Alturas & Northeast \\
\hline Cow Mtn. & Geysers \\
\hline Middle Mtn. & Geysers \\
\hline Geysers Extension & Geysers \\
\hline Tule Elk & Geysers \\
\hline Randsburg & Eastern Sierra \\
\hline Witter Springs & Geysers \\
\hline \multicolumn{2}{|c|}{ FY 1977} \\
\hline Owens Lake & Eastern Sierra \\
\hline Tecopa & Eastern Sierra \\
\hline Wendel-Amedee & Northeast \\
\hline Indian Valley & Geysers \\
\hline Yuha & Imperial \\
\hline Anza & Imperial \\
\hline N. Salton Sea & Imperial \\
\hline \multicolumn{2}{|c|}{ FY 1978} \\
\hline Saline Valley & Eastern Sierra \\
\hline Beckwourth & Northeast \\
\hline Hayden Hill & Northeast \\
\hline Timbered Crater & Northeast \\
\hline Knoxville & Geysers \\
\hline Glamis & Imperial \\
\hline Dunes & Imperial \\
\hline East Mesa & Imperial \\
\hline
\end{tabular}


falls within the definition of mineral rights retained by the state, the royalties are being held in trust. Over $\$ 2$ million dollars had accrued in the trust by the end of 1975.

State lands are open to potential developers upon payment of a fee and receipt of a prospecting permit. Subsequently, if the prospector discovers geothermal resources in commercial quantities and the environmental impact report is favorable, he has preferential right to a lease from the State Lands Commission.

By November of 1975 three geothermal leases had been issued. Two in The Geysers and one at the Salton Sea. An additional lease was authorized in The Geysers-Calistoga area late in December 1975. State lands lease and prospecting permits issued prior to December 1975 are summarized in Table 5-8. A tabulation of geothermal wells drilled on state permits and leases appears in Table $5-9$.

SUMMARY - COUNTY DEVELOPMENT REQUIREMENTS AND PERSPECTIVES

California counties have been delegated substantial authority for making land use decisions. There are few other states which have given so much autonomy to county level government and have had that responsibility so significantly employed. The county attitudes toward the development of geothe rmal resources in their jurisdiction strongly influence that development. A composite of the views, and the energy regulations, of 14 counties investigated in the preparation of this report are highlighted here. The counties include Imperial, Inyo, Mono, Plumas, Lassen, Modoc, Siskiyou, Shasta, Tehema, Colusa, Lake, Napa, Mendocino, and Sonoma.

There are strong feelings at the county level that citizens should be duly consulted in matters affecting local land use and that the local governments are the most representative and knowledgeable of local sentiment. With perhaps the exception of Sonoma County, the counties have deep-abiding reservations about energy development within their areas. They are unmoved by the invoking of national energy needs as a valid reason for the development of resources in their "backyard", particularly when such development is for the benefit of outside regions or users. Instead, the interest and motivation, 
Table 5-8. State lands within potential geothermal areas - approximate acreage (source: State Lands Commission, Dec. 15, 1975)

\begin{tabular}{|c|c|c|c|c|c|c|}
\hline County & $\begin{array}{l}\text { Under Lease } \\
\text { (Xo.) }\end{array}$ & $\begin{array}{l}\text { Under Prospecting } \\
\text { Permit (Xo.) }\end{array}$ & $\begin{array}{c}\text { Under Application } \\
(\text { (No.) }\end{array}$ & State Land & $\begin{array}{l}\text { State Minerals } \\
\text { Reserved }\end{array}$ & County Total \\
\hline Imperial & $535(1)$ & $3,893(2)$ & $3,770(8)$ & 23,787 & 8,417 & 32,204 \\
\hline Inyo & 0 & $14,738(3)$ & $765(1)$ & 80,350 & 3,000 & $83,350^{a}$ \\
\hline Lake & $712(1)$ & 0 & $15,947(23)$ & 40,237 & 9,981 & $50,218^{b}$ \\
\hline Lassen & 0 & 0 & 0 & 95,390 & 4,873 & $100,263^{c}$ \\
\hline Mendocino & 0 & 0 & $160(2)$ & 3,995 & 1,713 & 5,708 \\
\hline Modoc & 0 & $17,955(4)$ & 0 & 155,880 & 2,456 & $158,336^{d}$ \\
\hline Mono & 0 & 0 & $3,920(2)$ & 57,886 & 2,880 & $60,766^{e}$ \\
\hline Napa & 0 & 0 & $2,480(2)$ & 400 & 3,379 & 3,779 \\
\hline Plumes & 0 & 0 & 0 & 1,640 & 0 & 1,040 \\
\hline San Bernardino & 0 & 0 & $1,426(3)$ & 995 & 960 & 1,955 \\
\hline Sonoma & $3,276(1)$ & 0 & $2,062(11)$ & 6,658 & 40 & 0.698 \\
\hline Totals & $4,523(3)$ & $36,586(9)$ & $30,530(52)$ & 467,218 & 37,699 & 504,917 \\
\hline \multicolumn{7}{|c|}{$(92.44,0)$} \\
\hline $\begin{array}{l}\text { a. Includes Owen } \\
\text { b. Includes Clear } \\
\text { c. Includes Hone } \\
\text { d. Includes Uppe } \\
\text { e. Includes Mono }\end{array}$ & $\begin{array}{l}\text { ke }(71,310 \text { acr } \\
\text { ke }(39,607 \text { acre } \\
\text { ke }(57,490 \text { acre } \\
\text { liddle and Lowe } \\
\text { e }(51,960 \text { acro }\end{array}$ & Ikali Lake, Goose I & and Wright Lake & 2,680 acres) & & \\
\hline
\end{tabular}


Table 5-9. Geothermal wells summary, as of Dec. 15, 1975

(permits and leases) - source: State Lands Commission

\begin{tabular}{|c|c|c|c|c|c|c|c|c|}
\hline P. R. C. & Area & Producing & S. I. & Idle & Suspended & Injection & Abandoned & $\begin{array}{c}\text { Total } \\
\text { Drilled }\end{array}$ \\
\hline $\begin{array}{l}\text { Permit } \\
4397.1\end{array}$ & $\begin{array}{l}\text { Mono } \\
\text { Lake }\end{array}$ & 0 & 0 & 0 & 0 & 0 & 1 & 1 \\
\hline $\begin{array}{l}\text { Permit } \\
4572.1\end{array}$ & $\begin{array}{l}\text { Mono } \\
\text { Lake }\end{array}$ & 0 & 0 & 0 & 0 & 0 & 1 & 1 \\
\hline $\begin{array}{l}\text { Lease } \\
4976.0\end{array}$ & $\begin{array}{l}\text { Salton } \\
\text { Sea }\end{array}$ & 0 & 1 & 0 & 0 & 0 & 0 & 1 \\
\hline $\begin{array}{l}\text { Lease } \\
4596.1\end{array}$ & $\begin{array}{l}\text { The } \\
\text { Geysers }\end{array}$ & 33 & 0 & 3 & 0 & 2 & 1 & 39 \\
\hline $\begin{array}{l}\text { Lease } \\
4597.1\end{array}$ & $\begin{array}{l}\text { The } \\
\text { Geysers }\end{array}$ & 15 & 1 & 0 & 3 & 1 & 0 & 20 \\
\hline & Totals & 48 & 2 & 3 & 3 & 3 & 3 & 62 \\
\hline
\end{tabular}

P.R.C. = Public Resources Code; S.I. = Shut In

when it exists, for developing indigenous resources comes from the desire for jobs to keep young people at home, jobs to enhance sagging economies - e.g., where the lumber industry was seen as being on a steady decline, and to assure local energy supplies with a modest hope for reduced energy costs. Even with the se factors as motivation, other considerations weigh heavily upon local decision-makers and their constituents. Rural counties often want to retain a quality of life which is no different from the present. Few of the counties visited would qualify as favoring growth-oriented policies. In those localities where the re exists a fairly even mix of retirement and working populations, internal disagreements on growth policies are very much in evidence. All counties are extremely concerned that energy development activities be compatible with existing enterprises. Some counties show great antagonism to the introduction of industrie $s$ different than those already established. Nonelectric enterprises are favorably viewed, in these instances, only when the heat would be used for members of established industries. Those counties having little to no experience with geothermal energy showed ranges of interest from immensely interested to an interest predicated upon justification of this resources development. If the questions of environmental quality and 
socioeconomic welfare are met, it can be expected that geothermal energy development will be able to proceed generally without great obstacles. Given these preconditions, Fig. 5-2 depicts the attitudes of the counties toward geothe rmal energy development.

The question of jurisdictional responsibility between county and federal government was one of the critical issues raised in our investigation. Many counties, particularly ones with large landholdings under federal management, are concerned that activities conducted on those lands be consistent with local regulations governing land use. Several counties a re claiming that operators on fede rally owned lands must obtain the appropriate permits from the local government. The feelings are strong enough to suggest the possibility of a legal suit, if necessary, to resolve jurisdictional disputes in the future.

\section{SUMMARY - PROCEDURAL REQUIREMENTS AND ENERGY REGULATION}

All of the KGRA counties require conditional use permits for geothermal energy exploration and development. Most require it for shallow temperature gradient testing. Imperial and Mono Counties have separate permits for "Exploratory Wells" and "Production Projects". Costs for use permit applications range from $\$ 10$ to $\$ 75$, exclusive of fees for performing an environmental assessment or preparing an EIR. The final decision on a use permit consumes from 2 weeks to 10 months depending upon the need for an EIR and the sophistication of county procedures. Table 5-10 shows the times associated with the use permit process in the various counties. The determination of whether to do an EIR, and the preparation and review of EIRs are variable entities which also, in part, seem to vary with the size of decisionmaking constituencies and their sophistication about specific issues. The lesser populated counties usually have had relatively little trouble in performing quick environmental assessments. When they were required to process EIRs, they did so in less time than counties with larger populations and major is sues associated with the EIR preparation.

Preparation of EIRs is usually done by a county department, a consultant to the county, or a consultant to the applicant, depending on the county. The costs vary from $\$ 15$ to $\$ 100$ for an application for an environmental assessment; for EIR preparation the cost ranges from $\$ 300$ to $\$ 50,000$, or more. 


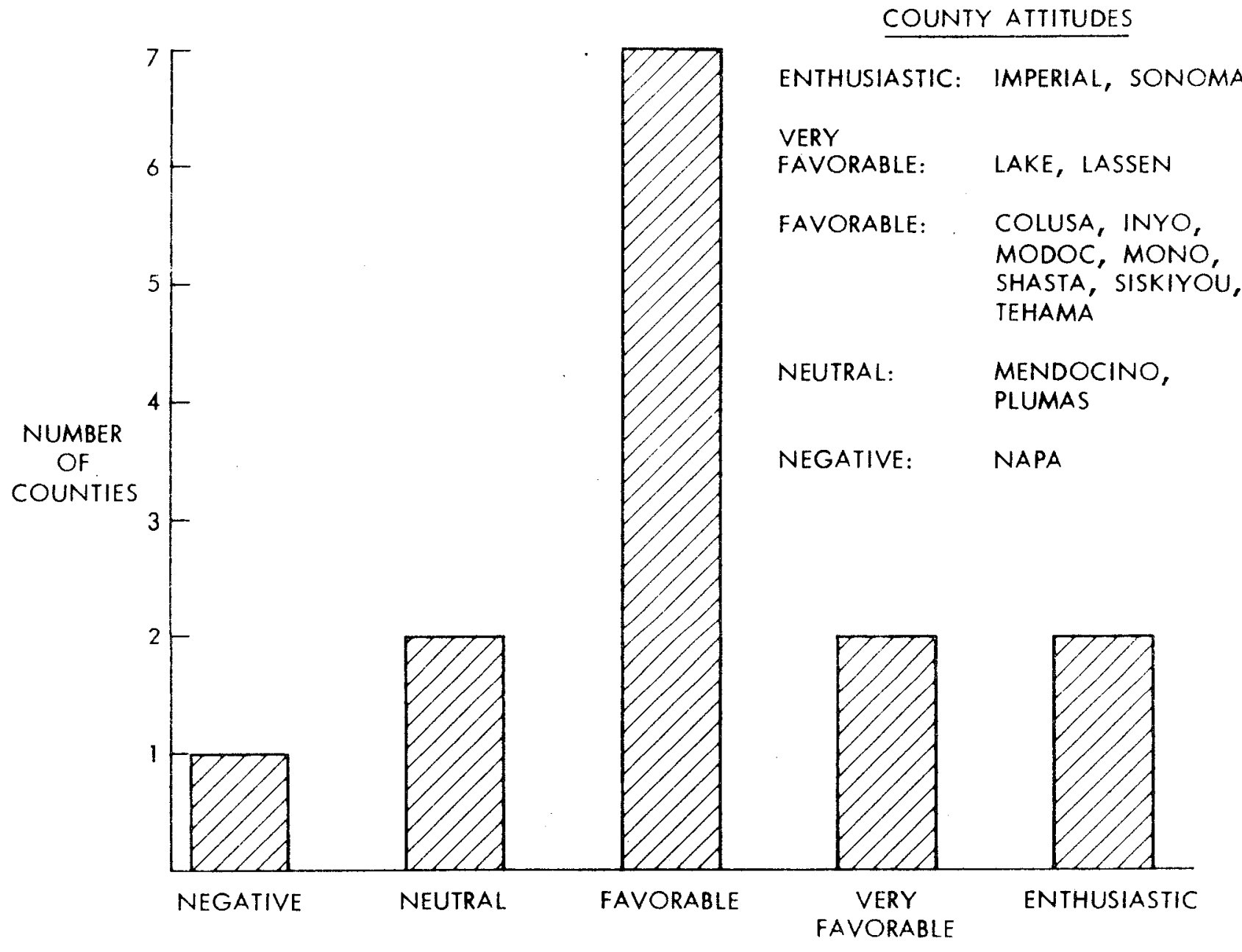

Fig. 5-2. Composite graph of attitudes toward geothermal energy development 
Table 5-10. Use permit/EIR times for final decisions

\begin{tabular}{|c|c|c|c|}
\hline County & Time with EIR & Time Without EIR & Difference \\
\hline Imperial & $90-120$ days & $15-60$ days & $2-3$ months \\
\hline Inyo & $\begin{array}{l}120-180 \text { days from } \\
\text { point of acceptance } \\
\text { EIR }\end{array}$ & $45-60$ days & 4-10 months \\
\hline Sonoma & 120 days minimum & 32 days minimum & 3 months \\
\hline Lake & 210 days minimum & 120 days & 3 months \\
\hline Napa & 4 months minimum & - & - \\
\hline Mendocino & $6-9$ months & $15-45$ days & $4.5-7.5$ months \\
\hline Colusa & Unknown & $30-45$ days & Unknown \\
\hline Lassen & Unknown & Unknown & \\
\hline Modoc & Unknown & 2 months minimum & $2-4$ months \\
\hline Plumas & 4-7 months & 2.5 weeks & 6.5 months \\
\hline Shasta & 7 months minimum & & \\
\hline Siskiyou & $3-8$ months & 1 month & $2-7$ months \\
\hline
\end{tabular}

Preparation by a county department tends to be less costly than when private consultants are employed. In addition to reviews of the EIR by local, state, and federal agencies, many counties require that the EIR be reviewed by a committee established for this particular purpose, to generate recommendations to the appropriate decision-making body. Preparation and review may takc 3-12 months. A common observation was the inordinate length of time required by the State Clearinghouse for an EIR review." The most unique approach to

* Section 15160 of the State EIR Guidelines provides for periods of from 30 to 90 days for public review of environmental documents. If a state agency issues a permit for a geothermal project, state law requires that state agencies review the document. In some instances local agencies set their own review period without considering the 45 days which state regulatory agencies require for their reviews. 
proparing and processing FiRs is in Sonoma County, which allows an applicant to have an liR prepared on a portion of the leasehold. As an EIR for each additional leasehold portion is completed it is added onto the existing EIR, which contains stipulations for the entire leasehold. This procedure allows a faster decision time for the subsequent EIRs. Inyo, Imperial, and Modoc Counties currently have geothermal energy ordinances. All of them are based upon the Imperial County Ordinance. Napa has an interim geothe rmal ordinance which prohibits all facilities for. production, generation, or transportation of geothermal power. Napa's proposed ordinance is also based upon that of Imperial County. Sonoma, Napa, Tchama, Plumas, and Lassen Counties are preparing energy extraction and production ordinances or energy elements to the General Plan of the county. Lake, Mendocino, Colusa, Siskiyou, and Mono Counties have no energy ordinances, and no current plans to develop same. Details of the ordinances are provided in the tables in the regional section. 
THE GEYSERS REGION

\section{REGIONAL OVERVIEW}

The region includes The Geysers-Calistoga, Knoxville, Little Horse Mountain, Lovelady Ridge, and Witte: Springs KGRAs and is located in portions of Colusa, Lake, Mendocino, Napa, Sonoma and Yolo Counties about 120 kilometers (75 miles) north of San Francisco. It ranges from the Witter Springs and Lovelady Ridge KGRAs, just north of Clear Lake, to the south end of The Geysers-Calistoga KGRA, west of Lake Berryessa. Route 101, between Ukiah and Santa Rosa, is to the west and Route 5 between Maxwell and Woodland to the east. The bulk of the region lies in Lake County but most development has occurred in Sonoma county. Figure 5-3 shows the overall region and the individual KGRAs.

In about 1880, resorts and health spas began to dot the hills south of Clear Lake. Hot springs in the vicinity of Lower Lake, Middletown, and Cobb Valley were a major attraction. In recent years, however, business at hot spring resorts has declined, and none of the former resorts are open today. However, a valuable source of heat still exists.

Since the discovery of The Geysers by a hunter in 1847, interest in using this source of natural energy has been high. Between 1921 and 1925, eight steam wells were drilled for generating electricity, but the project failed for lack of a nearby market. In 1955, Magma Power Company began drilling for steam. In June 1960, Pacific Gas and Electric Company's first power plant to operate on geothermal steam went on the line with $12.5 \mathrm{MW}$. Since then, 11 generating units with a total capacity of $502 \mathrm{MW}$ have made The Geysers the world's largest producer of power from geothermal energy.

Around Clear Lake in the northern part of the region the terrain is flat to rolling. To the south of Clear Lake, the terrain becomes more mountainous. The Mayacmas Mountains trend northwest-southeast through the southern half of the region. The major cultivated and urban areas are in the vicinity of Clear Lake. Orchards of pears, walnuts, and grapes are scattered throughout a 5-mile strip around the southern edge of the lake. A few orchards can even be seen on the steep sides of Mount Konocti, an extinct volcano on the shore of the lake. 
The permanent population living within the area is about 10,000 people. Most of these people live in a strip around Clear Lake and in the adjacent valleys where fruit and nut production occurs. A much lesser concentration of people occurs along Route 175 in the Cobb Mountain area. The rest of the region is very sparsely populated.

Lake County is the principal county of The Geysers-Calistoga KGRA. Because of the county's natural lakes and scenic mountains and its proximity to the San Francisco and Sacramento metropolitan areas, tourisin has become one of the major economic uses. Intensive recreation development has occurred mainly in two areas, Clear Lake and Cobb Mountain.

Clear Lake is the largest natural lake totally within California. Commercial development and the utilization of the lake's recreation resources commenced over 100 years ago. The southern part of the lake is within The Geysers-Calistoga KGRA and the surrounding land mostly is in private ownership. Federal ownership within 6.4 to 8 kilometers ( 4 to 5 miles) of this portion of the lake is nominal and in scattered tracts. Potential geothermal leasing for such lands would, in most instances, probably have to be accomplished in conjunction with adjacent private lands. Although only 20 percent of the lake is in the KGRA, it has about two-thirds of the lake's resorts, trailer parks, and related commercial facilities. Clear Lake State Park is located partially within the KGRA on the west side of the lake.

The forested Cobb Mountain area, near the center of the region, flourished as a resort area from 1870 to 1930. Adjacent to Cobb Mountain is the 3,300-acre Boggs Mountain State Forest which received 1, 870 recreation visitors in 1972. All of the State Forest and most of the adjacent Boggs Mountain area are within The Geysers-Calistoga KGRA. The balance of the KGRA, including Sonoma and Mendocino County sections, has very limited recreation

Fig. 5-3. KGRAs in The Geysers Region (opposite) 

use. The chaparral-covered hills and woodland-grass-covered valleys are used for hunting. Most of the land is privately owned with restricted public access. The scattered national resource lands, for the most part, do not have public access.

Private lands comprise a substantial portion of the total lands in The Geysers-Calistoga KGRA. The Fedoral Government has land in two types of ownership in the KGRA. Part of the area is national resource land (full fee ownership to the government). The other type of ownership is mineral rights only. The land area with federal mineral rights only is greater than that in full fee title to the government. Major federal ownerships are in the western and southern portions of the KGRA.

\section{KGRA DESCRIPTIONS AND RESOURCE ESTIMATES, FOR THE GEYSERS REGION}

A brief description of the location and basis for establishing the KGRA is given for each of the KGRAs in the region. An estimate of the extent of the resource and its potential is provided in Table 5-11. The KGRAs are presented alphabetically.

The Geysers-Calistoga KGRA

The Geysers-Calistoga KGRA consists of 378,687 acres located in sections of Lake, Mendocino, Napa, and Sonoma Counties. This KGRA has evolved from additions to The Geysers and Calistoga KGRAs causing them to coalesce into a single large KGRA. The initial KGRAs were located in northeastern Sonoma County (The Geysers) and in the north end of Napa Valley (Calistoga) between 97 and 113 kilometers (60 and 70 miles) north of San Francisco. An arm of the KGRA extends some 15 kilometers ( 9 miles) southeastward and encompasses the towns of Calistoga and St. Helena.

Geological indicia led to establishment of The Geysers and Calistoga KGRAs effective December 24, 1970. Later a review of the geology in the area between The Geysers and Calistoga KGRAs, subsequent to filing of noncompetitive lease applications in that area, indicated that the two existing KGRAs should be consolidated and that lands southeast of the Calistoga KGRA 
Table 5-11. Estimated energy potential, The Geysers Region KGRAs

\begin{tabular}{|c|c|c|c|c|}
\hline Location/KGRA & $\begin{array}{c}\text { Circular } 726 \\
\text { Designation }\end{array}$ & $\begin{array}{l}\text { Estimated } \\
\text { Reservoir } \\
\text { Temp. },{ }^{\circ} \mathrm{C}\end{array}$ & $\begin{array}{c}\text { Total } \\
\text { Reservoix } \\
\text { Heat } \\
\text { Content, } \\
\text { quads }\end{array}$ & $\begin{array}{l}\text { Electric } \\
\text { Energy } \\
\text { Potential, } \\
\text { MWe for } \\
30 \text { years }\end{array}$ \\
\hline \multirow[t]{5}{*}{ Geysers-Calistoga } & The Geysers & 240 & 75 & 1589 \\
\hline & Calistoga & 160 & 3 & 70 \\
\hline & Sulphur Bank Mine & 185 & $\sim 2$ & 37 \\
\hline & Skagg's Hot Spg. & 155 & 1 & 27 \\
\hline & Wilbur Hot Spg. & 135 & 10 & $\because$ \\
\hline \multirow{5}{*}{$\begin{array}{l}\text { Knoxville } \\
\text { Little Horse Mtn. } \\
\text { Lovelady Ridge } \\
\text { Witter Springs }\end{array}$} & One Shot Mining & 150 & $\cdots 1$ & $\therefore$ \\
\hline & Crabtree Hot Spg. & 150 & $\sim 1$ & $\because$ \\
\hline & Cook Springs & 140 & $\sim 1$ & $\because$ \\
\hline & & 140 & $\sim 1$ & $\therefore$ \\
\hline & & & 95 & 1722 \\
\hline
\end{tabular}

should be added to the new KGRA. Thus, the addition to, and consolidation of, The Geysers-Calistoga KGRA was determined on the basis of (1) favorable geothermal indicia and (2) competitive interest.

Knoxville KGRA

The Knoxville KGRA, containing 14,702 acres, of which 9,785 acres are National Resource Lands, is located in the northern Coast Ranges of California approximately 120 kilometers (75 miles) north of San Francisco and 16 kilometers (10 miles) east of the original Geysexs KGRA. The KGRA includes sections of Lake, Napa, and Yolo Counties. The small population center of Knoxville lies less than 1.6 kilometers (one mile) east of the proposed KGRA and is more or less a ghost town. The area is serviced by the BerryessaKnoxville, or Morgan Valley, Road. 
This KGRA is based on the filing of overlapping noncompetitive lease applications resulting in competitive interest, and is supported by geothermal indicia in the area.

\section{Little Horse Mountain KGRA}

The KGRA, consisting of 1,196 acres in Lake County, is 19.3 kilometers (12 miles) north of the town of Lucerne on Clear Lake. The land of the KGRA includes two sections in an east-west alignment. Approximately 1.6 kilometers ( 1 mile) to the northwest is Crabtree Hot Springs with a surface temperature of $41^{\circ} \mathrm{C}$.

Overlapping geothermal lease applications in the vicinity of Little Horse Mountain, Lake County, filed in January, 1974, indicated that competitive interest in the area exists. Designation of the area as a KGRA is based solely on competitive interest.

\section{Lovelady Ridge KGRA}

The Lovelady Ridge KGRA contains 6,879 acres in Colusa County and lies about 26 kilometers ( 16 miles) north by northeast of The Geysers-Calistoga KGRA. It is approximately 6.4 kilometers ( 4 miles) southwest of Lodoga. The dominating geographic feature in the KGRA is Lovelady Ridge, trending north to northeast. The KGRA is in mountainous terrain.

Lovelady Ridge KGRA is based primarily on competitive interest. Geothermal indicia, such as dissolved silica in the waters of Cook Springs and Deadshot Spring in the KGRA which indicate water source temperatures of $120^{\circ} \mathrm{C}$ and $100^{\circ} \mathrm{C}$, respectively, also lend support to the designation.

\section{Witter Springs KGRA}

The Witter Springs KGRA contains 18,152 acres in portions of Lake and Mendocino Counties. It is located a few kilometers northwest of Clear Lake in Lake County. Ukiah is approximately 19.3 kilometers (12 miles) to the southwest. 
Overlapping geothermal lease applications in the vicinity of Witter Springs filed during January 1974 indicated that competitive interest in the area exists. Witter Springs has consequently been designated a known geothermal resource area based solely on competitive interest.

COUNTY PERSPECTIVES - LAKE, NAPA, SONOMA, MENDOCINO, AND COLUSA: THE GEYSERS REGION

The five counties included in The Geysers Region have economies which are strongly influenced by agricultural production. In addition, Lake County receives significant revenues from tourism, Napa County has a significant working population (29\%) employed in the governmental market sector, and Sonoma and Mendocino Counties have large forest products industries. Sonoma currently receives sizable revenues from the operation of The Geysers $(\sim \$ 2.4$ million this year) and Lake is realizing much smaller revenues $(\sim 30-40$ thousand), but is looking to future ad valorem taxes on geothermal activities to significantly increase. Only Sonoma County encourages a growth perspective for population and employment opportunities. Each of the other counties is seeking to plan for and manage a slow-growth economy. Although some of these counties allow a variety of land uses, some actively discourage nonagricultural enterprises. Moreover, some of the counties are strongly committed to the preservation of open space.

This area should not be regarded simply as an agricultural community, particularly when evaluating the acceptability of geothermal energy development. It is, politically, a complex environment. These counties cover the spectrum of knowledge about, and acceptance of, geothermal development. Sonoma has had the greatest experience and is the most encouraging. Lake views geothermal development favorably, yet wants better environmental data before giving full acceptance to power plant development. ${ }^{*}$ Mendocino and Colusa counties appear

* Of particular concern in any expansion in the Geysers Region is the control of $\mathrm{H}_{2} \mathrm{~S}$ emissions. The Lake County Air Polution Control Board has recently (May 13) passed resolution 70137 which establishes new review rules for determining the impact of new sources of air contaminent emission on air quality. 
to have rather benign attitudes toward the development of geothermal energy, though the Mendocino County Counsel has in the past been very concerned about maintaining local control over such development. And Napa County might be characterized as being extremely reticent to allow any geothermal development. Thus it is, at the very least, difficult, if not patently inadvisable, to present or manage this region as a single undifferentiated entity. In order to more realistically appraise the opportunities for geothermal energy development in The Geysers Region, abbreviated snapshots of each county will be herein developed.

\section{Sonoma County}

Sonoma County is one of the fastest growing counties in California. It is a county seeking managed growth in its residential and market sectors. Only the City of Petaluma could be characterized as having a slow-growth attitude. For the rest of the county urban development will be kept to current urban centers in order to preserve the county's natural resources - agriculture, forest products, open space, geothermal steam fields - for appropriate development.

Among its natural resources geothermal steam is rated highly. The County General Plan has a specific section devoted to it. The Plan recommends the initiation of a comprehensive geothermal resource management program jointly funded by public and private resources. Though such a program is not yet begun, Sonoma County has been actively pursuing administrative procedures which will (1) provide a comprehensive data base upon which decisions can be made, (2) smooth the way for appropriate geothermal development, (3) provide for the protection of the environment, and (4) encourage multiple land use management of geothermal leaseholds.

\section{Procedural Requirements - Sonoma County}

Conditional use permits are required for all geothermal energy activities in Sonoma (Tables 5-12, 5-13, and 5-14). The application fee for a use permit is $\$ 75$, plus $\$ 50$ to process an environmental assessment. An Environmental Protection Committee (EPC), composed of the Departments of Planning, Public Works, the County Water Agencies, Environmental Health, and Regional Parks, 
Table 5-12. Use permit requirements, The Geysers Region - Sonoma, Lake, Mendocino, Napa, and Colusa Counties

\begin{tabular}{|c|c|c|c|c|c|c|}
\hline County & Use Permit & Activity Covered & Cost & $\begin{array}{l}\text { Decision Making } \\
\text { Time }\end{array}$ & Reviewing Agencies & Special Provisions \\
\hline Sonoma & $\begin{array}{l}\text { Conditional } \\
\text { Use permit }\end{array}$ & $\begin{array}{l}\text { Shallow temperature gradient } \\
\text { testing through utilization, as } \\
\text { specified }\end{array}$ & $\$ 75$ & $\begin{array}{l}32 \text { days, minimum } \\
\text { without } E I R\end{array}$ & $\begin{array}{l}\text { Board of Zoning } \\
\text { Adjustment } \\
\text { Planning Commission } \\
\text { Planning Agency }\end{array}$ & \\
\hline Lake & Use permit & $\begin{array}{l}\text { Exploratory well through } \\
\text { utilization, as specified }\end{array}$ & $\begin{array}{l}\$ 50 \\
\$ 5-20,000 \\
\text { for engineer- } \\
\text { ing inspector }\end{array}$ & $\begin{array}{l}4 \text { months, without } \\
\text { EIR preparation } \\
7-9 \text { months with } \\
\text { EIR preparation }\end{array}$ & $\begin{array}{l}\text { Planning Commission } \\
\text { Planning Department }\end{array}$ & $\begin{array}{l}\text { - Not required for } \\
\text { obtaining geophysical } \\
\text { data including resis- } \\
\text { tivity and heat probes } \\
\text { - } 10 \text { copies to planning } \\
\text { department } \\
\text { - Contract required } \\
\text { with engineering } \\
\text { inspector to assure } \\
\text { environmental } \\
\text { compliance }\end{array}$ \\
\hline Mendocino & Use permit & $\begin{array}{l}\text { Shallow temperature gradient } \\
\text { testing through utilization as } \\
\text { specified }\end{array}$ & $\$ 50$ & $\begin{array}{l}15-45 \text { days without } \\
\text { EIR preparation } \\
7-10 \text { months with } \\
\text { EIR preparation }\end{array}$ & $\begin{array}{l}\text { Planning Commission } \\
\text { Planning Department }\end{array}$ & \\
\hline Napa & Use permit & $\begin{array}{l}\text { Shallow temperature gradient } \\
\text { testing through utilization as } \\
\text { specified }\end{array}$ & $\begin{array}{l}\text { Included in EIR } \\
\text { costs }\end{array}$ & $\begin{array}{l}4 \text { months with } \\
\text { EIR preparation }\end{array}$ & $\begin{array}{l}\text { Conservation, } \\
\text { Development \& Planning } \\
\text { Commission } \\
\text { Planning Department }\end{array}$ & $\begin{array}{l}\text { - County wants lease } \\
\text { submitted with per- } \\
\text { mit application }\end{array}$ \\
\hline Colusa & Use permit & Specified by applicant & $\$ 10$ & $30-45$ days & $\begin{array}{l}\text { Planning Commission } \\
\text { Planning Department } \\
\text { Regional Water } \\
\text { Quality Control Board } \\
\text { Cal Dept. of Fish and } \\
\text { Game } \\
\text { APCD }\end{array}$ & \\
\hline
\end{tabular}


Table 5-13. EIR requirements, The Geysers Region - Sonoma, Lake, Mendocino, Napa, and Colusa Counties

\begin{tabular}{|c|c|c|c|c|c|}
\hline County & EIR Cost & Reviewing Agencies & Preparation by & $\begin{array}{c}\text { Decision Making } \\
\text { Time }\end{array}$ & Comments \\
\hline Lake & $\begin{array}{l}\$ 100 \text { application fee; } \\
\text { fee for EIR prepara- } \\
\text { tion placed on de- } \\
\text { posit by applicant }\end{array}$ & $\begin{array}{l}\text { Planning Commission } \\
\text { Planning Department } \\
\text { Other county agencies } \\
\text { State Clearinghouse }\end{array}$ & $\begin{array}{l}\text { Consultant contracted by } \\
\text { county }\end{array}$ & $\begin{array}{l}\text { 60 days to decide } \\
\text { on consultant, mini- } \\
\text { mum } 60 \text { days for } \\
\text { EIR preparation, } 60 \\
\text { days for review of } \\
\text { EIR; minimum } 6 \\
\text { months, total }\end{array}$ & $\begin{array}{l}\text { - No appeal on EIR } \\
\text { decision of Planning } \\
\text { Commission } \\
\text { - } 75 \text { copies submitted to } \\
\text { Planning Department }\end{array}$ \\
\hline Mendocino & $\begin{array}{l}\$ 100 \text { for application: } \\
\text { fee for preparation } \\
\text { determined by } \\
\text { contractor }\end{array}$ & $\begin{array}{l}\text { Planning Commission } \\
\text { Planning Department } \\
\text { Other county } \\
\text { departments } \\
\text { State Clearinghouse } \\
\text { Cal Fish and Game } \\
\text { Cal Division of } \\
\text { Forestry }\end{array}$ & $\begin{array}{l}\text { Applicant or contractor } \\
\text { to county }\end{array}$ & $\begin{array}{l}15-45 \text { days to point } \\
\text { of Negative Declara- } \\
\text { tion, } 3-6 \text { months for } \\
\text { preparation plus } 3 \\
\text { months for final } \\
\text { decision, total } 7-10 \\
\text { months }\end{array}$ & $\begin{array}{l}\text { - One geothermal EIR } \\
\text { has been done }\end{array}$ \\
\hline Napa & $\begin{array}{l}\$ 80 \text { for initial study } \\
\$ 250+\$ 1 / \text { acre for } \\
\text { preparation and } \\
\text { review plus fee } \\
\text { determined by con- } \\
\text { sultant (section } \\
15053 \text { Napa County } \\
\text { EIR guidelines) }\end{array}$ & $\begin{array}{l}\text { Conservation and } \\
\text { Environmental } \\
\text { Quality Committee } \\
\text { Planning Commission } \\
\text { Conservation Devel- } \\
\text { opment and Plan- } \\
\text { ning Department } \\
\text { plus other county } \\
\text { agencies, appeals to } \\
\text { Board of Supervisors }\end{array}$ & $\begin{array}{l}\text { Contractor to county } \\
\text { under } 2 \text { step bid } \\
\text { system }\end{array}$ & 4 months & \\
\hline Colusa & $\begin{array}{l}\$ 25 \text { for application } \\
\text { fee for preparation } \\
\text { determined by } \\
\text { contractor }\end{array}$ & Planning Department & Contractor to county & Unknown & $\begin{array}{l}\text { - No EIR prepared to } \\
\text { date } \\
\text { Thought to be } \\
\text { politically necessary } \\
\text { for geothermal } \\
\text { development }\end{array}$ \\
\hline Sonoma & $\begin{array}{l}\$ 50 \text { for application; } \\
\text { fee determined by } \\
\text { consultant and put on } \\
\text { deposit }\end{array}$ & $\begin{array}{l}\text { Planning Department } \\
\text { Environmental Pro- } \\
\text { tection Committee } \\
\text { - Planning Dept. } \\
\text { - Public Works } \\
\text { County Water } \\
\text { Agencies } \\
\text { - Department of } \\
\text { Environmental } \\
\text { Health } \\
\text { - County Regional } \\
\text { Parks Department }\end{array}$ & $\begin{array}{l}\text { Consultant contracted } \\
\text { by county }\end{array}$ & 4 months, minimum & $\begin{array}{l}\text { - Applicant may elect to } \\
\text { have EIR prepared on } \\
\text { entire lease, or a } \\
\text { portion } \\
\text { - Minimum area for } \\
\text { assessment } 400 \text { acres } \\
\text { (accommodates full } \\
\text { production and } \\
\text { cluster) } \\
\text { - EIR contains conditions } \\
\text { on entire leasehold } \\
\text { - Additional wells only } \\
\text { require addenda to } \\
\text { original EIR }\end{array}$ \\
\hline
\end{tabular}


Table 5-14. Energy regulations, The Geysers Region - Sonoma, Lake, Mendocino, Napa, and Colusa Counties

\begin{tabular}{|c|c|c|c|}
\hline County & Energy Regulations & Date & Comments \\
\hline Sonoma & Energy Ordinance in Preparation & & - Not likely to be on the books soon. \\
\hline Lake & None & & $\begin{array}{l}\text { - Would require an EIR to put geothermal element } \\
\text { into general plan. Does not have money to under- } \\
\text { take EIR. }\end{array}$ \\
\hline Mendocino & vione & & r \\
\hline Napa & $\begin{array}{l}\text { Ordinance Number } 453 \\
\text { Oil, gas, and geothermal resource explora- } \\
\text { tion and development ordinance - proposed }\end{array}$ & $\begin{array}{l}\text { May, } 1974 \\
\text { Draft approved } \\
\text { January } 7,1973\end{array}$ & 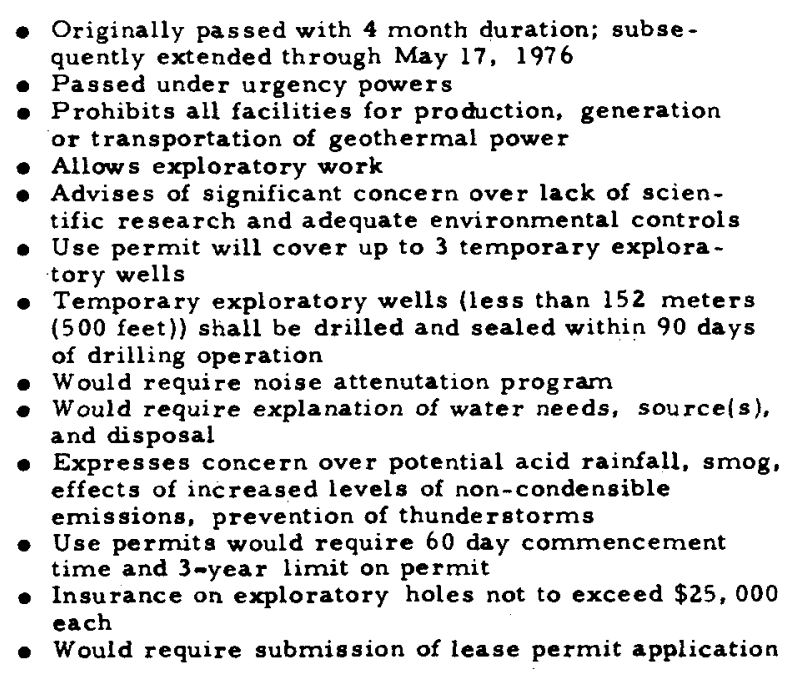 \\
\hline Colusa & None & & \\
\hline
\end{tabular}


reviews permit applications for each discretionary project. It makes recommendations to the department wherein the application originated on the acceptability of the proposed projects. The decision by the EPC cannot be appealed. The responsible department may elect to approve or disapprove a project irrespective of the EPC's decision to is sue a Negative Declaration or require an EIR. In addition to the EPC all permits are reviewed by the Board of Zoning Adjustment or the Planning Commission. The Planning Commission primarily reviews subdivision proposals and ordinances. Use permits and EIR hearings are held simultaneously. If an EIR is determined to be required, the applicant is required to put on deposit funds to pay for a consultant contracted by the county (Table 5-13). Bidding procedures on the EIR preparation may or may not take place. In either case, the county is the final judge on contractor selection. The applicant has the option to pay for an EIR on the entire leasehold or a portion not less than 400 acres. Full production and a cluster can be accommodated on this size parcel. The cost of an EIR is quite variable. On one parcel of about 8,000 acres, a deposit of $\$ 50,000$ was made by Union Oil.

The method selected by Sonoma for EIR preparation is seemingly unique compared to other counties surveyed for this study. An EIR is prepared in stages using a worst case analysis technique to appraise environmental impacts of a proposed activity. The original EIR on a leasehold will detail the conditions with which there must be a compliance in order to develop the full potential of a lease.

When an applicant seeks to develop subsequent wells, on adjacent parcels within the leasehold, only an addendum to the original EIR is required. This procedure eliminates duplication in impact report writing and evaluation, as well as speeding up the decision-making time. As a result of the Sonoma procedures, 19 permits were issued in 1974 to Union Oil Company. It was possible to do so many because of the practice of preparing a leasehold EIR and doing analysis on a site-specific basis for wells as Union Oil was ready to develop them. According to one county representative, the EIR does not currently hinder or delay geothermal energy exploration and production. It was suggested that any delays potentially attributable to CEQA can essentially be avoided by planning for EIR requirements as a part of the necessary lead time to a project, the same as one plans for well casings and valves. 
Processing of EIRs includes review by the State Clearinghouse and the State Lands Commission. Each add one month to the decision-making time. Cordial relationships exist between the county and the state agencies. Nonetheless, it is felt that the review process employed by them could be shortened by better than 50 percent. One of the options proposed by the county is for the State Lands Commission to set general standards and treat permit applications by exception. In addition, an appropriate review procedure would provide assistance, as well as having the State Lands Commission meet more frequently than once per month. There appear to be good working relationships with BLM and USGS.

\section{Significant Issues - Sonoma County}

Sonoma officials are deeply concerned that The Geysers KGRA have an integrated administrative unit which would have representation from Sonoma, Lake, and Napa Counties, the two APCDs (North Sonoma and Lake), the Regional Water Quality Control Boards, USGS, BLM, and other responsible agencies. Sonoma, particularly, receives significant revenues from the operations at The Geysers which they hope to see increased, but only under careful management of the resource in balance with other priorities in the county previously mentioned. Sonoma desires to maintain a voice in the management of its geothermal resources to ensure this balance. However, concern has been expressed that unless there is a mechanism for cooperative planning, the state and/or federal government will use their powers of preemption to resolve the difficulties in the use of the resource. Therefore planning officials in Sonoma have been working over the last two years to create such a mechanism. This aim to promote cooperative planning has been a strong factor in refining the EIR preparation and review processes.

\section{Lake County}

Geothermal energy development is a prominent issue in Lake County. Of the 256,000 acres in the original Geysers KGRA, 175, 000 acres are in Lake County. The county has a decided interest in the development of the KGRA. It generally is in favor of the development, but wants it done in an orderly fashion, ind only if development will not harm existing commercial enterprises. The 
Lake County approach is a mildly cautious one wherein a decision has not been reached in respect to full production and utilization, but the data necessary to reach such a decision is being actively sought.

\section{Procedural Requirements - Lake County}

The county enters into the geothermal regulation process when an applicant desires to drill an exploratory well. Geophysical data gathering, including resistivity and heat probes, do not require county approval. (The Division of Oil and Gas must approve heat probes.) Application for a use permit, at a cost of $\$ 500$, must be made to the Planning Department. Lake uses the EIR, if required, as a basis for issuing a use permit. The cost for EIR determination is $\$ 100$. Only one Negative Declaration has been issued. There are other areas which are felt not to be environmentally sensitive for which Union Oil and Burma have expressed an interest in having a Negative Declaration made. However, the county is waiting to see the political results of the first such declaration before proceeding with any others. It is felt that the Resources Agency would not be amenable to Negative Declarations on any geothermal project for precedential reasons.

EIR preparation is contracted for by the county. Contracting can be done on either a sole source or bid procedure. Payment for the EIR must be placed on deposit upon selection of a consultant before any work will be allowed. Costs have ranged from $\$ 5,000$ to $\$ 50,000$. It is the joint responsibility of the Planning Department and the operator to ensure completion of the EIR. Conferences with the consultant, the Planning Department, and the developer are held to expedite preparation. The time from initial application for a use permit to the scheduling of a hearing on the EIR is highly variable. Historically, the process has taken from 5-8 months. One of the variables is the time it takes an applicant to place the EIR fee on deposit. In one instance this was 6 weeks. However, once the final EIR is accepted, the decision on the use permit is almost perfunctory. The issues have been largely aired and resolved in the preparation and review of the EIR. An additional provision in the geothermal developer's use permit is the requirement of an engineering inspector to ensure compliance with environmental regulations, contracted by the developer. This has cost from $\$ 5,000$ to $\$ 20,000$. 
The relationship with BLM has been described as cooperative. However, that with USGS was noted as being strained. USGS is seen as being somewhat indifferent to county desires. The county is concerned about site inspection which it feels is largely unattended to by USGS. BLM is credited with being at the site more frequently, though not frequently enough to suit the county. Relationships with the state are cordial, but the assistance offered to the county has been strongly criticized. The Department of Fish and Game has taken the posture that no comment will be offered unless an EIR examines an entire field. The Division of Oil and Gas is criticized for the lack of resident site inspection. Only the Regional Water Quality Board was praised. Lake hopes to be part of a four-county coordinating council on geothermal energy.

\section{Significant Issues - Lake County}

Lake County is currently insisting that any geothermal activity be conducted under sound environmental protection practices. It is enjoying some return to county coffers from existing operations, which it hopes to see augmented in the future. Lake, like Sonoma County, is concerned lest the state and/or federal governments use their powers of pre-emption. In the view of one county employee, without the ad valorem tax on geothermal energy, there is no benefit to the county in its development. The county wants to remain a part of decision-making process. It currently asks operators (all on federal leases) to comply with county regulations. Some have chosen to apply for the permits, others have not. Lake has not written a special ordinance governing energy development. It is felt that an EIR would be necessary to do so, for which the resources are unavailable. However, should one be done, it is viewed as a joint responsibility of the state, federal, and local governments.

\section{Mendocino County}

Mendocino County has a population of 55,000 people. The primary indus try is forest products, followed by the wine (viticulture) industry. The county is receptive to the introduction of new light industries which are compatible with the environment, and are more capital-intensive rather than labor-intensive. This is a county favoring slow growth. It has had limited experience with geothermal energy exploration. Administrative response to geothermal energy 
extraction would likely be predicated on experiences with oil drilling. The county is apparently not yet prepared to take a position on energy development. No energy extraction or development ordinances have been enacted.

Procedural Requirements - Mendocino County

Use permits would be required for exploratory activity. Application for a use permit, plus determination of the EIR requirements, costs $\$ 50$. Application for EIR preparation costs $\$ 100$. EIRs are prepared by either a contractor to the applicant or to the county. One geothermal energy EIR was done for Sun Oil, Co., in 1974, for two exploratory wells.

It takes between 15 and 30 days to decide upon a Negative Declaration. When state agencies are involved it increases this to 45 days, on the average. Three to 6 months are required for preparation of the EIR, plus 3 months for review and final EIR decision. Total elapsed time is 7 to 10 months. It was stated that there are difficulties in getting responses from state and federal agencies in a reasonable time frame on Negative Declarations or EIRs.

\section{Significant Issues - Mendocino County}

There are three geothermal energy related issues which have been brought up by the Board of Supervisors. The first is of a general nature, should the county actively encourage and support development? Second, when is the best time to do an EIR? Should it be done as a phased activity, or should it examine the project through the potential of utilization? Third, how shall the county pass on all costs for energy extraction to the developer and user? Although no firm answers have yet emerged, the issues have been raised. These questions are clearly not unique and may find some resolution by examining the solutions adopted by others.

In addition to these issues, home rule is a theme of much prominence. Mendocino would like to have county regulations followed on state and federally managed lands. It also recognizes that should energy companies have significant difficulty in obtaining county permits that the powers of pre-emption could be used to remove such regulatory authority from county government. Disagreement has arisen between state and local government over which has the greater 
responsibility for permit approval. The County Counsel advised in 1973 that Mendocino County has the greater responsibility for approving geothermal projects, than does the Division of Oil and Gas, and has general rather than single purpose governmental powers. Thus it was concluded that the County of Mendocino is clearly the lead agency for exploration and development. The Division of Oil and Gas has obtained a decision from a state Deputy Attorney General which refutes this interpretation. This issue - brought up also in Napa County - is yet to be satisfactorily resolved.

Colusa County

Colusa County has a population of approximately 12,400, a level which has not changed in the last 40-50 years. There are some strong no-growth advocates. It is the center of short-grain rice production in the United States. Colusa is usually in the top $5 \%$ per capita income in California. It has not had much familiarity with geothermal energy, with the exception of a conference held in Lake County in 1975. There has been some exploratory drilling, though the county is unaware of who is the operator. No special energy ordinances have been enacted.

$\underline{\text { Procedural Requirements - Colusa County }}$

Energy exploration and production activities would require a use permit. The application fee is $\$ 10$; and environmental analysis application fee is $\$ 25$. If an EIR is required, a consultant would be secured through a bidding process. No EIR has yet been prepared in Colusa. Geothermal energy would probably require an EIR on political grounds, if not for environmental reasons. Activities which are not directly related to agricultural processes are strongly

\footnotetext{
* According to Section 15065 of the State EIR Guidelines, the county is the lead agency for geothermal exploration, and according to Section 25519(c) of the Public Resources Code, the State Energy Commission is the lead agency for the power plant and related facilities. The major issue is not whether the county or DOG has greater responsibility for permit approval, but whether the Energy Commission's responsibility extends to the approval of drilling activities at some point in the exploration and $\mathrm{d}$ rilling development process.
} 
discouraged. However, an opinion was expressed indicating a sympathetic reaction to geothermal energy, particularly as a displacer of natural and bottled gas for home heating.

\section{Significant Issues - Colusa County}

There appear to be limited barriers to the development of geothermal energy in Colusa County. Access to viable areas may be the most significant constraints. If much population growth were to occur from geothermal energy development, a controversy would likely occur. Currently there is a housing shortage which has displaced local employees to adjacent communities. There is major attention focused on the preservation of open space that is not in agricultural production, through the mechanism of the Williamson Act. Under this Act the smallest parcel it is possible to develop is 80 acres. The taxes on lands under Williamson contract are assessed on the return of the property not on potential land use. Contracts must be made for 10 years, with renewal of one year for every year thereafter. Nonelectric geothermal uses would be permitted on these lands.

\section{Napa County}

Napa County's 513,000 acres of land and water consist mostly of mountain ridges and narrow valleys stretching across the county on a northerly-southerly axis. Scarcely one-third of the land in the county is level enough for conventional development, and only a little of the level land is located along the main east-west route connecting major population centers located outside of the county. Largely for these reasons, Napa County still retains much of its rural character and agricultural productivity.*

The population of Napa County is about 87,000. It tends to favor a slowgrowth perspective with further urbanization to be contained in existing urban centers. Agricultural interests predominate, though agriculture accounts for

\footnotetext{
"* Land Use Element, Napa County General Plan, As Amended December 1975, Napa County Conservation Development and Planning Commission.
} 
only 6 percent of the labor force. Government employment is the largest sector, comprising 29 percent. New commercial activities would have to be consistent with policies for limited growth and agricultural preservation. The current approach to geothermal energy development may be characterized as extremely guarded.

\section{Procedural Requirements - Napa County}

A use permit is required for all stages of geothermal energy exploration and development. In addition, the Planning Department is required to do an environmental analysis to determine if an EIR would be required. The use permit application fee and the fee for determining the necessity of an EIR is $\$ 80$. Fees for, EIR preparation and review are $\$ 250$ plus $\$ 1 /$ acre to the county, plus the fee for a consultant to prepare the report. Use permits and EIRs are simultaneously processed. Decision-making time from preparation to adoption of the final EIR is about 4 months.

Selection of a consultant is accomplished through a two-tier bidding process. A proposal is requested from two or three EIR consulting firms. After selection by the county, the consultant's bid is reviewed by the applicant. If the cost is unacceptable to him, the bidding process is repeated. Should the. outcome of the second bid selection remain unsatisfactory, the use permit becomes inactive.

The county has a Conservation and Environmental Quality Committee, which hears the EIR. The committee is composed of private citizens, one member of the Board of Supervisors, two geologists, a representative of the Grape Growers Association, the Sierra Club, the California Department of Parks and Recreation, and the Department of Fish and Game. Recommendations are made by this committee to the Planning Commission. In addition, county agencies will be asked to make comments on the EIR. Comments by these agencies are presented through the aegis of the Planning Department.

Evidence that the Regional Water Quality Control Board is reviewing a waste water management plan for the project is required. For well drilling an additional permit is required from the Department of Environmental Health. 


\section{Energy Ordinances - Napa County}

Napa is currently operating under an ordinance passed in May 1974 for the regulation of geothermal energy development. The ordinance expires May 17, 1976. Passed under urgency powers by county government, the ordinance (No. 453) prohibits all facilities for the production, generation, or transportation of geothermal power. Exploratory work is permitted.

The county is currently considering an Oil, Gas and Geothermal Resource Exploration and Development Ordinance. The draft was approved on January 7 , 1976. For a county that currently has no geothermal activity, the proposed ordinance has some rigorous conditions. It states that the county has significant concern over the lack of scientific research and adequate environmental controls. The specters of acid rainfall, smog, effects from increased levels of noncondensible emissions and thunderstorm prevention are raised. The proposed ordinance, in part, would require (1) that exploratory wells (less than 152 meters ( 500 feet)) be drilled and sealed within 90 days of the initiation of drilling, (2) that a noise attenuation program be approved, (3) that there be insurance on each exploratory hole, not to exceed $\$ 25,000$ each, (4) that a lease be submitted with the use permit application, (5) that use permits cover only up to three exploratory wells, (6) that use permits require commencement of operation within 60 days, and (7) that permits expire and the permit conditions be reexamined at 3 years.

\section{Significant Issues - Napa County}

Napa strongly desires to remain a vital part of the geothermal energy decision-making process in its own jurisdiction. Even so, the issue of local authority on federally managed lands does not appear to be critical. It would appear that consultation with federal agencies: would be sufficient, along with strict controls on private lands within the county. Mitigation measures rate highly as an issue, particularly in regard to $\mathrm{H}_{2} \mathrm{~S}$ and $\mathrm{SO}_{2}$ emissions from the Geysers. Citizens of Calistoga have expressed concern over the disposal of spent wastes into the local water system. Most importantly, Napa wants to avoid being the king's taster for geothermal energy development - an activity viewed here as novel, expensive, and potentially harmful. It does not want to be prematurely committed to a 30 -year activity. 


\section{GEOTHERMAL DEVELOPMENT STATUS IN THE GEYSERS REGION}

The Geysers Region is in the most advanced state of geothermal development of any region in California. It is the only region in which geothermal energy is currently being converted into electricity. This has come about through extensive development of the steam field in The Geysers-Calistoga KGRA. Although the region contains five KGRAs, all development has taken place in The Geysers-Calistoga area. Exploration and development has been recorded at The Geysers, Calistoga, and Clear Lake areas. Little or no activity has been reported at the other KGRAs.

Interest in geothermal power generation during the 1950 s prompted active leasing in The Geysers area north of Big Sulfur Creek. A total of 11 wells were drilled from 1955 through 1959, the deepest of which was 428 meters ( $1,404 \mathrm{feet}$ ), and in June 1960 a $12.5 \mathrm{MW}$ generating plant utilizing $250,000 \mathrm{lb} / \mathrm{hr}$ of steam from four wells was operational. In addition, several wells were drilled in the vicinity of Clear Lake, several townships to the north. They produced sizeable flows of thermal fluids and extended the area of geothermal interest.

Continued exploration and drilling activity in the area increased productivity over the next decade until The Geysers geothermal field became the world's largest steam field on November 30, 1973, when Pacific Gas and Electric Company's Powerplant Unit 10 was put on line. The total electric generating capacity in the field at the end of 1973 was $412.5 \mathrm{MW}$ which surpassed the former world leader, Italy, by 6.9 MW. Capacity remained at this level until 1975 when Unit 11 went into operation and capacity reached $502 \mathrm{MW}$.

Also in 1973 Union Oil Company completed a well to a depth of 2,899.1 meters $(9,509 \mathrm{ft})$ making it the world's deepest producing steam well. Concurrently, Pacific Energy Corporation completed drilling 10 wells which were shut in, pending construction of Powerplant Unit 15, for which a construction permit had not yet been issued by the California Public Utilities Commission.

Development activity at The Geysers intensified in 1974; however, PG\&E's Powerplant Unit 11 did not go on line in 1974 as scheduled because of delays caused by environmental, legal, and labor problems. It was scheduled for operation in May 1975 to bring the net capacity of The Geysers to $502 \mathrm{MW}$. 
Construction of Units 12, 13, and 14 was scheduled to start in 1976. The net capacity of these plants will be 106,135 , and $110 \mathrm{MW}$, respectively. Unit 15 , scheduled to start construction in 1977, will have a net capacity of $55 \mathrm{MW}$. Unit 12 is scheduled to be on line March 1978, Unit 15 in September 1978, Unit 14 in November 1978, and Unit 13 in February 1979.

Increased activity included action by the Santa Clara City Council to approve, in concept, a $\$ 670,000$ appropriation toward the exploration for steam in The Geysers. Santa Clara's appropriation will be part of a $\$ 2$ million proposed package to be put together by the Northern California Power Agency, an association of 11 cities mostly in Northern California. The 11 cities are Santa Clära, Alameda, Biggs, Gridley, Healdsburg, Lodi, Lompoc, Palo Alto, Redding, Roseville, and Ukiah.

The following year, in April 1975, Burmah Oil and Gas Company successfully completed two wells in the Castle Rock Spring area to supply PG\&E Plant 13. The wells a re the 15 th and 16 th productive geothermal steam wells brought in by Burmah Oil and Gas and are the most southerly producing wells in The Geysers area. Both wells are on federal land leased from BLM.

Shell Oil Company is also drilling in The Geysers area on federal land leased from BLM. Shell's first test well on the tract was drilled to a depth of 2560 meters $(8,400 \mathrm{feet})$ in 1975, but operations on that well were suspended. Another exploratory well drilled in 1975 has indicated commercial quantities of steam. Shell owns 100 percent of the leases covering some 4,000 acres in the vicinity of the exploratory well. These leases were obtained from BLM at a 1974 lease sale for bonuses totaling \$4,500,000. Table 5-15 summarizes the drilling activities, and operators involved, in The Geysers Region.

Thermal springs in The Geysers-Calistoga KGRA have also been used for non-electric applications of the geothermal resource in the Calistoga and Clear Lake areas. Calistoga, with a population of about 2, 000, has long had a reputation as a health resort. The town has many hotels and spas advertising hot mineral baths and, despite the decline of other northern California spas, has maintained a brisk business. Thermal water is found largely in two major areas in Calistoga: in the center of town, and near Tubbs Lane ( 1.5 kilometers ( 1 mile) west of town). The latter area includes a "geyser". Over 60 wells tap the hot water in the first area for use in health spas, for heating swimming 
Table 5-15. Wells drilled, The Geysers Region, 1971-75

(based on files of Division of Oil and Gas)

\begin{tabular}{|c|c|c|c|c|c|c|c|}
\hline Operator & Pre -1971 & 1971 & 1972 & 1973 & 1974 & 1975 & $\begin{array}{l}\text { Totals } \\
1971-75\end{array}$ \\
\hline Union Oil Co. of Calif. & 69 & 8 & 11 & 13 & 15 & 14 & 61 \\
\hline Burmah Oil and Gas Co. & 8 & 1 & 0 & 3 & 4 & 5 & 13 \\
\hline Pacific Energy Corp. & 6 & 2 & 3 & 2 & 3 & 2 & 12 \\
\hline $\begin{array}{l}\text { Geothermal Kinetics } \\
\text { Systems Corp. }\end{array}$ & & & & I & & & 1 \\
\hline Shell Oil Co. & & & & & & 2 & 2 \\
\hline Getty Oil Co. & & & 1 & & & & 1 \\
\hline Sun Oil Co. & & & & & 1 & & 1 \\
\hline $\begin{array}{l}\text { Sulphur Bank Geothermal } \\
\text { Power Co. }\end{array}$ & & 1 & & & & & 1 \\
\hline E. B. Towne & & & 1 & & & & 1 \\
\hline Cordero Mining Co. & 1 & & 1 & & & & 1 \\
\hline Others (Pre-71) & 15 & & & & & & \\
\hline Totals & 99 & 12 & 17 & 19 & 23 & 23 & 94 \\
\hline
\end{tabular}

pools, for domestic hot water, and for a water-bottling company. About 20 wells have been drilled in the second area for similar uses. Two of the wells are used sporadically for heating greenhouses. Calistoga's "Old Faithful" geyser (a 30meter (100-foot) deep well), blowing steam and hot water up to 12 meters (39 feet) above the ground every 35 to 50 minutes, is operated as a tourist attraction.

In the Clear Lake area a winding back road from Lower Lake to Middle-. town passes Siegler Springs, Howard Springs, and Harbin Springs, formerly the sites of large resorts. Howard Springs Resort is idle, and the owner apparently has no plans for future use of the property. Anderson Springs and Castle Rock Springs, 8 to 10 kilometers (5 to 6 miles) northwest of Middletown, were both popular with hot spring enthusiasts at one time. The Anderson Springs area is now a vacation home and retirement community, and the springs are not being used. Castle Rock Springs is presently a summer camp. The Geysers geothermal field extends at least as far south as Castle Rock Springs; the road to the springs passes several recently drilled steam wells.

Many warm springs surround Big Valley just south of the main part of Clear Lake including Highland Springs, Carlsbad Springs, Soda Bay Springs, 
and several springs on the shore of Dorn Bay. Highland Springs and Soda Bay Springs have been used sporadically for bathing. All of the springs have low temperatures and low flow rates.

Outside The Geysers-Calistoga area there is no known geothermal exploration or development in the other KGRAs in the region. Knoxville, Little Horse Mountain, Lovelady Ridge, and Witter Springs KGRAs remain to be developed. 
IMPERIAL VALLEY REGION

\section{REGIONAL OVER VIEW}

This region contains seven KGRAs: Brawley, Dunes, East Mesa, Ford Dry Lake, Glamis, Heber, and Salton Sea. All are in Imperial County except Ford Dry Lake, which is in the southwest corner of Riverside County. The Imperial County KGRAs extend from the Salton Sea KGRA on the northwest, south to Heber on the west and Dunes on the east. The Salton Sea KGRA is located at the southeastern end of the Salton Sea, whereas Heber, East Mesa, and Dunes KGRAs parallel the United States-Mexico border. The region is bounded by the Chocolate Mountains on the east and by Route 86 between Salton City and El Centro on the west. Ford Dry Lake KGRA is to the northeast, straddling Interstate Route 10 at the southeastern end of the Chuckwalla Valley about 40 kilometers (25 miles) west of Blythe. A map of the region showing the KGRA boundaries is presented in Fig. 5-4.

These KGRAs with the exception of Ford Dry Lake, are located in a closed-drainage basin with all drainage into the Salton Sea. The area is rather flat, arid, and surrounded by rugged mountains.

Elevations vary from several thousand feet in the surrounding mountains to a low of 85 meters (278 feet) below sea level in the Salton Sea. The area has a characteristic desert climate, with hot, dry summers and mild winters. Temperatures of over $38^{\circ} \mathrm{C}$ typically occur more than 100 days each year, and precipitation averages less than 3 inches annually, occurring largely in the fall and winter months. There are about 12 days of frost each year. The re is little fog, few thunderstorms, and winds vary from light to strong, predominantly coming from the west and northwest. Considerable smog is generated locally from burning stubble fields and smog drifts in from the Los Angeles area when air currents flow in a southwesterly direction.

Imperial Valley is a sediment-filled, northwesterly trending, structural trough called the Salton Trough. The entire depression is filled primarily by deltaic deposits of the Colorado River, but includes some lakebed and marine deposits. The valley is bordered on the nor theast and southwest by mountains composed of crystalline rocks and marine and nonmarine sedimentary rocks. 
Water in the Imperial Valley occurs in a desert environment modified by extensive agricultural development that depends on imported surface water. Sources of water in the area include precipitation (less than 8 centimeters ( 3 inches) per year on average), ground water, and imported surface water from the Colorado River. The Salton Sea forms a sump for water in the area tributary to the sea, including the Coachella Valley to the north. Water leaves the sea only by evaporation.

The Salton Sea is about 58 kilometers long and 19 kilometers wide ( 36 miles long and 12 miles wide). Topography in the vicinity of the sea is flat. It was formed when record flood crests of the Colorado River spilled into the Imperial Valley in 1905-07. Since then the sea has been maintained by natural runoff and irrigation return flows. Natural drainage is principally through the Alamo and New Rivers and artificial drainage occurs through numerous irrigation canals and drains that traverse the irrigated area.

The Salton Sea KGRA, the largest KGRA in the region, consists of 95, 824 acres, approximately 50 percent of which lies underwater within the present Salton Sea lakebed. Onshore, more than 95 percent of the land is under private control, with only scattered federal acreage in the nor thern end. Offshore, less than half the lake bottom is federally controlled, and a portion of that is wildlife refuge or Navy seaplane landing areas or mine laying areas. In addition, some of the federal offshore lands are in dispute with the Imperial Irrigation District as to ownership. All of the present geothermal discoveries are in the southern third of the KGRA. All are onshore and on private lands. Federal land holdings are primarily in the northern offshore portion of the KGRA.

The principal land use and industry in the Imperial Valley is (irrigated) agriculture. Agricultural products comprise a variety of field, vegetable, seed,

Fig. 5-4. KGRAs in the Imperial Valley Region (opposite) 


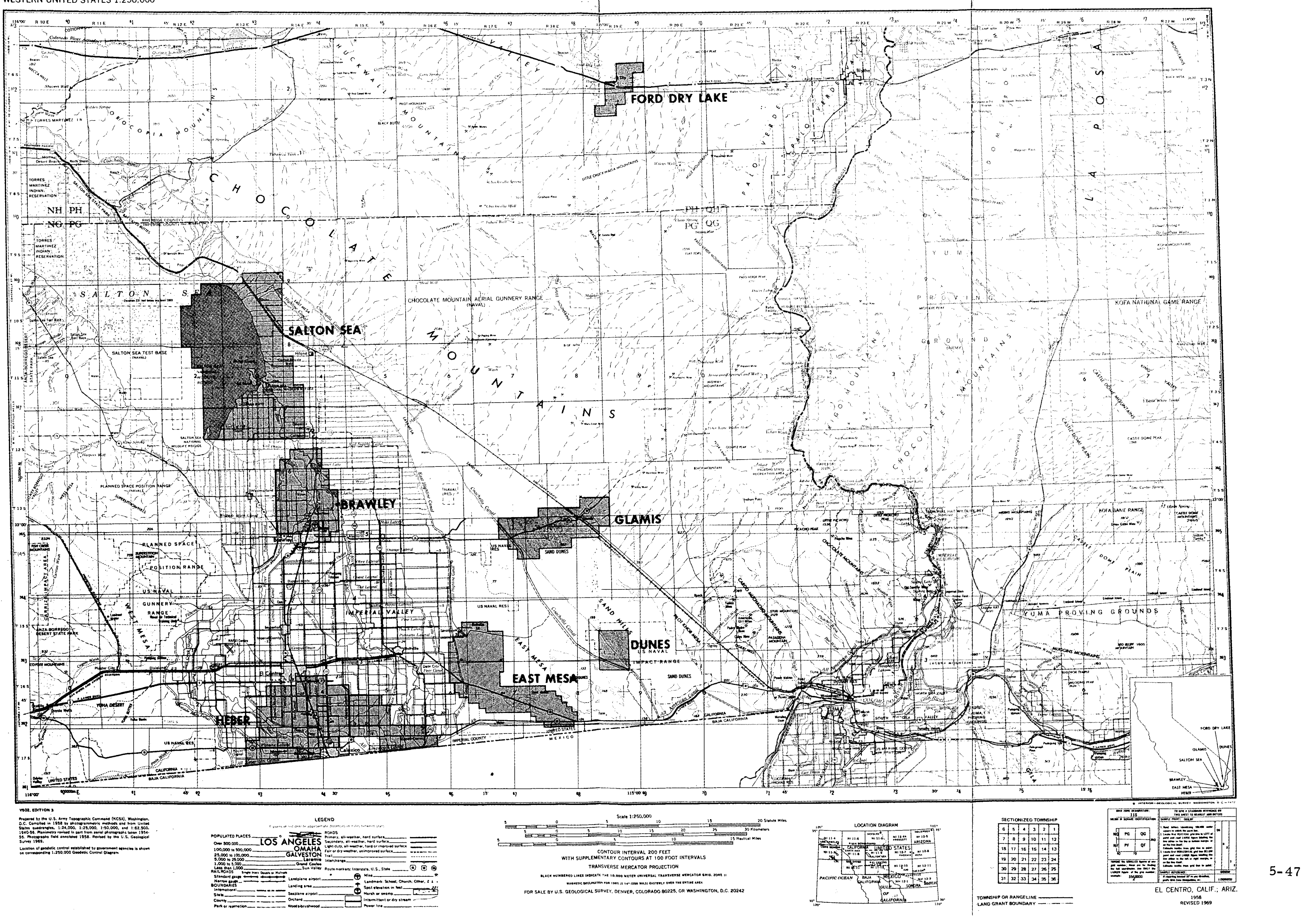


and nursery crops as well as apiary, livestock, and dairy products. Water from the Colorado River, delivered through the All-American Canal System, currently supplies some 500,000 acres in the Imperial Valley and Coachella Valley. In Mexico, the Alamo Canal and ground water pumping supply water to 400,000 acres in the Mexicali Valley. Highly productive soils and a 365-day-per-year growing season account for agricultural production of more than $\$ 300$ million annually in Imperial Valley. This industry is entirely dependent upon the successful management of the irrigation systems and the disposal of irrigation wastes.

One potential hazard to the industry is the threat of land subsidence through either tectonic action or groundwater development, either for geothermal power or for water supply. Whenever fluids are extracted from a groundwater reservoir-that is, withdrawals exceed the recharge and the reservoir pressures continue to decline-land subsidence may occur. Throughout much of the developed area of the Imperial Valley, subsidence could cause costly damage, mainly through change of grade of irrigation canals and drainage ditches, and through change of slope of farm lands and underground tile drains, both of which are laid to specific grades. In outlying undeveloped areas, however, subsidence might be tolerated.

The California Department of Fish and Game and U.S. Fish and Wildlife Service operate wildlife management areas on the southern end of the Salton Sea. Both are oriented toward providing resting and feeding areas for migratory waterfowl which travel the Pacific Flyway. The 3,900-acre Wister Unit of the state's Imperial Wildlife Management Area is located here. The U.S. Navy operates the Salton Sea Test Base, which includes about 51, 000 acres of land and water in the southern end. Approximately 16 kilometers (10 miles) of shoreline is located within the base. Activities relate primarily to testing of military equipment.

Most of the land in the Imperial Valley area is private surface and mineral estate. The irrigated land on the valley floor, between the East Highline Canal and the West Main Canal, is mostly privately owned. The bed of Salton Sea is largely natural resource lands; however, the lands in the Salton Sea National Wildlife Refuge are excepted from government leasing, and much of the rest of the federal land is withdrawn from entry. 
The East Mesa KGRA consists of 38, 365 acres, of which approximately 90 percent is federal land. All of the federal land is under Bureau of Reclamation withdrawal and cannot be leased unless the Bureau of Reclamation considered such action as being compatible with the purpose for which the land was withdrawn and with current Bureau programs in the area. All leasing would be by competitive bidding.

Land use in the East Mesa KGRA is primarily recreational; for example, off-road vehicular use by motorcyclists. Mineral materials extraction is also common along the shoreline of ancient Lake Cahuilla, where sand and gravel deposits are mined.

Recreation is the primary land use in the Glamis and Dunes KGRAs; specifically, off-road vehicle use by dune buggies. Use on winter holiday weekends is as high as 25,000 to 35,000 visitors, with most of the use concentrated in the Glamis KGRA. Other recreational uses in the se KGRAs include sightseeing, photography, camping, rock collecting, and fishing and swimming in the Coachella Valley. Study and research activities are conducted in the KGRAs by local universities.

\section{KGRA DESCRIPTIONS AND RESOURCE ESTIMATES FOR THE IMPERIAL VALLEY REGION}

A brief presentation of the location and basis for establishing the KGRA is given for each of the KGRAs in the region. An estimate of the extent of the resource and its potential is provided in Table 5-16. The KGRA's are presented alphabetically.

\section{Brawley KGRA}

The Brawley geothermal area, containing 28,885 acres in Imperial County, is in the southern part of the Imperial Valley about 32 kilometers (20 miles) north of the Mexican border. The area was designated as a KGRA on the basis of geothermal indications. A few small surface manifestations of geothermal activity are located within the recommended area. Also, a study of geothermal gradients from test holes in the Imperial Valley indicated that a thermal 
Table 5-16. Estimated energy potential, Imperial Valley Region KGRAs

\begin{tabular}{|c|c|c|c|c|}
\hline Location/KGRA & $\begin{array}{l}\text { Circular } 726 \\
\text { Designation }\end{array}$ & $\begin{array}{l}\text { Estimated } \\
\text { Reservoir } \\
\text { Temp. }{ }^{\circ} \mathrm{C}\end{array}$ & $\begin{array}{c}\text { Total } \\
\text { Reservoir } \\
\text { Heat } \\
\text { Content, } \\
\text { quads }\end{array}$ & $\begin{array}{l}\text { Electric } \\
\text { Energy } \\
\text { Potential, } \\
\text { MWe for } \\
30 \text { years }\end{array}$ \\
\hline Brawley & Brawley & 200 & 12 & 333 \\
\hline Dunes & Dunes & 135 & $\sim 2$ & 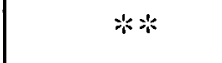 \\
\hline \multirow[t]{2}{*}{ East Mesa } & East Mesa & 180 & 22 & 487 \\
\hline & Border & 160 & $\sim 1$ & 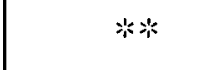 \\
\hline Ford Dry Lake & $*$ & - & - & - \\
\hline Glamis & Glamis (East) & 135 & $\sim 2$ & $* *$ \\
\hline Heber & Heber & 190 & 44 & 973 \\
\hline \multirow[t]{3}{*}{ Salton Sea } & Salton Sea & 340 & 83 & 2786 \\
\hline & Pilger Estate H.S. & & $\sim 1$ & 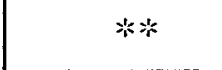 \\
\hline & & & 167 & 4579 \\
\hline
\end{tabular}

gradient in excess of $5.6^{\circ} \mathrm{C}$ per 30 meters ( 100 feet) of depth exists within the subject area. Based upon the above information and test wells drilled in the area the Brawley KGRA was established.

\section{Dunes KGRA}

The Dunes KGRA is in Imperial County in the southeastern part of the Imperial Valley, approximately 8 kilometers ( 5 miles) from the Mexican Border. It contains 7,680 acres.

The area was designated as a KGRA on the basis of geothermal indications. A study of geothermal gradients from test holes in the Imperial Valley indicated that a thermal gradient in excess of $5.6^{\circ} \mathrm{C}$ per 30 meters (100 feet) of depth exists within the subject area. Several wells have been drilled in the vicinity to test for oil and gas and for geothermal potential. Based upon the foregoing information the Dunes KGRA was established. 
East Mesa KGRA

The East Mesa KGRA, consisting of 38,365 acres in Imperial County, is in the southeastern part of the Imperial Valley, adjacent to the Mexican border. A study of temperature gradients in the area indicated a locally higher than normal temperature gradient below the area. This information, and some exploratory drilling, provided the basis for its designation as a KGRA.

$\underline{\text { Ford Dry Lake KGRA }}$

The Ford Dry Lake KGRA is located in Riverside County and contains 7,696 acres. The KGRA is approximately 29 kilometers (18 miles) west of Blythe, and 83.5 kilometers ( 52 miles) east and north of the Salton Sea in the Imperial Valley. Ford Dry Lake is located at the east end of the Chuckwalla Valley, and is one of four dry lakes occupying the valley.

Overlapping geothermal lease applications in the vicinity of Ford Dry Lake, Riverside County, filed in January 1974, indicated that competitive interest in the area exists. The Ford Dry Lake KGRA is based solely on competitve interest.

Glamis KGRA

The Glamis geothermal area, containing 25, 505 acres in Imperial County, is in the southeastern part of the Imperial Valley about 29 kilometers (18 miles) north of the Mexican border. This area was designated as a KGRA on the basis of geothermal indications. A study of geothermal gradients from test holes in the Imperial Valley indicates that a thermal gradient in excess of 4.4 to $5.6^{\circ} \mathrm{C}$ per 30 meters $(100 \mathrm{feet})$ of depth exists within the subject area. Several wells have been drilled in the vicinity to test for oil, gas, and geothermal potential. Based upon the foregoing information the Glamis KGRA was established.

$\underline{\text { Heber KGRA }}$

The Heber geothermal area of Imperial County contains 58, 568 acres. It is in the southern part of the Imperial Valley between El Centro and Calexico, 
adjacent to the Mexican border. This area was designated as a KGRA on the basis of geothermal indications. A study of geothermal gradients from test holes in the Imperial Valley indicated that a thermal gradient in excess of $5.6^{\circ} \mathrm{C}$ per 30 meters (100 feet) of depth exists within the subject area. Several wells have been drilled in the vicinity to test for oil, gas, and geothermal potential. Based upon the foregoing information the Heber KGRA was established.

\section{$\underline{\text { Salton Sea KGRA }}$}

The Salton Sea geothermal area is the largest KGRA in Imperial County, containing 95, 824 acres. It is located along the southern end of the Salton Sea near Niland in the Imperial Valley of Southern California.

Federal lands in the Salton Sea area were considered valuable for geothermal resource development and included in a proposed withdrawal effective March 21, 1967 by publication in the Federal Register, vol. 32, no. 57. In addition, information available indicates that two or more companies were exploring, applying for, or leasing lands for geothermal resources in the KGRA. Therefore, competitive interest in the area and the Salton Sea does exist. The KGRA has been so designated on the basis of geothermal indicia and competitive interest.

COUNTY PERSPECTIVES: THE IMPERIAL VALLEY REGION

The Imperial Valley Region is in an area which is receptive to growth in the residential and business sectors. Although it is apparently not eager to replicate the metropolitan patterns familiar in many urbanized centers, there is a willingness to entertain the idea of growth in a manner compatible with current business and social life. This has included a provision in the Imperial County General Plan of a containment of urban growth to existing urban locations and a strong commitment to the preservation of agricultural lands. County officials are hopeful that geothermal energy for electric and nonelectric applications will provide increased job opportunities and revenues in a manner consistent with current business activities. However, attention will not be 
diverted from environmental and social considerations for which local government is responsible. Special attention will be focused on favorable, and deleterious, effects on the agriculture industry. The region is enthusiastic about the development of its geothermal energy resources. This is in part evidenced by the large number of private and intergovernmental research and development activities which are taking place here. Provisions in county ordinances and in the General Plan have been made to as sure orderly and careful development in an expeditious manner.

\section{Procedural Requirements - Imperial County}

A proponent of geothermal activity in Imperial County is required to file for either an Exploratory Geothermal Well (Conditional Use) Permit or a Geothermal Development Project (Conditional Use) Permit with the County Planning Department (Table 5-17(a)). The application must be accompanied by proof of approval of the well program by the Division of Oil and Gas. The difference between the two permits is one of scope. The Exploratory Permit allows for no major construction on the site. If an operator is contemplating full development of a site, the Development Project Permit is the one for which he applies. The cost of each application is $\$ 25$.

At the time of application for either permit, an application is made for EIR preparation (Table 5-17(b)). The application fee is $\$ 15$ in addition to a fee for EIR preparation. There is a sliding fee scale, based upon the value of the project, of $\$ 50$ - 200. The EIR is prepared by the staff of the Planning Department. Every geothermal application requires an EIR in Imperial County. In the case of a Development Project Permit application, request for a designation of "geothermal" zone is made. Two such zoning designations currently exist at the Salton Sea KGRA. Conservatively speaking, 70-90 percent of the time to make a final decision on the application is in the preparation and review of the EIR. The EIR process has been lengthened by the requirement to submit EIRs to the State Clearinghouse, according to local officials. Imperial County has an Environmental Review Board comprised of County Department heads to review the EIR. 
Table 5-17. Use permit and EIR requirements, Imperial Valley Region - Imperial County

(a) Use permit requirements

\begin{tabular}{|c|c|c|c|c|c|}
\hline Use Permit & Activity Covered & Cost & $\begin{array}{l}\text { Decision- } \\
\text { Making Time }\end{array}$ & Reviewing Agencies & Special Provisions \\
\hline $\begin{array}{l}\text { Exploratory } \\
\text { Geothermal Well Permit, } \\
\text { County Ordinances } \\
\text { Section } 83226 a\end{array}$ & $\begin{array}{l}\text { Drilling up to } 610 \text { meters } \\
\text { ( } 2000 \text { feet) or to boiling } \\
\text { water with stipulations }\end{array}$ & $\$ 25$ & $\begin{array}{l}90-120 \text { days, } \\
\text { including EIR } \\
\text { preparation } \\
\text { and review }\end{array}$ & $\begin{array}{l}\text { - Planning Commission } \\
\text { - Planning Department } \\
\text { (after DOG approval) } \\
\text { - Public Works }\end{array}$ & $\begin{array}{l}\text { - Permit may be revoked if } \mathrm{n} n \\
\text { activity within } 6 \text { months } \\
\text { - Proof must be provided that } \\
\text { DOG has approved well program }\end{array}$ \\
\hline $\begin{array}{l}\text { Geothermal Development } \\
\text { Project Permit, } \\
\text { County Ordinances } \\
\text { Section } 83226 \text { a }\end{array}$ & $\begin{array}{l}\text { Reservoir development, } \\
\text { power plant construction }\end{array}$ & $\$ 25$ & & $\begin{array}{l}\text { - Planning Commission } \\
\text { - Planning Department } \\
\text { (after DOG approval } \\
\text { and filing with state's } \\
\text { Regional Water Quality } \\
\text { Control Board) } \\
\text { - Public Works }\end{array}$ & $\begin{array}{l}\text { - Permit may be revoked if no } \\
\text { activity within } 6 \text { months } \\
\text { - Proof must be provided that } \\
\text { DOG has approved well program }\end{array}$ \\
\hline
\end{tabular}

(b) EIR requirements

\begin{tabular}{|c|c|c|c|c|}
\hline EIR Cost & $\begin{array}{c}\text { Preparation } \\
\text { By }\end{array}$ & Reviewing Agencies & Decision-Making Time & Cornments \\
\hline $\begin{array}{l}\$ 15 \text { for } \\
\text { application } \\
\$ 50-200 \text { on } \\
\text { sliding scale } \\
\text { for preparation }\end{array}$ & $\begin{array}{l}\text { Planning } \\
\text { Department }\end{array}$ & $\begin{array}{l}\text { - Planning Commission } \\
\text { - Environmental Review Board } \\
\text { Planning Department } \\
\text { - Public Works } \\
\text { - Other County Agencies } \\
\text { - APCD } \\
\text { - State Clearinghouse } \\
\text { - Department of Fish and Game } \\
\text { - Water Quality Control Board } \\
\text { - Energy Resources Conservation } \\
\text { and Development Commission } \\
\text { - Other agencies as deemed } \\
\text { appropriate }\end{array}$ & $\begin{array}{l}90-120 \text { days inclusive } \\
\text { of conditional use } \\
\text { permit procedures }\end{array}$ & $\begin{array}{l}\text { - Required for geothermal energy } \\
\text { activity } \\
\text { - Generally little public response } \\
\text { - Sliding scale based upon value of } \\
\text { project }\end{array}$ \\
\hline
\end{tabular}




\section{Energy Ordinances - Imperial County}

Imperial County is the only county in our study which is preparing a geothermal element to the County General Plan (Table 5-18). The element is being prepared by the Planning Department of Imperial County based on research being performed by the University of California at Riverside and the California Institute of Technology. Although the Conservation Element has a specific section on the subject, the county apparently feels it wants a greater clarification of the issues and resource data involved with the energy source. There is an ordinance, promulgated by the Department of Public Works, governing current activities. This ordinance has been used as a prototype for counties elsewhere in the state. Major provisions of this ordinance require establishment of a land use zone specifically for geothermal energy development (a "G" $z$ one), an indemnity bond to meet any costs incurred by the county for the drilling activity, and insurance against liability in tort in a minimum amount of $\$ 1,000$, 000. Environmental protection requirements a re included in the ordinance.

\section{Relationships With Other Agencies - Imperial County}

The county perceives its relationships with state agencies as cooperative, although the processing of EIRs through the State Clearinghouse has lengthened its decision time. The Clearinghouse is estimated to increase the review period by almost twice, from 50 days to 90 days. The Division of Oil and Gas was praised for its relationship with the county.

The federal agency with which the county most often interacts is the Bureau of Land Management (BLM). Relations between BLM and the county were characterized as "fair".

This county is not unlike many others in the state in having clearly articulated concerns over energy development. In the Conservation Element of the General Plan, the county stresses that while national needs may at times supercede local wishes, the difficulties and needs, as a consequence of energy development, of local citizenery must not be ignored. The document 
Table 5-18. Energy regulations, Imperial Valley Region - Imperial County

\begin{tabular}{|c|c|c|}
\hline Energy Regulations & Date & Comments/Highlights \\
\hline $\begin{array}{l}\text { Terms, Conditions, Standards, } \\
\text { and Application Procedures For } \\
\text { Initial Geothermal Development, } \\
\text { County Ordinances Section } 83226 \text { a }\end{array}$ & May 1971 & $\begin{array}{l}\text { - Intent to encourage exploration and develop- } \\
\text { ment projects } \\
\text { - Intent to coordinate existing and anticipated } \\
\text { data } \\
\text { - Provision for a geothermal land use zone, } \\
\text { designated "G" zone } \\
\text { - Abandonment of a project for } 6 \text { months will } \\
\text { make permit null and void } \\
\text { - } \$ 50,000 \text { indemnity bond for each well drilled } \\
\text { or abandoned well re-entered, or } \$ 150,000 \\
\text { blanket bond for any number of wells drilled } \\
\text { or re-entered } \\
\text { - Insurance against liability-in-tort in a } \\
\text { minimum amount of } \$ 1,000,000\end{array}$ \\
\hline $\begin{array}{l}\text { Geothermal Energy Element, } \\
\text { County General Plan }\end{array}$ & $\begin{array}{l}\text { In preparation, } \\
\text { scheduled for } \\
\text { completion } \\
\text { Feb. } 1977\end{array}$ & $\begin{array}{l}\text { - Being prepared by the Planning Department } \\
\text { of Imperial County based on research by } \\
\text { University of California at Riverside and } \\
\text { California Institute of Technology }\end{array}$ \\
\hline $\begin{array}{l}\text { Conservation Element, } \\
\text { County General Plan }\end{array}$ & Dec. 1973 & $\begin{array}{l}\text { - Statement of local responsibility and interest } \\
\text { in energy planning, with emphasis on } \\
\text { (a) federal/state acknowledgment of local } \\
\text { jurisdiction, (b) consideration of localized } \\
\text { consequences of energy development, and } \\
\text { (c) water supply problems }\end{array}$ \\
\hline
\end{tabular}


requests that the state and federal governments be responsive to those needs in a timely and sensitive manner. Issues indentified by this document are:

1. Long and short term social, economic, and environmental effects resulting from development of geothermal resources intended to satisfy local and regional demand.

2. Authority of Imperial County to require adherence to its regulations and conditions on lands leased by the Federal Government is unclear.

3. Possibility of subsidence or seismic activity induced by extraction or reinjection of geothermal fluids, which may adversely affect agricultural activities.

The federal government maintains that there is no county jurisdiction on federally managed lands. Nonetheless, Imperial County, and others, have pressed claim to this jurisdiction. The two federal geothermal leaseholders, Republic Geothermal, Inc. and Magma Power, have honored the county's request to meet Conditional User Permit conditions. These companies have indicated that they feel it is unnecessary to do so. Nonetheless, in an apparent showing of good faith, they have applied for the appropriate county permits.

\section{The Future - Imperial County}

The future of geothermal energy development appears to be most promising in the Imperial Valley Region. There is open encouragement of research and development activities on the part of local authorities. Agricultural land holders hope for an increase in property values from the potential development. Some businesses hope to utilize the nonelectric potential to replace natural gas as a process heat source. Many residents currently utilize the resource for hot water. An augmented tax base, in the long term, is something for which the county also hopes. If the major concerns over subsidence and quality water supply can be successfully met, geothermal energy development will be viewed as a desirable and welcome energy source. 
The most intensive geothermal resource development activity outside The Geysers is taking place in or near the seven KGRAs in the Imperial Valley region. There is considerable activity in the area aimed primarily at exploration, drilling, and development to produce commercially viable hydrothermal wells for production of electricity. The bulk of the activities involve the Brawley, East Mesa, Heber, and Salton Sea KGRAs.

The most advanced effort is that of San Diego Gas and Electric Company (SDG\&E) working with Imperial Magma and New Albion Resources Company (an SDG\&E subsidiary) and with support from ERDA. At a site in the Salton Sea KGRA, SDG\&E is building a test loop facility which can lead to a $10 \mathrm{MW}$ power plant on-line by 1980.

At another site in the same area Southern California Edison, Phillips Petroleum, and Southern Pacific Land Company are working to develop technology to produce power and recover minerals. They are negotiating for ERDA support for a 20-month, $\$ 5$ million contract involving both power generation equipment and the design and analysis of energy conversion facilities. A successful program will lead to installation and operation of a $10 \mathrm{MW}$ pilot plant.

In February 1976, a meeting of the Imperial County Project Coordinating Council was held at El Centro to disseminate information among the may project directors and representatives of projects currently under way concerning geothe rmal matters in Imperial County. At the meeting it was noted that there was an acceleration of geothermal activity in the county. For example, one-half of the current projects were not under way a year ago. Also, in the last 6 months of 1975 there were 12 permit applications for geothermal wells, whereas in the first month of 1976 there were 29 such applications. In addition to the two organizations involved in power generation, there were five organizations doing drilling: Chevron Oil Company, Imperial Magma Company, Republic Geothermal, Union Oil Company, and the U.S. Bureau of Reclamation. Other organizations were engaged in resource engineering, studying geologic hazards, or developing hardware related to development of geothermal resource. 
In the Heber KGRA, Chevron Oil Company is performing hardware studies and resource assessment aimed at having a plant on line in the Heber area by early 1979. They a re working with Magma Power Company and New Albion Resource Company and have nine wells drilled. At present they a re involved in resource assessment, brine tests, and heat exchanger tests.

Geothermal resources on East Mesa KGRA are currently being explored by the Bureau of Reclamation. It is the purpose of the Bureau's research and development program to determine the feasibility of desalting mineralized geothermal fluids. The practicability of concurrent generation of electric power will also be investigated. The additional fresh water developed in the Imperial Valley can be used to augment the flows of the Colorado River system. Two test desalting plants, a multistage flash distillation unit, and a vertical tube evaporator distillation unit a re being used to evaluate various procedures for desalting geothermal fluids. Each unit was designed to produce from 20,000 to 50,000 gallons of distilled water per day. To date, five deep test wells more than 1,800 meters ( $5500 \mathrm{feet}$ ) in depth have been completed. Bottom hole temperatures of the deep holes range from 150 to $220^{\circ} \mathrm{C}$. Both Republic Geothermal and Magma Energy are also active in developing resources in the East Mesa KGRA. Republic drilled three wells on their federal leases in 1975 and reservoir evaluation is in process.

In the Brawley area Union Oil Company of California has drilled three successful wells and has filed notices to drill another ten. Testing will start afte $r$ an injection well is drilled and a field pipeline constructed. After testing, Union will decide how many of the proposed ten wells will actually be drilled. Depths are 1219 to 1524 meters $(4,000$ to 5,000 feet).

Activity has been limited at Dunes, Ford Dry Lake, and Glamis KGRAs. There has been no development activity at Ford Dry Lake, which is outside of the Imperial Valley, in Riverside County. At Glamis and Dunes, activity has been exploratory and limited to temperature-gradient studies conducted by the University of California at Riverside and a well drilled to 610 meters $(2,000$ feet) in Dunes KGRA by the Califcrnia Department of Water Resources with a maximum temperature of $103^{\circ} \mathrm{C}$. Table 5-19 summarizes the drilling operations in the Imperial Valley. 
Table 5-19. Wells drilled, Imperial Valley Region, 1971-75 (based on files of Division of Oil and Gas)

\begin{tabular}{|c|c|c|c|c|c|c|c|}
\hline Operator & Pre-1971 & 1971 & 1972 & 1973 & 1974 & 1975 & $\begin{array}{l}\text { Totals } \\
1971-75\end{array}$ \\
\hline Imperial Magma & 1 & & 5 & & 1 & & 6 \\
\hline Union Oil Co. of Calif. & & & & & & 3 & 3 \\
\hline Chevron Oil Co. & & & 1 & & 3 & 3 & 7 \\
\hline Magma Power Co. & & & 4 & 3 & & & 7 \\
\hline Republic Geothermal, Inc. & & & & & & 3 & 3 \\
\hline $\begin{array}{l}\text { U.S. Bureau of } \\
\text { Reclamation }\end{array}$ & & & 1 & 1 & 3 & & 5 \\
\hline $\begin{array}{l}\text { California Dept. of } \\
\text { Water Resources }\end{array}$ & & & 1 & & & & 1 \\
\hline Q. B. International & & & & 1 & & & 1 \\
\hline Others (Pre-1971). & 27 & & & & & & \\
\hline Totals & 28 & 0 & 12 & 5 & 7 & 10 & 33 \\
\hline
\end{tabular}


EASTERN SIERRA REGION

\section{REGIONAL OVERVIEW}

Five KGRAs are located in the Eastern Sierra Region: Bodie, Coso Hot Springs, Mono-Long Valley, Randsburg and Saline Valley (see Figs. 5-5, 5-6, and 5-7). Bodie and Mono-Long Valley KGRAs are in Mono County; Coso Hot Springs and Saline Valley KGRAs are in Inyo County; and Randsburg KGRA is in San Bernardino County. The region spreads from Bodie, north of Mono Lake, in a southeasterly direction to Randsburg in the northwest corner of San Bernardino County. The KGRAs lie close to U.S. Highway 395, which bounds the region on the west, between Bridgeport on the north and Johannesburg on the south. The California-Nevada stateline and Death Valley form the eastern border. The Mono-Long Valley KGRA is the largest of the KGRAs. Descriptions of the Bodie, Mono Lake, Long Valley, and Coso Hot Springs area follow.

$\underline{\text { Bodie }}$

The Bodie KGRA is in Bridgeport Valley, a structural basin about 10 kilometers ( 6 miles) wide and 12 kilometers ( 7.5 miles) long, at an elevation of 2,000 meters $(6,600$ feet). The valley is bounded by the Bodie Hills to the east and the east face of the Sierra Nevada to the west. U.S. Highway 395 traverses the valley from north to south, passing through the small town of Bridgeport, seat of Mono County. The valley floor, adjacent to the East Walker River, is used mainly for growing hay and for summer pasture for cattle. Hot springs occur in three places near the Bridgeport Valley: above the valley floor about 8 kilometers $(5$ miles) west of Bridgeport along Buckeye Creek, and in two locations on the edge of the Bodie Hills, 1 and 2 kilometers $(0.6$ and 1. 2 miles) south of Bridgeport.

\section{Mono Lake}

The Mono Lake basin has a barren, volcanic landscape. As a result, even grazing is limited. The major feature of the basin is Mono Lake, the remnant of a much larger Pleistocene lake. There is no present outlet from 
the lake and evaporation far exceeds inflow. Consequently, the lake volume is shrinking at a rate of 500 million cubic meters ( 18 billion cubic feet) per year. Salts carried into the lake are left behind as the water evaporates, and the concentration of total dissolved solids in the lake water now exceeds 60,000 ppm. The lake currently covers about 330 square kilometers (130 square miles) at an elevation of about 1,922 meters (6300 feet). The entire Mono Lake basin has a population of about 700 people, mostly concentrated in the town of Lee Vining near the juncture of U.S. Highway 395 and State Highway 120. The major source of income is from services and tourist facilities.

The Mono Basin land is principally national resource land under the administration of the Bureau of Land Management. Scattered tracts of privately-owned land, generally not comprising more than 2 square miles in a continuous tract, are found in the Mono Basin. The State of California owns the land beneath Mono Lake. The lake, a natural lake of 55, 000 acres, is in a closed basin with no outlet. Waters are highly mineralized and do not support fish life. Almost all of the former tributary flow to Mono Lake is diverted into the Los Angeles aqueduct system via Owens Valley.

The economy of the Mono Lake area is basically oriented to grazing. The only economic use of the area is harvesting brine shrimp from Mono Lake. Leevining the nearest town, has a recreation-oriented economy, is a gas and rest stop for travelers on U.S. Highway 395, and serves as a resupply point for people using Yosemite National Park. The economy is a narrow and fragile one - highly dependent upon the tourist trade.

Fig. 5-5. Bodie and Mono-Long Valley KGRAs Eastern Sierra Region (page 5-65)

Fig. 5-6. Saline Valley and Coso Hot Springs KGRAs Eastern Sierra Region (page 5-67)

Fig. 5-7. Randsburg KGRA - Eastern Sierra Region (page 5-69) 


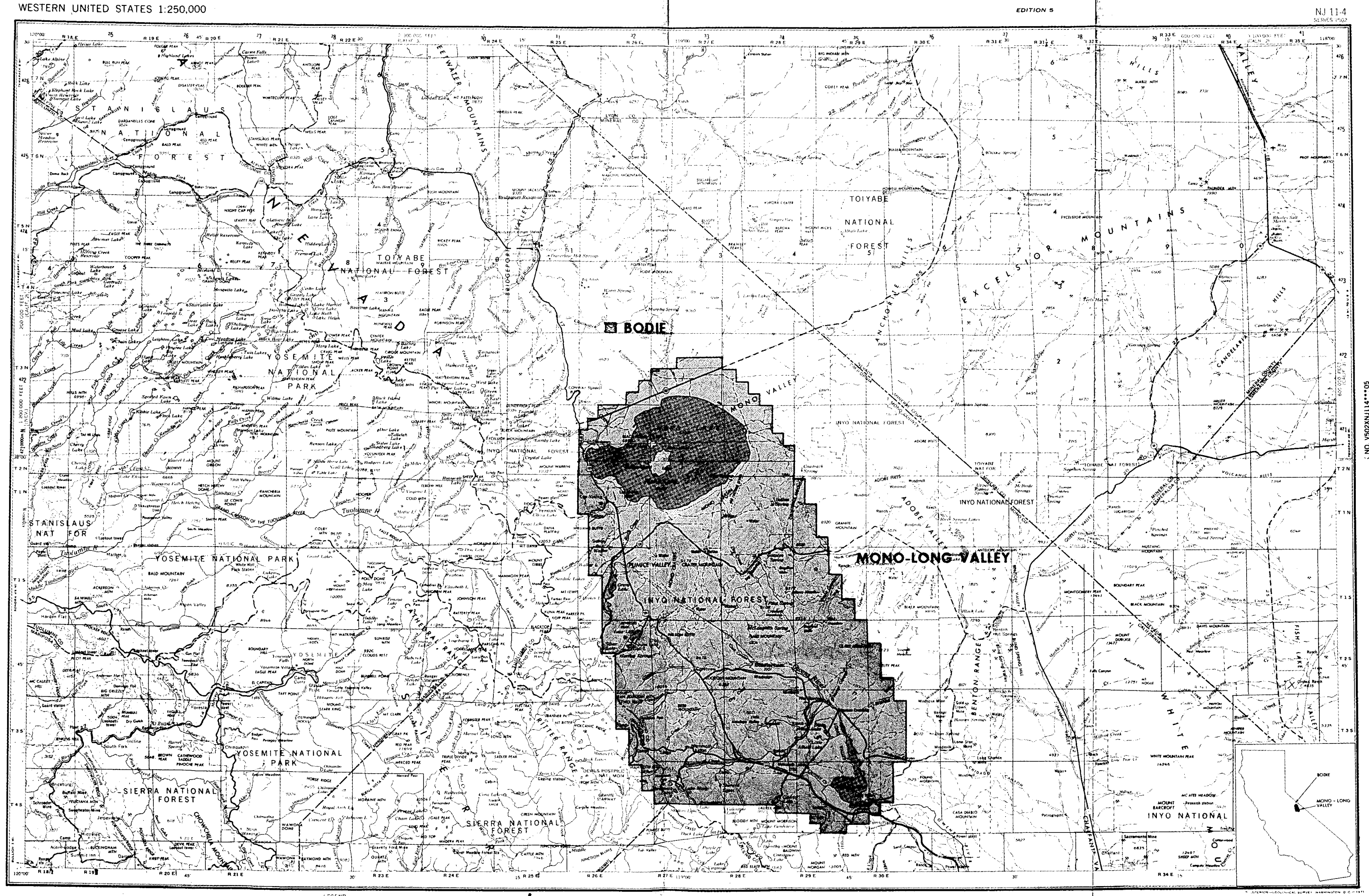

$\leq=5$

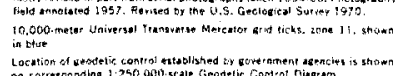

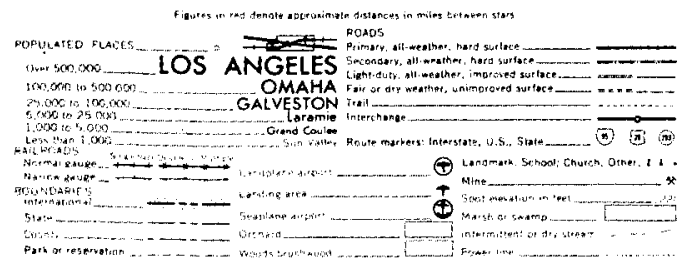

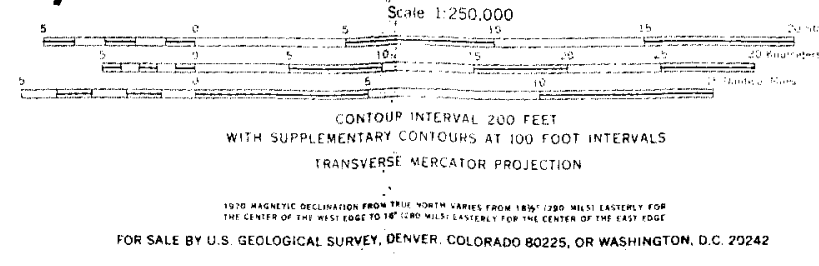

-

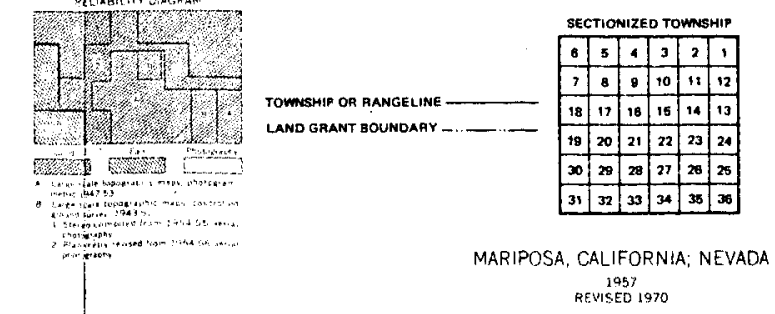





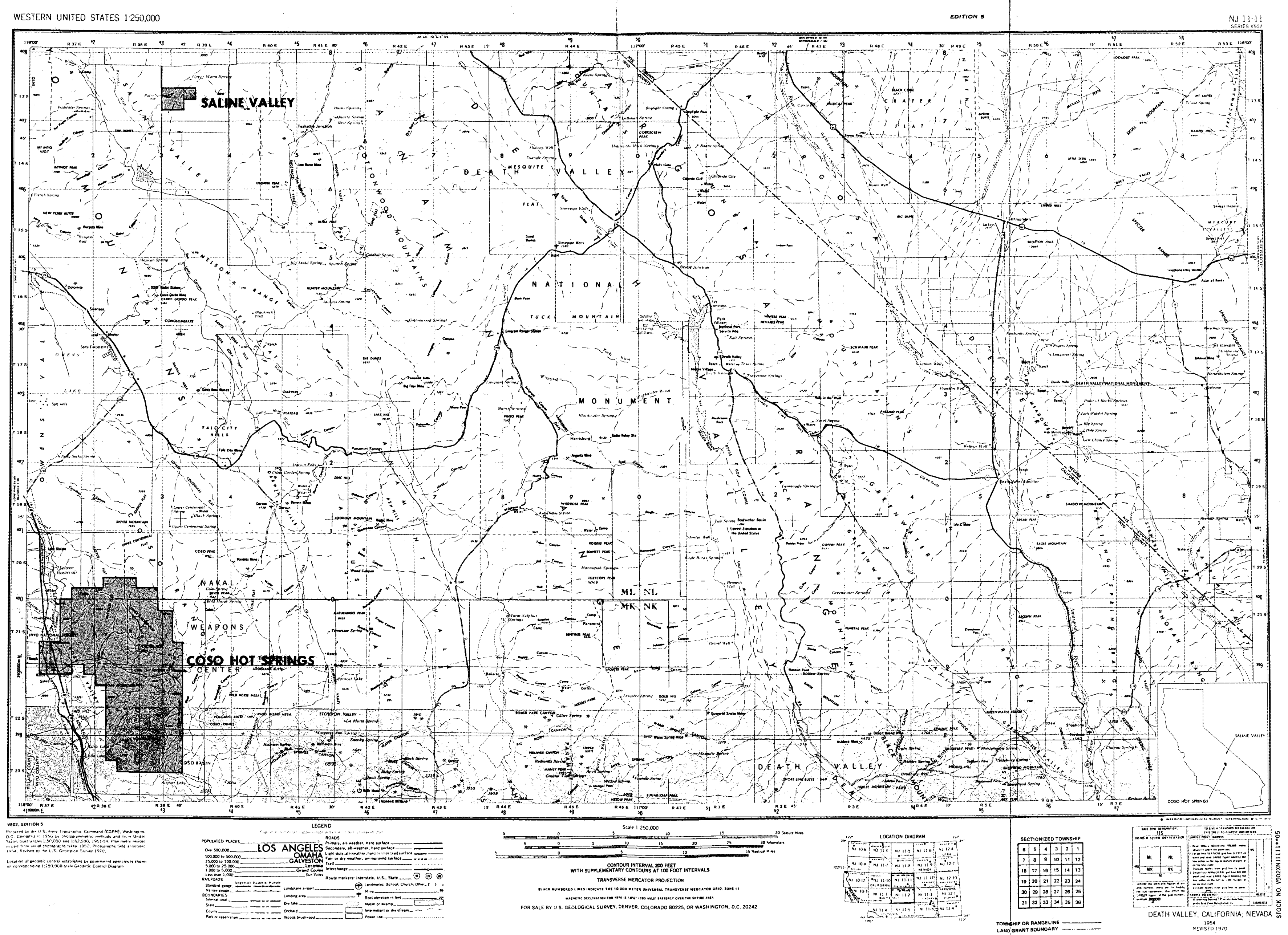





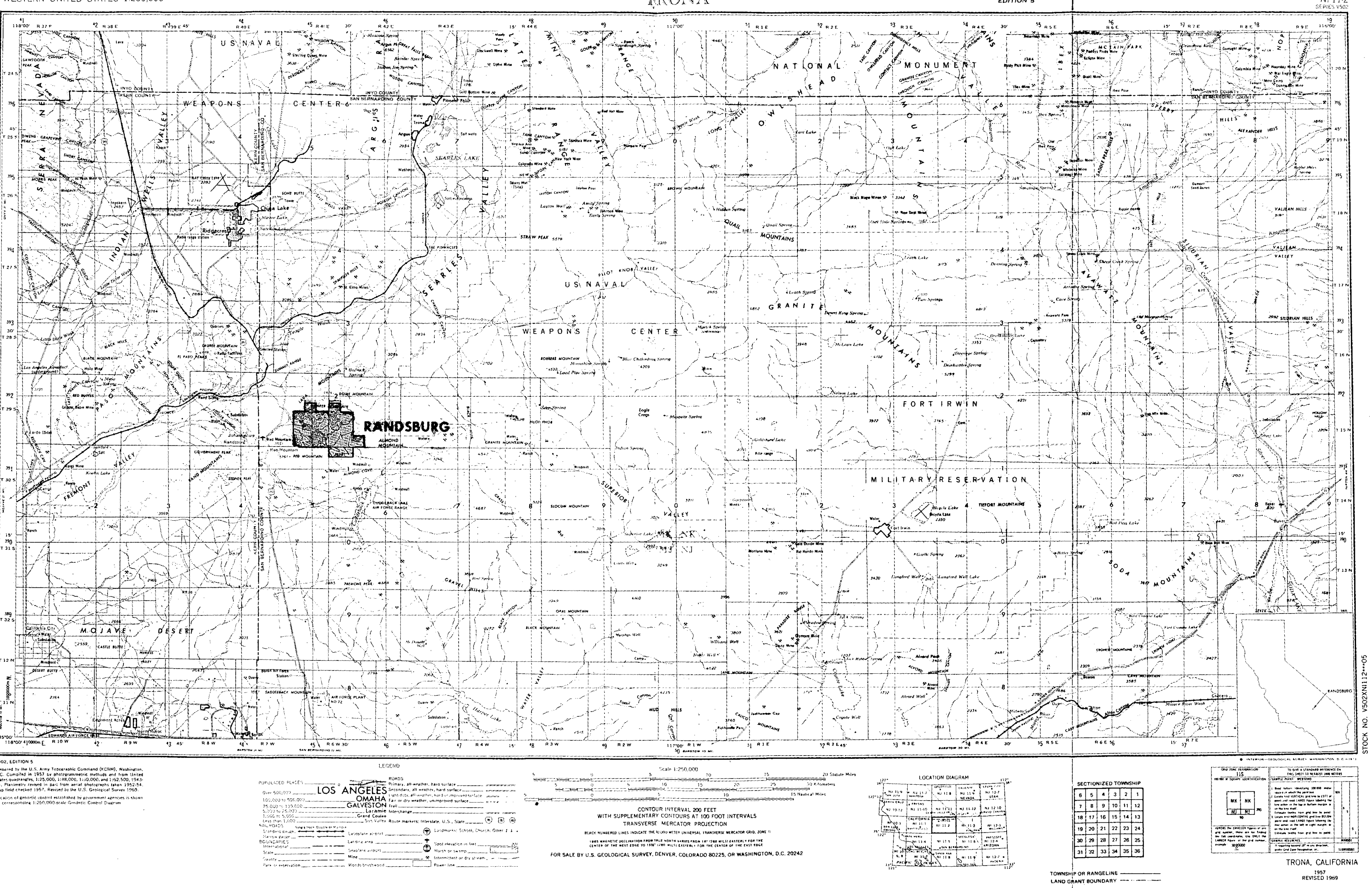



Present specific land use in the Mono Lake area consists of some roads, grazing permits, and a bird sanctuary on Negit Island. The Los Angeles City land is leased for sheep grazing and lessees must permit public hunting and fishing. No surface improvements or facilities are planned on the withdrawn national resource land or adjacent lands by the City of Los Angeles.

Recreational activities such as hunting, camping, and hiking exist throughout the Mono Basin. Nature study, riding, rock-hounding, and bottle hunting are other popular forms of recreation. Off-road vehicle use, including dune buggies, is moderate in the area. There are no established campgrounds within the Mono Lake area. However, because of the unique nature of tufa towers and pinnacle formations on the lake shore, several campsites have evolved.

$\underline{\text { Long Valley }}$

Long Valley is a 14 by 30 kilometer ( 8 by 19 mile) depression extending east from the Mammoth Lakes area of Mono County. The irregular floor of the valley ranges in elevation from 2,030 to 2, 400 meters (6700 to 7900 feet). A low mountain mass in the western half of the depression includes rhyolite domes reaching heights of 2,814 meters (9,200 feet). Mammoth Mountain, on the southwest rim of the depression, has an elevation of 3,316 meters (10,880 feet). Most of Long Valley's small population is clustered in the resort areas around Mammoth Lakes. The remaining land is utilized largely for cattle grazing. Other developments include a fish hatchery on Hot Creek, a gravel pit, and a kaolinite quarry.

Mammoth Lakes Village, adjacent to the geothermal area, consists of approximately 2,000 acres of private land. This area is completely surrounded by national forest land. Due to the rapid growth of the Mammoth area, pressures for varied land uses from local governments have been placed on the Forest Service owing to the limited amount of land in private ownership.

Most land owned by City of Los Angeles is leased for cattle grazing. Lessees are required to permit hunting and fishing by the general.public. The Forest Service in 1971 joined with Mono County and contracted with a group of land planners for an area land use plan for the Mammoth-Long Valley area. The Mammoth-Crowley Lake area is completely within this study area. The plan is being financed by Mono County, under a comprehensive planning grant 
from the Department of Housing and Urban Development, and by the Forest Service. To date, the Mono Plan has established an environmental base line and inventory, and has developed some land use alternatives for the area. County land use is primarily recreational. Potential geothermal land is zoned as "general purpose."

The principal economic enterprise in the Mammoth-Crowley Lake area is grazing of domestic livestock. In the vicinity of Mammoth and Lake Crowley, the valley lands are sub-irrigated and are used for livestock grazing. Some 4, 500 beef cattle and about 1,800 sheep graze on extensive pasture lands in this area and vicinity from late spring to early fall (Department of Water Resources Study of Long Valley). The mountain lands, owing to steep slopes, shallow soils, and dry climate, are used primarily for rangeland grazing and as wildife habitat. Extensive recreation activities take place throughout the Mammoth-Crowley area. The prime recreational activity is fishing on the large number of streams.

Perhaps the major land use could be considered to be municipal watershed, since most of the runoff feeds the Owens Valley Aqueduct System of the City of Los Angeles. Some 80 percent of the city supply is obtained from this system.

About 50 percent of the National Forest land within the Mammoth-Crowley Lake area is covered with commercial timber. The timbered portion lies on the westerly half of the area. Jeffrey pine is the dominant species with scattered white fir, lodgepole pine, single-leaf pinyon, and juniper.

In addition to commercial logging, commercial and free use fuel wood permits amounted to an additional 4 million board feet of timber harvested in fiscal year 1973 on the northern part of the forest. Most of the fuel wood is gathered in logged areas.

Wood is the major source of heating in the nearby communities because of the high cost of importing organic fuels and electricity. More than 1, 100 permits for wood were obtained in fiscal year 1973. There is a possibility that geothermal development could include providing heat energy for the local area as a substitute for wood. 
Grazing on the national forest portion of the area goes back many years and is well established. Good grazing land within the forested portions of this area is relatively scarce. Preferred areas are usually composed of small grass-covered valleys where ground water surfaces or rises to near the surface. These areas are most important to overall grazing management.

Hot Creek is a well known area for duck hunters and bird watchers. The warmer water flowing into Hot Creek provides an ice-free area during winter months, with relatively large amounts of food available.

Mammoth Mountain provides a ski area which is of national significance. Over 850,000 skiers visited Mammoth Mountain during the 1972-73 winter season. There are over 4,000 private homes and condominiums in the Mammoth area. Although the permanent population is only about 2,400, weekend and peak day use swells this population to approximately 18,000. Most of the private homes and condominiums are "second" recreational homes.

Coso Hot Springs Area

The Coso Hot Springs area is located in east-central California, approximately 480 kilometers (300 miles) north of Los Angeles and 56 kilometers (35 miles) north of China Lake. The area is in Inyo County and 51,760 acres have been classified as a KGRA.

The thermal area lies in the Mojave Desert east of the Sierra Nevada Range. Specifically, the thermal area is located in the southern part of the Coso Range, a region marked by young (Pleistocene and Holocene) volcanics;

i. e., cinder cones, domes and flows. Volcanism may have occurred as recently as 5,000 years ago.

The area occupies approximately 207 square kilometers (80 square miles), 168 square kilometers (65 square miles) of which lie within the boundaries of the Naval Weapons Center, China Lake. Accordingly, the principal portion of the area is controlled by the U.S. Navy and the Navy has announced plans to integrate the geothermal energy with other energy sources to form a "total energy community". These plans include a geothermal 
materials test facility and a $20 \mathrm{MWe}$ power plant;. The military reservation is not open to the general public.

Coso Hot Springs is a series of fumaroles and hot springs that occur along one of the northeast-trending faults. Hydrothermal alteration is common in the area. Recent analyses of the spring water indicates a total dissolved solids content of 1-2000 ppm and a silicate content of 2-300 ppm. The spring water is highly acidic and lacking in chloride. Maximum temperatures exceed $93^{\circ} \mathrm{C}$.

The terrain is typical of high desert areas. Water is in short supply with much of the indigeneous water being transported to Los Angeles via the Los Angeles Aqueduct which passes a few kilometers from the prospect. Owens Lake to the north is now dry. Ground water withdrawal for irrigation has not caused subsidence to date. Air quality is good, but has recently deteriorated because of flow from the Los Angeles Basin. Data on ambient noise is unavailable, but it is probably very low.

An environmental study of the area has been done by the Navy. Vegetation is of the desert scrub type. The fauna are typical for the desert including coyote, fox, rabbit, rat, squirrel, sparrow, lark, raven, and various species of lizards. Three rare/endangered species exist in the general region, the Owens Chub, Owens Pupfish, and the Mohave Ground Squirrel. There is no aquatic life in the prospect.

The area has been inhabited by the Piute Indians and many landmarks remain from the goldrush of the mid-1880s.

\section{KGRA DESCRIPTIONS AND RESOURCE ESTIMATES FOR THE EASTERN SIERRA REGION}

A brief tabulation of the location and basis for establishing the KGRA is given for each of the KGRAs in the region. An estimate of the extent of the resource and its potential is provided (Table 5-20). The KGRAs are presented alphabetically.

*Leonard, G. W.: Total Energy Community; The Military Engineer, No. 434. 
Table 5-20. Estimated energy potential, Eastern Sierra Region KGRAs

\begin{tabular}{|c|c|c|c|c|}
\hline Location/KGRA & $\begin{array}{l}\text { Circular } 726 \\
\text { Designation }\end{array}$ & $\begin{array}{l}\text { Estimated } \\
\text { Reservoir } \\
\text { Temp. }{ }^{\circ} \mathrm{C}\end{array}$ & $\begin{array}{c}\text { Total } \\
\text { Reservoir } \\
\text { Heat } \\
\text { Content, } \\
\text { quads }\end{array}$ & $\begin{array}{c}\text { Electric } \\
\text { Energy } \\
\text { Potential, } \\
\text { MW for } \\
30 \text { years }\end{array}$ \\
\hline Bodie & $*$ & - & - & - \\
\hline Coso Hot Springs & Coso Hot Spg. & 220 & 163 & 4,533 \\
\hline \multirow[t]{4}{*}{ Mono Long Valley } & Long Valley & 220 & 218 & 6,083 \\
\hline & Near Black Pt. & 125 & 1 & 氺况 \\
\hline & Paoha Island & 125 & 1 & $* *$ \\
\hline & Red's Meadow & 165 & 1 & 㳻决 \\
\hline Randsburg & Randsburg & 125 & 2 & $* * *$ \\
\hline \multirow[t]{2}{*}{ Saline Valley } & $*$ & - & - & - \\
\hline & & & 386 & 10,616 \\
\hline $\begin{array}{l}\text { * No data availab } \\
\text { **Indicated tempe } \\
\text { suitable for nor }\end{array}$ & $\begin{array}{l}\text { re too low for c } \\
\text { ric applications }\end{array}$ & ial powe & gener & \\
\hline
\end{tabular}

\section{Bodie KGRA}

The 640-acre Bodie KGRA is located in Mono County, approximately 9.6 kilometers (6 miles) southwest of Bodie, California. Mono Lake is 16. 4 kilometers ( 10 miles) to the south.

Overlapping geothermal lease applications in the vicinity of Bodie, filed during April 1974, indicated that competitive interest in the area existed. The Bodie KGRA is based solely on competitive interest.

\section{Coso Hot Springs KGRA}

The Coso Hot Springs KGRA is in Inyo County at the north end of Indian Wells Valley, east of the Sierra Nevada in east-central California, about 322 kilometers (200 miles) north of Los Angeles. The KGRA contains 51,760 acres. 
Shortly after the initial list of lands valuable for geothermal resource development was published in the Federal Register (March 1967), this area was determined to be potentially valuable for geothermal resource development. In 1967 the U.S. Navy and California Division of Mines and Geology drilled a shallow well 114 meters ( 375 feet) deep which produced steam and water at $142^{\circ} \mathrm{C}$. Surface manifestations in the area and geophysical investigations also indicate geothermal potential. Based on the above information the Coso Hot Springs KGRA was established.

\section{Mono-Long Valley KGRA}

The Mono-Long Valley KGRA is the largest in California. It contains 460, 256 acres, mostly in Mono County. A small portion of the southeastern corner of the KGRA extends into Madera County. The area is in east-central California about 80 kilometers (50 miles) north of Bishop and about 322 kilometers (200 miles) south of Reno, Nevada.

Federal lands in the Mono-Long Valley area were considcred valuable - for geothermal resource development and included in a proposed withdrawal effective March 21, 1967, by publication in the Federal Register, Vol. 32, No. 57. There are several fumaroles and many hot spring groups in the Mono-Long Valley geothermal arca with water temperatures up to boiling. In addition, there are numerous localities where hydrothermal alteration is evident and many areas where the heat flow is so high that snow does not stay on the ground.

An acromagnetic survey of the region disclosed a magnetic anomaly indicating a mass of dense magnetic material beneath the surface. This may represent buried volcanic and intrusive rock which is the heat source for the various thermal springs in Long Valley.

Various organizations have shown interest in the area by exploring, applying for, or leasing lands for gcothermal resources in the KGRA. Several wells were drilled at Casa Diablo Hot Springs by Magma Power Company and Endogenous Power Company from 1959 to 1962 . The deepest hole was about 365 meters (1,200 feet) deep but did not adequately test the geothermal potential of the area. Consequently, competitive interest does exist regarding the lands in the KGRA. 
Based on the above geothermal manifestations and existing competitive interest, the area was designated as a KGRA.

Randsburg KGRA

The Randsburg KGRA is 4.83 kilometers ( 3 miles) east of the town of Johannesburg, in San Bernardino County, and about 29 kilometers (18 miles) south of the town of Ridgecrest in Kern County. It contains 12,880 acres.

Overlapping geothermal lease applications in the vicinity of Randsburg, San Bernardino County KGRA indicated that competitive interest in the area exists. The Randsburg KGRA is based solely on competitive interest.

\section{Saline Valley KGRA}

The Saline Valley KGRA in Inyo County contains 3200 acres. It is located approximately 29 kilometers (18 miles) northeast of Owens Lake. The KGRA. is located in a side valley at the northeast corner of Saline Valley.

Overlapping geothermal lease applications in the vicinity of Saline Valley, Inyo County, indicate that competitive interest in the area exists. The Saline Valley KGRA is based solely on competitive interest. However, a number of hot springs are located in the side valley to Saline Valley where the proposed KGRA is located. The water of the springs is of low salt content and quite potable. Water temperature is in the vicinity of $55^{\circ}-65^{\circ} \mathrm{C}$.

\section{COUNTY PERSPECTIVES - INYO AND MONO COUNTIES: THE EASTERN SIERRA REGION}

Both Inyo and Mono Counties are favorably disposed towards geothermal energy development. Nonetheless, their approaches to the planning for such development and their perspectives are distinctly in contrast. Both counties are heavily dependent upon tourism. Agriculture is also part of the local economy, particularly cattle and sheep. They have relatively small populations, mostly clustered in modestly sized communities. The largest towns for each county are Bishop $(\sim 13,000$, of which only 3,000 live in the incorporated city) and Mammoth Lakes $(\sim 3,500)$. Both counties have a significant 
portion of lands within their jurisdictional boundaries managed by the U.S. Forest Service and BLM. Inyo County is approximately 94 percent managed primarily by the federal government (a small percentage is state-owned land); Mono County has 81 percent of its land managed primarily by the federal government. In toto, within the Mono-Long Valley KGRA, about 90 percent of the land is federally managed, and about 10 percent is privately owned.

Most of the work force in Inyo County is employed by one of the four levels of government. There is a significant retirement community, though not to the proportion found in Mono County, where such residents number about one-half of the population. Inyo County residents have been characterized as environmentally sensitive, while those in Mono are generally split equally on such issues between those in the work force and those who are retired. Those who are working tend to favor the emergence of new business opportunities. Retired residents, who often have moved from major metropolitan areas to the more peaceful Eastern Sierra counties, favor strong environmental values and no new growth. Nonetheless, there has been strong public comment (from within and without the county) over proposed geothermal drilling on grounds of aesthetics, wildlife protection, and potential adverse economics on commercial spas.

The approach to county jurisdictional authority is one of marked contrast, too. Inyo County is strongly committed to forcing compliance with local regulations on federally managed lands. The county has asserted that local Conditional Use Permits must be obtained prior to commencing any activity. Getty Oil voluntarily complied with the county's request even though it maintained that the permit was superfluous. The federal agencies assert that neither state nor local authorities have any jurisdiction over lands which they administer. On the other hand, Mono County has shown a decided interest in remaining completely exterior to the federal process, except as a review agency. It is the county's perspective that the county unjustly pays severe penalties when it is involved with state or federal agencies and litigation ensues. The higher levels of government pass on heavy and burdensome decision-making costs. Rather than being named "lead agency" on other than private lands over which it has jurisdiction, the county favors the role of reviewing agency 
on behalf of private property owners. Intervention will occur only when an adverse impact is in evidence on property owners and citizens of the county.

Mono County officials tend to have more working knowledge about geothermal energy than those in. Inyo County. Both counties seem receptive to the development of geothermal resources, particularly if it can displace other heating fuels. Southern California Edison has identified this as a desirable use in the Mammoth Lakes area.

$\underline{\text { Procedural Requirements - Inyo and Mono Counties }}$

Both counties require application for Conditional Use Permits from their respective planning departments (Table 5-2l(a)). Decisions by the planning directors are presented to the Planning Commissions for consideration. If a negative declaration is decided upon, both counties require approximately 60 days to make a final decision. If an EIR is required (Table 5-21(b)), Mono County estimates an additional 6-8 months to reach a final decision on the Use Permit; Inyo County estimates only 2-3 months from the receipt of an acceptable draft EIR. It should be noted that because of the newness of the Inyo Planning Department (about 6 months) there has been little experience with EIRs. Mono County provides the option to the applicant to either directly contract for the EIR preparation or have the county arrange for it. The latter mode is more time-consuming. The Inyo County Planning Department is responsible for final EIR preparation, but has the applicant submit the requested draft EIR, as provided for by the State's EIR guidelines.

\section{Energy Ordinances - Inyo and Mono Counties}

Inyo and Mono Counties also differ with respect to governance of energy activities ( Table 5-22). Inyo has a strong ordinance based upon the ordinance in Imperial County, with some modification. Two modifications of note are (1) the requirement of a $\$ 50,000$ indemnity bond for each well regardless of number of wells and (2) the provision for a hot springs protection program. 
Table 5-21. Use permit and EIR requirements, Eastern Sierra Region - Inyo and Mono Counties

(a) Use permit requirements

\begin{tabular}{|c|c|c|c|c|c|c|}
\hline County & Use Permit & Activity Covered & Cost & $\begin{array}{c}\text { Decision-Making } \\
\text { Time }\end{array}$ & Reviewing Agencies & Special Provisions \\
\hline Mono & $\begin{array}{l}\text { Conditional use } \\
\text { permit, County } \\
\text { Ordinance } \# 379\end{array}$ & $\begin{array}{l}\text { Shallow temperature } \\
\text { gradient testing through } \\
\text { utilization, as specified }\end{array}$ & $\$ 15$ & $\begin{array}{l}\text { Minimum } 2 \text { weeks; } \\
\text { usually } 45-60 \text { days } \\
\text { without EIR }\end{array}$ & $\begin{array}{l}\text { - Planning Commission } \\
\text { - Planning Department }\end{array}$ & $\begin{array}{l}\text { Must begin activity } \\
\text { within } 6 \text { months }\end{array}$ \\
\hline $\begin{array}{l}\text { Inyo } \\
\text { a. }\end{array}$ & $\begin{array}{l}\text { Conditional use } \\
\text { permit }\end{array}$ & $\begin{array}{l}\text { Shallow temperature } \\
\text { gradient testing through } \\
\text { utilization, as specified }\end{array}$ & $\begin{array}{l}\$ 35 \\
\$ 50 \text { with EIR } \\
\text { application }\end{array}$ & $\begin{array}{l}60 \text { days without } \\
\text { EIR preparation } \\
90 \text { days with EIR }\end{array}$ & $\begin{array}{l}\text { - Planning Commission } \\
\text { - Planning Department } \\
\text { - Public Works } \\
\text { - Other county agencies }\end{array}$ & \\
\hline
\end{tabular}

(b) EIR requirements

\begin{tabular}{|c|c|c|c|c|c|}
\hline County & EIR Cost & $\begin{array}{c}\text { Preparatior } \\
\text { By }\end{array}$ & Reviewing Agencies & Decision-Making Time & Comments \\
\hline Mono & $\begin{array}{l}\text { Determined } \\
\text { by contractor }\end{array}$ & $\begin{array}{l}\text { Contractor } \\
\text { either through } \\
\text { county or } \\
\text { applicant }\end{array}$ & $\begin{array}{l}\text { - Planning Commission } \\
\text { - Planning Department } \\
\text { - Other county agencies } \\
\text { - State Clea ringhouse }\end{array}$ & $\begin{array}{l}\text { l year from application } \\
\text { to final action, if county } \\
\text { contracts. } \\
6-8 \text { months if applicant } \\
\text { arranges for preparation. }\end{array}$ & $\begin{array}{l}\text { Probably not necessary for shallow } \\
\text { temperature gradient testing - } \\
\text { "Exploratory deep wells usually } \\
\text { require finding of significant Impact" }\end{array}$ \\
\hline Inyo & $\begin{array}{l}\$ 50 \text { for } \\
\text { application } \\
\text { and evaluation }\end{array}$ & $\begin{array}{l}\text { Planning } \\
\text { Department }\end{array}$ & $\begin{array}{l}\text { - Planning Commission } \\
\text { - Planning Department } \\
\text { - Public Works } \\
\text { - State Clearinghouse }\end{array}$ & $\begin{array}{l}15-60 \text { days for Negative } \\
\text { Declaration or } 60-90 \text { days } \\
\text { after receipt of an } \\
\text { acceptable EIR }\end{array}$ & Little experience with EIR preparation \\
\hline
\end{tabular}


Table 5-22. Energy regulations, Eastern Sierra Region - Inyo and Mono Counties

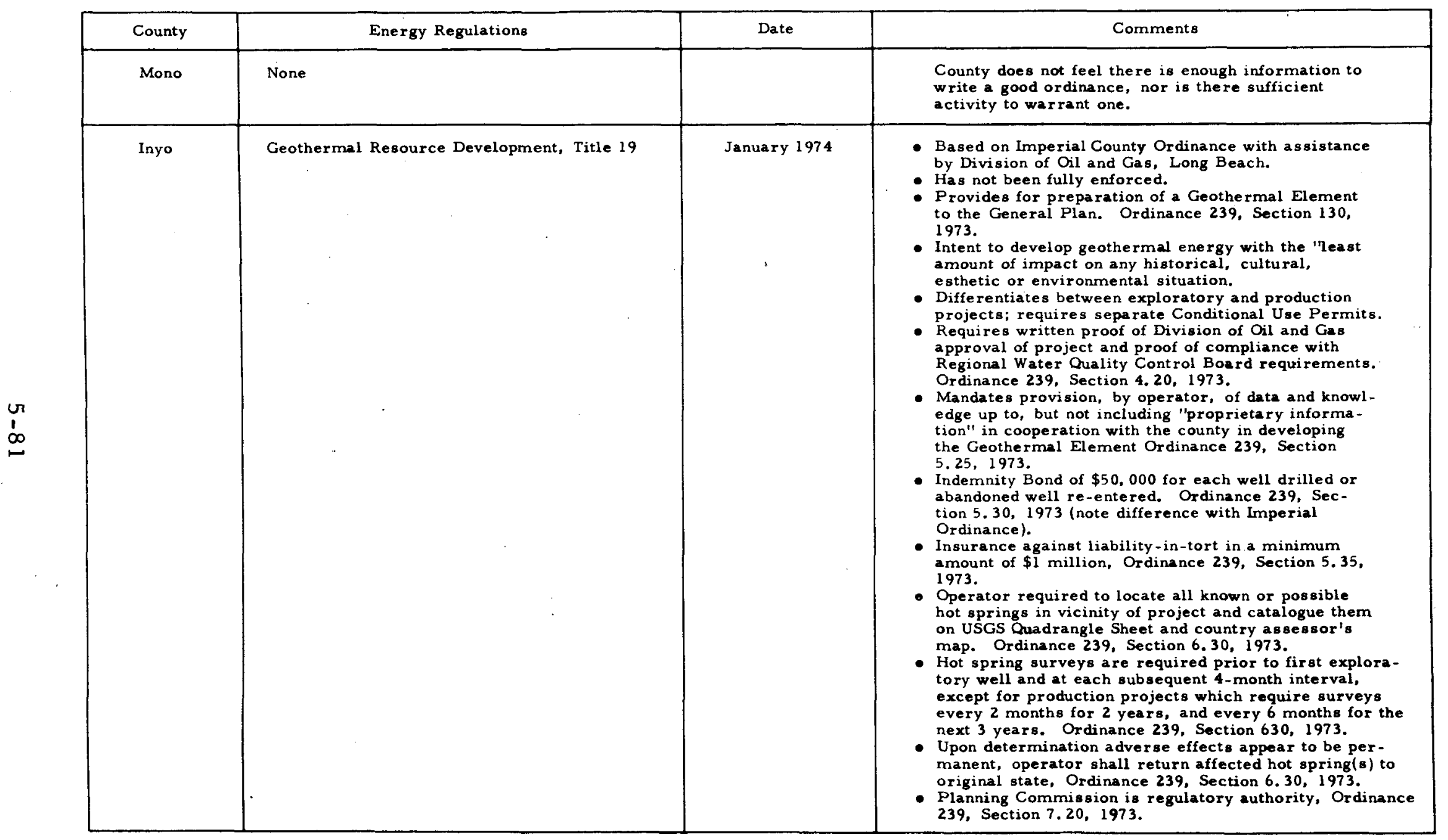


Other provisions are generally identical to the Imperial ordinance. Although this ordinance appears to be a rigorous one, it is important to note that the county has not enforced the provisions. In a recent review of the ordinance, the Planning Commission elected to maintain it in the current form until there had been some experience with it. Revision of the ordinance would require staff resources for which there are other priorities. Given the present lack of geothermal activity, there may be no press to urge further reconsideration, particularly if the enforcement is so lax. In addition, the development of the Geothermal Element to the General Plan provided for in the ordinance is not currently being considered. Revision of county EIR procedures and fee schedules is a major concern of the Planning Director.

Mono County has no special energy ordinances. Currently, ịt is felt that there is insufficient information to write one. Although there is community concern and operator interest in developing county geothermal resources, it is the position of the county that it can meet these concerns with statutes already on the books. In fact, it is believed that writing an ordinance at the current stage of development would be potentially detrimental.

Interagency Relationships - Inyo and Mono Counties

Inyo and Mono County officials acknowledged good working relationships with the local federal agency offices. The Inyo National Forest Service has been the promulgator of a strong public education and involvement program aimed at educating about geothermal energy and listening to the public views. In addition to presentation of listening sessions, there have been field trips and much media coverage. These public workshops were well attended. The California Division of Oil and Gas was credited with having a particularly good relationship with Mono County officials. Inyo and Mono Counties are participating informally in discussions with other county officials in an attempt to eliminate differing sets of geothermal energy standards between counties. 
The Future - Inyo and Mono Counties

There is likely to be greater attention paid to these counties in the future. Over the past 2-3 years major geothermal research activities have been undertaken here. It is a reasonable expectation that federal and state energy programs will want to pursue the development of this geothermal energy resource. Both counties have evidenced willingness to encourage such endeavors. Under proper guidance, and involvement of local persons, there is good reason to believe that this resource can be cooperatively developed.

GEOTHERMAL DEVELOPMENT

STATUS IN THE EASTERN SIERRA REGION

The Eastern Sierra region contains the KGRA with the greatest acreage in California: Mono-Long Valley. Bodie, Coso Hot Springs, Saline Valley, and Randsburg KGRAs are also in this region. Most activity has occurred in the Mono-Long Valley area, with some additional activity at Coso Hot Springs. There has been no recent activity at Bodie, Saline Valley, or Randsburg although, in 1960, Magmà Power Company drilled a shallow well (235 meters (772 feet)) near the Randsburg steam well (drilled in 1920) and measured a maximum temperature of $166^{\circ} \mathrm{C}$.

Magma Energy Co. drilled 10 shallow wells near Casa Diablo Hot Springs in the Mono-Long Valley area in the late 1950s and early 1960s. Two wells were drilled for the USGS near Mono Lake in 1971. The USGS has conducted an intensive geotechnical investigation in the area. Temperature gradient testing has been going on for about two to three years. The USGS Geologic Division has been drilling and taking core samples, and the Water Resource Division drilled a well in the summer of 1975. The area has been used as a research opportunity for USGS to try new techniques. Thus, in some respects, it has been extensively explored.

Recent activity in the Mono-Long Valley KGRA has been mostly limited to lease sales. Most of the land which has a potential for the development of geothermal energy in the Long Valley area is managed by the U.S. Forest Service. The decision to lease these lands is being held in abeyance pending 
the completion of an EIS for the area. The Forest Service is concerned about getting a strong degree of public involvement in the writing of the EIS because the issue of geothermal development in this area is controversial. There are existing leases of Bureau of Land Management land in the a rea which date back to 1973. At that time the land was leased in three "blocks".

Blocks 1 and 2 are under litigation and have been since 1973. The litigation is directly tied to the definition of the Geothermal Resource. The Geothermal Steam Act of 1970 provides for "grandfather rights". Block 1 bidders were Chevron Oil Company and Geothermal Resources International; they are presently in contention over grandfather rights. Similarly, on Block 2, Geothermal Resources International is in contention with Getty Oil Company over grandfather rights. Block 3 was leased by Republic Geothermal in conjunction with the City of Burbank. Republic has done some exploration on this lease. A number of shallow temperature gradient holes have been drilled. Temperatures have been about $43^{\circ} \mathrm{C}$ at 305 meters ( 1000 feet) except for one that was $90^{\circ} \mathrm{C}$ at 30 meters (100 feet). A deep well of about 2740 meters (9,000 feet) is planned for 1976.

Currently there are about three to four thousand acres that BLM is proposing to lease in this vicinity. Joined with the Forest Service land, it totals approximately 26,000 acres. BLM is cooperating in an EIS preparation with the U.S. Forest Service. The first lease of land by BLM was offered in January 1974 and it is estimated that it will take 2-1/2 years or more from the lease date until deep holes will be drilled.

Southern California Edison has indicated an interest in the geothermal resources of the Mono-Long Valley area as was discussed in Section III.

Further south, in the Coso Hot Springs KGRA, about 80 percent of the land is controlled by the U.S. Navy. All recent activity on the KGRA has been initiated by the Navy. Plans include a geothermal materials test facility and a $20 \mathrm{MW}$ power plant. The area is now the scene of a geophysical investigation program being conducted by the University of Texas at Dallas. This investigation involves heat flow and micro-earthquake studies. No heat flow results have been made available to date. Presently no lease sales are scheduled within the KGRA. 


\section{NOR THEAST REGION}

\section{REGIONAL OVERVIEW}

The Northeast Region, located in the northeast corner of the state, contains five KGRAs scattered through a five county region. They extend from Glass Mountain KGRA in east central Siskiyou County and Lake City-Surprise Valley KGRA in east central Modoc County, in the northern portion of the region; through Lassen KGRA, straddling the Tehama-Plumas county line, and Wendel Amedee KGRA on Honey Lake in Lassen County; south to Beckwourth Peak.KGRA southeast of Portola on State Highway 70 in Plumas County. The region is roughly bounded by the California-Oregon state line on the north, the Nevada state line on the east, Interstate 5 on the west and State Highway 70 on the south. The region and KGRAs are shown in Figs. 5-8, 5-9, and 5-10.

Lake City-Surprise Valley and Glass Mountain Area

Surprise Valley trends north-south and is approximately 88 kilometers (55 miles) long and an average of 13 kilometers ( 8 miles) wide. Geologically, it is down-dropped fault block (graben) with up-lifted fault blocks (horsts) forming the mountain ranges to the east and west. The valley has internal drainage and contains three large lakes - Upper, Middle, and Lower Alkali Lakes. The lakes are extremely saline, seldom more than 1.5 meters ( 5 feet) deep, and often are dry in the summer. State Highway 299 goes through Cedar Pass, providing easy access from Alturas to Cedarville, Surprise Valley's largest town. The remainder of the valley's small population is scattered in three village and on ranches along the western edge. Surprise Valley has a climate typical of high elevation deserts.

Numerous small creeks issuing from the Warner Mountains supply irrigation water for Surprise Valley. Because of generally low yields from wells, ground water is used mainly for stock-watering or domestic water supply. Wells drilled near thermal springs may produce water with excessive concentration of sodium, boron, fluoride, or arsenic. 
Several mudpots and hot springs about 3 kilometers ( 2 miles) north of Lake City mark the site of a spectacular mud volcano eruption in March 1951. Prior to the eruption, the springs were inconspicuous and their temperatures and flow rates were not definitely known. The eruption began without warning at about 11:30 p.m. on March 1, 1951, and continued with decreasing vigor for about 4 days. Initially, large chunks of mud were thrown several hundred feet in the air, and strong winds carried frozen mud pellets up to 7 kilometers (4 miles) from the site. The area has been quiet since then, and the springs maintain fairly constant temperatures ranging from 48 to $97^{\circ} \mathrm{C}$.

The landscape within Surprise Valley is relatively flat and unobstructed. There are many irrigated farms. The area is not of high aesthetic quality; much of the natural environment has been altered by agricultural activities.

Water is a limited natural resource in Modoc County. Three lakes exist in Surprise Valley; these are alkaline and of poor quality. Wildlife and waterfowl use these extensively. Air quality is very good.

An Environmental Impact Report pertaining to geothermal exploration is available.

Vegetation is of the northern desert scrub type incluaing sagebrush, bitterbush, juniper, and various grasses. Vegetation in Surprise Valley is low and sparse. Wildlife includes deer, antelope, rabbit and birds (dove,

Fig. 5-8. Lake City-Surprise Valley and Glass Mountain KGRAs Northeast Region (page 5-87)

Fig. 5-9. Lassen and Wendel-Amedee KGRAs - Northeast Region (page 5-89)

Fig. 5-10. Beckwourth Peak KGRA - Northeast Region (page 5-91) 

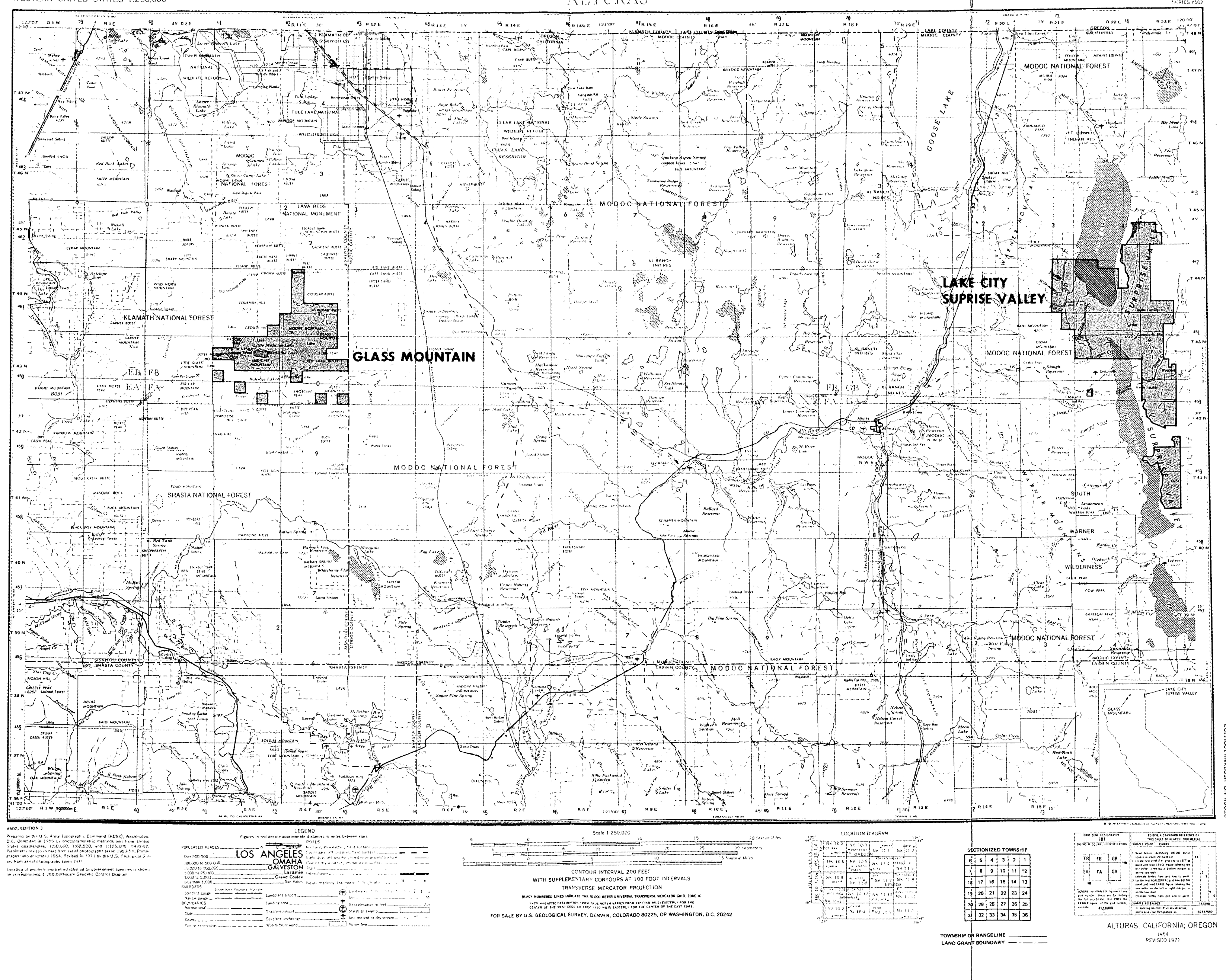


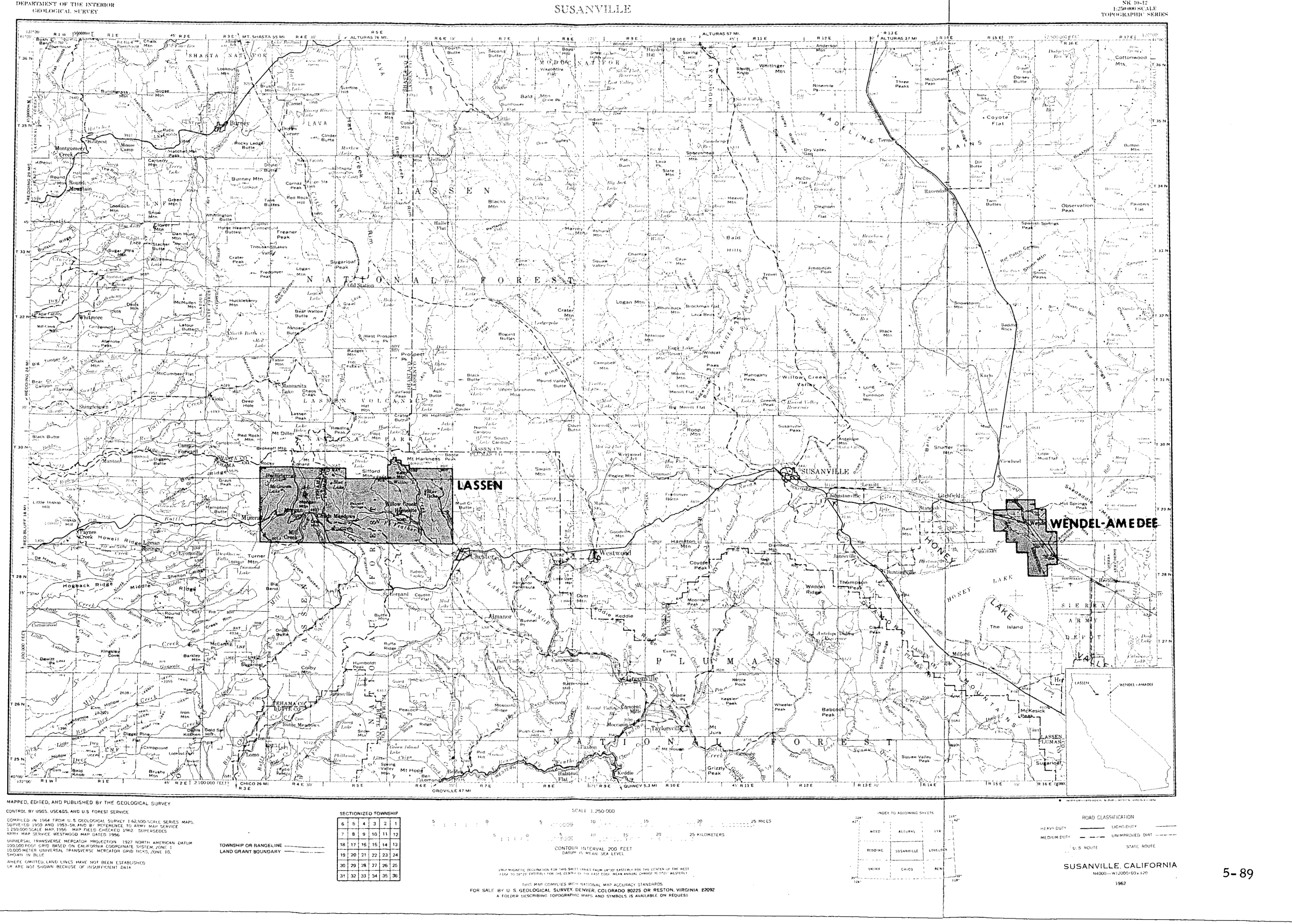





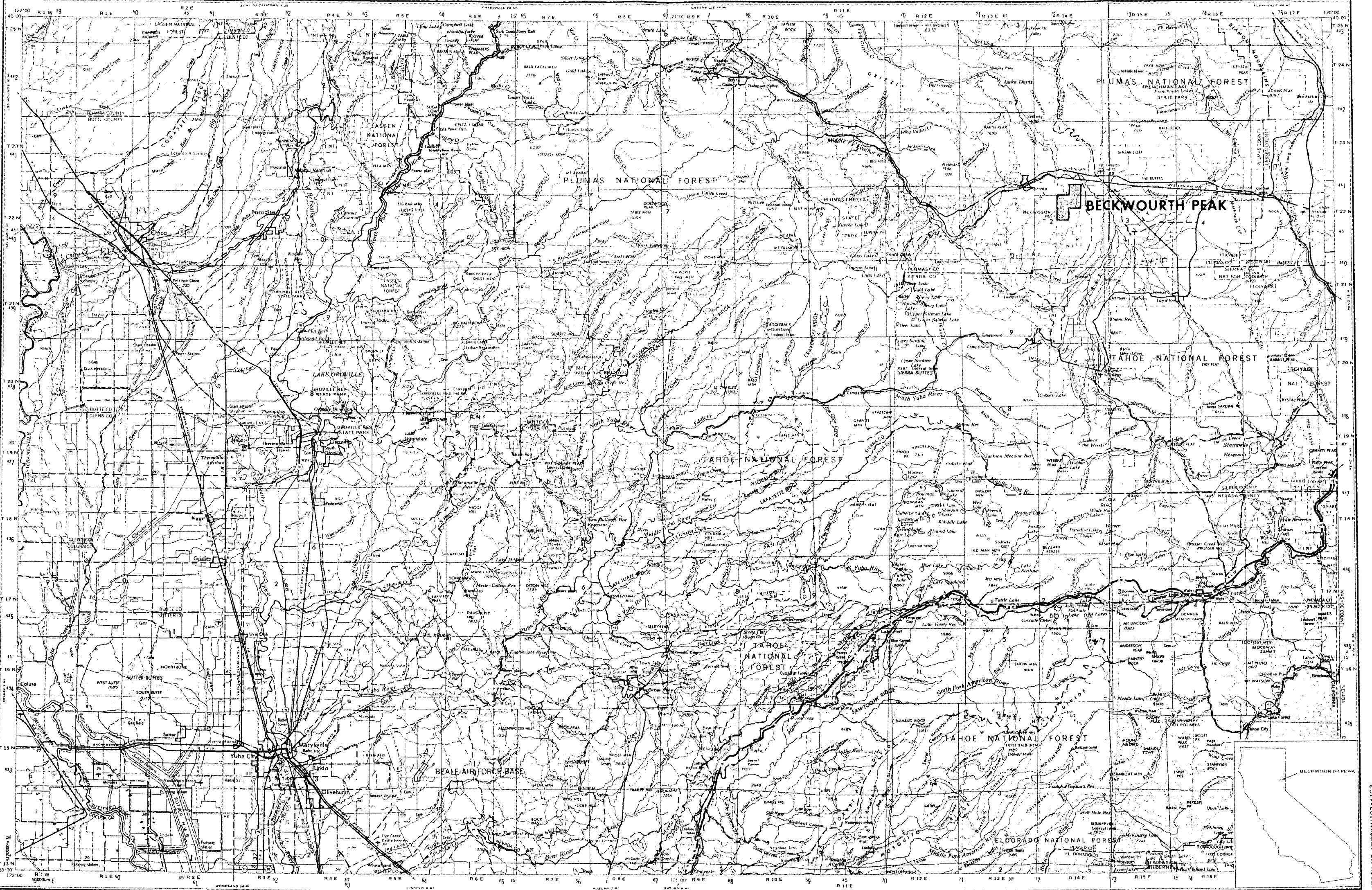

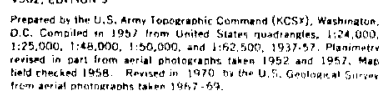

and

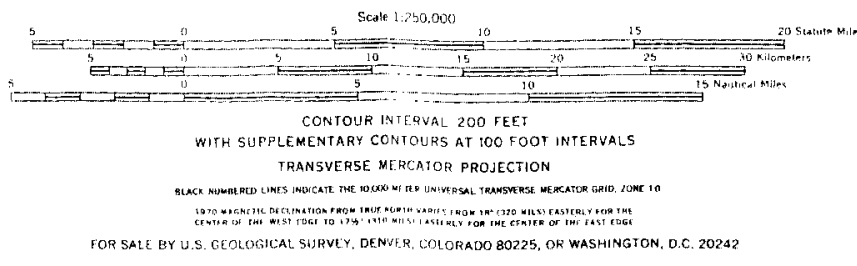

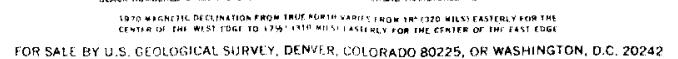

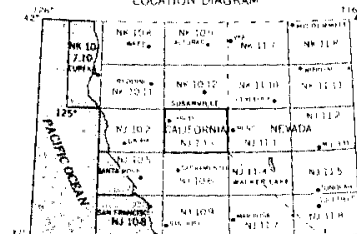

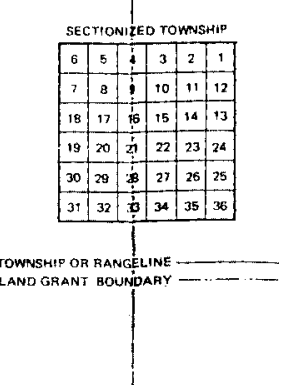

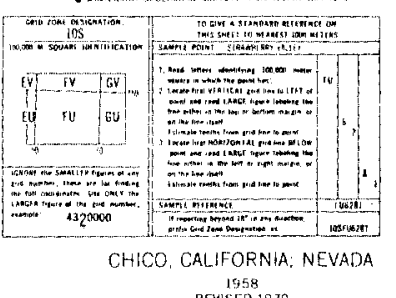


quale, pheasant, grouse, duck, and eagle). Aquatic life distribution is not known. Rare/endangered species in the area include 8 plants, 2 fish (Shortnose and Modoc Suckers) and 2 birds (the Bald Eagle and the Peregrine Falcon).

Little is known of archaeological sites in Surprise Valley. Several historical sites (Fort Bidwell, the Applegate Trail) exist.

Lassen and Wendel-Amedee Area

Roughly midway between the Lassen and Wendel-Amedee KGRAs is Susanville, seat of Lassen County. The Susan River supplies much of the irrigation water for Susanville and its surrounding area. Irrigation wells, usually with sufficient yield, supplement surface water supplies. Water quality is generally excellent, although water in the closed Honey Lake Basin is increasing in salinity from use and re-use. The reservoir of warm water underlying the town is used for geothermal heating. Utilization began about 50 years ago when managers of a lumber mill began drilling for water to cool sawing operations. They drilled several wells, but subsequently abandoned them because the water was hot. Eventually, the thermal water was used to fill the mill pond, keeping it ice-free in the winter and thereby extending the mill operating season. The zone of hot water extends from the break in slope southwest of Susanville to the Susan River; its east-west extent is not know.

The Wendel-Amedee area in the vicinity of the KGRA includes Wendel and Amedee Hot Springs and the small communities of Wendel and Amedee. The area, about 38 kilometers (24 miles) east of Susanville in Lassen County, is bounded on the southwest by Honey Lake, and on the north and northeast by Shaffer Mountain and the Amedee and Skeedaddle Mountains. Honey Lake is a remnant of Pleistocene Lake Lahontan; it is alkaline and is periodically dry in the summer. The main spur of the Southern Pacific Railroad crosses the Honey Lake basin on the east side, passing through Wendel. Other than the railroad, land use in the Wendel-Amedee area is largely confined to limited cattle grazing. Agriculture at lower elevations is restricted by the highly alkaline soils. 
The Susan River enters Honey Lake about 9 kilometers (6 miles) west of Wendel. Diversions from the river provide much of the irrigation water for the Honey Lake basin. In parts of the Wendel-Amedee area, including the immediate vicinity of Amedee Hot Spring, groundwater contains excessive concentrations of total dissolved solids, boron, fluoride, and nitrate.

Wendel Hot Springs is the site of Hobo Wells, Inc., currently northern California's only commercial geothermal agriculture development. The feasibility of geothermal greenhouses in Wendel's rigorous climate has been demonstrated by two successful tomato crops.

\section{Beckwourth Peak Area}

Bechwourth Peak KGRA is on the northwestern edge of Sierra Valley. The valley is a large square basin, about 19 kilometers (12 miles) on each side, straddling the boundary of Sierra and Plumas Counties, at an elevation of about 1, 500 meters (4,900 feet). The Middle Fork of the Feather River passes through the valley and flows westerly across its northern edge between the towns of Vinton and Portola. An arm of the valley about 11 kilometers ( 7 miles) long and 6 kilometers ( 4 miles) wide extends south to the town of Sierraville. The valley floor is sparsely populated and used largely for cattle grazing. The lumber industry, including a mill at Sattley, is a major employer.

\section{KGRA DESCRIPTIONS AND RESOURCE ESTIMATES FOR THE NORTHEAST REGION}

A brief tabulation of the location, land description, and basis for establishing the KGRA is given for each of the KGRAs in the region. An estimate of the extent of the resource and its potential is provided in Table 5-23. The KGRAs are presented alphabetically. 
Table 5-23. Estimated energy potential, Northeast Region KGRAs

\begin{tabular}{|c|c|c|c|c|}
\hline Location/KGRA & $\begin{array}{l}\text { Circular } 726 \\
\text { Designation }\end{array}$ & $\begin{array}{l}\text { Estimated } \\
\text { Reservoir } \\
\text { Temp. }{ }^{\circ} \mathrm{C}\end{array}$ & $\begin{array}{c}\text { Total } \\
\text { Reservoir } \\
\text { Heat } \\
\text { Content, } \\
\text { quads }\end{array}$ & $\begin{array}{c}\text { Electric } \\
\text { Energy } \\
\text { Potential, } \\
\text { MW for } \\
30 \text { years }\end{array}$ \\
\hline Beckwourth Peak & $*$ & - & - & - \\
\hline Glass Mountain & $*$ & - & - & - \\
\hline $\begin{array}{l}\text { Lake City-Surprise } \\
\text { Valley }\end{array}$ & Surprise Valley & 175 & 95 & 2123 \\
\hline Lassen & Morgan Springs & 210 & $\sim 5$ & 133 \\
\hline \multirow[t]{2}{*}{ Wendel-Amedee } & \multirow[t]{2}{*}{ Wendel-Amedee } & \multirow[t]{2}{*}{140} & $\sim 5$ & $* *$ \\
\hline & & & 105 & 2256 \\
\hline vailabl & & & & \\
\hline $\begin{array}{l}\text { **Indicated tempe } \\
\text { suitable for non }\end{array}$ & $\begin{array}{l}\text { e too low for } \\
\text { ric application }\end{array}$ & cial powe & enerat & \\
\hline
\end{tabular}

Beckwourth Peak KGRA

Beckwourth Peak KGRA, consisting of 2,558 acres in Plumas County, is approximately 3 kilometers ( 2 miles) southeast of Portola, California, and 1 kilometer $(0.6$ mile) southwest of Beckwourth, California.

Overlapping geothermal lease applications in the vicinity of Beckwourth Peak, Plumas County, indicate that competitive interest in the area exists. The Beckwourth Peak KGRA is based solely on competitive interest.

\section{Glass Mountain KGRA}

The Glass Mountain geothermal area, consisting of 33, 287 acres, is located in east central Siskiyou County 4.8 kilometers ( 3 miles) west of the Modoc County line, 3.2 kilometers ( 2 miles) northeast of Medicine Lake, and 
includes Mount Hoffman (elevation 2, 412 meters (7, 913 feet)) within its boundary. Lava Beds National Monument is 16 kilometers (10 miles) to the north.

Shortly after the inital list of lands valuable for geothermal resource development was published in the Federal Register (March 1967), this area was determined to be potentially valuable for geothermal resource development. On the basis of geologic evidence a 15,371-acre area was declared a KGRA. Subsequently, 17,916 acres were added to the KGRA as a result of overlapping geothermal lease applications indicating that competitive interest in the area existed.

\section{Lake City-Surprise Valley}

The 72,251-acre Lake City-Surprise Valley KGRA is located in Surprise Valley in eastern Modoc County in northeastern California, about 322 kilometers (200 miles) north of Reno, Nevada.

Surprise Valley contains numerous hot springs and other geothermal manifestations, all principally located along faults. On March 1, 1951, the Lake City hot springs and small mud volcanoes erupted in a cloud of steam, gases, and mud particles to a height of several thousand feet. These local geothermal manifestations and the geologic setting of the area prompted the initial designation of 37,160 acres as Lake City KGRA. Subsequently, 35,091 acres were added to the KGRA as a result of overlapping geothermal lease applications in the vicinity of Lake City KGRA, filed during January 1974, indicating that competitive interest in the area existed.

\section{$\underline{\text { Lassen KGRA }}$}

Lassen KGRA contains 78,642 acres astride the county line in Tehama and Plumas Counties. It is in the area of Lassen Peak, in the northeastern part of California, about 72 kilometers (45 miles) east-southeast of Redding, California. Lassen Peak is the southernmost big volcano of the Cascade Range which includes Mts. Shasta, Jefferson, Hood, St. Helena, and Rainier. 
Federal lands in the Lassen area, exclusive of those in Lassen Volcanic National Park, were considered valuable for geothermal resource development and included in a proposed withdrawal effective March 21, 1967, by publication in the Federal Register, Vol. 32, No. 57.

At least seven areas of thermal activity, including fumaroles, hot springs, and an area of small geysers, occur to the south and southeast of Lassen Peak in an irregular area of about 155 square kilometers (60 square miles). The Lassen volcanic area is characterized by Quarternary volcanic activity, dacite domes, and a possible caldera structure. The most recent eruptions occurred during 1914-15 on Lassen Peak and were preceded by eruptions at Cinder Cone within historic time. Several Pleistocene dacite domes occur in the neighborhood of Morgan Springs in the geothermal resources area. The proximity of the area to Lassen Peak and the presence of Pleistocene dacite domes within the area are indicative of a buried heat source since most known geothermal systems occur in, or near, silicic volcanoes and calderas of later Tertiary or Quarternary age.

Based on the above information, 78,642 acres in the area were designated as a KGRA.

\section{Wendel-Amedee KGRA}

The Wendel-Amedee geothermal area contains 17,292 acres and is located east and northeast of Honey Lake in southern Lassen County in northeastern California.

Federal lands in the Wendel-Amedee geothermal area were considered valuable for geothermal resource development and proposed for withdrawal from all entry effective March 21, 1967, by publication in the Federal Register, Vol. 32, No. 57.

Two hot spring areas are located within the area. One is near Wendel and the other is near Amedee siding. Temperature of the water in both areas reaches the boiling point for this altitude $96^{\circ} \mathrm{C}$. A concentration of $117 \mathrm{ppm}$ 
silica indicates a minimum base reservoir temperature of $143^{\circ} \mathrm{C}$. Pliocene and Pleistocene volcanic flows cover wide areas surrounding the geothermal area. On the basis of the foregoing local geothermal manifestations and geologic setting the area was determined to be a KGRA.

\section{COUNTy PERSPECTIVES - MODOC, LASSEN, PLUMAS, SISKIYOU, TEHAMA, AND SHASTA $*$ : THE NOR THEAST REGION}

All of the counties in the Northeast Region are economically dependent upon agriculture and/or forest products. They are not heavily populated and face problems associated with declining rural populations. The lack of employment and higher education opportunities (in some counties) has produced a common problem of decline in the youth population. All are concerned about the protection of the environment and the proper management of their natural resources for long term commercial use and personal enjoyment. Some counties are committed to the development of a recreation and tourism industry in order to diversify their economic bases. Significant proportions of the lands are managed by federal agencies. Much of the land in promising geothermal areas lies on federal acreage zoned for agriculture.

Procedural Requirements - Lassen, Modoc, Plumas, Shasta, Siskiyou, and Tehama Counties

Each of the counties, except Shasta, requires a use permit for all phases of geothermal exploration and utilization from temperature gradient testing through production of electricity or heat (Table 5-24). Modoc County has different permits for exploratory wells and production projects, patterned after Imperial County's administrative procedures. Shasta County does not have a requirement for use permits if an exploratory well is not drilled. Costs of application range from $\$ 10$ to $\$ 30$. The use permits are submitted to either the

\footnotetext{
"Shasta County, though lacking a KGRA designation within the county, is included because of its proximity to the Lassen KGRA and the possibility that the KGRA will be extended northward into the county.
} 
Table 5-24. Use permit requirements, Northeast Region - Lassen, Modoc, Plumas, Shasta, Siskiyou, and Tehama Counties

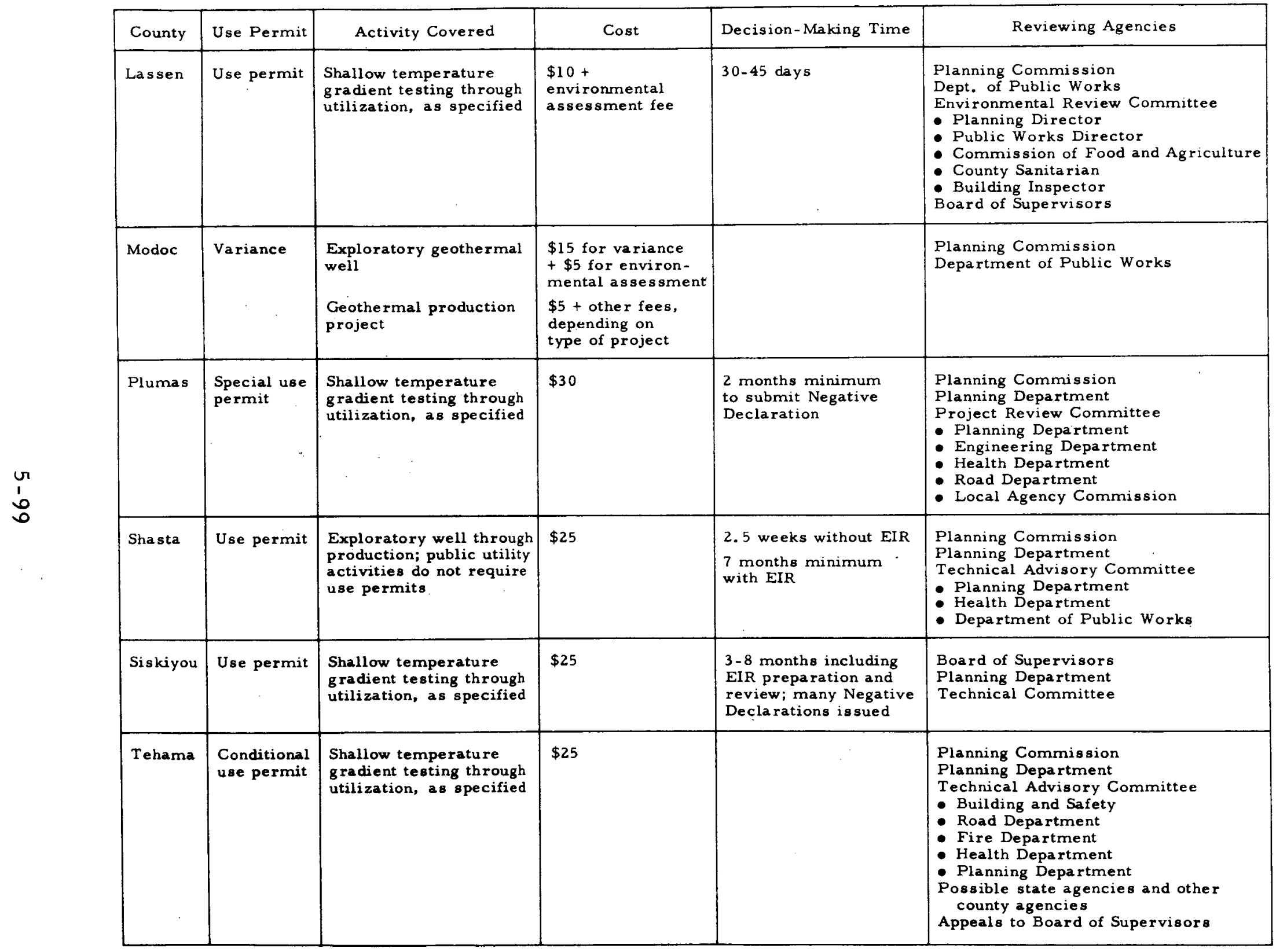


Planning Department (Plumas, Shasta, Siskiyou, and Tehama Counties) or to the Department of Public Works (Lassen and Modoc). The use permits, in conjunction with the environmental analysis and EIR, are reviewed in each county by a committee representing various county departments, e.g., Roads, Sanitation, Health, and Building and Safety.

In addition to the required use permits, one would have to prepare an environmental analysis and possibly an EIR (Table 5-25). The counties in the Northeast Region either have a county department prepare the EIR (Lassen, Modoc, Shasta, and Tehama), have a contractor to the county prepare it (Lassen, Modoc, Shasta, and Tehama), or have the applicant prepare the EIR (Modoc, Plumas, Shasta, and Siskiyou). When the county prepares the EIR, the fees are generally based upon time for preparation plus overhead. Lassen County requires a $\$ 250$ fee for processing. Each county has a technical review committee to examine the EIR and make recommendations to the decision-making body, usually the Planning Commission. Preparationand review requires a minimum of 3 months. Longer periods may, of course, occur. Modoc County, for example, requires possession of permits from both the Division of Oil and Gas and the Lahonton Water Quality Control Board prior to granting approval. It has taken up to 6 months to obtain a water discharge permit from the Lahonton Region.

\section{Energy Regulations - Lassen, Modoc, Plumas, Shasta, Siskiyou, and Tehama Counties}

In the northeast region, only Modoc County has a specific energy ordinance (Table 5-26). It is largely based upon the Imperial County Ordinance though there are a few differences. One such difference is the requirement of insurance against liability-in-tort in the amount of $\$ 2$ million, instead of $\$ 1$ million. In addition to the "Terms, Conditions, Standards and Application Procedures for Initial Geothermal Development, Modoc County", the county uses a series of zoning ordinances to determine in which areas geothermal energy exploration will be allowed with the is suance of a conditional use permit. Zones for which geothermal is explicitly identified are Agricultural-Exclusive, Commercial 
Table 5-25. EIR requirements, Northeast Region - Lassen, Modoc, Plumas, Shasta, Siskiyou, and Tehama Counties

\begin{tabular}{|c|c|c|c|c|c|}
\hline County & EIR Cost & Reviewing Agencies & Preparation by & $\begin{array}{l}\text { Decision-Making } \\
\text { Time }\end{array}$ & Comments \\
\hline Lassen & $\begin{array}{l}\text { - } \$ 15 \text { - preliminary environrien- } \\
\text { talassessment questionnaire } \\
\text { - } \$ 250-\text { EIR processing ( } \$ 15 \\
\text { credit) } \\
\text { - } \$ 20 \text { base fee for county prepa- } \\
\text { ration plus costs, or cost of } \\
\text { consultant }\end{array}$ & $\begin{array}{l}\text { - County Commissioner of } \\
\text { Food and Agriculture } \\
\text { : APCD } \\
\text { Planning Department } \\
\text { Regional Water Qual ity } \\
\text { Control Board }\end{array}$ & $\begin{array}{l}\text { - County Environmental Review } \\
\text { Committee, or } \\
\text { Consultant designated by } \\
\text { county }\end{array}$ & Unknown & $\begin{array}{l}\text { Not required, to } \\
\text { date, for any } \\
\text { geothermal } \\
\text { project }\end{array}$ \\
\hline Modoc & $\begin{array}{l}\$ 25 \text { for application processing } \\
\text { plus cost for preparation }\end{array}$ & $\begin{array}{l}\text { Department of Public } \\
\text { - works } \\
\text { Environmental Review } \\
\text { Committee: } \\
\text { OPlanning Director } \\
\text { Poard Commission } \\
\text { B Health Officer } \\
\text { : Representative(s) of } \\
\text { Public Works } \\
\text { P Disinterested citizen } \\
\text { D State and Federal } \\
\text { agencies }\end{array}$ & $\begin{array}{l}\text { Consultant to applicant, or } \\
\text { Department of public works, or } \\
\text { Consultant to county } \\
\text { Cons }\end{array}$ & Unknown & \\
\hline Plumas & $\begin{array}{l}: \begin{array}{l}\text { None for Negative Declaration } \\
\$ 11 / 1 / 4 \text { for county planner } \\
(\$ 100-150)\end{array} \\
\text { (1) }\end{array}$ & 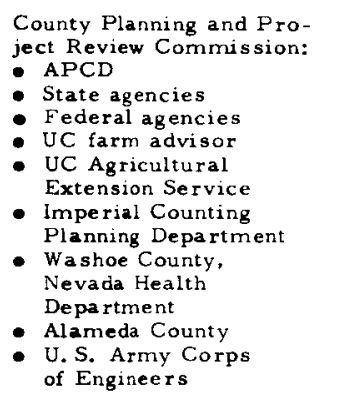 & Applicant & $\begin{array}{l}2-3 \text { months for EIR } \\
\text { preparation }\end{array}$ & \\
\hline Shasta & Cost $+20^{r}$ if county prepares & $\begin{array}{l}\text { - Roard of Administration } \\
\text { Review } \\
\text { - Technical Advisory Com- } \\
\text { mittee - decision body }\end{array}$ & $\begin{array}{l}\text { Planning Department or } \\
\text { Consultant to applicant }\end{array}$ & $\begin{array}{l}6 \text { months minimum up } \\
\text { to hearing stage }\end{array}$ & \\
\hline Siskiyou & & $\begin{array}{l}\text { - Technical Committee: } \\
\text { : Planning } \\
\text { Plealth } \\
\text { Public Works } \\
\text { : APCD } \\
\text { A Assessor } \\
\text { : Planning Commission } \\
\text { : Forest Service } \\
\text { California Division of } \\
\text { Forestry } \\
\text { - California Division of } \\
\text { Fish and Game } \\
\text { - Audubon Society, et al. }\end{array}$ & Applicant prepares EIR & $\begin{array}{l}1-6 \text { months on average } \\
\text { to prepare plus } 2 \\
\text { months for review and } \\
\text { comment; total 3-8 } \\
\text { months }\end{array}$ & $\begin{array}{l}\text { Does not send } \\
\text { to state } \\
\text { Clearinghouse }\end{array}$ \\
\hline Tehama & $\$ 350-\$ 500$ for preparation & $\begin{array}{l}\text { Planning department or } \\
\text { Consultant to county }\end{array}$ & $\begin{array}{l}\text { Planning Commission } \\
\text { Technical Advisory } \\
\text { Committee }\end{array}$ & $\begin{array}{l}4-6 \text { weeks on average } \\
\text { for prepa ration plus } \\
\text { one month for review; } \\
\text { total } 3 \text { months }\end{array}$ & \\
\hline
\end{tabular}


Table 5-26. Energy regulations, Northeast Region - Lassen, Modoc, Plumas, Shasta, Siskiyou, and Tohama Counties

\begin{tabular}{|c|c|c|c|}
\hline County & Energy Regulations & Date & Comments \\
\hline Lassen & Geothermal energy element in preparation & & \\
\hline Modoc & $\begin{array}{l}\text { Terms, conditions, standards and applica- } \\
\text { tion procedures for initial geothermal } \\
\text { development, Modoc County } \\
\text { Zoning Ordinance Number } 236 \text {, } \\
\text { Section } 10.212 \\
\text { Zoning Ordinance Number } 236 \text {, } \\
\text { Section } 10.2252 \\
\text { Zoning Ordinance Number } 236 \text {, } \\
\text { Section } 10.232 \\
\text { Zoning Ordinance Number } 236 \text {, } \\
\text { Section } 10.261 \\
\text { Zoning Ordinance Number } 236 \text {, } \\
\text { Section } 10.271\end{array}$ & May 1974 & $\begin{array}{l}\text { - Policy to encourage exploration and development } \\
\text { projects, and to increase store of knowledge } \\
\text { - Geothermal studies indicate geothermal resource } \\
\text { lies beneath agricultural areas - preservation of } \\
\text { agriculture is necessary for continued prosperity } \\
\text { - Indemnity bond of } \$ 50,000 \text { for each well drilled or } \\
\text { abandoned well re-entered or } \$ 150,000 \text { blank bond } \\
\text { - Insurance against liability-in-tort for } \$ 2 \text { million, } \\
\text { or as determined by Planning Commission } \\
\text { - Separate variances required for exploratory drill - } \\
\text { ing and for production wells } \\
\text { - Uses permitted in Agricultural - Exclusive Zone, } \\
\text { with a use permit, includes "... developing or } \\
\text { - utilization of geothermal energy..." } \\
\text { - Uses permitted in commercial forest zone, with a } \\
\text { use permit, includes "... development and use..." } \\
\text { lof] water and steam..." } \\
\text { - Uses permitted in open space, forestry, and } \\
\text { grazing zone, with a use permit, includes } \\
\text { "...expioring for, development, or utilization of } \\
\text { geothermal energy" } \\
\text { - Uses permitted in Commercial Zone includes } \\
\text { greenhouses } \\
\text { - Uses permitted in Industrial Zone include } \\
\text { "... manufacturing, processing, or research, } \\
\text { provided that no odor, gas, fumes, dust, etc., is } \\
\text { produced or omitted beyond the confines of the } \\
\text { lot..." }\end{array}$ \\
\hline Plumas & $\begin{array}{l}\text { Geothermal energy element in preparation, } \\
\text { also revision of zoning specifications to } \\
\text { include geothermal }\end{array}$ & & \\
\hline Shasta & None & & \\
\hline Siskiyou & None & & \\
\hline Tehama & $\begin{array}{l}\text { Drafting energy ext raction ordinance with } \\
\text { Colusa and Glenn Counties }\end{array}$ & & \\
\hline
\end{tabular}


Forest and Open Space, Forestry, and Grazing. In addition, it appears possible to develop geothermal in both Commercial and Industrial Zones. Lassen, Plumas, and Tehama Counties are preparing ordinances or additions to the General Plan for geothermal energy development. Plumas County, through zoning ordinances, currently allows mining and extraction of mineral, hydrocarbon, and thermal resources. Siskiyou and Shasta Counties currently have no ordinances or regulations specific to energy exploitation.

The most stringent requirements are to be found in Modoc County. It requires indemnity bonds and insurance against liability-in-tort at rates far above those currently required for oil and gas exploration. The premiums for the bonds and insurance together could be as high as $\$ 7,500-\$ 8,500$ or about 2 percent of the cost of an exploratory well (based on $\$ 500,000$ per well). These figures should not be construed as precise, but are believed to be "in the ballpark". There has been little experience with geothermal energy bonding and insurance. These estimates were predicated on practices used in oil and gas. The impact of these detailed ordinances is primarily one of some time delay, the duration of which is difficult to ascertain. The added financial obligations do not appear to cause exceptional hardship. The monitoring programs do impose requirements which have generally not been levied heretofore. But, with the passage of federal and state legislation in the environmental sphere, one would anticipate that these requirements are necessary to ensure better decisions with regard to the environment. And, of course, geothermal energy development does not have this as a unique imposition upon its activity. In addition to these requirements, some of these four counties require monitoring programs for noise and subsidence, permits from the Division of Oil and Gas, and the appropriate Water Quality Control Board, and development of a Geothermal Energy Element for the County General Plan.

The Future-Lassen, Modoc, Plumas, Shasta, Siskiyou, and Tehama Counties

Only Lassen and Modoc Counties have had a substantive, working knowledge of geothermal energy. The other counties evidence little knowledge on the subject, even when there has been an attempt to get information. Accessibility to information is severely limited. A surprising situation occurred in Plumas County where it was discovered that the USGS had not informed the 
county of the KGRA classifications of Beckwourth Peak. Most of the counties in discussing use permit and EIR requirements and processing had to do so by reference to other activities in their counties. Siskiyou, Shasta, and Tehama County officials have had no direct regulatory experience with geothermal energy developers. The activity in Modoc, Lassen, and Plumas has been primarily on federal lands.

One gets the impression that the largest problems energy developers will face in these counties are (1) locational inaccessibility impacting the ability to bring in equipment, and to market goods produced subsequent to the use of geothermal heat, (2) the difficulty small communities would experience from any significant increase in population (including the provision of services employed in exploiting geothermal energy), and (3) the fundamental requirement to preserve other natural resources for commercial exploitation. Any interference in the latter would undoubtedly be strongly resisted. Nonetheless all of these counties, particularly the more easterly three, are facing the need to bolster local economies, to retain population, and to manage the growth of an enlarging recreational enterprise. To the extent that geothermal can meet these criteria and needs it-will be a welcome participant in each county's activities. Certainly Lassen County has demonstrated strong interest in developing geothermal energy with the Susanville project, designed to develop electricity at cheaper rates and jobs for the local economy.

\section{GEOTHERMAL DEVELOPMENT STATUS IN THE NORTHEAST REGION}

There is very little geothermal development activity in the region. At Susanville, in Lassen County, an effort is being made to study the feasibility of developing the geothermal resource in the area and the economic impact this will have on the region in attracting new industries, creating employment opportunities, and increasing the local revenue base. The study is being conducted by private consultants, VTN and CSL Associates under contract with ERDA. 
Some cxploratory drilling has been done in the Lake City-Surprise Valley KGRA by American Thermal Resources, Gulf Oil Company, and Magma Energy Inc. All these wells are presently either abandoned or idle. Outside the KGRA, to the west near Alturas, a well drilled by Geothermal Resources International, Inc., in 1969, resulted in a dry hole. Wells have also been drilled in the Wendel-Amedee, Honey Lake area by Gulf Oil, Magma Power Company (in 1952), and Neaves Fetroleum Development Company which were dry holes or not commercially viable. In the other KGRAs - Beckwourth Peak, Giass Mountain, and Lassen - there is no reported geothermal development activity. However, Phillips Petroleum Company, early in 1974, drilled a 914-meter (3,000-foot) geothermal test well southeast of the Beckwourth Peak KGRA on land leased from Getty Oil Company. The well was subsequently abandoned. The recent well drilling operations in the Northeast Region are given in Table 5-27.

Table 5-27. Wells drilled, Northeast Region, 1971-75 (based on files of Division of Oil and Gas)

\begin{tabular}{|c|c|c|c|c|c|c|c|}
\hline Operator & Pre-1971 & 1971 & 1972 & 1973 & 1974 & 1975 & $\begin{array}{c}\text { Total } \\
1971-75\end{array}$ \\
\hline $\begin{array}{l}\text { American Thermal } \\
\text { Resources, Inc. } \\
\text { Gulf Oil Corp. } \\
\text { Kelley Hot Springs, Ltd. } \\
\text { Magma Power Co. } \\
\text { Phillips Petroleum Co. } \\
\text { Others (Pre-1971) }\end{array}$ & 1 & & 1 & 1 & 1 & & $\begin{array}{l}1 \\
4 \\
1 \\
1 \\
1\end{array}$ \\
\hline Totals & 13 & 0 & 1 & 5 & 2 & & 8 \\
\hline
\end{tabular}




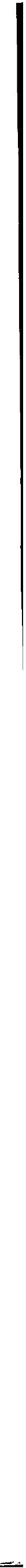


CENTRAL COAST REGION

REGIONAL OVERVIEW

The Central Coast Region extends from the Sespe Hot Springs area in Ventura County, about 11 kilometers ( 7 miles) nor thwest of the town of Fillmore (Fig. 5-11), to the Diablo Range in Santa Clara County, east of Gilroy.

Sespe Hot Springs Area

Ventura County, in which the Sespe Hot Springs KGRA is located, is an area of sharp physical contrasts ranging from the Pacific Ocean through a fertile coastal plain and broad river valleys to a rugged mountainous interior region, which is part of the Transverse Ranges. The highest peak in the county is Mt. Pinos, 2692 meters (8,831 feet), in the Pine Mountains. In the northern half of the county are the San Rafael Mountains. The Santa Susana and Santa Monica mountains are in the southwestern part.*

The mountains and deeply eroded canyons run in a general east-west direction in conformity with the geological structure of the transverse ranges of southern California. Most of the county drains to the ocean through three major rivers, the Santa Clara and Ventura in the western section and the Calleguas Creek and its tributaries on the southern border. Because of the extensive conservation projects, little water reaches the Pacific Ocean from the rivers.

Ventura County ranks thirteenth in the state in total population. Establishment of new industries and improved transportation have led to rapid home building. Agriculture is also important. Almost all of the people live in the river valleys and on the coastal plain in the souther $n$ half of the county.*

Ventura County is among the leading producers of lemons and oranges in the state, and vegetables, primarily celery, tomatoes, and lettuce, are also grown. Livestock and poultry raising are major activities in the county, and petroleum and natural gas production also contribute to the economy. Important industries are transportation equipment manufacture, electrical machinery, food processing, and nonelectrical machinery. Camping, picnicking, and fresh water sports are available at several lakes, parks, and recreation areas. The Ojai Valley, with hundreds of miles of riding and hiking trails, *From California Information Almanac (see p. 5-113, item 8), with permission. 
lies at the base of Los Padres National Forest, Fishing, hunting, and camping can be enjoyed in this rugged mountain area. The Mt. Pinos Recreation Area offers snow fun in winter. Near the KGRA is the Sespe Wildlife Area where 53, 000 acres are set aside as a refuge for North America's largest bird, the rare (and endangered) California condor. *

Diablo Range Area

At the northern end of the Region, the Diablo Range area shows promise as a potential geothermal area. Although it has not been designated as a KGRA by the U.S. Geological Survey, considerable interest has been shown by private organizations in exploring and developing the geothermal potential of the area. Santa Clara County is typical of the three-county area of interest, with some portions of the area lying in Stanislaus and Merced Counties.

Santa Clara County lies at the south end of San Francisco Bay, between the Santa Cruz Mountains and the Diablo Range. Its dominant feature is the broad, level Santa Clara Valley, a productive alluvial lowland. Elevations vary from sea level to 122 meters (400 feet) on the plain, and rise to over 1220 meters $(4,000 \mathrm{feet})$ in the mountains which flank the valley. Mt. Hamilton, with an elevation of 1283 meters $(4,209 \mathrm{feet})$, is the location of the Lick Observatory.*

The county, one of California's leading growth areas, was fifth in total population and sixth in average population density in 1970 when the population reached 1,066,714. This was primarily because of increasing urbanization as part of the San Francisco Bay metropolitan area. Orchards and farms have given way to subdivisions and industries. Freeways allow rapid commuting. The greatest growth and densest population are in and around San Jose.*

Fig. 5-11. Sespe Hot Springs KGRA-Central Coast Region (opposite) *Ibid. 


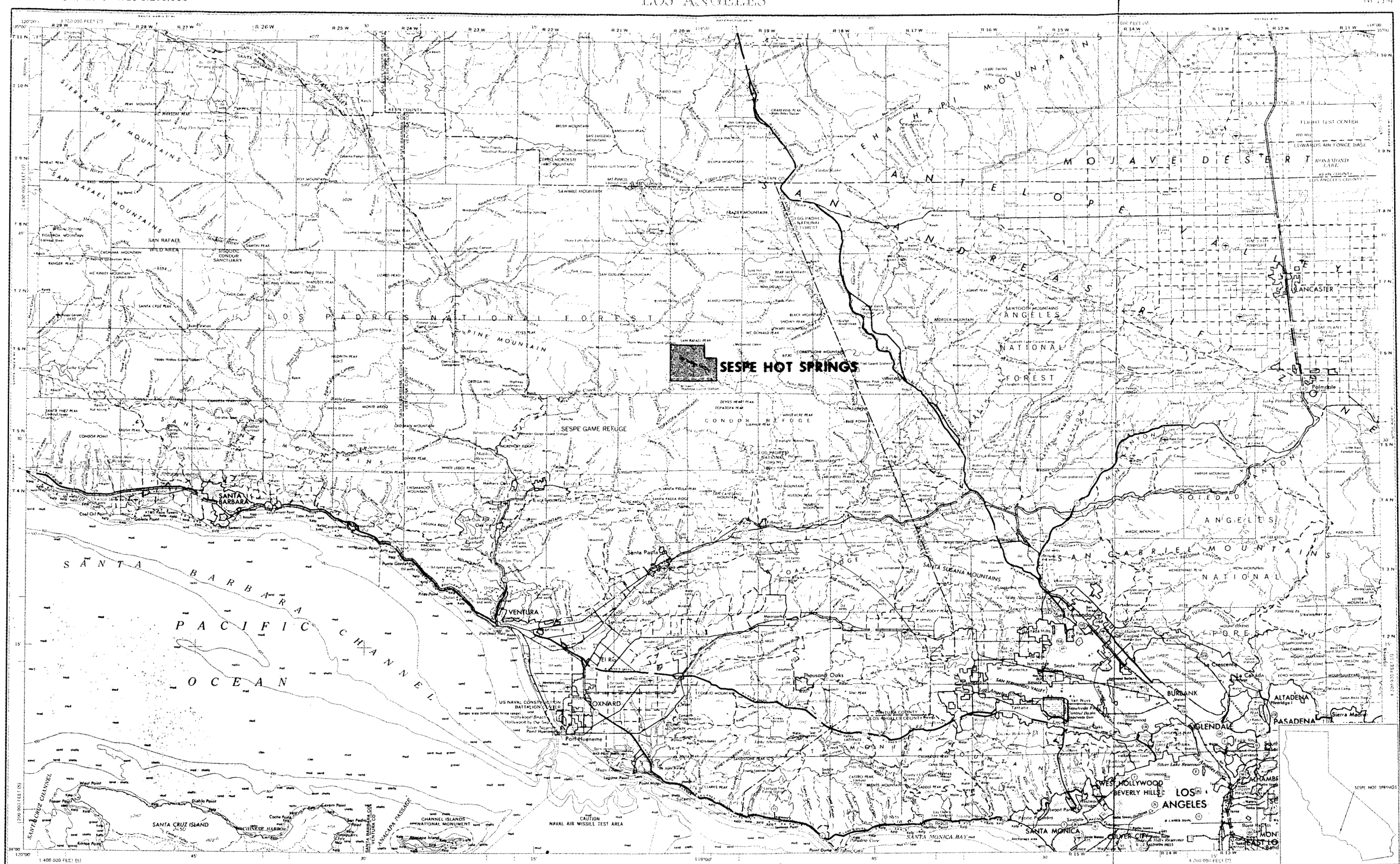

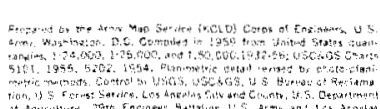
$v^{2}=$

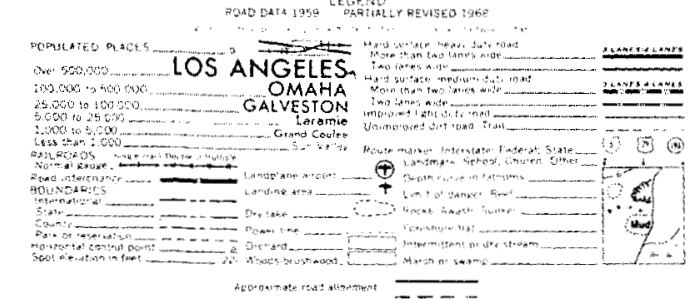

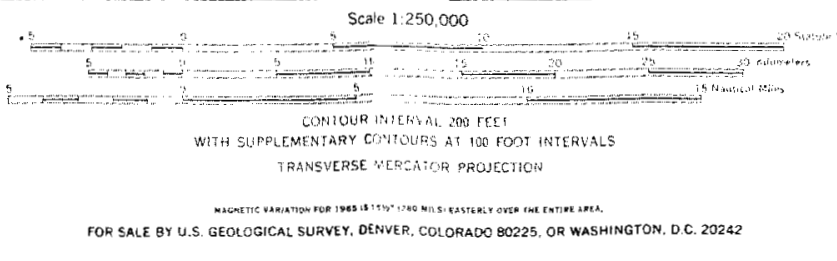

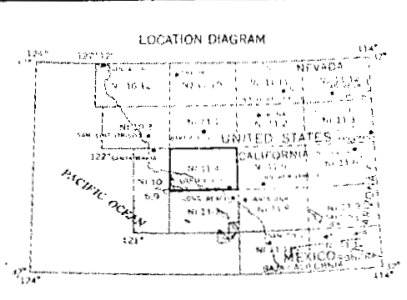

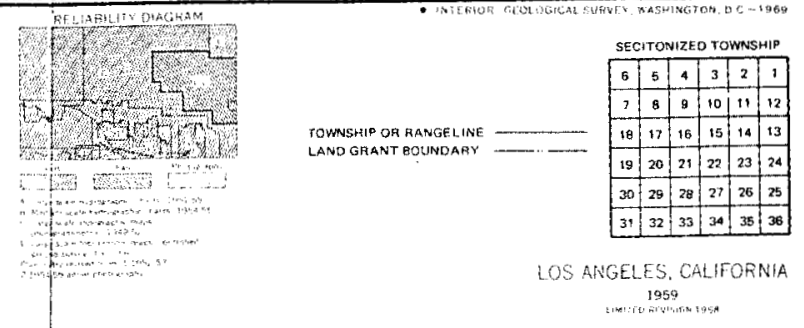



Manufacturing is a major economic base of the county. In terms of both employment and payrolls the most important industry is electrical machinery. Other large employers include electronic components, ordnance and accessories, nonelectrical machinery, food processing, transportation equipment, printing and publishing, and fabricated metal products.*

Agricultural activities include livestock and poultry $r$ aising, and their products. Nursery products, mostly cut flowers, and vegetables and fruit are also grown.

KGRA DESCRIPTION AND RESOURCE ESTIMA TES FOR THE CENTRAL COAST REGION

A brief tabulation of the location and basis for establishing the KGRA is given for the only KGRA in the Region. The estimated reservoir temperature and heat content are shown in $\mathrm{T}_{\text {able }}$ 5-28.

Sespe Hot Springs KGRA

The Sespe Hot Springs KGRA, containing 7,034 acres, is located about 11 kilometers (7 miles) northwest of the town of Fillmore, east of Pine Mountain and north of Sespe Creek in northeastern Ventura County.

Shortly after the initial list of lands valuable for geothermal resource development was published in the Federal Register (March 1967), this area was determined to be potentially valuable for geothermal resource development. Thermal springs in the area and the local geologic setting formed the basis for designation of the area as the Sespe Hot Springs KGRA.

\section{GEOTHERMAL DEVELOPMENT STATUS IN THE CENTRAL COAST REGION}

There has been no development activity in the Sespe Hot Springs KGRA. No geothermal wells have been drilled and no detailed geophysical or geochemical data is available. The area thus remains untested. 
Table 5-28. Estimated energy potential, Central Coast Region KGRA

\begin{tabular}{|c|c|c|c|c|}
\hline Location/KGRA & $\begin{array}{c}\text { Circular 726 } \\
\text { Designation }\end{array}$ & $\begin{array}{c}\text { Estimated } \\
\text { Reservoir } \\
\text { Temp. }{ }^{\circ} \mathrm{C}\end{array}$ & $\begin{array}{c}\text { Total } \\
\text { Reservoir } \\
\text { Heat } \\
\text { Content, } \\
\text { quads }\end{array}$ & $\begin{array}{c}\text { Electric } \\
\text { Energy } \\
\text { Potential, } \\
\text { MWe for } \\
30 \text { years }\end{array}$ \\
\hline Sespe Hot Springs & Sespe Hot Spg. & 155 & 1 & $*$ \\
\hline
\end{tabular}

*Indicated heat content too small for commercial power generation.

Further north in the Diablo Range east of Gilroy, there is evidence of exploratory interest in the geothermal potential of the area. Diablo Exploration Inc. is seeking support from ERDA to aid in exploration of geothermal resources within three counties: Merced, Santa Clara, and Stanislaus. The area of investigation will range southward from the Alameda-Santa Clara county line to the Mercy Hot Springs area. The City of Santa Clara is a cosponsor of the project. Should exploration show the resource to be promising the company plans to study the feasibility of piping hot waters from potentially productive wells to the Gilroy area for use by the canning industry. 
BIBLIOGRAPHY

Much of the descriptive data in this section was drawn directly from the following sources:

1. Final Environmental Statement for the Geothermal Leasing Program. U.S. Department of the Interior 1973. U.S. Government Printing Office Stock Number 2400-00790.

2. Descriptions of Northern California Low Temperature Geothermal Resource Areas, State of California Division of Oil and Gas Report Number TR 13 dated 1975.

3. A Study of Geothermal Prospects in the Western United States. Final Report No. 28455-6001-RU-0020 August 1975 TRW Systems Group, Redondo Beach, California.

4. California Known Geothermal Resource Minutes of the Mineral Land Evaluation Committee, United States Department of the Interior, Geological Survey, Western Region.

5. Thermal Springs of the U.S. and other Countries, Waring G.A, U.S. Geological Survey Prof Paper 492, 1965.

6. Water and Power from Geothermal Resources in California, The Resources Agency, Department of Water Resources.

7. California State Lands Commission: Environmental Impact Report, Gulf Oil Company, 1974.

8. California Information Almanac, Past, Present, Future California Almanac Company, 1973.

9. 60th Annual Report of the State Oil and Gas Supervisor, Division of Oil and Gas, Report No. PRO 61974.

10. California Summary of Operations. 59th Annual Report of the State Oil and Gas Supervisor, Division of Oil and Gas, Volume 59, No. 21973.

11. California Summary of Operations. 58th Annual Report of the State Oil and Gas Supervisor, Division of Oil and Gas, Volume 58, No. 21972.

12. California Summary of Operations. 57th Annual Report of the State Oil and Gas Supervisor, Division of Oil and Gas, Volume 57, No. 21971.

13. Summary of the Project Coordination Council Meeting February 18, 1976, Pierson, D.E., Director of Public Works, Imperial County, California.

14. Geothermal Hot Line Volume 5 No. 2 Sept. 1975. 



\section{SECTION VI}

\section{RESEARCH AND DEVELOPMENT}

Research and development activities related to geothermal energy are being supported by both private and public funds, and are being conducted in private industries, universities, and national laboratories. The exact level of investment in geothermal-related $R \& D$ is difficult to determine, but the single largest contributor is the federal government. The federal investment is primarily channeled through the Energy Research and Development Administration (ERDA). As an indicator of the trend in emphasis on geothermal energy, therefore, the funding history of geothermal R\&D by ERDA and its predecessor agencies is instructive. In fiscal year 1974, the National Science Foundation (NSF) and the Atomic Energy Commission (AEC) spent a combined total of $\$ 9$ million for geothermal R\&D, primarily on in-house activities at the National Laboratories and in university grants. In FY'75, the year ERDA was formed, 'geothermal R\&D funding increased to $\$ 20$ million, and in FY'76 further increased to $\$ 35$ million. The FY'77 budget request, exclusive of the Loan Guaranty Program, is $\$ 45$ million. Thus, in 3 years, the rate of federal investment has increased by a factor of five.

Much of the increase in federal funding has gone to broadening the federal government's support to private industry through $R \& D$ contracts and cost-shared projects. ERDA, in its testimony to Congress in support of the FY'77 budget, has emphasized the need for early growth of a geothermal industrial base, and is stressing increased industrial participation in the federal R\&D program. This should accelerate the commercialization of government-sponsored te chnology developments.

This section of the report will present a summary of ongoing R\&D activities that could impact on future geothermal development in the State of California. These activities have been grouped in the following categories:

1. Exploration and Assessment Technology.

2. Resource Extraction Technology.

3. Resource Utilization Technology. 
4. Environmental Effects and Abatement Technology.

5. Legal and Institutional Studies.

6. Planning Efforts and Economic Studies.

Although the list presented here does include most of the ongoing activities in the nation, it is not necessarily complete. Many industries also have development programs, but in most cases they are proprietary. Other federal agencies in addition to ERDA, NSF, and the U.S. Geological Survey (USGS), are initiating geothermal-energy-oriented $R \& D$ programs. However, the list does give a good overall indication of the major thrusts in geothermal $R \& D$ today.

\section{EXPLORATION AND ASSESSMENT TECHNOLOGY}

Geothermal exploration has been characterized as being in a technological state equivalent to that of oil and gas exploration 50 years ago. Improvements in the ability to find and assess the capacity of geothermal resources are needed to make exploration for geothermal resources an attractive alternative in the competition for venture capital. Recognizing this, the federal government has placed high priority on the development of exploration technology.

Efforts in this area are grouped in three categories:

- Exploration Technology. Development of improved geophysical, geological, and geochemical techniques for locating geothermal reservoirs and thereby increase the success ratio in exploratory drilling.

- Reservoir Modeling. Development of improved models to predict reservoir capacities and thereby reduce the time and cost of establishing confidence in the probable commercial life of reservoirs.

- Well-Logging Equipment. Increase the quality of, and reduce the cost of obtaining, data needed to assess the properties and probable extent of geothermal reservoirs. 
Efforts in these areas have been supported by NSF, USGS, and ERDA; the latter has now been given lead agency responsibility for this work. The re has also been significant privately-funded R\&D, partcularly in the area of reservoir modeling. ERDA funding in this area was $\$ 2.957$ million in FY'75, and $\$ 4.2$ million in FY'76 (including the transition quarter). The FY'77 budget request is $\$ 9.7$ million, reflecting the priority being given this work. In FY'77, ERDA plans to inaugurate a major effort in the development of case histories of geothermal reservoirs, to develop a data base against which the reservoir models can be tested. ERDA also plans a major effort in confirmation and exploration techniques. This work will be carried out cooperatively with USGS.

Specific efforts presently ongoing in the area are shown in Table 6-1. In addition to the se programs, ERDA is currently planning to obligate an additional $\$ 700 \mathrm{~K}$ in the exploration and modeling areas in FY'76.

\section{$\underline{\text { RESOURCE EXTRACTION TECHNOLOGY }}$}

$\mathrm{R} \& \mathrm{D}$ activities in resource extraction technology are directed at improving the economics of geothermal field development by (1) reducing the cost of drilling, (2) reducing the cost of well maintenance, and (3) increasing well productivity. The primary public sector funding source for the se activities is the ERDA Division of Geothermal Energy; its program is summarized in Table 6-2. There is little private sector activity directed specifically at geothermal applications because of the limited market seen by the equipment manufacturers; however, developments aimed at petroleum field applications may be significant to geothermal. Little information is available on these programs because of their highly proprietary nature.

\section{Efforts to Reduce the Cost of Drilling}

Efforts to reduce the cost of drilling include development of improved conventional drill bits, of novel drilling techniques, and of improved drilling fluids for high temperature operations. ERDA and its predecessor agencies (AEC and NSF) obligated $\$ 1.9$ million in FY'75 in this area, and ERDA plans 
Table 6-1. Current R\&D programs in geothermal exploration and assessment technology

-

\begin{tabular}{|c|c|c|}
\hline Program & Contractor & Funding/Source \\
\hline \multicolumn{3}{|c|}{ EXPLORATION TECHNIQUES* } \\
\hline $\begin{array}{l}\text { Development of Criteria Useful in the Detection of } \\
\text { Low Permeability Geothermal Systems }\end{array}$ & $\begin{array}{l}\text { Univ. of Arizona, } \\
\text { Tucson, Arizona }\end{array}$ & $\$ 133 \mathrm{~K} / \mathrm{ERDA}$ \\
\hline Assessment of Hydrothermal Resources & $\begin{array}{l}\text { Lawrence Berkley } \\
\text { Laboratory }\end{array}$ & 1) $239 \mathrm{~K} / \mathrm{ERDA}$ \\
\hline Probes for Heat Flow and Conductivity Measurements & $\begin{array}{l}\text { Univ. of Calif., } \\
\text { Berkeley }\end{array}$ & $\begin{array}{l}40 \mathrm{~K} / \\
\text { (Calif. State Lands Commission) }\end{array}$ \\
\hline \multicolumn{3}{|c|}{ RESERVOIR MODELING } \\
\hline Two-Phase Flow in Geothermal Energy Systems & $\begin{array}{l}\text { Univ. of Denver } \\
\text { Research Institute }\end{array}$ & $378 \mathrm{~K} / \mathrm{ERDA}$ \\
\hline $\begin{array}{l}\text { Computer Model of a Geothermal Reservoir (part of } \\
\text { subsidence contract) }\end{array}$ & $\begin{array}{l}\text { Systems, Science, } \\
\text { and Softwa re, Inc. }\end{array}$ & (NSF-RANN) \\
\hline Development of a Model for the Salton Sea Reservoir & $\begin{array}{l}\text { Lawrence Livermore } \\
\text { Laboratory }\end{array}$ & ERDA \\
\hline Reservoir Modeling & Stanford Univ. & Private \\
\hline \multicolumn{3}{|c|}{ WELL-LOGGING EQUIPMENT } \\
\hline Geothermal Down-Well Instrumentation Development & $\begin{array}{l}\text { Sperry Research } \\
\text { Center }\end{array}$ & $200 \mathrm{~K} / \mathrm{ERDA}$ \\
\hline Experimental Evaluation of Well-Logging Cables & $\begin{array}{l}\text { Systems, Science, } \\
\text { and Software, Inc. }\end{array}$ & (Under negotiation) \\
\hline $\begin{array}{l}\text { *In addition to these efforts, USGS has had an active } p \\
\text { for finding and as sessing geothermal reservoirs. Th } \\
\text { FY'77 because of a budget reduction from } \$ 9 \text { million } \\
\text { activities. }\end{array}$ & $\begin{array}{l}\text { the development an } \\
\text { will probably be seve } \\
\text { to } \$ 3 \text { million in } F Y^{\prime} 7\end{array}$ & $\begin{array}{l}\text { ig of techniques } \\
\text { artailed in } \\
\text { SGS geothermal }\end{array}$ \\
\hline
\end{tabular}


Table 6-2. ERDA R\&D programs for improving geothermal resource extraction technology, as of Feb. 1, 1976

\begin{tabular}{|c|c|c|c|c|}
\hline Program & Contractor & \multicolumn{3}{|c|}{ Funding } \\
\hline \multicolumn{5}{|c|}{ DRILLING TECHNOLOGY" } \\
\hline Development of Water Jet Drilling Technology & Univ. of Missouri & $\begin{array}{l}\text { FY'75 contract value } \\
\text { FY' } 76 \text { follow-on estimate }\end{array}$ & $\$ 151 \mathrm{~K}$ & $\$ 150 \mathrm{~K}$ \\
\hline $\begin{array}{l}\text { Design and Testing of an Improved Drill Bit } \\
\text { for Geothermal Applications }\end{array}$ & Terra-Tek & $\begin{array}{l}\text { FY'75 contract value } \\
\text { F' } 76 \text { follow-on estimate }\end{array}$ & $358 \mathrm{~K}$ & $200 \mathrm{~K}$ \\
\hline $\begin{array}{l}\text { Development of Rock-Melting Drilling Tech- } \\
\text { niques (Subterrene Program) }\end{array}$ & Los Alamos Scientific Lab. & $\begin{array}{l}\text { FY'75 costs } \\
\text { FY'76 estimate }\end{array}$ & $912 \mathrm{~K}$ & $900 \mathrm{~K}$ \\
\hline $\begin{array}{l}\text { Development of a Drill Bit With Replaceable } \\
\text { Cutting Surfaces; Development of Advanced } \\
\text { Spark Drilling. Techniques; and Development } \\
\text { of Projectile Drilling Techniques } \\
\text { (Terradynamic Drilling) }\end{array}$ & Sandia Laboratories & $\begin{array}{l}\text { FY'75 costs } \\
\text { FY'76 estimate }\end{array}$ & $482 \mathrm{~K}$ & $1,100 \mathrm{~K}$ \\
\hline Development of Jet Coring Techniques & Flow Research Corp. & FY'76 contract & & $150 \mathrm{~K}$ \\
\hline Improvement in Down-Hole Drill Motors & Terra-Tek & $\begin{array}{l}\text { FY' } 76 \text { contract estimate } \\
\text { (in negotiation) }\end{array}$ & & $500 \mathrm{~K}$ \\
\hline \multicolumn{5}{|c|}{ DOWN-HOLE PUMPS } \\
\hline $\begin{array}{l}\text { Development of a Small Electric Down-Hole } \\
\text { Pump Capable of Operating in } 400^{\circ} \mathrm{F} \\
\text { Environment }\end{array}$ & Lear Motors & & & \\
\hline $\begin{array}{l}\text { Development of a Down-Hole Turbine-Pump } \\
\text { Capable of Operating in } 400^{\circ} \mathrm{F} \text { Environment }\end{array}$ & Sperry Rand Corp. & & & \\
\hline $\begin{array}{l}\text { Development of a Turbine-Driven Pump Capa- } \\
\text { ble of Operating in a } 650^{\circ} \mathrm{F} \text { Environment }\end{array}$ & Sundstrand Corp. & & & \\
\hline
\end{tabular}


to obligate $\$ 3.45$ million in $F Y^{\prime} 76$. The FY'77 budget request includes $\$ 4.5$ million for drilling technology.

In addition to the ERDA drilling technology programs shown in Table 6-2, there is a large private sector effort directed at improvements in drilling technology for high temperature and hard rock environments. Although these efforts are primarily aimed at petroleum drilling, they could be applicable to geothermal. Firms known to have active development programs include Hughes Tool Co., Reed Tool Co., Smith International, and Dresser Industries.

Efforts to Reduce the Cost of Well Maintenance

ERDA has not yet formulated a specific R\&D program element for efforts to reduce well maintenance costs, although the programs noted in brine chemistry and materials research in the Resource Utilization Technolog y Section below are largely applicable. In the private sector, Union Oil Co, has been developing an improved cement for high temperature geothermal applications.

Efforts To Increase Well Productivity

Two types of activities are directed toward increasing well productivity? the development of well stimulation techniques, and the development of down hole pumps (Table 6-2).

ERDA is presently in the process of formulating its program in the area of well stimulation, and no details are available. It has budgeted $\$ 1.23$ million for this area in FY'76, and has requested $\$ 1$ million in FY'77.

\section{RESOURCE UTILIZATION TECHNOLOGY}

Activities in this category are directed at improving the economics of geothermal plant operation by (1) increasing the plant availability factor (reducing downtime) and (2) increasing the cycle efficiency. The ERDA Division of Geothermal Energy is the principal source of funding for these activities; other funding sources include the California Energy Resources Conservation and Development Commission and the Electric Power Research 
Institute. In addition, active programs have been carried out by San Diego Gas and Electric Company and Southern California Edison. Some component development activities have also been initiated by industrial manufacturers.

Efforts To Increase Plant Availability Factor

Major factors in determining the economic viability of geothermal development are the reliability of equipment operating with hot corrosive brines, the equipment maintenance and/or replacement schedules required, and the downtime associated with maintenance and replacement, both scheduled and unscheduled. These factors combine to form the plant availability factor, the fraction of the total time that the plant is actually operational. Efforts directed primarily at improving plant availability include brine chemistry and materials research, and improved maintenance techniques. ERDA programs in the se areas include those shown in Table 6-3.

Table 6-3. ERDA R\&D programs for improvement of materials technology

\begin{tabular}{|l|l|ll|}
\hline \multicolumn{1}{|c|}{ Program } & \multicolumn{1}{|c|}{ Contractor } & \multicolumn{1}{|c|}{ Funding } \\
\hline $\begin{array}{l}\text { Materials Research and } \\
\text { Evaluation for Geothermal } \\
\text { Corrosive Environments }\end{array}$ & $\begin{array}{l}\text { Case Western } \\
\text { Reserve Univ. }\end{array}$ & FY'75 contract \$324K \\
$\begin{array}{l}\text { A Study of Silica Scaling } \\
\text { From Geothermal Brines }\end{array}$ & $\begin{array}{l}\text { Environmental Impact } \\
\text { Center, Inc. } \\
\text { Oak Ridge National } \\
\text { Precipitation Scaling and }\end{array}$ & FY'75 contract & $289 \mathrm{~K}$ \\
$\begin{array}{l}\text { Corrosion Studies } \\
\text { Mvaluation of Alternate } \\
\text { Applications }\end{array}$ & $\begin{array}{l}\text { Battelle Northwest } \\
\text { Laboratories }\end{array}$ & FY'75 costs & 373K \\
$\begin{array}{l}\text { Erosion Cavitation Applied } \\
\text { to Heat Exchanger Tubes }\end{array}$ & $\begin{array}{l}\text { Daedalean } \\
\text { Associates }\end{array}$ & FY'76 contract & 100K \\
\hline
\end{tabular}

* For additional materials technology programs see Table 6-6. 
Efforts To Increase Cycle Efficiency

Improvements of overall conversion efficiency will be the key to economic utilization of lower temperature resources. Efforts here include ERDA - funded programs and programs funded by utilities and equipment manufacturers. These programs include development of improved components, analysis of new cycles, and the design and construction of test facilities to demonstrate component and system performance. The programs presently under way includes those shown in Table 6-4.

\section{ENVIRONMENTAL EFFECTS AND ABATEMENT TECHNOLOGY}

A substantial effort is being devoted to the identification, evaluation, and amelioration of the potential environmental effects of geothermal development. These efforts can be grouped into four categories:

- Background Studies. Measurement of present subsidence rates, levels of seismic activity, ambient noise levels, water quality, and air quality in potential geothermal areas.

- Evaluation/Prediction Techniques. Determination of threshold levels at which geothermal operations could start to impact the environment, and development of predictive techniques for assessing overall impacts of different levels of geothermal operations.

- Monitoring Techniques. Development of improved techniques/ equipment for monitoring the effects of geothermal operations.

- Abatement Techniques. Development of improved techniques/ technology for reducing undesirable effects of geothermal operations.

A number of state and federal agencies have supported these efforts, including ERDA, NSF, the Environmental Protection Agency (EPA), and the Division of Oil and Gas (DOG). Pacific Gas and Electric Company has also been active in development of abatement technology in support of continued development at The Geysers. NSF funded $\$ 2$ million in this area in FY'75; all of the ongoing NSF programs are supported by this funding. ERDA funded $\$ 158$ thousand in FY'75, \$1.38 million in FY'76 (including the transition quarter), and has requested $\$ 2.0$ million in FY'77. 
Táble 6-4. ERDA R\&D programs for improvement of conversion technology *

NOTE: Unless otherwise indicated, programs are funded by ERDA.

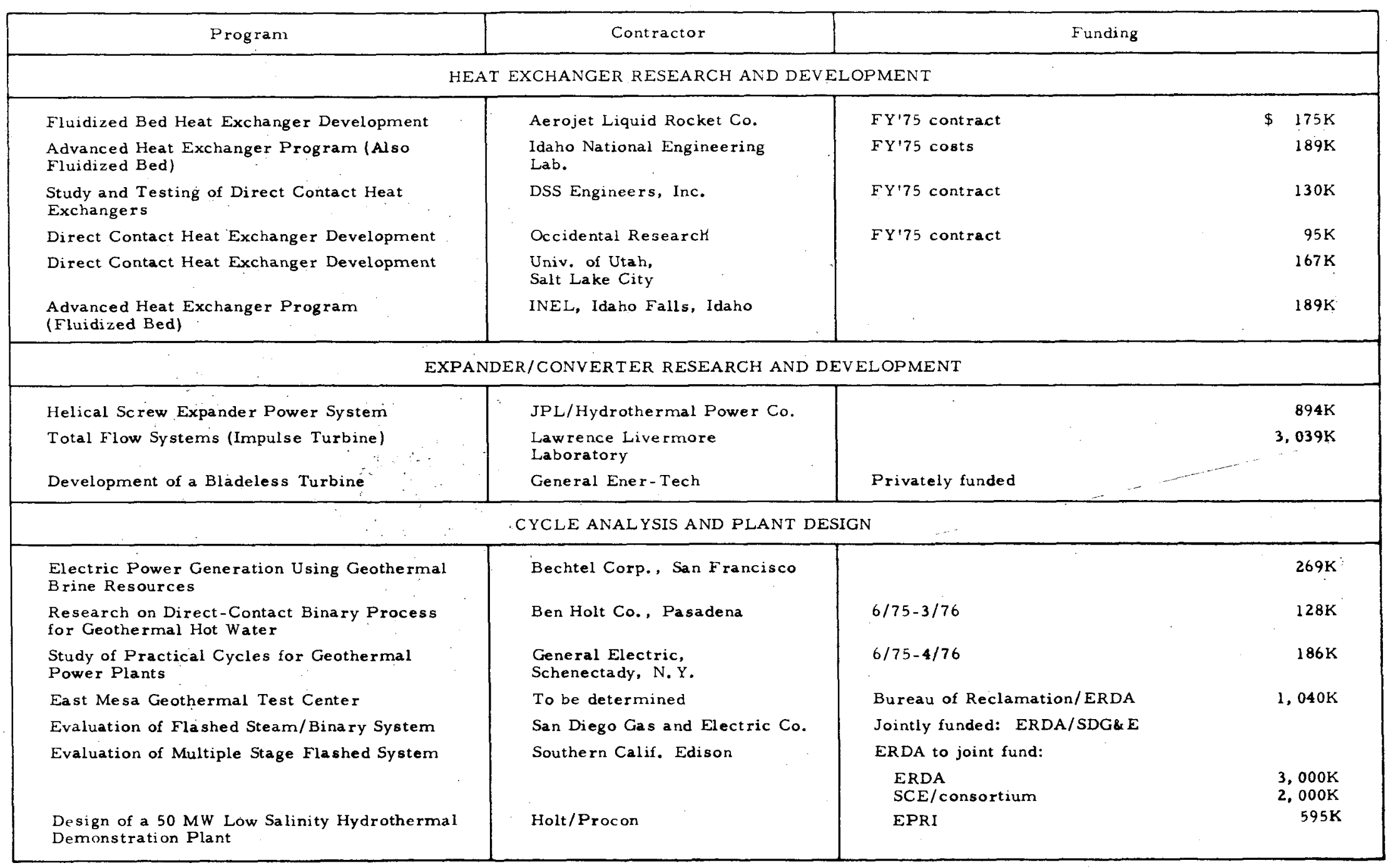

*For additional conversion technology programs see Table 6-6. 
On-going programs in the various categories, and their sponsors, are shown in Table 6-5.

\section{LEGAL AND INSTITUTIONAL STUDIES}

It is axiomatic within the geothermal community that legal and institutional is sues are primary impediments to more rapid geothermal development. Such issues include present federal leasing and tax policies, questions of ownership of subsurface rights with respect to geothermal deposits, environmental regulatory procedures and jurisdictional authority of the numerous regulatory bodies, procedures and criteria for establishing utility rate bases and associated capital formation problems, land-and water-use conflicts, and similar issues. Changes in the present legal and institutional environment could have broad impact on the community at large, but can be undertaken only after careful analysis of the relative costs and benefits involved in the various policy alternatives that have been proposed to facilitate geothermal development. Studies in this area were initiated by NSF in FY'75; ERDA has now taken over responsibility for this effort. The ERDA budget for policy analysis in FY'76 is $\$ 1.0$ million, and $\$ 1.5$ million has been requested for FY'77. The California Energy Resources Conservation and Development Commission has also budgeted $\$ 270 \mathrm{~K}$ in $\mathrm{FY}^{\prime} 76 / 77$ to support studies in this area.

Ongoing efforts include:

\begin{tabular}{|l|l|l|c|}
\hline \multicolumn{1}{|c|}{ Program } & \multicolumn{1}{|c|}{ Sponsor } & \multicolumn{1}{|c|}{ Contractor } & Funding \\
\hline $\begin{array}{l}\text { Legal and Institutional Barriers } \\
\text { to Geothermal Development }\end{array}$ & ERDA & $\begin{array}{l}\text { Univ. of So. } \\
\text { Calif. }\end{array}$ & \\
$\begin{array}{l}\text { Legal and Institutional Barriers } \\
\text { in California }\end{array}$ & ERDA & $\begin{array}{l}\text { Battelle Human } \\
\text { Resources Ctr. } \\
\text { Seattle }\end{array}$ & $\$ 75 \mathrm{~K}$ \\
\hline
\end{tabular}

PLANNING EFFORTS AND ECONOMIC STUDIES

In view of the local nature of geothermal development, there is a recognized need for planning studies to allow communities to evaluate the local impact of such development, and for economic studies to provide industry the 
Table 6-5. R\&D programs to identify, evaluate, and ameliorate the environmental effects of geothermal development*

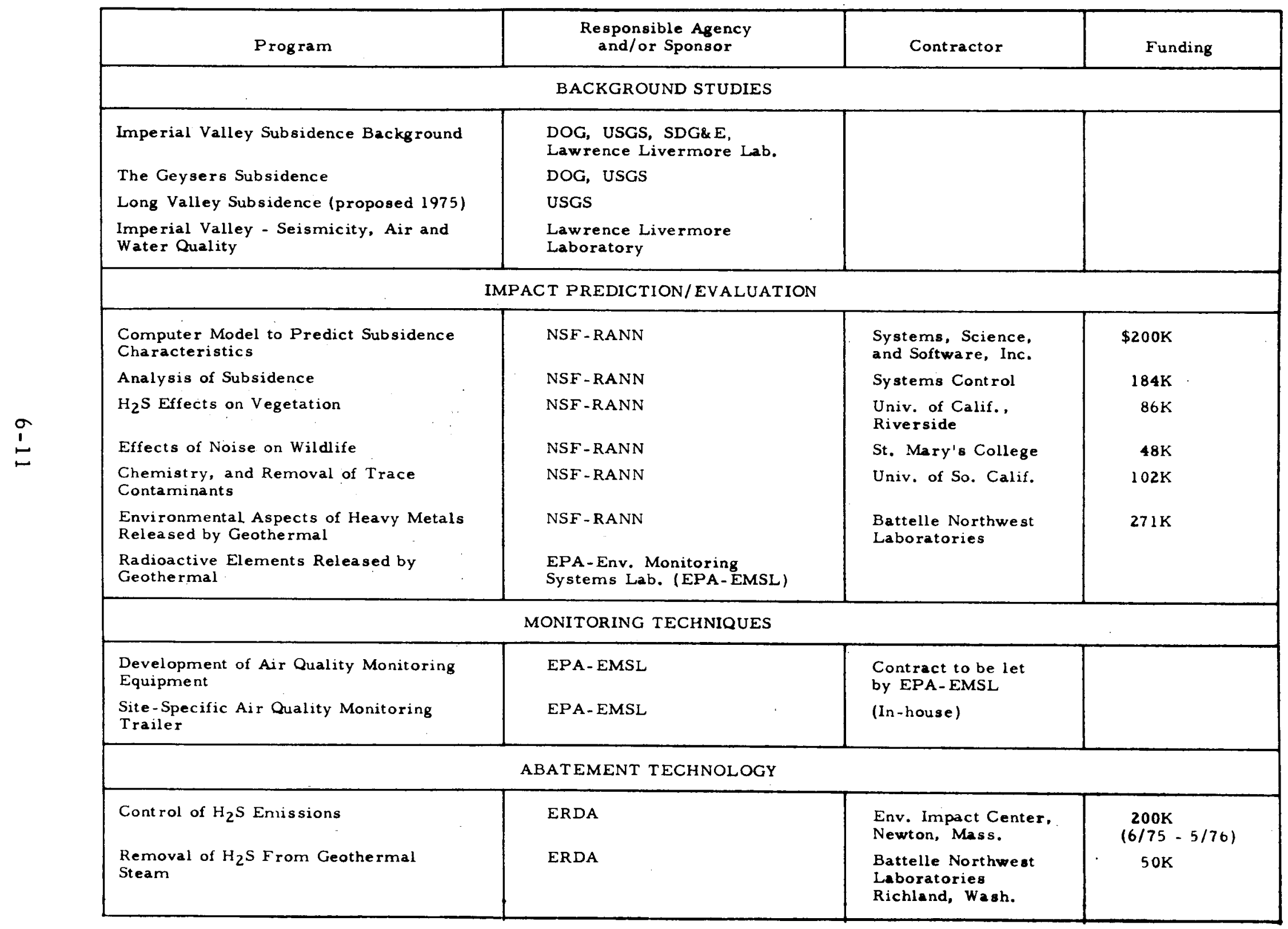

\footnotetext{
* For additional environmental programs see Table 6-7.
} 
tools with which to evaluate the relative profitability of geothermal investment. Efforts in these areas were initiated by NSF (planning) and AEC (economic modeling) in 1975, and have been continued by ERDA. The major ongoing efforts include:

\begin{tabular}{|l|l|l|c|}
\hline \multicolumn{1}{|c|}{ Program } & Sponsor & \multicolumn{1}{|c|}{ Contractor } & Funding \\
\hline Susanville Project & ERDA & $\begin{array}{l}\text { Susanville/ } \\
\text { VTN/Calif. } \\
\text { State Lands } \\
\text { Commission }\end{array}$ & $\begin{array}{l}\$ 300 \mathrm{~K} \\
(6 / 75-8 / 76)\end{array}$ \\
$\begin{array}{l}\text { Systems Analysis (Economic } \\
\text { Modeling) }\end{array}$ & ERDA & $\begin{array}{l}\text { Battelle } \\
\text { Northwest Labs. } \\
\text { Imperial Valley Planning Grant }\end{array}$ & NSF/ERDA \\
$\begin{array}{l}\text { Regional Operations Resources } \\
\text { for Geothermal Development in } \\
\text { California }\end{array}$ & $\begin{array}{l}\text { CERCDC/ } \\
\text { ERDA }\end{array}$ & $\begin{array}{l}\text { JPL, Stamford } \\
\text { Research Inst. }\end{array}$ & $\$ 389 \mathrm{~K}$ \\
\hline
\end{tabular}

In addition, CERCDC has budgeted $\$ 140 \mathrm{~K}$ for the preparation of community selfhelp manual for planning for geothermal development.

\section{ADDENDUM}

As the result of the review of this report additional $R \& D$ programs have been identified and are presented in Tables $6-6$ and 6-7. 
Table 6-6. Additional conversion and materials technology programs

\begin{tabular}{|c|c|c|c|}
\hline Program & $\begin{array}{c}\text { Responsible } \\
\text { Agency/Organization }\end{array}$ & Contractor & Funding \\
\hline Heat exchanger research & ERDA & $\begin{array}{l}\text { Lawrence Berkeley } \\
\text { Laboratory }\end{array}$ & $\$ 272 \mathrm{~K}$ \\
\hline $\begin{array}{l}\text { Tube in shell counterflow heat exchange } \\
\text { tests }\end{array}$ & EPRI & $\begin{array}{l}\text { SDG\&E, and the } \\
\text { Ben Holt Co. }\end{array}$ & $\$ 180 \mathrm{~K}$ \\
\hline $\begin{array}{l}\text { Brime chemistry and heat / mass transfer } \\
\text { studies }\end{array}$ & EPRI & Battelle Northwest & $\$ 450 \mathrm{~K}$ \\
\hline $\begin{array}{l}\text { Design of mobil geothermal fluids, } \\
\text { materials and component test laboratory }\end{array}$ & EPRI & --- & $\$ 200 \mathrm{~K}$ \\
\hline
\end{tabular}


Table 6-7. Additional environmental programs

\begin{tabular}{|c|c|c|c|}
\hline Program & $\begin{array}{c}\text { Responsible } \\
\text { Agency/Organization }\end{array}$ & Contractor & Funding \\
\hline $\begin{array}{l}\text { Geysers vegetation - mapping for computer } \\
\text { analysis }(6-5)\end{array}$ & PG\&E/Union Oil & COMRAC & $\$ 40 \mathrm{~K}$ \\
\hline $\mathrm{H}_{2} \mathrm{~S}$ monitoring & PG\&E & & \\
\hline Automated $\mathrm{H}_{2} \mathrm{~S}$ air monitoring network & $\begin{array}{l}\text { PG\&E/Union Oil/ } \\
\text { Pacific Energy/ } \\
\text { Burmah Oil }\end{array}$ & SRI & $\begin{array}{l}\$ 700 \mathrm{~K} \\
(2 \mathrm{yrs})\end{array}$ \\
\hline Evaluation of Geysers KGRA Fisheries & PG\&E & --- & --- \\
\hline Wildlife effects & PG\&E/Union Oil & --- & --- \\
\hline $\begin{array}{l}\text { Investigations of the release of Radon, its } \\
\text { daughters and possible precursors at the } \\
\text { Geysers }\end{array}$ & PG\&E/ Union Oil & $\begin{array}{l}\text { Lawrence } \\
\text { Livermore Labs }\end{array}$ & $\$ 150 \mathrm{~K}$ \\
\hline $\begin{array}{l}\text { Environmental baseline data acquisition - } \\
\text { HEBER }\end{array}$ & EPRI & SDGE & $\$ 140 \mathrm{~K}$ \\
\hline $\begin{array}{l}\text { Biological problems of geothermal } \\
\text { development on fish and wildlife }\end{array}$ & $\begin{array}{l}\text { U. S. Fish and } \\
\text { Wildlife Service }\end{array}$ & $\begin{array}{l}\text { Jones \& Stokes } \\
\text { Associates }\end{array}$ & $\$ 80 \mathrm{~K}$ \\
\hline $\begin{array}{l}\text { Program development of biological base- } \\
\text { line criteria and monitoring techniques }\end{array}$ & $\begin{array}{l}\text { U. S. Fish and } \\
\text { Wildlife Service, } \\
\text { Western Energy and } \\
\text { Land Use Team }\end{array}$ & In-house & \\
\hline
\end{tabular}

